\title{
Parque urbano: aplicação do Sistema Nacional de Unidades de Conservação (SNUC) ao meio ambiente urbano
}

José Eduardo Ramos Rodrigues

Tese apresentada ao Programa de PósGraduação em Saúde Pública da Faculdade de Saúde Pública da Universidade de São Paulo para obtenção do título de Doutor em Saúde Pública.

Área de Concentração: Saúde Ambiental

Orientador: Prof. Dr. Arlindo Philippi Jr

\section{São Paulo}

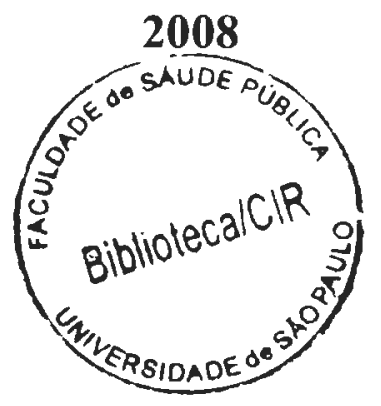


É expressamente proibida a comercialização deste documento, tanto na sua forma impressa como eletrônica. Sua reprodução total ou parcial é permitida exclusivamente para fins acadêmicos e cientificos, desde que na reprodução figure a identificação do autor, título, instituição e ano da tese.

$$
50459 / 2009 \text { die }
$$


$\grave{A}$ amiga Raquel (in memoriam) 


\section{AGRADECIMENTOS}

Ao Professor Doutor Arlindo Philippi Júnior, cuja orientação segura e incentivo constante foram primordiais para que se concretizasse esta tese.

Ao Professor Doutor Celso Fernandes Campilongo, cuja co-orientação enriqueceu sobremaneira este trabalho, especialmente em seus aspectos jurídicos.

Aos Professores Doutores Sueli Gandolfi Dallari, Guilherme Purvin de Figueiredo e Vladimir Passos de Freitas, integrantes da banca examinadora, por suas valiosas sugestões que muito aprimoraram esta tese.

Aos Diretores José Amaral Wagner Neto e José Carlos Geraci, da Fundação para a Conservação e a Produção Florestal do Estado de São Paulo, por seu inestimável apoio e incentivo institucional.

Ao colega advogado Itacyr Pastorelo, prezado amigo e incentivador.

À Professora Doutora Patrícia Pizarro Werner, por suas importantes sugestões de conteúdo e estrutura.

Aos pesquisadores Juliana Ribeiro, Márcia Rebouças, Mauro Victor e Régis Guillaumont que gentilmente colocaram suas obras, documentos, dados e informações a minha disposição para pesquisa.

Ao nobre advogado Durvalino Picolo, que colocou a estrutura de seu escritório à minha disposição.

À estagiária Cibelle Ferraz, por seu valioso auxílio na pesquisa e revisão.

À advogada Dayana Uhdre, às Senhoras Lucimara Barbosa, Lílian van Enck, Vanda Arakian e Marilene Gonzalez, pelo imprescindível apoio na execução. 
RODRIGUES, J. E. R. Parque urbano: aplicação do Sistema Nacional de Unidades de Conservação (SNUC) ao meio urbano. [tese de doutorado]. São Paulo: Faculdade de Saúde Pública da USP; 2008.

Este trabalho tem por objetivo demonstrar que o rol de unidades de conservação do Sistema Nacional de Unidades de Conservação (SNUC) na verdade não é exaustivo. É possível observar-se outras categorias de unidades de conservação federais. Estados, Municípios e Distrito Federal também têm competência constitucional para criar, mediante leis próprias, categorias de unidades de conservação em sentido amplo, distintas daquelas do SNUC, que podem ser sistematizadas ou não. Inclusive, tais categorias próprias podem ser voltadas para o meio urbano, até porque os Estados, Municípios e Distrito Federal estarão exercendo sua competência constitucional supletiva, eis que o SNUC tratou apenas da preservação no âmbito rural. Apesar da divergência em torno dos conceitos de "urbano" e "rural", nada impede a criação de unidades de conservação integral em área urbana. A preservação do verde é essencial para a qualidade de vida das populações residentes nas cidades. Dai ser fundamental a aplicação ao parque urbano do regime jurídico próprio das unidades de conservação com a finalidade de garantir a sua proteção e o exercício adequado de suas funções sócio-ambientais no meio ambiente artificial. Assim poderão ser evitados ou sensivelmente reduzidos problemas graves, do tipo daqueles historicamente sofridos pelos Parques da Luz, Tenente Siqueira Campos, da Aclimação e do Ibirapuera, como perdas de área e descaracterização de uso.

Descritores: Direito ambiental; Conservação; Unidades de Conservação; Sistema Nacional de Unidades de Conservação; Cidades; Saúde; Parques urbanos. 


\section{RODRIGUES, J. E. R. Urban park: application of the National System of}

Protected Areas (SNUC) in urban areas.[thesis doctor]. São Paulo: Faculdade de Saúde Pública da USP; 2003.

\section{ABSTRACT}

This work has the aim of demonstrating that the list of the National System of Protected Areas (SNUC) in fact, isn't exhausting. It's possible to observe other categories of federal protected areas. States, Cities and Federal District also have constitutional competence to create, according to proper laws, categories of protected areas in a wide sense, different from the ones of the SNUC, that can be systemized or not. Inclusively, such proper categories can be for urban areas, because States, Cities and Federal District are executing their supplementary constitutional competence; the SNUC has only treated the conservation in the rural sphere of action. In spite of the disagreement about the concepts of "urban" and "rural", nothing impedes the creation of integral protected areas in urban areas. The conservation of the green is essential for the quality of life of the people who lives in cities. So it's of fundamental importance the application of proper juridical regime of protected areas to urban parks, with the aim of guaranteeing their protection and the adequate execution of their social and environmental functions in an artificial environment. So serious problems can be avoided or sensibly reduced, like the ones historically suffered by Parque da Luz, Tenente Siqueira Campos, Aclimação and Ibirapuera, such as lost of areas and removal of their characteristic use.

Descriptors: Environmental Law; Conservancy; National System of Protected Areas; Cities; Health; Urban Parks. 


\section{ÍNDICE}

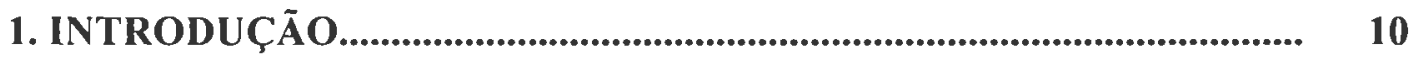

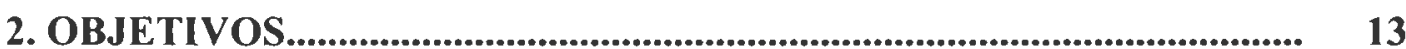

2.1.OBJETIVO GERAL .................................................................. 13

2.2.OBJETIVOS ESPECÍFICOS .......................................................... 13

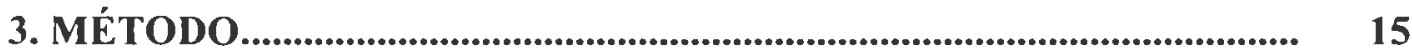

3.1. LEVANTAMENTO DE DADOS................................................ 15

3.2. LOCAIS DE PESQUISA DE DADOS......................................... 16

3.3. ORGANIZAÇÃO E ANÁLISE DE DADOS ................................... 16

3.4. RESULTADOS E POSSIVEIS PRODUTOS................................... 16

4.DISCUSSÃO.................................................................................................... 17

4.1 SISTEMA NACIONAL DE UNIDADES DE CONSERVAÇÃO 17 (SNUC).

4.1.1. Unidades de proteção integral............................................. 20

4.1.1.1. Estação ecológica................................................. 20

4.1.1.2. Reserva biológica................................................ 21

4.1.1.3. Parque nacional..................................................... 21

4.1.1.4. Monumento natural............................................. 22

4.1.1.5. Refúgio da vida silvestre.................................... 22

4.1.2. Unidades de uso sustentável............................................... 23

4.1.2.1. Área de proteção ambiental.................................. 23

4.1.2.2. Área de relevante interesse ecológico................... 24

4.1.2.3. Floresta nacional................................................... 24

4.1.2.4. Reserva extrativista.............................................. 25

4.1.2.5. Reserva de fauna................................................. 26

4.1.2.6. Reserva de desenvolvimento sustentável............. 26

4.1.2.7. Reserva particular do patrimônio natural.............. $\quad 27$

4.1.3. Reserva da biosfera........................................................... 28 
4.1.4. Criação e gestão das unidades de conservação

4.2. AUTONOMIA DAS UNIDADES FEDERADAS PARA CRIAÇÃO DE UNIDADES DE CONSERVAÇÃO INTEGRANTES DO SNUC.

4.3. AUTONOMIA DAS UNIDADES FEDERADAS PARA CRIAR UNIDADES DE CONSERVAÇÃO FORA DO SNUC................. 39

4.3.1. Unidades de conservação federais em sentido amplo.......... 40

4.3.2. Unidades de conservação estaduais e distritais em sentido amplo: sistemas estaduais de unidades de conservação......

4.3.2.1. Categorias de unidades de conservação independentes do SNUC por Estado.

4.3.2.2. Sistemas estaduais de unidades de conservação...

4.3.2.3. Sistemas municipais de unidades de conservação

4.4. UNIDADES DE CONSERVAÇÃO DE PROTEÇÃO INTEGRÁL COMO ZONA RURAL: SIGNIFICADO.

4.4.1. Conceitos de zona rural e zona urbana.

4.4.2. Conceitos de urbano e rural do ponto de vista das ciências não jurídicas

4.4.3. Conceitos de urbano e rural no ordenamento jurídico brasileiro.

4.4.4. Relação entre lei complementar e lei ordinária..

4.4.5. Significado de zona rural e zona urbana para a Lei do SNUC .

4.5.1. Visão ecossistêmica e social da cidade.

4.5.2. Estatuto da cidade

4.5.3. Cidades saudáveis e qualidade de vida.

4.5.4. Vegetação e qualidade de vida urbana.

4.5.4.1. Benefícios físicos e biológicos

4.5.4.1.1. Mudanças microclimáticas.

4.5.4.1.2. Conservação de energia e dióxido de carbono.

4.5.4.1.3. Remoção de contaminantes do ar. 
4.5.4.1.4. Hidrologia urbana.

4.5..4.1.5. Redução do ruído......................................... 123

4.5.4.1.6 Benefícios ecológicos............................... 124

4.5.4.2. Benefícios socioeconômicos................................ 125

4.5.4.2.1. Beneficios econômicos de ambientes agradáveis.

4.5.4.2.2. Saúde mental e física

4.5.4.2.3. Valorização da propriedade.

4.5.4.2.4. Desenvolvimento econômico local.............. 128

4.5.4.2.5. Beneficios sociais................................. 128

4.5.5. Indicadores de vegetação urbana..................................... 131

4.5.6. Indicadores de verde urbano em São Paulo......................... 134

.6. PARQUES URBANOS.......................................................... 137

4.6.1. Conceitos de parque urbano.......................................... 137

4.6.2. Parques urbanos através da história.................................. 151

4.6.3. Parques urbanos paulistanos e sua história......................... 173

4.6.4. Parques urbanos e o plano diretor da cidade de São Paulo.. 187

.7. ESTUDOS DE CASO: PARQUES DA LUZ, TENENTE SIQUEIRA CAMPOS (TRIANON), DA ACLIMAÇÃO E DO IBIRAPUERA.

4.7. I. Parque da Luz

4.7.1.1. Origens: Horto ou Jardim Botânico.

4.7.1.2. Jardim Público a partir de 1838

4.7.1.3. Municipalização na República.

4.7.1.4. Decadência a partir da década de 1930.

4.7.1.5. Revitalização e situação atual............................. 210

4.7.1.6. Problemas observados....................................... 2II

4.7.2. Parque Tenente Siqueira Campos (Parque do Trianon: denominação popular.

4.7.3. Parque da Aclimação 


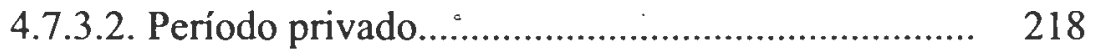

4.7.3.3. Periodo público.............................................. 221

4.7.3.4. Problemas observados...................................... 226

4.7.4. Parque do Ibirapuera...................................................... 228

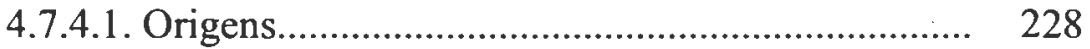

4.7.4.2. Implantação do Viveiro Manequinho Lopes........ 235

4.7.4.3. Primeiros projetos paisagísticos......................... 237

4.7.4.4. Exposição do IV Centenário................................ 242

4.7.4.5. Decadência e descaracterização........................... 246

4.7.4.6. Melhorias a partir da década de 1970: situação atual........................................................ 250

4.7.4.7. Problemas observados...................................... 259

4.7.5. Síntese dos problemas encontrados nos parques analisados 261

4.8. PARQUE URBANO COMO UNIDADE DE CONSERVAÇÃO.. 262

4.8.1. Conceito …………...................................................... 262

4.8.2. Regime jurídico......................................................... 270

4.8.2.1. Conselho gestor.............................................. 270

4.8.2.2. Plano de manejo............................................. 277

4.8.2.3. Zona de amortecimento e corredores ecológicos. $\quad 284$

4.8.2.4. Gestão compartilhada....................................... 288

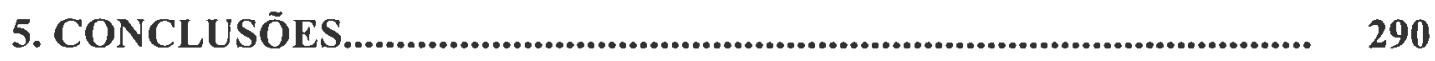

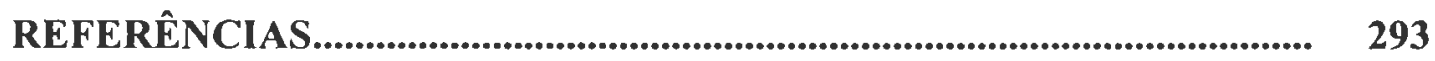




\section{INTRODUÇÃO}

Tendo por ponto de partida o Sistema Nacional de Unidades de Conservação (SNUC), este trabalho resulta da reflexão sobre a necessidade de maior aprofundamento nesse tema, especialmente no que tange a aspectos relevantes não explicitados ou simplesmente olvidados pelo texto legal (Lei 9.985, de 18 de Julho de 2000, Lei do SNUC).

Assim, embora no SNUC a União tenha elaborado normas gerais com a finalidade, até certo ponto, de abarcar as unidades de conservação das demais esferas federativas, continua possivel, do ponto de vista constitucional, a criação pelos Estados, Municípios e Distrito Federal de sistemas próprios, adequados às suas peculiaridades.

Além disso, o conceito legal da unidade de conservação (art. $2^{\circ}$, inc. I, da Lei 9.985 de 18/07/2000) é suficientemente amplo para permitir a inclusão de outras categorias de unidades existentes em nosso país. Isto faz presumir que o legislador optou por arrolar especialmente algumas categorias de unidades no SNUC, mas não condenou as demais à ilegalidade, inclusive algumas também federais, que continuam existentes, e aquelas específicas de Estados, Municípios e do Distrito Federal.

Destarte, temos unidades de conservação tradicionais, como os jardins botânicos e jardins zoológicos, não incluidos no SNUC. A própria Lei do SNUC menciona a reserva da biosfera, sem incluí-la seja no grupo de unidades de proteção integral, seja naquele de unidades de desenvolvimento sustentável.

Neste trabalho foi feito um levantamento de legislações estaduais, municipais e também da distrital. Tem este a finalidade de verificar se os Estados, 
Municípios e Distrito Federal estão exercendo as suas competências constitucionais na criação de unidades de conservação estaduais, municipais e distritais próprias, organizadas em sistemas, ou não. Isto é, que não se resumam à cópia servil das categorias de unidades de conservação do SNUC.

Por outro lado, o SNUC adotou uma postura excessivamente rural, de forma a deixar de lado os ecossistemas urbanos, de fundamental importância para a sociedade brasileira, na medida em que a maioria da população neles habita. Tanto que a lei do SNUC expressamente declarou como áreas rurais aquelas ocupadas por unidades de conservação, sem levar em conta suas reais características de ocupação, nem a definição de urbano ou rural. Aparentemente a Lei do SNUC apenas ampliou a . confusão legal já existente em torno dos conceitos de "área urbana” e "área rural”.

Salvo situações não desejadas, ém que unidades de conservação como o Parque Nacional da Floresta da Tijuca, no Rio de Janeiro, ou o Parque Estadual da Cantareira, em São Paulo, a título de exemplo, viram-se. envolvidos pelo tecido urbano em crescimento desordenado (que põe em risco a biodiversidade e a existência dessas unidades), as categorias do SNUC estão distanciadas das áreas urbanas. A lei não levou em conta a importância de se implantar "unidades de conservação urbanas" específicas, entre as quais se destacam os parques urbanos.

Os parques urbanos são de notável importância para as cidades, contribuindo para a melhoria da qualidade do ar, redução da poluição sonora, preservação da fauna e flora urbana, amenização dos efeitos das "ilhas de calor", além de servir de agradáveis espaços para o lazer da população. É importante cuidar da sua preservação.

É possivel aos Sistemas Estaduais de Unidades de Conservação, o Distrital e, principalmente, os Municipais, suprir tais omissões da legislação federal, com fundamento na Constituição Federal e na própria Lei do SNUC. 
No que tange a parques urbanos, a incorporação de princípios do SNUC, como a participação da sociedade civil em conselhos das unidades, a obrigatoriedade de plano de manejo, a criação de zonas de amortecimento, a possibilidade de gestão compartilhada com organizações sociais, entre outros, seria de imensa utilidade no sentido de se preservar essas áreas verdes de importância fundamental para o bem estar físico, social e psicológico das populações urbanas. Inclusive, contribuiriam para frear as constantes descaracterizações de uso, reduções de área, ausência de conservação, infelizmente tão associadas aos parques urbanos, resultantes de interesses políticos passageiros totalmente dissociados do bem comum.

Para ilustrar os problemas típicos dos parques urbanos, vamos analisar neste trabalho a história de quatro parques urbanos municipais tradicionais da cidade de São Paulo: Luz, Tenente Siqueira Campos (Trianon), Aclimação e Ibirapuera.

Pretende-se demonstrar ao final, que o tratamento dos parques urbanos como unidades de conservação em sentido amplo, isto é, ainda que não integrantes do SNUC, porém seguindo os princípios inscritos neste sistema, pode resultar em grandes vantagens para a sua preservação e em importantes benefícios para a numerosa população urbana brasileira. 


\section{OBJETIVOS}

\subsection{OBJETIVO GERAL}

Comprovar a possibilidade legal de criação de sistemas estaduais e municipais de unidades de conservação, com categorias distintas daquelas do sistema nacional de unidades de conservação, cuja implantação seria não apenas legalmente possivel, mas também útil, com repercussão positiva para o meio ambiente, a saúde e a qualidade da vida humana. Seria possível então a criação de novas categorias de unidades de conservação que fossem voltadas às peculiaridades das unidades federativas, especialmente aquelas voltadas à proteção do meio ambiente urbano onde vive a maior parte da população brasileira.

\subsection{OBJETIVOS ESPECÍFICOS}

a) Alargar a aplicação dos princípios que regem o sistema nacional de unidades de conservação.

b) Contribuir para tornar mais efetivo o papel da unidade de conservação na proteção de valores urbanos e culturais, que também são ambientais, como também na melhoria da saúde e da qualidade da vida humana, especialmente dentro das cidades; 
c) Estimular a iniciativa dos estados e municípios na busca de soluções para a preservação ambiental dentro de suas respectivas esferas de atuação;

d) Alargar a bibliografia crítica sobre o tema, ainda muito restrita, especialmente entre os autores jurídicos brasileiros. 


\section{MÉTODO}

Por tratar-se aqui de pesquisa em área de ciências humanas, não cabe aqui a utilização do método de observação-experimentação, mas sim do método de explicação e compreensão do sentido dos fatos humanos, buscando sua casualidade histórico-cultural (CHAUí, 2003, p.228).

Uma vez que esta tese busca construir o conhecimento compartilhado pelo diálogo interdisciplinar, também utilizamos o método dialógico, o qual parte da evidência de que não existe uma verdade estanque e pondera sobre diversos conhecimentos adquiridos para construir convenções transitórias úteis ao conhecimento e à aplicação (BITTAR, 2007, p.18).

\subsection{LEVANTAMENTO DE DADOS}

O trabalho baseia-se em dados originários de fontes secundárias, a serem obtidos através do levantamento de:

a) Bibliografia (livros, artigos, anais de eventos, dissertações de mestrado, teses de doutorado, trabalhos na internet e outros) que contenham doutrina jurídica referente a unidades de conservação e meio ambiente natural e urbano, anterior ou posterior ao SNUC, tanto brasileira quanto estrangeira; 
b) Levantamento da bibliografia não jurídica, voltada à área ambiental natural e urbana, tanto brasileira quanto. estrangeira, com o fim precípuo de dar suporte à jurídica.

\subsection{LOCAIS DE PESQUISA DE DADOS}

A pesquisa dos dados será efetuada em sites selecionados da internet, jornais e nos acervos bibliográficos pertencentes a instituições públicas e privadas com atuação ligada aos objetivos do trabalho.

\subsection{ORGANIZAÇÃO E ANÁLISE DE DADOS}

Após efetuado o levantamento de dados, passaremos a selecionar e fichar aqueles dentro desse universo que tenham relacionamento com o tema.

\subsection{RESULTADOS E POSSÍVEIS PRODUTOS}

A partir deste trabalho pretende-se elaborar os seguintes produtos:
a) Artigos;
b) Relatórios;
c) Outras publicações 


\section{DISCUSSÃO}

\subsection{SISTEMA NACIONAL DE UNIDADES DE CONSERVAÇÃO (SNUC)}

Espaços territoriais especialmente protegidos são aqueles instituídos por ato normativo específico do poder público, em razão da necessidade de proteger determinado ecossistema dotado de peculiaridades e atributos, nos termos do artigo 222 , $\$ 1^{\circ}$, inc III, da Constituição Federal. Nesses casos, as florestas e demais formas de vegetação só poderão ser utilizadas e exploradas desde que não se contrariem as disposições do Código Florestal e não se comprometam os atributos que justifiquem a especial proteção desses espaços, observadas as disposições pertinentes ao seu regime jurídico estabelecido por ato normativo específico (RODRIGUES, 2005a, p.333).

Ao contrário dos espaços territoriais especialmente protegidos, definidos na própria constituição, as unidades de conservação, embora reguladas por diplomas especiais, não tinham uma verdadeira definição legal. A Resolução CONAMA n 11 de 03/12/1987, por exemplo, limitou-se a elencar algumas categorias de espaços protegidos, denominando-os unidades de conservação sem qualquer justificativa. Até mesmo a Lei 9.605, de 12 de fevereiro de 1998 (Crimes Ambientais), em seu artigo $40, \S I^{\circ}$, na redação original, informava genericamente serem unidades de conservação as reservas biológicas, estações ecológicas, parques nacionais, estaduais e municipais, florestas nacionais, estaduais e municipais, áreas de proteção ambiental, áreas de relevante interesse ecológico e reservas extrativistas ou outras a serem criadas pelo poder público, sem oferecer qualquer definição a respeito. Isto permitia à doutrina elaborar conceitos dos mais variados, sem nenhuma conclusão definitiva (RODRIGUES, 2005a, p.333-334) 
Porém, em 18 de julho de 2000, foi promulgada a Lei 9.985, que cria o Sistema Nacional de Unidades de Conservação (Lei do SNUC). Surgiu então a definição de unidade de conservação, entendida como espaço territorial e seus recursos ambientais, incluindo as águas jurisdicionais, com características naturais relevantes, legalmente instituídas pelo Poder Público, com objetivos de conservação e limites definidos, sob o regime especial de administração, ao qual se aplicam garantias adequadas de proteção (inc. I do art. $2^{\circ}$ da Lei do SNUC).

A estrutura do Sistema Nacional de unidades de Conservação (SNUC) compreende os seguintes órgãos (art. $6^{\circ}$, incs. I a III):

I- Órgão consultivo e deliberativo: o Conselho Nacional do Meio Ambiente (CONAMA), ao qual cabe acompanhar a implantação do sistema;

II- Órgão central: o Ministério do Meio Ambiente, coordenador do sistema;

III- Órgãos executores: o Instituto Chico Mendes de Conservação e Biodiversidade (criado pela Lei 11.516 de 28/08/2007), os órgãos ambientais estaduais e municipais, a quem cabe implementar o SNUC, subsidiar as propostas de criação e administrar as unidades de conservação nas respectivas esferas de atuação. Embora a lei não mencione, por erro técnico, deve ser incluído entre os órgãos executores o órgão ambiental do Distrito Federal (RODRIGUES, 2005a, p.334).

As unidades de conservação integrantes do SNUC dividem-se em dois grupos (art. $7^{\circ}$, incs. I e II da lei do SNUC):

I- Unidades de Proteção Integral;

II- Unidades de Uso Sustentável; 
As unidades de proteção integral são aquelas destinadas a preservar a natureza, sendo admitido apenas o uso indireto, isto é, aquele que não envolve consumo, coleta, dano ou destruição dos recursos naturais. Incluem as seguintes categorias (art. $8^{\circ}$ incs. I aV):

I- Estação ecológica:

II- Reserva biológica;

III- Parque nacional:

IV-Monumento natural;

V- Refúgio da vida silvestre.

As unidades de uso sustentável são aquelas destinadas a compatibilizar a conservação da natureza com o uso sustentável, isto é, aquele que implica a exploração do ambiente de maneira a garantir a perenidade dos recursos ambientais renováveis e dos processos ecológicos, mantendo a biodiversidade e os demais atributos ecológicos, de forma socialmente justa e economicamente viável. Incluem as seguintes categorias (art. 14, incs. I a VII):

I- Áreas de proteção ambiental;

I1- Área de relevante interesse ecológico;

III- Floresta nacional;

IV-Reserva extrativista;

V- Reserva de fauna;

VI-Reserva de desenvolvimento sustentável

VII- Reserva particular do patrimônio natural. 
A integração ao SNUC de categorias de unidades de conservação estaduais e municipais que não se enquadrem nas categorias acima somente poderá ocorrer em caráter excepcional, por deliberação do CONAMA (art. $6^{\circ}$, $\S$ único do SNUC).

\subsubsection{Unidades de proteção integral}

\subsubsection{Estação ecológica}

Área de posse e domínio público que tem por objetivo a preservação da natureza e a realização de pesquisas científicas. A visitação pública é proibida, exceto com o objetivo educacional, de acordo com o que dispuser o plano de manejo. A pesquisa científica depende de autorização previa do órgão responsável pela sua administrạ̧ão (art. $9^{\circ} \mathrm{e} \S \S$ da Lei do SNUC).

Plano de manejo é definido pelo SNUC como sendo um documento técnico mediante o qual, com fundamento nos objetivos gerais de uma unidade de conservação, se estabelecem as zonas ou setores e respectivos usos neles permitidos, como também o manejo dos recursos naturais, inclusive a implantação das estruturas físicas necessárias à gestão da unidade. Por sua vez, manejo é todo procedimento que vise assegurar a conservação da diversidade biológica e dos ecossistemas (inc. XVII do art. $2^{\circ}$ ). 


\subsubsection{Reserva biológica}

Área de posse e domínio público que tem por objeto a preservação integral da biota e demais atributos naturais existentes em seus limites, sem interferência humana ou modificações ambientais, excetuando-se as medidas de recuperação de seus ecossistemas alterados e as ações de manejo necessárias para recuperar o equilibrio natural, a diversidade biológica e os processos ecológicos naturais. A visitação é proibida, exceto com o objetivo educacional. A pesquisa científica depende de autorização prévia do órgão responsável pela administração da unidade (art. 10 e $\$ \$)$.

\subsubsection{Parque nacional}

Área de posse e domínio público que tem por objetivo a preservação de ecossistemas naturais de grande relevância ecológica e beleza cênica, possibilitando a pesquisa científica, atividades de educação ambiental, de recreação em contato com a natureza e turismo ecológico. A visitação pública esta sujeita às normas do plano de manejo. A pesquisa científica depende de autorização prévia do órgão administrador da unidade (art. 11 e $\S \S)$. 


\subsubsection{Monumento natural}

Área que tem por objetivo preservar sítios naturais raros, singulares ou de grande beleza cênica. Seu domínio pode ser particular desde que haja compatibilidade entre os objetivos da unidade com o uso que lhe for dado pelo proprietário. Caso contrário, a área deverá ser desapropriada. A visitação pública esta sujeita às regras estabelecidas no plano de manejo e às normas estabelecidas pelo órgão administrador da unidade (art. 12 e $\S$ ).

4.1.1.5. Refúgio da vida silvestre

Área que tem por objetivo proteger ambientes naturais onde se assegurem condições para a existência ou reprodução de espécies ou comunidades da flora local e da fauna residente ou migratória. Seu domínio pode ser particular desde que haja compatibilidade entre os objetivos da unidade com o uso que lhe for dado pelo proprietário. Caso contrário, a área deverá ser desapropriada. A visitação pública está sujeita às regras estabelecidas no plano de manejo e às normas estabelecidas pelo órgão administrador da unidade, cuja autorização também é necessária para a realização de pesquisas científicas (art. 13 e $\S \S)$.

Cada unidade de conservação de proteção integral disporá de um conselho consultivo, presidido pelo órgão responsável por sua administração e constituido por representantes de órgãos públicos, entidades da sociedade civil, de proprietários de terras localizadas em refúgios da vida silvestre ou monumento natura, quando for caso, de populações tradicionais residentes, se existentes, enquanto não forem reassentadas fora da unidade (art. 29 da Lei do SNUC). 
4.1.2. Unidades de uso sustentável

4.1.2.1. Área de proteção ambiental

Área de domínio publico ou privado, em geral extensa, com um certo grau de ocupação humana, dotada de atributo abióticos, bióticos, estéticos ou culturais especialmente importantes para a qualidade de vida e o bem-estar das populações humanas, tendo como objetivos básicos proteger a diversidade biológicá, disciplinar o processo de ocupação e assegurar a sustentabilidade do uso dos recursos naturais. Nas áreas de domínio publico, as condições para a pesquisa e a visitação pública serão estabelecidas pelo gestor da unidade. No caso das áreas privadas, cabe ao proprietário estabelecer as normas para pesquisa e visitação, observadas as restrições legais (art. 15 e $\S \S 1^{\circ}$ a $4^{\circ}$ da Lei do SNUC).

Cada APA disporá de um conselho presidido pelo órgão responsável pela sua administração e constituído por representantes dos órgãos públicos, de organizações da sociedade civil e da população residente, conforme disposto no regulamento da Lei do SNUC ( $\$ 5^{\circ}$ do art. 15$)$. 
4.1.2.2. Área de relevante interesse ecológico

Área de domínio público ou privado, em geral de pequena extensão, com pouca ou nenhuma ocupação humana, com características naturais extraordinárias ou que abriga exemplares raros da biota regional, tendo como objetivo manter os ecossistemas naturais de importância regional ou local e regular o uso admissível dessa área, de modo a compatibilizá-lo com os objetivos de conservação da natureza (art. 16 e $\S \S)$.

\subsubsection{Floresta nacional}

Área de posse e domínio públicos, com cobertura vegetal de espécies predominantemente nativas, que tem como objetivo o uso múltiplo sustentável dos recursos florestais e a pesquisa cientifica, com ênfase em métodos para a exploração sustentável de florestas nativas. Nela admite-se a permanência de populações tradicionais que a habitam quando de sua criação, de acordo com as normas estabelecidas para o manejo da área. A pesquisa é permitida e incentivada, mediante previa autorização do órgão responsável pela sua administração (art. 17 e $\S \S 1^{\circ} \mathrm{a}^{\circ}$ ).

Cada floresta nacional deve dispor de um conselho consultivo presidido pelo órgão responsável pela administração da unidade constituído por representantes de órgãos públicos, de entidades da sociedade civil e, quando for o caso, das populações tradicionais residentes $\left(\S 5^{\circ}\right.$ do art. 17). 


\subsubsection{Reserva extrativista}

Área de domínio público utilizada por populações extrativistas tradicionais, cuja subsistência baseia-se no extrativismo e, complementarmente, na agricultura de subsistência e na criação de animais de pequeno porte, tendo por objetivos básicos proteger meios de vida e cultura dessas populações, assegurando o uso sustentável dos recursos naturais da unidade. A posse e o uso das áreas ocupadas por populações tradicionais serão regulados por contrato de concessão de uso. Essas populações ficam obrigadas a participar da preservação, recuperação, defesa e manutenção da unidade de conservação. A visitação publica é permitida, desde que de acordo com o plano de manejo (art. 18 e $\S \S 1^{\circ}$ e $3^{\circ}$ e art. 23 da Lei do SNUC).

A pesquisa cientifica é permitida e incentivada, sujeita a prévia autorização do órgão gerenciador da unidade ( $\S 4^{\circ}$ do art. 18).

Cada reserva extrativista será gerida por um conselho deliberativo presidido pelo órgão responsável por sua administração e constituído por representantes de órgãos públicos, de organizações da sociedade civil e das populações tradicionais residentes na área. Este mesmo conselho será responsável pela aprovação do plano de manejo da área ( $\S \S 2^{\circ}$ e $5^{\circ}$ do art. 18).

É proibida a exploração de recursos minerais e a caça amadorística ou profissional. A exploração de recursos madeireiros só será admitida em bases sustentáveis e em situações especiais e complementares às demais atividades desenvolvidas na unidade, de acordo com seu plano de manejo ( $\S 6^{\circ}$ do art. 18). 
4.1.2.5. Reserva de fauna

Área natural de posse e domínio públicos, com populações animais de espécies nativas, terrestres ou aquáticas, residentes ou migratórias, adequadas a estudos técnico-científicos sobre o manejo econômico de recursos faunísticos. Nela a visitação pública pode ser permitida, desde que compatível com o manejo da unidade, sendo ainda proibida a caça, seja amadorística ou profissional (art. 19 e $\S \S$ ).

\subsubsection{Reserva de desenvolvimento sustentável}

Área de domínio público que tem como objetivo básico preservar a natureza e, ao mesmo tempo, assegurar as condições e os meios necessários para a reprodução e a melhoria dos modos e da qualidade de vida exploração dos recursos naturais das populações tradicionais, bem como valorizar, conservar, aperfeiçoar o conhecimento e as técnicas de manejo do ambiente desenvolvidas por estas populações ( $\S \S 1^{\circ}$ e $2^{\circ}$ do art. 20 da Lei do SNUC).

A posse e o uso das áreas ocupadas pelas populações tradicionais são regulados de forma análoga à das reservas extrativistas. Também é gerida por um conselho deliberativo com as mesmas atribuições e composição daquele da reserva extrativista ( $\S \S 3^{\circ}$ e $4^{\circ}$ do art. 20$)$.

A visitação publica é permitida e incentivada, desde que compatível com o plano de manejo. É permitida e incentivada a pesquisa cientifica voltada à conservação da natureza, à melhor relação das populações residentes com seu meio e à educação ambiental (inc. I do $\S 5^{\circ}$ do art. 20). 
Admite-se a exploração de componentes dos ecossistemas naturais em regime de manejo sustentável e a substituição da cobertura vegetal por espécies cultiváveis, desde que de acordo com as limitações legais e do plano de manejo (inc. IV do $§ 5^{\circ}$ do art. 20).

\subsubsection{Reserva particular do patrimônio natural}

Trata-se de área privada, gravada com perpetuidade, com o objetivo de conservar a diversidade biológica. Nela somente é permitida a pesquisa cientifica e a visitação com objetivos turisticos, recreativos e educacionais (art. 21 e $\S \S$ ).

$\mathrm{Na}$ verdade esta categoria esta deslocada, já que nela somente se permitem atividades de uso indireto. Deveria a reserva particular do patrimônio natural situar-se entre aquelas classificadas como unidades dé proteção integral (RODRIGUES, 2005a, p.340).

Ocorre que a proposta original da Lei do SNUC previa a possibilidade de extração de recursos naturais, exceto madeira, desde que não colocasse em risco as espécies ou os ecossistemas que justificaram a criação da unidade. Esta disposição constava do inciso III do $\S 2^{\circ}$ do artigo 21 , que foi vetado pelo Presidente da República quando da promulgação da Lei 9985/2000. Daí resultou a incoerência mencionada (RODRIGUES, 2005a, p.340-341). 


\subsubsection{Reserva da biosfera}

Como categoria isolada da Lei do SNUC, não integrante de nenhum dos dois grupos, encontramos a reserva da biosfera. Trata-se de categoria internacional, reconhecida pelo programa inter-governamental "O Homem e a Biosfera - MAB", estabelecido pela Unesco, agência das Nações Unidas de que o Brasil é membro ( $\S 5^{\circ}$ do art. 41 da Lei do SNUC).

A reserva da biosfera é legalmente definida como modelo, adotado internacionalmente, de gestão integrada, participativa e sustentável dos recursos naturais, tendo como objetivos básicos de preservação a diversidade biológica, o desenvolvimento sustentável e a melhoria da qualidade de vida das populações (art. 41 , caput).

Pode esta categoria ser constituída por áreas de domínio público, inclusive por outras unidades de conservação já existentes. Deve possuir uma ou várias áreas-nicho e uma ou várias zonas de transição, sem limites rígidos, onde o processo de ocupação e o manejo dos recursos naturais devem ser planejados de modo participativo e em bases sustentáveis $\left(\S \S 1^{\circ}\right.$ a $3^{\circ}$ do art. 41$)$.

As reservas da biosfera devem ser geridas cada uma por um conselho deliberativo $\left(\S 4^{\circ}\right.$ do art. 41$)$. Seu gerenciamento é coordenado pela Comissão Brasileira para o Programa "O Homem e a Biosfera" (COBRAMAB), criada pelo Decreto Federal s/n ${ }^{\circ}$ de 21.09.1999. 
4.1.4. Criação e gestão das unidades de conservação

As unidades de conservação podem ser criadas por qualquer ato do poder público. Tal criação deve ser precedida de estudos técnicos e consulta pública que permita identificar a localização, dimensão e os limites mais adequados para a unidade. Nesse processo, o poder público deve fornecer informações adequadas e inteligíveis à população local e outros interessados. Apenas em caso de criação de estação ecológica e reserva biológica é que tal consulta pública não é obrigatória (art. 22 e $\S \S 2^{\circ}$ a $4^{\circ}$ da Lei do SNUC). O IBAMA vem adotando o entendimento de que a escolha da categoria da unidade de conservação a ser implantada não deve ser objeto de consulta, mas sim de deliberação técnica (RODRIGUES, 2005a, p.342).

O poder público ainda poderá decretar limitações administrativas provisórias ao exercício de atividades e empreendimentos, efetiva ou potencialmente causadores de degradação ambiental para a realização de estudos com vistas à criação de unidade de conservação quando, a critério do órgão ambiental competente, houver risco de dano grave aos recursos naturais ali existentes (art. 22-A, caput, da Lei do SNUC, inserido pela Lei 11.132 de 04/07/2005).

Tais limitações administrativas não devem impedir atividades agropecuárias e outras atividades econômicas em andamento, nem obras licenciadas na forma da lei. Mas nas áreas a elas sujeitas não serão permitidas atividades que importem em exploração a corte raso de floresta e demais formas de vegetação nativa (art. 22-A, caput e $\S 1^{\circ}$ ).

A destinação final das áreas submetidas a limitações administrativas deve ser definida no prazo improrrogável de sete meses, findo o qual estarão extintas as restrições ( $\left(2^{\circ}\right.$ do art. $\left.22-\mathrm{A}\right)$. Tal prazo, que não pode sequer ser prorrogado, parece muito limitado para a realização de estudos razoavelmente aprofundados, considerando as áreas comumente extensas necessárias à implantação de uma unidade de conservação, além do normalmente difícil acesso às mesmas. 
As unidades do grupo de uso sustentável podem ser transformadas total ou parcialmente em unidades do grupo de proteção integral, por instrumento normativo do mesmo nível do que criou a unidade original, desde que obedecido o procedimento de consulta. Igualmente quando se trata de ampliação dos limites de uma unidade de conservação. Já a desafetação ou redução de sues limites só pode ser feita por lei especifica ( $\$ \S 5^{\circ}$ a $7^{\circ}$ do art. 22$)$.

O subsolo e o espaço aéreo, sempre que influírem na estabilidade do ecossistema, devem integrar os limites das unidades de conservação (art. 24).

A Lei do SNUC permite que as unidades de conservação sejam geridas por organizações da sociedade civil de interesse público com objetivos afins aos da unidade, mediante instrumento a ser firmado com o órgão responsável por sua gestão (art. 30 da Lei do SNUC). Este instrumento é o chamado "termo de parceria" e esta entidade deve ser uma "Organização da Sociedade Civil de Interesse Público" (OSCIP), nos termos da Lei Federal 9.790, de 23/03/1999 (art. 21 do Dec. 4.340 de 22/08/2002).

A seleção da OSCIP para tornar-se gestora compartilhada deve ser precedida pela publicação de edital em jornal de grande circulação na região da unidade de conservação a ser gerida e no Diário Oficial, com no mínimo sessenta dias de antecedência, obedecida a Lei de Licitações e Contratos (Lei $\mathrm{n}^{\circ} 8.666$, de 21/06/1993) (art. 23 do Dec. 4.340/2002).

As populações tradicionais residentes em unidades de conservação nas quais sua permanência não seja permitida deverão ser indenizadas ou compensadas pélas benfeitorias existentes e devidamente reinstaladas pelo poder público em local e condições acordados pelas partes (art. 42 da Lei do SNUC). O grande problema é que nem a lei, nem seu regulamento conceituaram o que sejam "populações tradicionais", dando margem a possíveis manipulações. Por outro lado, as "populações tradicionais" beneficiadas são apenas aquelas preexistentes à criação das unidades, não admitindo a lei benefícios ou estímulos a invasores (RODRIGUES, 2005a, p.342-343). 
Todas as categorias de unidades de conservação, exceto área de proteção ambiental e reserva de proteção ao patrimônio natural, devem possuir uma zona de amortecimento e, quando conveniente, corredores ecológicos (art. 25, caput).

Zona de amortecimento é o entorno da unidade de conservação onde as atividades humanas estão sujeitas a normas e restrições específicas, com o propósito de minimizar os impactos negativos sobre a unidade (inc. XVIII do art. $2^{\circ}$ ).

Corredores ecológicos são porções de ecossistemas, ligando unidades de conservação, que possibilitam entre elas o fluxo genético e o movimento da biota, facilitando a dispersão de espécies e a recolonização de áreas degradadas, bem como a manutenção de populações que demandam para sua sobrevivência aéreas com extensão maior do que aquelas das unidades individuais (inc. XIX do art. $2^{\circ}$ ).

A Lei do SNUC denomina mosaico o conjunto de unidades de conservação de categorias diferentes ou não, próximas, justapostas ou sobrepostas a outras áreas protegidas. Nesse caso a sua gestão deve ser feita de forma integrada e participativa, considerando os seus distintos objetivos de conservação (art. 26 da Lei do SNUC). Assim, deve cada mosaico dispor de um conselho de mosaico com caráter consultivo e função de atuar como instância de gestão integrada das unidades que o compõem (art. $9^{\circ}$ do Dec. 4.340 de 22/08/2002).

Todas as unidades de conservação devem dispor de plano de manejo (art. 27, caput, da Lei do SNUC). Plano de manejo é um documento técnico mediante o qual, com fundamento nos objetivos gerais de uma unidade de conservação, é estabelecido o seu zoneamento e as normas que devem presidir o uso da área e o manejo dos recursos naturais, inclusive a implantação das estruturas físicas necessárias à gestão da unidade (inc. XVII do art. $2^{\circ}$ da mesma lei).

Por sua vez, zoneamento é a definição de setores ou zonas em uma unidade de conservação com objetivos de manejo e normas específicas, com o propósito de proporcionar os meios e as condições para que todos os objetivos da unidade possam ser alcançados de uma forma harmônica e eficaz (inc. XVI do art. $2^{\circ}$ da mesma lei). 
O plano de manejo deve abranger não apenas a área da unidade de conservação, mas também a sua zona de amortecimento e os corredores ecológicos, incluindo medidas com o fim de promover sua integração à vida econômica e social das comunidades vizinhas (art. 27 e $\S 1^{\circ}$ ).

São proibidas nas unidades de conservação, quaisquer alterações, atividades ou modalidades de utilização em desacordo com os objetivos, plano de manejo e seus regulamentos. Enquanto não tiver sido elaborado o plano de manejo, as atividades e obras desenvolvidas nas unidades devem limitar-se àquelas destinadas a garantir a integridade dos recursos que elas objetivam proteger. Devem também ficar assegurados os meios necessários à satisfação das necessidades materiais, sociais e culturais às populações tradicionais porventura residentes na área (art. 28).

Na elaboração, atualização e implementação do plano de manejo das reservas extrativistas, das reservas de desenvolvimento sustentável, das áreas de proteção ambiental e, quando for o caso, das florestas nacionais e das áreas de relevante interesse ecológico deve ser assegurada ampla participação da população residente $\left(\S 2^{\circ}\right.$ do art. 27$)$.

O plano de manejo de uma unidade de conservação deve ser elaborado no prazo de cinco anos a partir da data de criação ( $\left(3^{\circ}\right.$ do art. 27).

Nos casos de licenciamento ambiental de empreendimentos de significativo impacto ambiental, assim considerado pelo órgão ambiental competente, com fundamento em EIA/RIMA, o empreendedor fica obrigado a apoiar a implantação e manutenção de unidades de conservação do grupo de proteção integral. O montante de recursos não pode ser inferior a meio por cento dos custos totais previstos para a implantação do empreendimento, sendo o percentual fixado pelo órgão ambiental licenciador, de acordo com o grau de impacto ambiental do empreendimento (art. 36 e $\S 1^{\circ}$ ).

O órgão ou empresa, público ou privado, responsável pelo abastecimento de água, que faça uso de recursos hídricos, ou pela geração e distribuição de energia elétrica, beneficiário da proteção proporcionada por uma unidade de conservação, 
deve contribuir financeiramente para proteção e implementação da unidade, de acordo com regulamentação especifica, que lamentavelmente não foi efetuada até hoje (arts. 47 e 48 ).

A regulamentação da Lei do SNUC foi efetuada pelo Decreto Federal 4.340, de 22 de agosto de 2002. Este decreto buscou detalhar melhor os aspectos legais referentes à criação de unidades de conservação, subşolo e espaço aéreo, mosaico, plano de manejo composição dos conselhos, gestão compartilhada com OSCIP, exploração de bens de serviços, compensação por significativo impacto ambiental, reassentamento de populações tradicionais, reavaliação de categorias de unidades não previstas no sistema e gestão das reservas da biosfera.

\subsection{AUTONOMIA DAS UNIDADES FEDERADAS PARA CRIAÇÃO DE UNIDADES DE CONSERVAÇÃO INTEGRANTES DO SNUC}

A Lei $9.985 / 2000$ restringiu muito as autonomias estadual, municipal e distrital no que tange à criação de categorias de unidades de conservação integrantes do SNUC e que se coadunem com suas peculiaridades regionais e locais.

A lei praticamente impôs o modelo federal de unidades de conservação com todas as suas complexidades excessivas e defeitos de origem, os quais também não procurou solucionar. Inclusive, criou algumas categorias novas que, com todo respeito, não se justificam, seja do ponto de vista técnico ou político e excluiu outras importantes.

As unidades de conservação mais tradicionais como parques nacionais, reservas biológicas e florestas nacionais encontravam seu fundamento legal original 
no Código Florestal (art. $5^{\circ}$ da Lei 4.771 de 15/09/1965). Porém sua gestão coube por muito tempo ao IBDF (Instituto Brasileiro de Desenvolvimento Florestal), criado pelo Decreto-Lei 289/67. A cultura administrativa deste órgão estava mais voltada ao reflorestamento com espécies exóticas, que foi bastante estimulado pelo governo militar nas décadas de 1960/70 por meio de generosos incentivos fiscais.

Por sua.vez, para fazer frente às crescentes exigências internacionais de proteção ambiental decorrentes da Declaração de Estocolmo de 1972, o governo militar criou a Secretaria Especial de Meio Ambiente (SEMA), órgão integrante do então Ministério do Interior, por meio do Decreto 70.030 de 30/10/1973, com uma cultura mais moderna, voltada mais diretamente à questão ambiental, de cuja atuação, inclusive, resultou a elaboração da Lei de Política Nacional de Meio Ambiente (Lei 6.938 de 31/08/1981), até hoje um dos mais avançados e fundamentais diplomas legais vigentes sobre o tema no ordenamento jurídico brasileiro.

Como seria de se esperar, a mentalidade desenvolvimentista predominante no IBDF não tardaria a entrar em conflito com as idéias ambientalistas da SEMA. Como fruto deste conflito, a SEMA via-se impedida de atuar nas unidades de conservação existentes, sob administração do IBDF. Em razão disto, foram então criadas novas categorias de unidades de conservação, a estação ecológica e a área de proteção ambiental (Lei 6.902 de 27/04/1981), desta vez administradas pela SEMA.

Estes fatos explicam a acentuada semelhança entre o manejo da reserva biológica e o da estaçãao ecológica. A única diferença verdadeiramente relevante entre as duas categorias era a gestão por órgãos administrativos rivais, o IBDF e a SEMA.

Tempos depois, em razão de reforma administrativa que buscava unificar a questão ambiental num único órgão governamental, tanto o IBDF quanto a SEMA foram extintos (respectivamente pelas Leis 7.732 de 14/02/1989, e 7.735, de 22/02/1989), sendo substituídos em suas funções pelo Instituto Brasileiro do Meio Ambiente e dos Recursos Naturais Renováveis, o IBAMA (criado pelo art. $2^{\circ}$ da Lei 
7.735, de 22/02/1989). Hoje, a gestão das unidades de conservação cabe ao Instituto Chico Mendes de Conservação da Biodiversidade (criado pela Lei 11.516 de 28/08/2007).

Tendo em vista a unificação das ações ambientais à época pelo IBAMA, era de se esperar que as categorias reserva biológica e estação ecológica também se fundissem e uma delas fosse extinta. Não obstante isto não ocorreu, como também não ocorreria quando da promulgação da Lei do SNUC, o que poderia ter contribuído para a simplificação do sistema (RODRIGUES, 2005b, p.156).

Entre as áreas de proteção ambiental (APAs) e as áreas de relevante interesse ecológico (ARIEs) também encontramos uma crise de identidade. Ambas originalmente criadas em data anterior ao SNUC (respectivamente pelo art. $8^{\circ}$ da Lei 6.902, de 27/04/1981 e pelo art. $2^{\circ}$ do Decreto 89.336, de 31/01/1984) não apresentam entre si diferenças relevantes. E a Lei do SNUC, que bem poderia ter extinto uma das categorias, apenas repetiu o equívoco. Tanto que da leitura perfunctória dos arts. 15 e 16 da Lei do SNUC pode-se concluir que uma ARIE nada mais é do que uma APA pequena (RODRIGUES, 2005b, p.173).

Por sua vez, o conceito de reserva de desenvolvimento sustentável confunde-se em grande parte com o da reserva extrativista. Esta última categoria tem alcance mais restrito, já que a atividade a ser nela praticada deve ser primordialmente a extrativista, baseada na coleta e extração de modo sustentável de recursos naturais renováveis. Foi esta categoria originalmente criada pelo Decretó 98.897 de 30/01/1990, portanto anteriormente ao SNUC, com a finalidade específica de solucionar a questão da atividade seringueira na Amazônia. Já a reserva de desenvolvimento sustentável, criada pelo art. 20 da Lei do SNUC, é uma tentativa de ampliar o escopo da reserva extrativista para outras atividades sustentáveis (RODRIGUES, 2005b, p.182-183). Como expressa PÁDUA (2001, p.55), a diferença entre a reserva extrativista e a reserva de desenvolvimento sustentável é, na melhor das hipóteses, sutil e será nula na prática. 
O refúgio de vida silvestre, novidade introduzida pelo art. 13 da Lei do SNUC, tem como objetivo proteger ambientes naturais onde se assegurem condições para a existência ou reprodução de espécies ou comunidades de flora local e da fauna residente ou migratória. Pode ser constituído por áreas públicas e também particulares, desde que seja possível compatibilizar os objetivos da unidade com a utilização da terra e dos recursos naturais do local pelos proprietários.

Para o refúgio de vida silvestre, sob o ponto de vista de dominialidade, podemos conceber três hipóteses: (a) ele é formado apenas por áreas públicas; (b) apenas por áreas privadas e (c) simultaneamente por áreas públicas e privadas. $\mathrm{Na}$ primeira hipótese, mais provável, já que o tipo de manejo legalmente previsto praticamente inviabiliza a exploração econômica convencional, teremos uma categoria correspondente à estação ecológica (art. $9^{\circ}$ da lei do SNUC). Na segunda hipótese, onde o Estado precisa contar com a colaboração direta do proprietário particular, teremos uma categoria correspondente à reserva particular do patrimônio natural (art. 21 da mesma lei). Na terceira hipótese, haverá uma justaposição de unidades de conservação de categorias e regimes dominiais distintos, correspondente ao que o art. 26 da Lei do SNUC denomina de mosaico.

Sendo assim, com todo respeito àqueles que conceberam o refúgio de vida silvestre, temos aqui uma categoria de unidade de conservação, de recente criação, perfeitamente dispensável do ponto de vista técnico.

Já a reserva de fauna, outra novidade, criada pelo art. 19 da Léi do SNUC, é, segundo PÁDUA (2001, p.55), uma categoria incompreensível do ponto de vista técnico, eis que não há lógica em desapropriar áreas para fazer estudos técnicocientíficos sobre manejo da fauna se a caça nelas é proibida ( $\$ 3^{\circ}$ do referido art. 19$)$. Tais pesquisas, segundo a mesma autora, poderiam muito bem ser realizadas em estações ecológicas, parques nacionais, florestas nacionais, reservas extrativistas ou reservas de desenvolvimento sustentável.

Sabendo-se que o SNUC é um sistema jurídico e que como tal deve manter uma coerência lógica entre suas normas, é de se questionar o motivo pelo 
qual continuam a persistir em seu bojo várias categorias de unidades de conservação que não se distinguem claramente uma da outra, uma classificação desordenada resultante de erros passados. E o pior de tudo isso é que o legislador, além de perder uma preciosa oportunidade de corrigir tais erros, ainda criou outros na forma de novas categorias que não se justificam tecnicamente.

A resposta parece bastante simples. O SNUC, na verdade, não alterou em praticamente nada a situação preexistente das unidades de conservação que já estavam sob a tutela do IBAMA. O legislador assim agiu com a visível finalidade de evitar as despesas e os trabalhos que seriam necessários para se efetuar uma reclassificação tecnicamente consistente das unidades de conservação federais.

A Lei do SNUC, em seu art. 60, apenas extinguiu expressamente as categorias "parque de caça", "reserva ecológica" e "pouso de aves de arribação" das quais nunca foi criada uma unidade sequer. Pelo mesmo artigo deixou de considerar como unidades de conservação as áreas de preservação permanente, relacionadas no art. $2^{\circ}$ do Código Florestal, as quais de fato nunca foram tratadas como tal. Não acolheu como unidades de conservação as "áreas e locais de relevante interesse turístico" (disciplinados pela Lei 6.513 de 20.12.1977, regulamentada pelo Decreto 86.176 de 06.07.1981), as "reservas de regiões virgens" e as "reservas nacionais" (definidas pela Convenção para a Proteção da Flora, da Fauna e das Belezas Cênicas Naturais dos Países da América, promulgada no Brasil pelo Decreto 58.054 de 23/08/1966) cuja existência sempre foi letra morta (RODRIGUES, 1986, p.139-140). Revogou tacitamente a Resolução CONAMA n ${ }^{\circ} 11$ de 03/12/1987, em razão do que os jardins botânicos e jardins zoológicos deixaram de ser considerados formalmente como categorias de unidades de conservação (RODRIGUES, 2005b, p.37-38).

Para reclassificação, entre as unidades de conservação administradas pelo IBAMA, restaram apenas os "hortos florestais" e as "estações experimentais". Não incluídas no SNUC, tais categorias estão tendo suas denominações simplesmente substituídas por "florestas nacionais", o que de fato não acarreta maiores problemas (RODRIGUES, 2005b, p.37). 
O curioso é que a União, aparentemente tão interessada em evitar suas despesas, não teve a mesma preocupação com os erários das demais unidades federadas. A Lei 9.985/2000, em seu art. 55, determinou o prazo de dois anos após sua promulgação para reavaliar e definir a destinação das unidades de conservação e áreas protegidas criadas com base em legislações anteriores e que não pertençam às categorias nela previstas.

O SNUC é na verdade o sistema adotado pelas unidades de conservação federais, cujo escopo foi alargado para os demais entes federados. Portanto sobraria aos Estados, Municípios e Distrito Federal o ônus de se adaptarem, às suas custas, a um sistema, que com já dissemos, é bastante defeituoso e que na prática está sendo imposto por comodidade da União.

Nesse sentido, ANTUNES (2007, p.560) afirma que o SNUC é antes de tudo um Sistema Federal de Unidades de Conservação do que um Sistema Nacional.

Daí a Lei 9.985/2000 abrir pouquíssimo espaço para a criação de categorias estaduais, municipais e distritais de unidades de conservação que possam integrar o SNUC. Basta observar que a lista de categorias de unidades de conservação que nela encontramos é taxativa. Segundo o $\S$ único do seu art. $6^{\circ}$, apenas excepcionalmente e com autorização do Conselho Nacional do Meio Ambiente (CONAMA), outras unidades de conservação estaduais e municipais poderão vir a integrar o SNUC, desde que preenchidas três condições: (a) tenham sido concebidas para atender a peculiaridades regionais; (b) possuam objetivos de manejo que não possam ser satisfatoriamente atendidos por nenhuma categoria prevista na Lei do SNUC; (c) tenham características que permitam uma clara distinção daquelas categorias integrantes do SNUC (RODRIGUES, 2005b, p.87). 


\subsection{AUTONOMIA DAS UNIDADES FEDERADAS PARA CRIAR UNIDADES DE CONSERVAÇÃO FORA DO SNUC}

Em princípio é preciso analisar-se a possibilidade de existência de unidades de conservação no ordenamento jurídico brasileiro que não estejam elencadas no SNUC. Isto é, se a lista do SNUC não é taxativa a ponto de ter eliminado do mundo jurídico todas as demais unidades de conservação possiveis, sejam as pré-existentes ou ainda outras categorias que poderiam vir a ser criadas pelos Estados, Municípios e Distrito Federal.

Como já foi dito, o SNUC é bastante centralizador em termos legais, a ponto de restringir severamente a criação de unidades de conservação de características especificamente regionais e locais, só as admitindo excepcionalmente, mediante autorização do CONAMA.

Unidade de conservação, segundo a Lei do SNUC, é todo aquele espaço territorial e seus recursos ambientais, incluindo as águas jurisdicionais, com características naturais relevantes, legalmente instituído pelo Poder Público, com objetivos de conservação e limites definidos, sob regime especial de administração, ao qual se aplicam garantias adequadas de proteção (inc. I do art. $2^{\circ}$ ).

Tendo em conta este conceito legal, é possivel defender a legalidade da existência de unidades de conservação não integrantes do SNUC. E ainda, do ponto de vista doutrinário, pode-se esboçar uma classificação das unidades de conservação em duas espécies: unidades de conservação em sentido estrito e unidades de conservação em sentido amplo.

Unidade de conservação em sentido estrito é aquele espaço territorial integrante das categorias expressamente previstas na Lei do SNUC (arts. $8^{\circ}$, incs. I a V e 14 , incs. I a VII). 
Unidade de conservação em sentido amplo é aquele espaço territorial previsto no ordenamento jurídico brasileiro, que embora não integre nenhuma das categorias expressamente previstas na Lei do SNUC, pode ser enquadrado no conceito de unidade de conservação contido no seu art. $2^{\mathbf{0}}$, inc. $\mathrm{I}^{{ }^{1}}$.

4.3.1. Unidades de conservação federais em sentido amplo

O mais claro exemplo de unidade de conservação em sentido amplo é a reserva da biosfera. Embora prevista na Lei do SNUC (art. 41), como modelo internacional de gestão integrada, participativa e sustentável dos recursos naturais, tendo como objetivos básicos a preservação da diversidade biológica, o desenvolvimento de atividades de pesquisa, o monitoramento ambiental, a educação ambiental, o desenvolvimento sustentável e a melhoria da qualidade de vida das populações, a reserva da biosfera constitui-se em categoria que não pertence ao grupo de unidades de proteção integral, nem ao de unidades de uso sustentável (arts. $8^{\circ}$ e 14 da Lei do SNUC).

Pode-se incluir nesse mesmo rol a reserva de regiões virgens definidas no art. $1^{\circ}$ da Convenção para a Proteção da Flora, da Fauna e das Belezas Cênicas Naturais, adotada em Washington em 1940, somente promulgada no Brasil pelo Dec. 58.054 , de 23/08/1966, como região administrada pelo poder público, onde existem condições primitivas naturais de flora, fauna, habitação e transporte, com ausência de caminhos para o tráfego de veículos e onde é proibida toda a exploração comercial. Igualmente, a denominada reserva nacional, que a sobredita convenção define como

\footnotetext{
' Nesse mesmo diapasão BENJAMIN (2001) menciona dois tipos de unidades de conservação: as típicas, que são as acolhidas pela Lei do SNUC e as atipicas, como aquelas previstas em outros dispositivos do ordenamento jurídico brasileiro, ou mesmo sem expressa previsão legal, desde que suas características correspondam ao conceito de unidade de conservação expresso no art. $2^{\circ}$, inc. I, da Lei 9.985 , de 18/07/2000 (p.44-45). Este conceito difere do nosso apenas pelo fato de entender como existentes unidades de conservação sem previsão legal.
} 
região estabelecida para a conservação e utilização, sob a vigilância oficial, das riquezas naturais, nas quais se protegerá a flora e a fauna tanto quanto compatível com os fins para os quais estas reservas forem criadas (RODRIGUES, 1996, p.140).

Embora estas categorias nunca tenham sido implantadas em território nacional, sendo inclusive totalmente ignoradas pela Lei do SNUC, sua existência no mundo jurídico resultou de promulgação de Tratado Internacional. Ora, sua revogação exigiria denúncia, pela qual o Estado Brasileiro manifestaria sua vontade de deixar de ser parte do acordo internacional, por meio de mensagem a ser remetida ao depositário do tratado, que deverá divulgá-la às demais partes (REZEK, 1991, p.111-112). Até que se efetive tal denúncia, as reservas de regiões virgens e as reservas nacionais continuam como categorias de unidades de conservação integrantes do ordenamento juridico brasileiro.

Entre as categorias de unidades de conservação em sentido amplo internacionais encontramos também a zona úmida de interesse internacional, o sítio do patrimônio mundial natural e o geoparque nacional.

As zonas úmidas de interesse internacional são conceituadas como "áreas de pântano, charco, turfa ou água, natural ou artificial, permanente ou temporária, com água estagnada ou corrente, doce, salobra ou salgada, incluindo áreas de água marítima com menos de sete metros de profundidade na maré baixa", consideradas de "importância internacional em termos ecológicos, botânicos, zoológicos, limnológicos ou hidrológicos", em especial "para as aves aquáticas em qualquer estação do ano", podendo "incorporar áreas ribeirinhas e litorais adjacentes e ilhas ou porções de água marítima com mais de seis metros de profundidade na maré baixa, situadas dentro da área úmida, principalmente onde estas tiverem importância como hábitat de aves marinhas". Foram criadas pela Convenção relativa a Zonas Úmidas de Importância Internacional, Particularmente como Habitat das Aves Aquáticas, adotada na cidade de Ramsar no Irã em 1971. No Brasil a autorização para adesão à Convenção de Ramsar foi dada pelo Dec. Leg. 33, de 17/06/1992 (SOARES, 2001, p.343-345). 
Esta categoria de unidade de conservação está em plena vigênçia no Brasil. Atualmente (fevereiro de 2008) existem sete zonas úmidas de importância internacional em território brasileiro, a saber: Parque Nacional da Lagoa do Peixe (RS), com 34.400 hectares e Parque Nacional do Pantanal Mato-grossense (MT), com 135.000 hectares, designados em 24/05/1993; Parque Nacional do Araguaia (TO), com 562.312 hectares e Reserva de Desenvolvimento Sustentável de Mamirauá (AM), com 1.124.000 hectares, designados em 04/10/1993; Área de Proteção Ambiental das Reentrâncias Maranhenses (MA) com 2.680.911 hectares, designada em 30/11/1993; Área de Proteção Ambiental da Baixada Maranhense (MA), com 1.775.036 hectares e Parque Estadual do Parcel Manuel Luiz, incluindo os baixios do Mestre Álvaro e do Tarol (MA), com 45.237 hectares, designados em 29/02/2000 (RAMSAR).

Os sítios do patrimônio mundial natural surgem com a Convenção relativa à Proteção do Patrimônio Mundial Natural e Cultural de 1972, adotada em Paris pela Unesco em 23/11/1972. Esta convenção define como "patrimônio natural" em seu art. $2^{\circ}$ :

a) os monumentos naturais constituídos por formações físicas e biológicas ou por grupos de tais formações, que tenham um valor excepcional do ponto de vista estético ou científico;

b) as formações geológicas e fisiográficas e áreas nitidamente delimitadas, que constituam o habitat de animais e vegetais ameaçados e que tenham valor universal excepcional, do ponto de vista da ciência ou da conservação;

c) os lugares notáveis naturais ou zonas nitidamente delimitadas, que tenham valor universal excepcional do ponto de vista da ciência, da conservação ou da beleza natural (SOARES 2001, p.453-455).

No Brasil existem atualmente (fevereiro de 2008) sete sítios do patrimônio mundial natural: Parque Nacional do Iguaçu (reconhecido em 1986); Mata Atlântica: Reservas do Sudeste (em 1999); Costa do Descobrimento: Reservas 
de Mata Atlântica (em 1999); Complexo de Conservação da Amazônia Central (em 2000 e 2003); Área de Conservação do Pantanal (em 2000); Ilhas Atlânticas Brasileiras: Fernando de Noronha e Atol das Rocas (em 2001); Áreas de Proteção do Cerrado: Parques Nacionais da Chapada dos Veadeiros e das Emas (em 2001) (WORLD WILDLIFE FUND).

Os geoparques nacionais são áreas com patrimônio geológico significativo, com estrutura de gerenciamentó bem organizada e estratégia implantada de desenvolvimento econômico sustentável. A criação de um geoparque deve intensificar as oportunidades de emprego para as pessoas que nele habitam, trazendo benefícios econômicos efetivos, especialmente através do turismo sustentável. O geoparque pretende partilhar o patrimônio geológico e seu conhecimento entre as geociências e um amplo público visitante, além de buscar preservar os vários aspectos da natureza e do ambiente cultural local, freqüentemente relacionados ou determinados pela geologia e pela paisagem, para as presentes e futuras gerações. Sob a tutela da Unesco e através do intercâmbio entre os integrantes da Rede Mundial de Geoparques, importantes sítios geológicos nacionais têm a oportunidade de obter reconhecimento global, além de serem beneficiados pela troca de conhecimento, experiências e assistência especializada com outros geoparques (UNESCO).

Com uma área de 10 mil quilômetros quadrados, um terço de todas as espécies de pterossauros (répteis alados) descritas no planeta e mais de vinte ordens de insetos, com idade estimada entre 70 e 120 milhões de anos, a Chapada do Araripe, no Ceará, foi incluída na Rede Mundial de Geoparques da Unesco em setembro de 2006. Trata-se do primeiro geoparque do hemisfério sul (UNESCO BRASIL).

As áreas de proteção especial estão previstas no art. 13, inc. I e 14 da Lei 6.766, de 19/12/1979, que dispõe sobre o parcelamento do solo urbano. Com fundamento em tais dispositivos, elas podem ser criadas por decreto estadual com a finalidade de proteger em áreas sujeitas a parcelamento do solo, isto é, urbanas, de 
expansão urbana ou de urbanização específica (art. $3^{\circ}$ do mesmo diploma legal), os mananciais ou o patrimônio cultural, histórico, paisagístico e arqueológico.

Em Minas Gerais existem cerca de vinte e cinco áreas de proteção especial (MIRANDA). O Superior Tribunal de Justiça reconheceu recentemente a sua validade:

" $\mathrm{Da}$ interpretação sistemática dos arts. 13 da Lei 6.766/79 e 225 da CF, extrai-se a necessidade de o Estado interferir, repressiva ou preventivamente, quando o loteamento for edificado em áreas tidas como de interesse especial, tais como as de proteção aos mananciais" (STJ - REsp 333.056SP - Rel. Min. Castro Meira. J. 13.12.2005) (apud MIRANDA).

A importância desta categoria, especificamente voltada para o meio urbano, está primordialmente em servir como instrumento jurídico hábil nas mãos do Estado para impedir que os municípios em sua atividade de urbanização cometam excessos, a ponto de danificar os mananciais, essenciais ao fornecimento de água para a população, ou o patrimônio cultural.

As áreas especiais e locais de interesse turístico, por sua vez, foram estabelecidas pela Lei 6.513 , de 20/12/1977. As áreas especiais de interesse turístico são trechos contínuos do território nacional, inclusive suas ágụas territoriais, a serem preservados e valorizados no sentido cultural e natural e destinados à realização de planos e projetos de desenvolvimento turístico (art. $3^{\circ}$ do referido diploma legal. Elas devem ser instituídas por decreto do Poder Executivo mediante proposta do Conselho Nacional de Turismo (art.11). Locais de interesse turístico são trechos do território nacional, compreendidos ou não em áreas especiais, destinados por sua adequação ao desenvolvimento de atividades turísticas 'e à realização de projetos específicos e que compreendam bens não sujeitos a regime específico de proteção e os respectivos entornos de proteção e ambientação (art. $4^{\circ}$, incs. I e II). Sua instituição deve ser feita por resolução do Conselho Nacional de Turismo, mediante proposta da autarquia EMBRATUR para fins de disciplina de seu uso e ocupação, preservação, proteção e ambientação (art. $18^{\circ}$ do mesmo diploma legal). 
Segundo SANTOS $(1999$, p.90) as áreas especiais de interesse turístico têm sido utilizadas pelo Estado do Paraná para garantir a proteção dada as suas áreas litorâneas.

É de se crer que as áreas especiais e locais de interesse turístico não foram acolhidas entre as unidades de conservação do SNUC, tendo em vista o fato de que a sua administração sempre coube aos órgãos turísticos governamentais e nunca ao IBAMA.

O SNUC excluiu estranhamente todas as categorias de unidades de conservação ex situ, isto é, que preservam seres vivos fora de seu ecossistema natural. Este é o caso de duas das mais tradicionais categorias de unidades de conservação existentes no Brasil: o jardim zoológico e o jardim botânico.

O jardim zoológico é regulado pela Lei 7.173, de 14/12/1983. Considerase jardim zoológico qualquer coleção de animais silvestres mantidos vivos em cativeiro ou semiliberdade e expostos à visitação pública. Podem ser de domínio público ou privado necessitando em ambos os casos de reconhecimento oficial.

O jardim botânico foi definido como área protegida constituída, no seu todo ou em parte, por coleções de plantas vivas cientificamente reconhecidas, organizadas, documentadas e identificadas, com a finalidade de estudo, pesquisa e documentação do patrimônio florístico do país, acessível ao público, no todo ou em parte, servindo à educação, à cultura, ao lazer e à conservação do meio ambiente, conforme o art. $1^{\circ}$ da Resolução CONAMA 266, de 03/08/2000. No entanto, esta resolução foi revogada ${ }^{2}$. Assim sendo, apesar do primeiro jardim botânico, o do Rio de Janeiro, ter sido criado pelo Decreto de 11/10/1808, sendo, portanto, a mais antiga unidade de conservação do Brasil, paradoxalmente não existe regulamentação legal que sistematize a criação e requisitos mínimos para o funcionamento de tão tradicional instituição (RODRIGUES, 1996, p.139).

\footnotetext{
${ }^{2}$ Paulo Afonso Leme Machado já considerava esta resolução ilegal, ao entender que a Lei $6.938 / 1981$ não concede ao CONAMA poder para criar unidades de conservação, nem estabelecer regras para seu funcionamento ( MACHADO, 2005, p.810)
} 
Destarte, cada jardim botânico apresenta um regime juridico próprio. Por exemplo, o Jardim Botânico do Rio de Janeiro constitui-se numa autarquia federal vinculada ao Ministério do Meio Ambiente, denominada "Instituto de Pesquisas Jardim Botânico do Rio de Janeiro", conforme a Lei 10.316, de 06/12/2001. Já o Jardim Botânico do Estado de São Paulo é uma Divisão do Instituto de Botânica do Estado de São Paulo, criado pelo Decreto Estadual 12.499, de 07/01/1942, este instituto por sua vez subordinado à Secretaria de Estado do Meio Ambiente pelo Decreto Estadual 26.942, de 01/04/1987.

Temos ainda entre as unidades de conservação em sentido amplo os bens naturais tombados (RODRIGUES 1996, p.134-135). Para muitos pode parecer estranho tratar-se de áreas e bens protegidos pelo tombamento como unidades de conservação. Ora, pode-se definir o tombamento como sendo um ato administrativo pelo qual o poder público declara o valor cultural de coisas móveis ou imóveis, inscrevendo-as no respectivo livro de tombo, sujeitando-as a um regime especial que impõe limitações ao exercício de proprièdade, com a finalidade de preservá-los.

Pois bem, o tombamento é um instrumento constitucional adequado à proteção do patrimônio cultural brasileiro (art. $216, \S 6^{\circ}$ da Constituição Federal). Pela definição de patrimônio cultural brasileiro, contida no art. 216 caput e incs., concluímos que este é formado de bens intangíveis (sem existência concreta), mencionadas nos incs. I a III e de bens tangíveis (de existência concreta), referidos nos incs. IV e V.

O tombamento, por sua própria natureza jurídica, é adequado apenas à proteção dos bens tangíveis, Estes, por sua vez, dividem-se em móveis e imóveis. Para os fins deste trabalho vamos ater-nos aos bens imóveis que se constituem obviamente em espaços territoriais de dimensões distintas, maiores ou menores, conforme seu porte fisico, mas sempre espaços territoriais.

Assim, não resta dúvida de que o tombamento atinge espaços (bens imóveis) de valor cultural, entre os quais estão sítios de valor paisagístico, ecológico 
e cientifico (inc. $\mathrm{V}$ do supracitado art. 216). Ao atingir tais espaços territoriais, o tombamento torna-os especialmente protegidos em função de valores ambientais.

Concluindo, os bens naturais tombados pelo seu valor ecológico, paisagístico ou científico, de forma individual ou em conjunto, ocupando espaços territoriais como uma Serra do Mar, um parque como o Ibirapuera, uma praça ou de tamanho a abrigar uma única árvore, já que a Carta Magna não distinguindo dimensões não autoriza o intérprete da lei a fazê-lo, podem ser compreendidos como unidades de conservação em sentido amplo e, como tal, espaços territoriais especialmente protegidos, sendo a alteração e a supressão permitidas somente através de lei, vedada qualquer utilização que comprometa a integridade dos atributos que justifiquem sua proteção, conforme o art. $225, \S 1^{\circ}$, inc.III.

Este entendimento tem importantes conseqüências jurídicas em se tratando de cancelamento do tombamento pelo poder público de bens imóveis que se encontram assim protegidos. Pois apenas a lei, norma geral e abstrata, emanada do poder legislativo, tem o condão de cancelar ou reduzir as limitações determinadas por um ato de tombamento, em cada caso concreto. E mais, tal cancelamento só é possível se inexistir o valor ambiental que justificou o tombamento.

Como se pode ver, a relação das categorias de unidades de conservação prevista no SNUC não é taxativa. Tanto que na própria esfera federal encontramos um bom número de categorias de unidades de conservação que não se encontram elencadas no SNUC, isto é, em sentido amplo.

Porém nenhuma delas é especificamente voltada à proteção do verde urbano. Apenas as áreas de proteção especial, os bens naturais tombados e os jardins botânicos podem exercer também essa função. 
4.3.2. Unidades de conservação estaduais e distritais em sentido amplo: sistemas estaduais de unidades de conservação

É inquestionável a competência dos Estados e do Distrito Federal para criar categorias de unidades de conservação próprias em sentido amplo, isto é, fora do rol daquelas integrantes do SNUC. Pelo inc. VI do art. 24 da Constituição Federal temos a competência concorrente da União, dos Estados e do Distrito Federal para legislar sobre florestas, fauna, conservação da natureza, defesa dos recursos naturais e proteção do meio ambiente. À União cabe estabelecer normas gerais e aos Estados e Distrito Federal a competência de estabelecer normas suplementares $\left(\S \S 1^{\circ}\right.$ e $2^{\circ}$ do mesmo artigo).

De acordo com CUSTÓDIO (2005, p.339), no âmbito da competência suplementar, devem prevalecer sempre as disposições de natureza mais restritiva ajustáveis às respectivas peculiaridades territoriais, compatíveis com os objetivos das normas gerais de proteção ambiental. Por sua vez, YOSHIDA (2008, p.37) explica que os precedentes jurisprudenciais em face da Constituição Federal orientam-se nesse sentido (ADIN n ${ }^{\circ}$ 384-4/PR e RE 286789/RS). Convém observar que existe acórdão que admite maiores restrições pela legislação suplementar estadual e municipal, não, contudo, a vedação da atividade (REsp n $29.299-6 / R S$ ).

Como confirma FIGUEIREDO (2008a, p.186), por tratar-se de norma geral, a Lei 9.985/00 não exclui a competência suplementar dos Estados membros da República Federativa do Brasil. Estes poderão, eventualmente, manter ou criar diferentes modalidades de unidades de conservação. As unidades de conservação não integradas ao sistema nacional de unidades de conservação podem ser regulamentadas por legislação estadual em tudo o que não contrarie as normas gerais presentes na Lei do SNUC.

Segundo AGUIAR (2002, p.197), o Supremo Tribunal Federal deixou consignado expressamente no Ag 156.115, rel. Min. Marco Aurélio, $2^{\mathrm{a}} \mathrm{T}$., que “À 
União cabe baixar as normas gerais sobre a defesa e a proteção da saúde, a abranger as relativas ao meio ambiente. A atuação dos Estados mostra-se válida no que não as contrariem".

ANTUNES (2007, p.560-561) trata esta questão sob o ângulo da autoorganização dos Estados. Assim, segundo este autor é de se observar o art. 25 da Constituição Federal, que reconhece a capacidade de auto-organização dos Estados, observados os princípios estabelecidos pela Carta Maior. E entre os princípios constitucionais, que se entendem obrigatórios aos Estados, não há um sequer relacionado à forma pela qual eles devam exercer a gestão de seus bens imóveis, sejam eles unidades de conservação ou não. Complementa o mesmo doutrinador que a limitação à auto-organização não deve ser interpretada de forma extensiva, sob pena de atentar contra o próprio modelo federal.

Tendo em vista que a Constituição Federal, em seu art.18, assegura a autonomia dos entes políticos federativos, União, Estados, Distrito Federal e Municípios, nos termos da mesma, MACHADO (2005, p.808-809) afirma que não se pode obrigar os Estados e Municípios a integrarem o SNUC. As normas da Lei 9.985/2000 aplicam-se à União, aos Estados, ao Distrito Federal e aos Municípios, na medida em que eles criarem e mantiverem unidades que se ajustem aos dispositivos dessa lei. Seria, contudo, uma clara desobediência ao princípio constitucional da supremacia da norma geral federal, em matéria de meio ambiente (art. 24 da Constituição Federal), se alguns desses entes políticos utilizassem dos nomes das unidades de conservação constantes da Lei 9.985 e dessem para essas unidades outro regime jurídico.

Respeitando as normas gerais da Lei do SNUC, especialmente os conceitos referidos no art. $2^{\circ}$, como o de "unidade de conservação" mencionado no inc. I e os objetivos e diretrizes arrolados, respectivamente, nos arts. $4^{\circ}$ e $5^{\circ}$, não se vislumbra nenhum óbice legal a que os Estados e o Distrito Federal criem categorias próprias de unidades de conservação, não arroladas no SNUC, ou seja, unidades de conservação em sentido amplo. Obviamente, tais unidades devem ter denominação distinta daquelas integradas ao SNUC. 
Quanto ao reconhecimento pelo CONAMA dessas categorias de unidades de conservação como integrantes do SNUC, de que trata o art. $6^{\circ}$, § único da Lei do SNUC, pode este vir a ocorrer, ou não, dependendo da conveniência e oportunidade da correspondente administração pública estadual ou distrital. $O$ fato de uma categoria de unidade de conservação estadual ou distrital não ser reconhecịda como integrante do SNUC não tem maiores implicações jurídicas: Desse tipo de categoria dir-se-á apenas que não pertence ao SNUC, mas nunca que é iléegal ou inconstitucional.

Aliás, os Estados e Distrito Federal podem criar sistemas próprios de unidades de conservação, afeitos a suas peculiaridades regionais, onde seriam incluídas as respectivas categorias de unidades de conservação em sentido amplo. Teríamos então "sistemas estaduais de unidades de conservação" e "sistema distrital de unidades de conservação", além do "sistema nacional de unidades de conservação".

Nada há de extraordinário nisso, caso mencionemos os Estados Unidos onde, segundo LANGLEY (2001, p.134-154), existem seis sistemas federais de unidades de conservação, administrados por quatro agências distintas, que convivem com outros cinqüenta sistemas estaduais.

Destarte, estão a seguir relacionados todos os Estados e Distrito Federal, sob o ponto de vista de possuírem, ou não, categorias de unidades de conservação em sentido amplo próprias, não integrantes do SNUC e de manterem, ou não, sistemas estaduais de unidades de conservação:

(1) Estados que não possuem categorias próprias de unidades de conservação independentes do SNUC (unidades de conservação em sentido amplo):

Espirito Santo, Mato Grosso do Sul, Pará, Paraíba, Paraná, Pernambuco, Rio de Janeiro e Roraima. 
(2) Estados que possuem categorias próprias de unidades de conservação independentes do SNUC (unidades de conservação em sentido amplo):

Alagoas, Ceará, Piauí, São Paulo e Distrito Federal.

(3) Estados que possuem sistema estadual de unidades de conservação:

Acre, Amapá, Amazonas, Bahia, Goiás, Maranhão, Mato Grosso, Minas Gerais, Rio Grande do Norte, Rio Grande do Sul, Rondônia, Santa Catarina, Sergipe e Tocantins.

4.3.2.1. Categorias de unidades de conservação independentes do SNUC por Estado

Alagoas: pelo Decreto Estadual 35.732, de 01/04/1993, foi criada uma reserva de preservação ecológica em cem hectares da fazenda denominada "Frios", própria do Estado de Alagoas, porém não se definem sequer as limitações por ela sofridas (ALAGOAS, 1993). Pelo Decreto Estadual 32.510, de 06/07/1987, foi criado um cinturão verde de proteção ambiental na Restinga do Pontal da Barra, cedido em permissão de uso à Salgema Indústrias Químicas Ltda., destinado a isolar as unidades industriais dessa empresa das residências existentes no local (ALAGOAS, 1987). Parece trata-se de uma espécie de área de preservação ambiental, em cujo perímetro não se permite a edificação de unidades habitacionais, nem de equipamentos de lazer.

Ceará: existem três categorias próprias utilizadas de forma pontual: parque ecológico do Rio Socó, corredor ecológico do Rio Pacoti e parque botânico do Ceará em Caucaia. No entanto, tais categorias estão em revisão para adequação à Lei do SNUC, inclusive com proposta de transformação do parque ecológico em parque estadual (CEARÁ). 
Piauí: este Estado tem duas categorias próprias: o parque zoobotânico, tratado como unidade de conservação de proteção integral e o parque ecológico, compreendido como unidade de uso sustentável (COMPANHIA DE DESENVOLVIMENTO DOS VALES DO SÃO FRANCISCO E DO PARNAÍBA). Existe o Parque Zoobotânico de Teresina com 150 hectares, administrado pela Secretaria Estadual do Meio Ambiente e Recursos Hídricos. Tem por objetivos a preservação da mata nativa local e a utilização de parte da área como jardim zoológico. Seu plano diretor está em elaboração (PIAUÍ). Existe também o Parque Ecológico da Cachoeira do Urubu no município de Esperantina, cujo objetivo básico é a preservação da referida cachoeira, além de servir de área de lazer (REVISTA CALOR).

São Paulo: Aqui encontramos algumas categorias de unidades de conservação em sentido amplo isoladas. São os parques ecológicos e as reservas estaduais.

Parques ecológićos são unidades de múltiplos aspectos, que explicitam na sua estrutura e dinâmica os diversos conceitos relacionados tanto à conservação quanto à recuperação ambiental (SÃO PAULO, 2001, p.16).

Devem ser de fácil acesso à população e possuir área maior do que cinqüenta hectares para que possam reunir diversos elementos importantes, como mata com espécies nativas, arboreto, viveiro, trilhas educativas, lagos, possibilitando a sensibilização da comunidade, difusão de informações e capacitação técnica (SÃO PAULO, 2001, p.16).

Além desses aspectos, trata-se de uma unidade com destaque para o paisagismo, geralmente próxima à área urbana. Portanto atua também como centro cultural e de lazer voltado, de preferência, ao reforço da identidade homem-natureza (SÃO PAULO, 2001, p.16).

Já a reserva estadual é uma categoria de manejo transitório, cujos recursos naturais devem ser conhecidos e preservados para uso futuro, quando serão reclassificados os objetivos para determinação de seu manejo permanente (SÃO PAULO, 2001, p.18). 
Distrito Federal: Nele existem as áreas de proteção de mananciais, que são definidas no $\S 2^{\circ}$ do art. $1^{\circ}$ do Dec. 18.585 , de 09/09/1997, que regulamenta o art. 30 da Lei Complementar 17, de 28/01/1997, que trata das áreas de proteção ambiental criadas pelo plano diretor de ordenamento territorial do Distrito Federal. São elas áreas destinadas à conservação, recuperação e manejo das bacias hidrográficas a montante dos pontos de captação de água para abastecimento público administrados pela Companhia de Águas e Saneamento Ambiental do Distrito Federal (CAESB), sem prejuízo das atividades e ações inerentes à competência de captar e distribuir água à população (CAESB).

São objetivos das áreas de proteção de mananciais: garantir a qualidade e disponibilidade dos recursos hídricos, tendo em vista o abastecimento público; promover o disciplinamento das atividades de uso e ocupação do solo no seu interior, visando a manutenção da qualidade e quantidade de água captada; assegurar a manutenção dos ecossistemas e a recuperação das áreas degradadas dentro dos polígonos de contribuições das captações (art. $2^{\circ}$ do Dec. 18.585) (CAESB).

Nas áreas de proteção de mananciais é: proibido o parcelamento do solo urbano e rural, à exceção dos parcelamentos regulares já existentes ou com projetos registrados em cartório nas bacias de captação discriminadas no bojo do decreto; restrita a atividade agropecuária aos locais atualmente utilizados para'este fim, devendo ser implantadas técnicas de controle ambiental e uso adequado do solo; assegurada a existência dos maciços florestais, estabelecendo-se um manejo que permita a transformação dos homogêneos em heterogêneos; proibido o lançamento direto e indireto de efluentes; vedada a instalação de indústrias poluentes; vedada a exploração de minerais; disciplinado o uso de áreas subterrâneas; exigido o licenciamento ambiental sem prejuízo de outras licenças cabíveis, de toda e qualquer atividade potencialmente poluidora causadora de erosão ou outras formas de degradação ambiental (art. $3^{\circ}$ do Decreto 18.585) (CAESB).

A gestão, manutenção e fiscalização das áreas de proteção de mananciais competem à CAESB (art. $4^{\circ}$ do Decreto 18.585). A participação popular na gestão concretiza-se por meio de representantes nos comitês de bacias hidrográficas, 
correspondentes às áreas de proteção de mananciais, os quais são instrumentos de gestão (art. $7^{\circ}$ do mesmo decreto) (CAESB).

Outra categoria de unidade de conservação específica distrital é a do parque ecológico e de usos múltiplos, cujos objetivos são o proteção de atributos naturais localizados em áreas urbanas ou vizinhas a elas, predominantemente cobertas com vegetação nativa ou exótica, com finalidades educacionais, recreativas e científicas. Sua criação é regida pela Lei Complementar 265, de 14/12/1999. A administração de cada parque, geralmente estabelecida pelo ato de criação, pode ficar a cargo da respectiva administração regional ou da COMPARQUES (Secretaria de Parques e Unidades de Conservação) (SEBRAE).

Com se vê, as categorias unidades de conservação em sentido amplo, criadas pelos Estados de forma isolada, são anteriores ao SNUC, geralmente de definição imprecisa e implantação precária. Tanto que tendem a ser redenominadas, nos termos da Lei do SNUC. As exceções ficam para a área de proteção de mananciais (Distrito Federal), reserva estadual (São Paulo), parque zoobotânico (Piauí) e parques ecológicos (Piauí, São Paulo e Distrito Federal).

As áreas de proteção de mananciais distritais são bastante semelhantes às áreas de proteção especial, categoria federal comentada acima; porém sua disciplina jurídica é mais bem elaborada: O Dec. 18.585 deixa bem claro os objetivos da categoria, as suas restrições e forma de gestão, com espaços abertos para a participação popular.

As reservas estaduais paulistas, como unidades de conservação de manejo provisório, preenchem importante lacuna do SNUC. Através dessa categoria é possivel, em situação de urgência, a preservação de áreas sobre as quais ainda não existam estudos suficientes para designar seu manejo definitivo.

O jardim zoobotânico piauiense, misto de jardim botânico e jardim zoológico, embora existente apenas em Teresina, é bastante importante, na medida em que supre a ausência no SNUC de categorias de preservação ex situ. 
Para os objetivos de nosso trabalho, a categoria mais importante aqui mencionada é a do parque ecológico. Segundo os conceitos adotados no Distrito Federal e no Estado de São Paulo, os mais elaborados, o parque ecológico é uma unidade de conservação urbana, que contém vegetação nativa ou exótica, com destaque para o paisagismo e finalidades educacionais, recreativas e científicas. Ficam bem nítidas as suas características de parque urbano, distintas do parque natural municipal previsto no SNUC ( $§ 4^{\circ}$ do art. 11 da Lei do SNUC).

Entretanto, os parques ecológicos paulistas carecem de regulamentação por diploma legal específico. Por sua vez o regime jurídico dos parques ecológicos de usos múltiplos do distrito federal é bastante convencional, sem nenhuma daquelas características de unidade de conservação previstas no SNUC.

\subsubsection{Sistemas estaduais de unidades de conservação}

Acre: instituído pela Lei 1.426 , de 27/12/2001, este sistema, denominado Sistema Estadual de Áreas Naturais Protegidas (SEANP), difere do SNUC na medida em que suprime as categorias refúgio de vida silvestre, área de relevante interesse ecológico, reserva de fauna e reserva de desenvolvimento sustentável e cria as novas categorias estrada-parque e rio-parque, além de definir um novo grupo, o de unidades de conservação provisória ( $\$ 5^{\circ}$ do art. 17 e arts. 18 a 23 do referido diploma legal) (ACRE, 2001, p. 01-03).

Estrada-parque é uma área natural ou seminatural, de alto valor para conservação, contígua a rodovia. Rio-parque é uma área natural ou seminatural, de alto valor para conservação, contígua a rio, ou porção de rio, preservada na sua condição de mata. Estas unidades podem ser classificadas como de proteção integral ou de uso sustentável, dependendo das características apresentadas (art. 18 da Lei $1.426 / 2001)$. 
Já as unidades de conservação provisória são áreas reservadas e protegidas de forma integral por até cinco anos, renováveis por igual período, uma única vez, a fim de que sejam realizados estudos científicos com o intuito de embasar a definição sobre o uso final ou a categoria definitiva a que corresponda ( $\S 5^{\circ} \mathrm{do}$ art. 17 da Lei 1.426/2001).

Amapá: instituído pelo art. 21 da Lei Complementar 05, de 18/08/1994, que cria o Código de Proteção ao Meio Ambiente, porém não implementado até hoje, já que este dispositivo não foi regulamentado (AMAPÁ, 1994).

Amazonas: criado pela Lei Complementar 53, de 05/06/2007, o Sistema Estadual de Unidades de Conservação possui três categorias distintas das do SNUC: reserva particular de desenvolvimento sustentável (art. 15, inc. VII), estrada parque (art. 15, inc. VIII) e rio cênico (art. 15, inc. IX), todas integrantes do grupo de uso sustentável (AMAZONAS, 2007).

A reserva particular de desenvolvimento sustentável é uma área privada, criada voluntariamente pelo proprietário e gravada com perpetuidade, podendo ou não conter população usuária, com o objetivo de promover a conservação da natureza e o desenvolvimento sustentável por meio de uso direto dos recursos naturais (art. 22).

A estrada parque pode abranger áreas de domínio público ou privado e sua criação compreenderá o leito de parte ou totalidade de uma estrada, as faixas de servidão administrativa de notável valor panorâmico, cultural ou recreativo, ou de importância para a preservação dos seres vivos e pressupõe: expressiva beleza cênica, florística e importância faunística; ocorrência ou perspectiva de expressivo fluxo de turistas e visitantes; existência de alguma infra-estrutura e a possibilidade de implementação de melhorias. Ao longo da estrada parque, o poder público deve incentivar o turismo sustentável e a educação ambiental (art. 23 , incs. I a III e $§ 2^{\circ}$ ).

Constituem objetivos básicos de manejo da estrada parque: promover o desenvolvimento turístico e viabilizar o desenvolvimento social e econômico das comunidades tradicionais; assegurar a preservação e a valorização do patrimônio cultural e natural; fixar normas de uso e ocupação do solo; prevenir ou corrigir 
eventuais distorções do uso do solo, causadas pela realização presente ou iminente de obras públicas ou privadas, ou pelo parcelamento e ocupação do solo; a implantação de efetivas medidas que assegurem a preservação do equilíbrio ambiental e a proteção ao patrimônio cultural e natural nela existentes, a fim de regular os fluxos de turistas e visitantes e as atividades, obras e serviços permissiveis ( $§ 5^{\circ}$ do art. 23 ).

Bahia: o Sistema Estadual de Unidades de Conservação foi instituído pela Lei 10.431, de 20/12/2006 (SOCIEDADE MUNDIAL DE PROTEÇÃO ANIMAL, 2006) que dispõe sobre a política de meio ambiente e de proteção à biodiversidade estadual. Este sistema prevê três categorias que não fazem parte do SNUC: parques urbanos; horto florestal e jardins botânico, zoológico e zoobotânico e reserva particular de proteção da biodiversidade, todas unidades de conservação de uso sustentável (art.74, inc. II, letras $\underline{\text { ha }}$ i).

Parques urbanos são espaços abertos destinados ao lazer, educação, saúde da população e à conservação dos recursos ambientais, considerando-se, para sua criação, os atributos naturais, culturais, sociais, históricos, paisagísticos e cênicos $(\S$ $1^{\circ}$ do art. 74).

Horto florestal e os jardins botânico, zoológico e zoobotânico são áreas destinadas à proteção e manutenção de coleção de plantas e animais vivos em cativeiro ou semicativeiro, visando à perpetuação das espécies, permitida a visitação pública $\left(\S 2^{\circ}\right.$ do art. 74$)$.

Reserva particular de proteção da biodiversidade é a área de domínio particular, individual ou coletivo, reconhecida por autoridade competente, onde o proprietário, por período não inferior a quinze anos, protege os valores dos recursos ambientais para uso futuro, cujos critérios para o seu reconhecimento e uso serão definidos em regulamento ( $\left(3^{\circ}\right.$ do art. 74$)$.

A reserva particular de proteção de biodiversidade, o horto florestal e jardins botânico, zoológico e zoobotânico podem ser criados sem consulta pública prévia ( $\S 3^{\circ}$ do art. 79 ). A existência de zona de amortecimento é dispensada no caso 
da reserva particular de proteção de biodiversidade e opcional no caso de horto florestal, jardins botânico, zoológico e zoobotânico (art. 80).

Goiás: foi instituído pela Lei 14.247, de 29/07/2002 e mantém as mesmas categorias do SNUC, com exceção da reserva biológica e da reserva extrativista que foram suprimidas (GOIÁS, 2002).

Maranhão: instituído pela Medida Provisória 12, de 14/09/2006 que dispõe sobre a política florestal e de proteção à biodiversidade. Este sistema suprime as categorias reserva de desenvolvimento sustentável e reșerva da fauna e copia as demais integrantes do SNUC. Está prevista a possibilidade de criação de outras unidades de conservação desde que definidas em lei pelo poder público (arts. 21 , inc. VI e 22, inc. VI) (MARANHÃO, 2006).

Mato Grosso: instituído pelo Decreto 1.795, de 04/11/1997, que regulamenta o art. 32 da Lei Complementar 36, de 21/11/1995 (Código Estadual de Meio Ambiente) (MATO GROSSO, 1997). Não acolhe as categorias área de relevante interesse ecológico, reserva de fauna e reserva de desenvolvimento sustentável. Cria a unidade estrada-parque, definida como área de domínio público ou privado, compreendendo as rodovias e suas margens de alto valor panorâmico, cultural ou recreativo (art. 21). Cria ainda a denominada reserva de recursos naturais, unidade de conservação de manejo provisório, que visa assegurar temporariamente a proteção parcial dos atributos naturais até que estudos técnico-científicos indiquem a melhor destinação para a área protegida (art. 22, caput). Nessa categoria admite-se a exploração de parte dos recursos disponíveis em regime de manejo sustentável, sujeito às limitações legais ( $§$ único do art. 22).

Num primeiro momento, tendo em vista a omissão do texto regulamentar, tem-se a impressão que o SEUC mato-grossense não admite a reserva particular do patrimônio natural. Porém ela foi instituída na esfera estadual pelo Decreto 5.436, de 12/1 1/2002 (MATO GROSSO, 2002).

Minas Gerais: o SEUC foi criado pela Lei 14.309 , de 19/06/02. Segue as linhas gerais das categorias SNUC, apenas com a supressão das categorias reserva de 
desenvolvimento sustentável e reserva de fauna. Os arts. 23 , inc. VI e 24 , inc. VI dessa lei prevêem a criação de outras categorias desde que definidas em lei pelo poder público (MINAS GERAIS, 2002).

Rio Grande do Norte: instituído pela Lei Complementar 272, de 03/03/2004 (RIO GRANDE DO NORTE, 2004), copia as categorias do SNUC, porém com uma circunstância agravante: a criação de uma unidade de conservação só pode ocorrer por meio de lei (art. 18).

Este dispositivo suplementar estadual é inconstitucional, eis que contraria a norma geral federal, qual seja o art. 22 da Lei do SNUC, que permite a criação de unidades de conservação por qualquer ato do poder público, colidindo, por conseqüência, com o $\S 1^{\circ}$ do art. 24 da Constituição Federal.

Além disso, a lei potiguar termina por ser mais permissiva que a lei federal, no que tange à proteção ambiental, já que dificulta a criação de unidades de conservação. E CUSTÓDIO (2005, p.339) informa que no âmbito da competência suplementar dos Estados, devem prevalecer sempre as disposições de natureza mais restritiva, isto é, a lei estadual deve ser mais protetiva do meio ambiente do que a federal.

Rio Grande do Sul: a existência de um Sistema Estadual de Unidades de Conservação já era previsto no art. $3^{\circ}$, inc. I da Lei 9.519 que instituiu o Código Florestal Estadual em 21/0I/1992 (RIO GRANDE DO SUL, 1992). A regulamentação do SEUC ocorreu pelo Dec. 34.256, de 02/04/1992 (RIO GRANDE DO SUL, 1992), alterado pelo Dec. 38.814, de 26/08/1998 (RIO GRANDE DO SUL, 1998), cujo art. 12 recebeu nova redação pelo Dec. 39.414 , de 15/04/1999 (RIO GRANDE DO SUL, 1999).

O SEUC gaúcho cria um grupo de unidades de conservação de manejo provisório cujo objetivo básico é assegurar, temporariamente, a preservação integral do ambiente, até que estudos técnico-científicos indiquem seu uso adequado. Neste grupo existe apenas uma categoria denominada reserva de recursos naturais, que é uma área de domínio público, desabitada ou pouco habitada que, por falta de 
definição sobre o uso da terfa e de seus recursos, convém preservar até que pesquisas e critérios sociais, econômicos e ecológicos indiquem seu uso adequado (art. 12, inc. II do Dec. 38.614/1998, com a redação dada pelo Dec. 39.414/1999).

Dentro do grupo de unidades de conservação de uso sustentável deste SEUC existem três categorias não previstas no SNUC: a estrada-parque, o horto florestal e o jardim botânico.

A estrada-parque é um parque linear, sob administração pública, de alto valor panorâmico, cultural, educativo e recreativo. As margens, em dimensões variáveis, são mantidas em estado natural ou semi-natural, não sendo necessária a desapropriação, mas, somente, o estabelecimento de normas quanto ao limite de velocidade, pavimentação, sinalização e faixa a ser protegida (art. 12, inc. III do Dec. 38.614/1998, com a redação dada pelo Dec. 39.414/1999)

O horto florestal é uma área de domínio público ou privado, caracterizada pela existência de culturas florestais nativas ou exóticas, passíveis de exploração racional através de manejo sustentado. Constituem-se em centros de pesquisa e bancos genéticos, onde é altamente recomendado, sob zoneamento, o cultivo, a conservação e a recomposição de populações nativas vegetais ou animais, bem como o ensino, a educação ambiental e o lazer (idem).

O jardim botânico é uma área de domínio publico ou privado, com o objetivo de manejo visando a conservação ex-situ de coleções de plantas, a pesquisa científica, o lazer e a educação ambiental (idem).

Rondônia: instituído pela Lei 1.144 , de $22 / 12 / 2002$, ele mantém todas as categorias previstas no SNUC, com exceção da reserva de desenvolvimento . sustentável que foi suprimida (RONDÔNIA, 2002).

Santa Catarina: criado pela Lei 11.986 de 12/11/2001, este SEUC em nada inovou. Apenas copia todas as categorias de unidades de conservação previstas no SNUC (SANTA CATARINA, 2001). 
Sergipe: foi criado pela Lei 5.858, de 22/03/2006 e copia todas as categorias do SNUC. Inova, no entanto, ao reconhecer como unidades de conservação atípicas as áreas de preservação permanente, reserva legal, servidões florestais, reserva da biosfera, horto, jardim zoológico, jardim botânico e áreas de uso especial (art. 68, inc. II). A única dessas categorias que mereceu uma definição específica foi a área de uso especial: área com atributos especiais de valor ambiental e cultural, protegida por instrumentos legais ou não, na qual o poder público estadual pode estabelecer normas específicas de utilização para garantir sua conservação (art. 12, inc. VII) (SERGIPE, 2006).

Tocantins: este SEUC, criado pela Lei 1.560 de 05/04/2005, exclui do rol de suas categorias a reserva biológica e a floresta nacional. Por outro lado inclui, entre as unidades de uso sustentável, o rio cênico e a estrada-parque (TOCANTINS 2005).

Rio cênico é uma unidade de conservação em forma de faixas lineares em áreas de domínio público ou privado, compreendendo a totalidade ou parte de um rio, com notável valor panorâmico, cultural ou recreativo, incluindo como limites os leitos e todas as terras adjacentes essenciais para a integridade paisagística e ecossistêmica. O poder públiço deve incentivar o turismo sustentável e a educação ambiental ao longo do rio cênico (art. 26).

A estrada-parque, por sua vez, é instituída compreendendo o leito de parte ou totalidade da estrada e as faixas de domínio de notável valor panorâmico, cultural ou recreativo. O turismo sustentável e a educação ambiental devem ser incentivados ao longo das estradas-parque (art. 27 , caput e $\S 2^{\circ}$ ).

Observados os diversos sistemas estaduais de unidades de conservação, temos que os estados têm sido muito tímidos no exercício de sua competência constitucional supletiva, no sentido de criar categorias de unidades de conservação em sentido amplo que venham a preencher lacunas do SNUC, especialmente no que tange à proteção das áreas verdes urbanas.

Destarte, grande parte dos sistemas estaduais resume-se a copiar as categorias previstas no SNUC, quando muito suprimindo algumas delas: Goiás, 
Maranhão, Minas Gerais. Rio Grande do Norte, Rondônia, Santa Catarina. Entretanto, os sistemas estaduais maranhenses e minérios prevêem a possibilidade de criação de novas categorias por lei. Já o sistema estadual do Amapá sequer foi efetivado. E o do Sergipe, ao criar a área de uso especial não inovou, já que esta categoria é bastante semelhante à área de proteção especial, mencionada acima.

Os Estados do Acre, Mato Grosso e Rio Grande do Sul criaram unidades de conservação de manejo provisório, de suma importância, como já nos referimos ao comentar anteriormente a reserva estadual paulista.

O Estado da Bahia, por sua vez, inova ao criar a reserva particular de proteção da biodiversidade como unidade de manejo provisório de domínio privado.

As categorias estrada-parque e rio cênico (ou rio-parque) são comuns a diversos sistemas estaduais: Acre, Amazonas, Mato Grosso, Rio Grande do Sul e Tocantins. Sua importância reside em buscar proteger as margens de estradas e de rios, dotadas de notável beleza paisagística, em razão da qual ficam especialmente ameaçadas pelo turismo indiscriminado e predatório.

O horto florestal surge na Bahia e no Rio Grande do Sul. Neste último Estado ele é mais bem definido, inovando pela possibilidade de exploração racional, através de manejo sustentado, de culturas florestais nativas ou exóticas, além de pesquisa científica, educação ambiental e lazer. Distingue-se da floresta nacional na medida em que não se exige cobertura vegetal de espécies predominantemente nativas. E ainda pelo fato de se admitir em sua área o cultivo de espécies nativas ou exóticas.

Cumpre ressalvar que o Estado de São Paulo também previa a existência da categoria horto florestal. Porém ela vem sendo reclassificada, de acordo com o SNUC. Destarte, o horto florestal situado em Rio Claro-SP, teve sua denominação mudada para floresta estadual, muito embora sua cobertura vegetal predominante seja de eucaliptos. Talvez fosse melhor manter a denominação original e integrar o horto florestal num possível sistema estadual de unidades de conservação. 
A reserva particular de desenvolvimento sustentável, do Amazonas, assume especial relevância ao possibilitar em área privada o uso sustentável direto dos seus recursos naturais. O Amazonas assim recupera a proposta original da reserva de particular do patrimônio natural (RPPN), que foi convertida em unidade de conservação de proteção integral pelo veto presidencial ao inc. III do art. 21 da Lei do SNUC.

Tal categoria merece elogios, na medida em que a possibilidade de exploração sustentável, de pelo menos parte da área, aumenta bastante a possibilidade de criação de unidades de conservação de domínio privado, ao permitir a amortização pelo proprietário de pelo menos parte das despesas com a elaboração de plano de manejo, manutenção e vigilância da área, que, diga-se de passagem, não são nada modestas.

O jardim zoológico, o jardim zoobotânico (Bahia) e o jardim botânico (Bahia e Rio Grande do Sul) assumem importância por serem áreas protegidas de preservação ex situ consideradas como unidades de conservação.

Por fim, merece ainda especial destaque, tendo em vista o escopo deste trabalho, o Estado da Bahia por seu sistema estadual ter sido o único de sua esfera a acolher uma categoria de unidade de conservação urbana, no grupo de uso sustentável: os parques urbanos.

E o regime jurídico dos parques urbanos baianos, idêntico ao das demais unidades de conservação estaduais, na conformidade da Lei 10.431, de 10/12/2006, prevê conselho gestor com representantes da sociedade civil (art. 76); criação por qualquer ato do poder público, precedido de estudos técnicos e consulta pública (art. 79 , caput e $\S \S 1^{\circ}$ e $3^{\circ}$ ); zona de amortecimento, quando necessária ( $\S$ único do art. 80); plano de manejo, abrangendo a zona de amortecimento (art. 83); além da possibilidade de gestão por organizações da sociedade civil com objetivos afins aos da unidade (art. 86).

Portanto o parque urbano baiano tem um tratamento jurídico semelhante às unidades de conservação integrantes do SNUC, o que é muito salutar. 
4.3.2.3. Sistemas municipais de unidades de conservação

Pode o Município criar um sistema próprio de unidades de conservação? E este sistema pode contemplar unidades de conservação em sentido amplo, distintas daquelas contidas no SNUC e na legislação do Estado em que se situa?

Como vimos acima, pelo art. 24, incs. VI, VII e VIII, a Constituição Federal consagra a competência concorrente entre União, Estados e Distrito Federal para legislar sobre meio ambiente, natural e cultural. Porém, esse dispositivo legal não faz referência alguma aos Municípios, fazendo crer, à primeira vista que eles não tenham competência legislativa para tratar do meio ambiente.

Porém observamos que tal não ocorre, tendo em vista os incs. I e II do art.30 que informam competir aos Municípios legislar sobre assuntos de interesse local e suplementar a legislação federal e estadual no que couber.

Pela Constituição de 1988, de acordo com FARIAS (1999, p.296-297), os Municípios passam a ter autonomia e competência legislativa mínima rigidamente estabelecida. A questão envolve parte desta competência que depende do fluido conceito de interesse local.

O mesmo FARIAS (1999, p.298-299), citando Diogo de Figueiredo Moreira Neto, Sampaio Dória e Michel Temer, conclui que interesse local deve ser tratado como expressão idêntica a peculiar interesse, que vinha sendo utilizada pelo art. 15, inc. II da Constituição de 1967, com a redação que lhe deu a Emenda 01 de 17/10/1969. E ainda que local ou peculiar não significa privativo, que importaria em exclusão. $\mathrm{O}$ interesse dos Municípios é entrelaçado com os interesses dos Estados e da União. O que os diferencia é a predominância e não a exclusividade. Ou seja, o que define o interesse local é a predominância do interesse do Município sobre o do Estado ou o da União. 
Segundo SILVA, J. A. (2007b, p.79-80), a competência municipal para legislar supletivamente em matéria ambiental também é constitucionalmente reconhecida. De fato os municípios têm competência para promover o adequado ordenamento territorial, mediante planejamento e controle do uso, parcelamento e ocupação do solo urbano (art. 30, inc.VIII), para executar a política de desenvolvimento urbano e estabelecer plano diretor (art. 182) e ainda para promover a proteção do patrimônio histórico-cultural local, observadas a legislação e a ação fiscalizadora federal e estadual (art. 30 inc. IX). Isto significa que não se recusa aos municípios competência para ordenar a proteção do meio ambiente, natural e cultural. Logo é plausível reconhecer, igualmente, que na norma do art. 30, inc. II, entra também a competência para suplementar a legislação federal e a estadual na matéria.

A competência suplementar do Municipio encontra-se disposta no art. 30, inc. II da Constituição Federal, que estabelece que aos Municípios compete suplementar a legislação federal e estadual no que couber. De acordo com MATTOS NETO (1999, p.129), para que o Município suplemente, quer dizer, complemente ou supra norma federal ou estadual, só pode haver ingerência em matérias nas quais a competência da União ou Estado-membro não seja exclusiva e privativa, mas concorrente. E a competência constitucional concorrente das entidades está consagrada no art. 24 da Lei Básica, entre as quais encontramos a matéria ambiental.

Adiante, o mesmo autor (1999, p.132) informa que a competência municipal para legislar sobre meio ambiente é traçada a partir da conjugação do interesse local com o caráter suplementar que lhe empresta o constituinte para suprir ou complementar a lei federal ou estadual. Quando a suplementação é necessária para regular um interesse local, aí temos a caracterização constitucional da expressão no que couber, que exige o Constituinte para a lei municipal ser válida.

Em hábil síntese, SIRVINSKAS (2008, p.119) informa que nada obsta que os Municipios legislem sobre as matérias arroladas no art. 24 da Constituição Federal (entre as quais se inclui a matéria ambiental), desde que esteja presente o seu interesse peculiar ou local. Essa permissão está prevista no art. 30, incs. I e II, da 
Constituição Federal, podendo o Município suplementar, no que couber, as legislações federal e estadual dentro do seu próprio interesse. Os Municípios não podem legislar plenamente fundados em seu interesse local, desrespeitando as normas federais e estaduais. .

No mesmo sentido BARROSO (2008, p.121) afirma que a competência legislativa sobre matéria ambiental dos Municípios estará restrita ao tratamento de assuntos de interesse local (art. 30, inc. I, da Constituição Federal) e à eventual complementação da legislação federal e estadual (art. 30, inc. II, da Constituição Federal) em função de eventuais peculiaridades da municipalidade.

MORAES (2006, p.57-58) declara que aos Municípios, como também aos Estados, resta o campo das regras especiais, divididas em concorrentes e suplementares. A concorrente pura é aquela cuja matéria não necessite de regra geral, pois o objeto jurídico protegido é tão especial que não existe em outras regiões. A suplementar, de forma contrária, está atrelada à legislação ampla, a qual, em razão da existência de peculiaridade, necessita adaptação para aquela parcela do território nacional, sendo premissa básica dessa regulamentação sua existência para a manutenção do bem jurídico nessa parcela do território, sem a qual o objeto de proteção legal pereceria.

Enfático, BESSA (2007, p.85) afirma que o meio ambiente está incluído no conjunto de atribuições legislativas e administrativas municipais e, em realidade, os Municípios formam um èlo fundamental na complexa cadeia de proteção ambiental. A importância dos Municípios é evidente por si mesma, pois as populações e as autoridades locais reúnem amplas condições de bem conhecer os problemas e mazelas ambientais de cada localidade, sendo certo que são as primeiras a localizar e identificar o problema. É através dos Municípios que se pode implementar o princípio ecológico de agir localmente, pensar globalmente. $\mathrm{Na}$ verdade, entender que os Municípios não têm competência ambiental específica é fazer uma interpretação puramente literal da Constituição Federal. 
Conforme AGUIAR (2002, p.196), o Superior Tribunal de Justiça manifestou o entendimento de que "é competência comum à União, Estados e Municípios proteger o meio ambiente e combater a poluição, cabendo aos Municípios legislar supletivamente sobre a proteção ambiental, na esfera do interesse estritamente local. A legislação municipal, contudo, deve se restringir a atender às características próprias do seu território. REsp 29.299-RS, $1^{\text {a }}$ T., Min. Demócrito Reinaldo".

Ressalta LEUZINGER ( 2002, p.131) que em se tratando de normas de preservação ambiental, não se pode ignorar que o aspecto suplementar diz respeito exclusivamente ao caráter mais restritivo da norma municipal, não sendo admitido pelo sistema aquela que contrarie ou deturpe a finalidade e conteúdo das normas federais e estaduais, visto que a exacerbação da competência municipal significaria, muitas vezes, o sacrifício da proteção e defesa do meio ambiente constitucionalmente previstos.

À luz dos $\S \S 1^{\circ}$ e $4^{\circ}$ do art. 24, do art. 225 da Constituição Federal, bem como em razão da indefinição do que seja norma especial, FARIAS (1999, p.356) expressa que se deve fixar como diretriz exegética que os eventuais conflitos, onde a noção de norma geral e especial não seja suficiente, serão resolvidos pela prevalência da norma que melhor defenda o direito fundamental tutelado, por tratar-se de preceito constitucional que se impõe à ordem jurídica central ou regional. Assim, o princípio in dubio pro natura deve constituir um princípio inspirador da interpretação. Isto significa que, nos casos em que não for possível uma interpretação unívoca, a escolha deve recair sobre a interpretação mais favorável à proteção ambiental.

No art. 23, incs. III, IV, VI e VII da Constituição Federal, encontramos também a proteção do meio ambiente, seja natural ou cultural, como competência comum de todos os entes federativos, inclusive do Município.

Para SILVA (2007b, p.79) e BESSA (2007, p.84), a competência comum é apenas administrativa, para praticar ações materiais e não para legislar. 
Para MILARÉ (1999, p.42), não se pode olvidar que o princípio da legalidade está entre os basilares da administração pública. Assim, o exercício do poder de polícia pela administração deve ater-se à lei. Ora, continua o mesmo autor, na medida em que a Constituição Federal deferiu determinadas competências administrativas às três esferas federativas, conferiu-lhes implicitamente competência para legislar sobre as mesmas matérias, sempre que necessário, ou seja, quando um determinado ordenamento jurídico for insuficiente. Por conseguinte, sempre que houver interesse local, ou o ordenamento jurídico for insuficiente, o Município pode legislar sobre qualquer das matérias referidas no art. 23 , já que só assim poderá exercer sua competência administrativa.

Em resumo, aos Municípios cabem as mesmas observações feitas acima com relação aos Estados e Distrito Federal. Respeitadas as normas gerais da Lei do SNUC e eventual legislação estadual existente sobre o tema, o Município pode criar categorias de unidades de conservação em sentido amplo próprias, isto é, distintas daquelas do SNUC, com a finalidade de atender as suas necessidades peculiares e locais, as quais devem ter denominação diferente daquelas arroladas na lei federal. Essas categorias, por sua vez, podem ser integradas em "sistemas municipais de unidades de conservação".

E esses sistemas municipais podem muito bem incluir unidades de conservação de caráter urbano. Neste aspecto, a competência municipal é reforçada pelo disposto no art. 30, inc. VIII da Constituição Federal. Por força de tal dispositivo, cabe frisar, é de competência municipal promover, no que couber, adequado ordenamento territorial, mediante planejamento e controle do uso, do planejamento e da ocupação do solo urbano. Obviamente, a criação de parques urbanos, por tudo de positivo que representa para o meio ambiente, saúde e lazer da população, constitui-se em importante instrumento para a adequação do uso do solo urbano.

No entanto, se os Estados já demonstram excessiva timidez no exercício de sua competência constitucional de suplementar o SNUC, os Municípios 
conseguem se mostrar ainda menos ativos. Ou os Municípios não instituem sistema nenhum ou copiam integralmente o SNUC.

Desconhecimento, comodismo, falta de estrutura técnica, receio de invadir competência estadual ou federal, diante das dificuldades em se determinar com precisão a competência legislativa dos Municipios. São todos fatores que podem inibir a atuação municipal na implantação de sistemas de unidades de conservação próprios. Mas talvez o maior motivo, pelo menos no que tange aos municípios menores, seja o "ICMS ecológico".

A Constituição Federal, em seu art. 158, inc. IV, prevê que $25 \%$ dos recursos financeiros do imposto sobre circulação de mercadorias e serviços (ICMS) arrecadados por cada Estado devem ser destinados aos seus Municípios. A Constituição Federal também estipula, no inc. I do $\S$ único do mesmo art. 158, que no mínimo $75 \%$ do montante repassado aos Municípios deve ser distribuído segundo o valor adicionado gerado. em cada Município, isto é, na proporção do que cada um deles arrecada. Por sua vez, os restantes $25 \%$, ou seja, $6,25 \%$ do total arrecadado, podem ser creditados conforme critérios determinados em lei estadual (inc. II do $\S$ único do citado art. 158). Isto permite a cada Estado influir nas prioridades dos Municípios, incentivando certas atividades e desencorajando outras. E é sobre esses $6,25 \%$ do total arrecadado que o Estado pode decidir como redistribuir, que critérios ecológicos foram introduzidos para fundamentar o repasse. E assim surgiu o denominado ICMS ecológico (BENSUSAN, 2006, p.52).

Criado pioneiramente no Paraná, em 1991, foi adotado também em nove Estados e está em debate ou com anteprojetos de lei em tramitação nas respectivas casas legislativas de outros sete Estados [julho de 2008] (LOUREIRO).

Nascido sob o argumento da compensação financeira aos Municípios que possuíam restrição do uso do solo em seus territórios para o desenvolvimento de atividades econômicas clássicas, o ICMS ecológico tinha tudo para se transformar numa ferramenta estéril, acrítica, uma espécie de "chancelador" puro e simples para o repasse de recursos (LOUREIRO). 
Mas acabou por tornar-se um incentivo, já que, por força da metodologia adotada, pelo menos no Paraná, acabou por estimular os Municípios que não possuíam unidades de conservação a criar ou defender a criação destas. E ainda estimular aqueles Municípios que já as possuíam a tomar parte em iniciativas relacionadas à regularização fundiária, planejamento, implementação e manutenção das unidades de conservação (LOUREIRO).

No caso paranaense, entre 1992 e 2000, houve um incremento de $1.894,94 \%$ em superfície de unidades de conservação municipais. Houve ainda melhoria na qualidade da conservação das unidades de conservação estaduais, municipais e das RPPNs (LOUREIRO).

Apesar do sucesso, as lei estaduais do "ICMS ecológico" geralmente condicionam o repasse à criação ou manutenção de unidades de conservação segundo a tipologia do SNUC. E o Município, necessitado de receber o repasse de verba, termina por abrir mão de sua competência suplementar. Isto é, ou institui um sistema municipal que é mera cópia do nacional, ou nem mesmo isso, limitando-se a criar em seu território unidades de conservação isoladas, conforme as categorias arroladas no SNUC.

E assim o Município, que é o principal gestor constitucional das áreas urbanas, deixa de zelar pelo meio ambiente urbano e passa a concentrar seus esforços na preservação ambiental rural.

Para ilustrar esse tema, localizamos quatro sistemas municipais de unidades de conservação, razoavelmente estruturados, relativos a capitais estaduais. Dois deles já se encontram legalmente instituídos, o de Curitiba e o de Manaus. Quanto aos outros dois, o de Porto Alegre está na fase de projeto de lei e o de Goiânia ainda é uma minuta de projeto de lei.

O Sistema de Unidades de Conservação do Município de Curitiba foi criado pela Lei 9.804 de 03/01/2000 (CURITIBA, 2000), portanto poucos meses antes da promulgação da Lei do SNUC. Ela define como unidades de conservação as áreas no Município, de propriedade pública ou privada, com características naturais 
de relevante valor ambiental ou destinadas ao uso público, legalmente instituídas, com objetivos e limites definidos, sob condições especiais de administração e uso, às quais se aplicam garantias de conservação, proteção ou utilização pública (art. $2^{\circ}$ ).

Este sistema contempla nove categorias de unidades de conservação (art.3):

(I) áreas de proteção ambiental: áreas de domínio público ou privado, sobre as quais-se impõem restrições às atividades ou uso da terra, visando a proteção dos corpos d'água, vegetação ou qualquer outro bem de valor ambiental definido pela Secretaria Municipal de Meio Ambiente;

(II) parques de conservação: áreas de domínio do Município destinadas à proteção dos recursos naturais existentes, que possuam dimensão mínima de dez hectares e que se destinem à manutenção da qualidade de vida e proteção do interesse comum de todos os habitantes;

(III) parques lineares: são áreas de domínio público ou privado, ao longo dos corpos d'água, em toda a sua extensão ou não, que visam garantir a qualidade ambiental dos fundos de vale, podendo conter outras unidades de conservação dentro de sua área de abrangência;

(IV) parques de lazer: são áreas de domínio do Município, que possuam dimensão mínima de dez hectares e que se destinem ao lazer da população, comportando equipamentos para a recreação e com características naturais de interesse para proteção;

(V) reservas biológicas: são áreas de domínio publico ou privado, que possuam características representativas do ambiente natural do Município, com dimensão variável e que se destinem à preservação e à pesquisa científica;

(VI) bosques nativos relevantes: são bosques de mata nativa representativos da flora do Município, em áreas de domínio privado, 
que visam a preservação das águas existentes, do habitat da fauna, a estabilidade dos solos, a proteção paisagística e a manutenção da distribuição equilibrada dos maciços vegetais, onde o Município impõe restrições à ocupação do solo;

(VII) bosques de conservação: são áreas de domínio do Município, destinadas à proteção dos recursos naturais existentes, que possuam dimensão menor que dez hectares e que se destinem à manutenção da qualidade de vida e proteção do interesse comum de todos os habitantes;

(VIII) bosques de lazer: são áreas de domínio do Município com dimensão inferior a dez hectares, destinadas à proteção de recursos naturais com predominância de uso publico ou lazer;

(IX) específicas: são unidades de conservação criadas para fins e objetivos especificos, tais como: jardim botânico, pomar público, jardim zoológico e nascentes.

A lei ainda prevê que as unidades de conservação serão estabelecidas e terão suas características, objetivos e peculiaridades definidas através de ato do executivo municipal $\left(\S 1^{\circ}\right.$, do art. $3^{\circ}$ ). Prevê ainda a possibilidade de criação por regulamentação especifica de novas categorias de unidades de conservação, como praças, jardinetes, jardins ambientais, largos, eixos de animação e núcleos ambientais $\left(\S 2^{\circ}\right.$, do art. $\left.3^{\circ}\right)$.

Está prevista também a possibilidade de ampliação da área das unidades de conservação existentes, ou implantação de novas, através de compra, desapropriação, permuta por outro imóvel, transferência de potencial construtivo ou condições especiais de ocupação para a área remanescente, no caso de cessão de parte deste imóvel (arts. $4^{\circ}$ e $6^{\circ}$ ). A transferência de potencial construtivo e as condições especiais de ocupação de remanescente de imóvel devem ser objeto de regulamentação específica ( $\S$ único do art. $4^{\circ}$ ). 
A implantação de novas unidades de conservação deve seguir a distribuição estratégica constante em mapa anexo à lei $\left(\right.$ art. $\left.5^{\circ}\right)$.

A Secretaria Municipal de Meio Ambiente deve desenvolver um plano de manejo específico para cada unidade de conservação existente ou que venha a ser criada $\left(\operatorname{art} .7^{\circ}\right)$.

Esta lei deveria ter sido regulamentada no prazo de noventa dias contado a partir de sua publicação (art. $8^{\circ}$ ), o qual está de há muito esgotado. Ao contrário, atualmente tramita pela Secretaria Municipal do Meio Ambiente a proposta de um novo projeto de lei que adaptaria os dispositivos do atual diploma legal à Lei do SNUC.

Merece destaque, fora do Sistema Municipal, a criação da categoria da Reservas Particulares do Patrimônio Natural Municipal de Curitiba, pelo Dec. 606 de 04/06/2007. Esta categoria é bastante semelhante às Reservas Particulares do Patrimônio Natural do SNUC, porém sua implantação deve ocorrer fundamentalmente no meio urbano.

O Sistema Municipal de Unidades de Conservação de Curitiba é um dos mais audaciosos do ordenamento brasileiro, na medida em que busca exercer a competência constitucional legislativa municipal suplementar em sua plenitude. Cria uma série de categorias expressamente denominadas unidades de conservação, distintas daquelas do SNUC, em grande parte voltadas especialmente para o meio urbano, todas com plano de manejo próprio. E ainda contém em seu bojo um plano estratégico de criação de novas unidades.

É certo que algumas definições das categorias de unidades de conservação são um pouco imprecisas e poderiam ser melhoradas. Como também a definição de reserva biológica precisa ser mudada, pois é muito diferente daquela prevista na Lei do SNUC. Também seria interessante tratar das zonas de amortecimento e acrescentar algumas das categorias que constam da Lei do SNUC. Igualmente poderia ser melhor tratada a questão da participação popular na gestão das unidades de conservação. 
Porém, suprimir quaisquer das categorias, deixar de considerar as áreas verdes urbanas como unidades de conservação, ou copiar servilmente a Lei do SNUC seria um verdadeiro retrocesso, um desserviço á população curitibana e um mau exemplo para outros Municípios brasileiros, que tendo em vista o prestígio nacional e até internacional de Curitiba, tendem a imitar as suas políticas públicas e de governo, no que têm de certo e também no que têm de errado.

O Sistema Municipal de Unidades de Conservação de Manaus, criado pela Lei 605, de 24 de julho de 2001, que instituiu o seu Código Ambiental (MANAUS, 2001), copia as categorias do SNUC, excluindo reservas extrativistas e florestas nacionais (art. 33, incs. I a X). Uma categoria denominada parque municipal, por estar deslocada do grupo de unidades de proteção integral (art. 33, inc. X), pode dar a impressão inicial de se tratar de parque urbano. Ledo engano, já que pela sua definição temos, na verdade, uma unidade de conservação da categoria parque nacional. E com denominação errada, já que deveria chamar-se parque natural municipal, nos termos do $\S 4^{\circ}$ art. 11 da lei do SNUC.

Conclui-se que os parques urbanos são denominados pela lei de áreas verdes, cujo conceito é o de espaços definidos pelo poder público municipal, com base no memorial descritivo dos projetos de parcelamento do solo urbano, constituídos por florestas ou demais formas de vegetação primária, secundária ou plantada, de natureza jurídica inalienável, destinados à manutenção da qualidade ambiental (art. $5^{\circ}$, inc. XVII).

Seus objetivos são proporcionar a melhoria da qualidade de vida da população e das condições urbanas; garantir espaços destinados à integração, recreação ou lazer da comunidade local, desde que não provoque danos à vegetação nativa; contribuir para as ações de educação ambiental que envolvam a população do entorno (incs. I a III, do art. 37).

As áreas verdes são consideradas apenas espaços territoriais especialmente protegidos e não unidades de conservação (inc. II do art. 31). Por

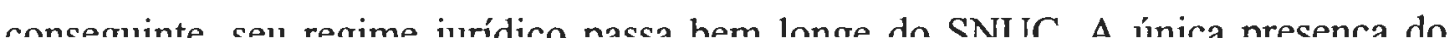


princípio da participação está na possibilidade legal das áreas verdes serem implantadas e/ou protegidas pela sociedade civil organizada ( $\S 1^{\circ}$ do art.37), dispositivo este que necessita de regulamentação.

Também elencados entre os espaços territoriais especialmente protegidos (inc. III, art. 31), estão os fragmentos florestais urbanos, definidos como áreas remanescentes de vegetação nativa situadas dentro do perímetro urbano do Município, em propriedade pública ou privada, que desempenham um papel na manutenção da qualidade do meio ambiente urbano (art. $5^{\circ}$, inc. XVIII).

Absurdạmente, é possível a supressão parcial ou total dos fragmentos florestais urbanos mediante mera autorização do órgão ambiental competente (art. 38, caput), o que é inconstitucional, já que os espaços territoriais especialmente protegidos somente podem ser alterados ou suprimidos mediante lei, de acordo com o inc. III do $\S 1^{\circ}$ do art. 225 da Lei Maior.

O Sistema Municipal de Unidades de Conservação do Porto Alegre ainda está na fase do projeto de lei complementar 005/07 (processo 4.047/07) (PORTO ALEGRE, 2007). Limita-se a copiar as categorias do SNUC, com exceção da floresta nacional e da reserva extrativista. Não manifesta qualquer interesse em implantar uma categoria que seja de unidade de conservação urbana. Marca inclusive um retrocesso em relação ao sistema estadual gaúcho, eis que não menciona entre as suas unidades de conservação o horto florestal e o jardim botânico.

O Sistema Municipal de Unidades de Conservação de Goiânia está ainda na fase de minuta de projeto de lei. Este institui o sistema municipal de unidades de conservação, parques urbanos e áreas verdes de complemento urbano (GOIÂNIA).

Trata-se de um projeto extremamente inovador, na medida em que prevê quatro grupos de unidades de conservação: proteção integral (art. $8^{\circ}$ ), uso sustentável (art. 14), parques urbanos (art. 20) e áreas verdes de complemento urbano (art. 24). Como se vê, ao lado dos dois grupos tradicionais do SNUC, estão mais dois grupos que correspondem às peculiaridades locais de Goiânia. Estes dois grupos locais, 
embora não sejam formalmente denominados unidades de conservação, são legalmente tratados como tal.

Os grupos tradicionais, de proteção integral e uso sustentável, contêm todas as categorias federais, exceto reserva extrativista e reserva de desenvolvimento sustentável. O grupo dos parques urbanos contém três categorias: parque recreativo, parque temático educativo e parque linear. Já o grupo de áreas verdes de complemento urbano comporta outras três categorias: jardim público, praça e área verde de complementação viária. Em nossa análise vamos ater-nos às categorias destes dois últimos grupos.

O objetivo básico dos parques urbanos é tornar compatível a implantação de equipamentos de equipamentos sociais que propiciem o lazer, a educação e o entretenimento à população e a recuperação e preservação de áreas verdes urbanas (§ único do art. 20).

O parque recreativo tem a função social de proporcionar aos cidadãos entretenimento por meio de um espaço urbanizado com equipamentos sociais que permitam atividades contemplativas e culturais e a preservação de áreas verdes. Ele deve ser de posse e domínio públicos e constitui-se em áreas verdes com mais de setenta mil metros quadrados, remanescentes com características naturais alteradas por meio de projetos paisagísticos e urbanísticos (art. 21, caput e $\S 1^{\circ}$ ).

Já o parque temático educativo tem a função social de proporcionar, aos cidadãos, lazer e educação por meio de um espaço urbanizado çom equipamentos sociais que permitam atividades contemplativas, culturais e educativas baseadas em temas de relevância cultural, educativa ou histórica. Ele pode ser constituído por áreas verdes de domínio público ou particular, remanescentes com características naturais alteradas por meio de projetos paisagísticos e urbanísticos (art. 22, caput e $\S 1^{\circ}$ ).

Tanto no parque recreativo como no parque temático em área pública está prevista a existência de plano de manejo. Somente poderão ser admitidas alterações de suas caracteristicas naturais em áreas antropizadas e em conformidade com o 
disposto em regulamento, no plano de manejo e pelo órgão responsável pela sua organização (arts. $21, \S 2^{\circ}$ e $22, \S 2^{\circ}$ ).

No caso do parque temático em área particular, a alteração referida somente pode se efetuada em conformidade com o disposto em regulamento e pelo órgão responsável pela gestão ambiental do município (art. $22, \S 3^{\circ}$ ). O regulamento desta categoria de parque deverá ser analisado a aprovado pelo órgão de gestão ambiental do município (art. $22, \S 6^{\circ}$ ).

Implantado o parque, seja recreativo ou temático educativo, não será admitida a retirada ou alteração dos seus recursos naturais que tenham características nativas (arts. $21, \S 3^{\circ}$ e $22, \S 4^{\circ}$ ).

O parque linear, por sua vez, tem como objetivo recuperar e preservar matas ciliares e os leitos dos córregos, ribeirões e rio do município e oferecer espaços sociais que permitam a preservação dos recursos naturais e a realização de atividades esportivas, educativas, culturais e turísticas. Ele pode ser de posse e domínio público e/ou particular e constitui-se de zonas de proteção ambiental previstas na lei municipal do município, às margens dos córregos, ribeirões e rio de Goiânia (art. 23, caput e $\$ 1^{\circ}$ ).

No parque linear podem ser instalados equipamentos sociais para o lazer e entretenimento desde que obedeçam ao zoneamento estabelecido e sejam implantados com critérios técnicos sustentáveis, conforme orientação do órgão de gestão ambiental municipal (art. $23, \S 2^{\circ}$ ). A implantação de projeto viário para o parque linear deverá contemplar tecnologia sustentável com parâmetros técnicos aprovados pelo órgão de gestão ambiental municipal, destinado a pedestres e meios de transporte alternativos que contribuam para a diminuição dos impactos negativos ao parque e respeitem as dimensões do zoneamento estabelecido (art. $23, \S 3^{\circ}$ ).

A conservação e manutenção das propriedades particulares inseridas em parque linear é de responsabilidade de seus proprietários, cabendo ao poder público dar incentivos por meio de apoio técnico e operacional (art. $22, \S 5^{\circ}$ ). 
Está prevista a criação de conselho consultivo, com participação da sociedade civil organizada, órgãos públicos afins e representantes dos proprietários particulares, para implantação e gestão de cada parque linear ( $\operatorname{art.~} 22, \S 7^{\circ}$ ).

Cada parque urbano deve ter uma zona de amortecimento urbano. Esta compreende as vias públicas, áreas institucionais e imóveis de propriedade particular que se encontram no entorno do parque urbano, onde o uso do solo e as atividades urbanas estão sujeitos a normas e restrições específicas, com o propósito de minimizar os impactos negativos sobre o mesmo (art. 29, caput). Estas zonas de amortecimento terão suas dimensões determinadas no plano de manejo do respectivo parque urbano (art. 29, § único).

Nas vias públicas que circundam os parques urbanos não se admitem shows, comícios ou eventos que provoquem grandes aglomerações de pessoas (art. 30). As edificações residenciais situadas na zona de amortecimento devem ser apenas para habitação unifamiliar (art. 31). As atividades econômicas admitidas são apenas de comércio varejista e prestação de serviços locais (art. 32). As edificações devem garantir permeabilidade do solo de pelo menos vinte e cinco por cento, ter no máximo três pavimentos, não desenvolver atividades industriais e suas fundações não podem prejudicar o lençol freático (art. 33, §único).

A criação de parque público deve ser feita por ato do poder público (art. 39 , caput) e deve ser precedida de estudos técnicos que permitam identificar a localização, a dimensão e os limites mais adequados para a área (art. $39, \S 7^{\circ}$ ). Para a definição dos usos e objetivos de cada parque urbano, deve ser realizada consulta pública (art. 41).

$\mathrm{Na}$ criação dos parques públicos não serão admitidos limites com áreas particulares ou destinadas a atividades públicas institucionais (art. $43, \S 4^{\circ}$ ).

No que tange às áreas verdes de complemento urbano, o jardim público e a praça pública têm os mesmos objetivos e características do parque recreativo. As diferenças resumem-se às dimensões de cada categoria. O parque recreativo, mencionado acima, deve ter mais de setenta mil metros quadrados de área. Por sua 
vez, o jardim público deve ter entre três mil e setenta mil metros quadrados e a praça até três mil metros quadrados de área (arts. $25, \S 1^{\circ}$ e $26, \S 1^{\circ}$ ). Além disso, o jardim público, embora tenha plano de manejo, não possui zona de amortecimento. E a praça pública não possui nenhum dos dois.

O verde de acompanhamento viário tem a função social de proporcionar à cidade um espaço urbanizado com ajardinamentos, canteiros centrais e implantação de equipamentos sociais para atividades contemplativas, com o objetivo de também preservar as áreas verdes (art. 27, caput). Este é de posse e domínio públicos, constituindo-se em áreas verdes de canteiros centrais de ruas e avenidas, pontas de ruas e marginais com dimensões adequadas para implantação de equipamentos sociais e áreas remanescentes com características naturais alteradas por meio de projetos paisagísticos e urbanísticos (art. $27, \S 1^{\circ}$ ). De resto suas características são idênticas àquelas dos jardins públicos e praças.

Em síntese, o projeto de Sistema Municipal de Unidades de Conservação de Goiânia é bem estruturado e bastante avançado para a esfera municipal ao contemplar os parques urbanos e áreas verdes urbanas conexas. Embora não sejam denominados de unidades de conservação, a sua tutela jurídica contempla alguns dos principais institutos do SNUC, como o plano de manejo e a zona de amortecimento. A presença do conselho consultivo com participação da sociedade civil, como instrumento de gestão, surge na categoria parque linear. Até mesmo as divisas de parques públicos com áreas particulares e públicas institucionais são proibidas, já prevendo a tendência que estas duas últimas têm de se assenhorear de espaços daqueles.

É de se observar, no entanto, que o conselho consultivo deveria integrar a gestão de todas as categorias integrantes do grupo dos parques públicos. Deve-se ressaltar também a ausência de previsão legal quanto à possibilidade de gestão por organização da sociedade civil de interesse público. A utilização adequada dessas organizações poderia garantir uma gestão coerente e duradoura para os parques urbanos, sem tanta influência dos ventos políticos. Além disso, para melhor 
administrar, elas poderiam atuar na captação de recursos, inclusive privados, que garantiriam a sustentabilidade econômica dos parques urbanos.

\subsection{UNIDADES DE CONSERVAÇÃO DE PROTEÇÃO INTEGRAL COMO ZONA RURAL: SIGNIFICADO}

4.4.1. Conceitos de zona rural e zona urbana

$\mathrm{O}$ art. 49 da Lei do SNUC determina que a área de uma unidade de conservação do grupo de proteção integral deva ser considerada zona rural para todos os efeitos legais. O seu parágrafo único, por sua vez, prescreve que a zona de amortecimento deste mesmo grupo, uma vez definida formalmente, não pode transformar-se em zona urbana. Numa primeira interpretação, parece que o legislador quis impedir a criação de unidade de conservação de proteção integral em área urbana.

Entretanto, fica difícil captar a intenção do legislador ao elaborar tal dispositivo legal, na medida em que ele não define claramente o significado da expressão "zona rural", nem "zona urbana". 
4.4.2. Conceitos de urbano e rural do ponto de vista das ciências não jurídicas

Urbano significa "relativo à cidade". Cidade, por sua vez, é sinônimo de “urbe” (FERREIRA, 1988, p.659). É possível, no entanto, distinguir-se espaço urbano de cidade. Segundo Santos e Lefebvre, apud CAVALCANTI (2001, p.14), a cidade é a forma, é a materialização de determinadas relações sociais enquanto que espaço urbano é o conteúdo, são as próprias relações sociais que se materializam no espaço. Porém, não se pode fazer uma separação absoluta entre espaço urbano e cidade, assim como numa análise dialética, não se pode fazer uma separação absoluta entre forma e conteúdo: há entre as duas categorias uma relação de interdependência dialética.

Assim sendo, tendo em vista o escopo do presente trabalho, no seu alcance jurídico, não há qualquer impedimento para se tratar "zona urbana" como tendo o mesmo significado que "cidade".

Por sua vez rural significa "relativa ao campo" (FERREIRA, 1988, p.579). Campo significa "zona fora do perímetro urbano ou suburbano" (FERREIRA, 1988, p.121). Isto quer dizer que é necessário conceituar "cidade" (urbano), para, por exclusão, chegar-se ao conceito de "campo"(rural).

Cumpre salientar que embora as expressões "zona urbana" e "zona rural" possam ser entendidas, do ponto de vista jurídico, como "cidade" e "campo", num sentido de oposição recíproca, porém de relativo convívio, importantes autores questionam tal conceito, por eles considerado cientificamente superado. Neste sentido é o entendimento de SANTOS (2005, p.73-74), quando trata da realidade brasileira:

"Graças à evolução contemporânea da economia e da sociedade, e como resultado do recente movimento de urbanização e de expansão capitalista no campo, podemos admitir, de modo geral, que o território brasileiro se encontra, hoje, grosseiramente repartido em dois grandes 
subtipos, que agora vamos denominar de espaços agricolas e espaços urbanos. Utilizando, como um novo sentido, a expressão região, diremos que o espaço total brasileiro é atualmente preenchido por regiões agrícolas e regiões urbanas. Simplesmente, não mais se trataria de "regiões rurais" e de "cidades". Hoje, as regiões agrícolas (e não rurais) contêm cidades; as regiões urbanas contêm atividades rurais. $\mathrm{Na}$ presente situação socioeconômica, as cidades preexistentes, nas áreas de povoamento mais ou menos antigo, devem adaptar-se às demandas do mundo rural e das atividades agrícolas, no que se refere tanto ao consumo das famílias quanto ao consumo produtivo, isto é, o consumo exigido pelas atividades agrícolas ou agroindustriais. Quanto às cidades, aquelas cujas dimensões são maiores, utilizam parte dos terrenos vazios, dentro da aglomeração ou em suas proximidades, com atividades agrícolas freqüentemente modernas e grandemente destinadas ao consumo da respectiva população. As regiões metropolitanas, oficiais ou de fato, são o melhor exemplo desse fenômeno. Teríamos, desse modo, no primeiro caso, áreas agrícolas contendo cidades adaptadas às suas demandas $\mathrm{e}$, no segundo caso, áreas rurais adaptadas a demandas urbanas".

Para LEFEBVRE (2006, p.68-69), atualmente a relação cidade-campo se transforma, aspecto importante de uma mutação geral. Nos países industriais, a velha exploração do campo circundante pela cidade, centro de acumulação de capital, cede lugar a formas mais sutis de dominação e de exploração, tornando-se a cidade um centro de decisão e aparentemente de associação. Seja como for, a cidade em expansão ataca o campo, corrói-o, dissolve-o. A vida urbana penetra na vida camponesa despojando-a de elementos tradicionais. Temos a decadência do artesanato local, pequenos centros que definham em proveito dos centros urbanos maiores; as aldeias perdem a sua especificidade camponesa e alinham-se com as cidades.

O que não dizer dos modernos conglomerados de cidades, as regiões metropolitanas. Estas, segundo CASTELLS (2006, p.57), enquanto forma central de organização do espaço do capitalismo avançado, reduzem a importância do ambiente físico, anulam a distinção entre rural e urbano. 
É preciso reconhecer que, diante da complexidade de certos problemas, o direito costuma ter uma visão simplificadora e até certo ponto conservadora da realidade, como é o caso dos conceitos "rural" e "urbano", "campo" e "cidade".

E o que é cidade então? Eis um dos mais polêmicos conceitos sobre o qual se debruçam filósofos, sociólogos, antropólogos, geógrafos, historiadores, urbanistas, biólogos, desde a antigüidade até hoje, sem se chegar a um consenso. Nas palavras de BRANCO (1999, p.127), ela tem recebido inúmeras definições as quais refletem, na verdade, diferentes pontos de vista sobre a sua formação ou a sua função social. Alguns desses conceitos, segundo GOITIA (1996, p.08), mesmo sem serem contraditórios, muitas vezes não têm nada a ver com outros igualmente respeitáveis. Tais dissonâncias não decorrem de erro, mas sim do fato de existirem cidades que são constitutivamente diferentes. A polis grega é muito diferente da cidade medieval; uma vila cristã e uma medina muçulmana são distintas uma da outra.

ROLNIK (2004, p.12), diante de fenômenos tão diferentes como as antigas cidades muradas e as gigantescas metrópoles contemporâneas, questiona a possibilidade de se encontrar uma definição para cidade. Na busca de algum sinal que pudesse apontar uma característica essencial da cidade de qualquer tempo e lugar, a imagem criada por esta autora é a de um imã. Isto é, a cidade é como um campo magnético que atrai, reúne e concentra os homens.

No entender de MUNFORD (1982, p.9), não há definição que se aplique sozinha a todas as manifestações da cidade, nem descrição isolada que cubra todas as suas transformações, desde o núcleo social embrionário até as complexas formas da sua maturidade e a desintegração corporal da sua velhice. As origens da cidade são obscuras e são dificeis de prever suas perspectivas futuras.

Destarte, muitos conceitos de cidade soam datados, pois se referem a condições sociais, políticas e econômicas muito especificas, ocorridas num determinado local e lapso de tempo.

Aristóteles em sua Política, apud GOITIA (1996), afirmou que uma cidade consiste num certo número de cidadãos, sendo cidadão de um cidade aquele 
que possui a faculdade de intervir nas funções deliberativa e judicial da mesma, e cidade em geral ao número total de cidadãos, suficiente para as necessidades da vida (p.08). Este conceito corresponde à típica cidade-estado grega da época em que Aristóteles vivia.

Afonso X o Sábio, rei ibérico do século XIII, em seu célebre código "Siete Partidas", apud GOITIA (1996, p.08), definia cidade como todo o lugar encerrado por muralhas, com os arrabaldes e edificios que aquelas defendem. Obviamente tem-se aqui um conceito de cidade medieval não mais aplicável na sua generalidade aos dias atuais.

Cantillon, autor do século XVIII, entendia como origem da cidade a vontade do príncipe. Se este fixasse a sua residência num local e se outros senhores ali acorressem para conviverem em sociedade, este local converter-se-ia numa cidade (apud GOITIA, 1986, p.09). Eis aqui a cidade barroca, governada por soberanos absolutos.

Ainda no século XVIII, mas já dentro do espírito iluminista, a Encyclopédie, segundo BRESCIANI (2002, p.20), em seu verbete especifico, de maneira singela, conceitua "cidade" com um conjunto de várias casas dispostas em ruas e cercadas por uma cinta comum, composta em geral por muros e fossos. Mais um conceito restrito a uma época.

Para Ortega y Gasset, apud GOITIA (1986, p.09), a cidade é uma tentativa de secessão feita pelo homem para viver fora e frente ao cosmos, do qual aproveita porções escolhidas e delimitadas. Este conceito baseia-se numa diferenciação radical entre cidade e natureza, considerando aquela como uma criação abstrata e artificial do homem. Esta é apenas uma parte da verdade, ou pelo menos uma verdade aplicável a determinado tipo de cidade, já que para Ortega a cidade por excelência é a cidade clássica e mediterrânica, onde o elemento fundamental é a praça. 
Sob o ponto de vista de categoria sociológica, segundo OLIVEN (1984, p.14), existem autores que entendem a cidade como variável dependente, os quais estão geralmente interessados em fatores históricos e portanto estudam-na como resultado de várias causas econômicas, políticas e sociais. Para eles existiriam cidades de diversos tipos, desempenhando funções distintas, dependendo das diferentes circunstâncias e forças históricas. Entre estes autores podemos identificar Max Weber e Karl Marx.

De acordo com OLIVEN (1984, p.15), Weber formulou um conceito construído a partir de uma série de circunstâncias ou condições necessárias para a existência e desenvolvimento de cidades. Em seu entendimento, apesar dos homens terem construído moradias em assentamentos relativamente fechados em diferentes períodos e civilizações, somente no Ocidente teria existido uma comunidade urbana no sentido pleno da palavra e como fenômeno extenso. Para tanto se fazia necessária a existência de estabelecimentos de pronunciado caráter industrial-mercantil a que correspondessem as seguintes características: 1) a fortaleza, 2) o mercado, 3) tribunal próprio e direito ao menos parcialmente próprio, 4) caráter de associação, e, unido a isso, 5) ao menos uma autonomia e autocefalia parcial, portanto, administração a cargo de autoridade em cuja escolha os burgueses participassem de alguma forma.

Portanto, de acordo com Weber, apud OLIVEN (1984, p.15), a cidade implica na existência de uma comunidade com um alto grau de autonomia, tanto sob o ponto de vista objetivo (mercado, fortificação, exército, tribunal e direito ao menos parcialmente próprio), quanto sob o ponto de vista subjetivo, como um conjunto de lealdades. A cidade é vista como pré-condição do capitalismo. Porém, posteriormente, o desenvolvimento do capitalismo acabaria por intensificar o crescimento das cidades.

Marx, por seu turno, ainda conforme OLIVEN (1984, p.15-16), entende que a economia urbana requer um processo prévio de divisão social do trabalho. No caso das cidades da Europa Ocidental da Idade Moderna isto significou o desenvolvimento de um novo padrão de exploração, não mais através de um sistema de estamentos feudais, mas por meio de classes sociais. Para tanto é necessária de um 
lado a existência de uma força de trabalho "livre", não sujeita aos laços de servidão feudal, mas também desprovida dos meios de produção, portanto disponível para vender sua capacidade de trabalho no mercado. De outro lado, uma classe burguesa que também se libertou da dominação dos senhores feudais, mas cuja posição social está mais ligada à detenção de capital do que à posse de terras ou títulos de nobreza e que está disposta a adquirir e utilizar esta capacidade de trabalho. E é na cidade que estes dois atores sociais se encontram e interagem.

O desenvolvimento de um modo de produção capitalista, de acordo com Marx, apud OLIVEN (1986, p.16), ocorreu por meio das transformações que tiveram lugar em cidades nas quais as manufaturas foram destruídas pelas fábricas às quais os servos acorreram depois de fugirem ou serem expulsos do campo. E é nesse sentido que a cidade é um mercado. Mercado não apenas de bens e de dinheiro (dos capitais), como também de trabalho (da mão-de-obra).

Ainda dentro da visão da cidade como categoria sociológica, existem autores que tentaram estudar a cidade como uma variável independente, isto é, como uma potência social capaz de gerar com sua influência os mais variados efeitos na vida social, entre os quais o de maior alcance seria a cultura urbana (OLIVEN, 1984, p.19-20).

Entre eles temos Robert Ezra Park, que definia a sociedade como um “organismo social". Cidade para ele era um estado de espírito, um corpo de costumes e tradições e de sentimentos e atitudes organizados, inerentes a esses costumes e transmitidos por essa tradição. Ele considerava como objeto de estudo tudo que ocorresse num contexto urbano, já que encarava a cidade como um "laboratório social" (apud OLIVEN, 1984, p.20).

Um de seus discípulos, Louis Wirth, por sua vez, definiu a cidade como um núcleo relativamente grande, denso e permanente de indivíduos, socialmente heterogêneo. Isto é, os elementos fundamentais para definir o meio urbano são tamanho, densidade, permanência e heterogeneidade. Para Wirth quanto mais densamente habitada, quanto mais heterogênea for a comunidade, tanto mais acentuadas serão as características urbanas (avud OLIVEN. 1984. n 21) 
Já o antropólogo Robert Rewdfield comparando diferentes pontos de seu continuum folk-urbano (a vila tribal com a vila camponesa, esta com a pequena cidade e esta última com a cidade) defendia que quanto mais se passava do extremo folk (aldeia tribal) para o urbano, menor seria o isolamento, maior a heterogeneidade, mais complexa a divisão de trabalho, mais desenvolvida a economia monetária, majs seculares os especialistas profissionais, menos bem organizados e menos eficazes no controle social as instituições de parentesco e compadrio. Correspondentemente, haveria maior dependência de instituições de controle de ação impessoal, menor religiosidade, menor tendência a encarar as doenças como resultantes da quebra de uma regra moral ou meramente de costumes e maior liberdade de ação e escolha individual (apud OLIVEN, 1984, p.24-25).

Oferecendo uma visão geográfica da cidade, Friedrich Ratzel, um dos fundadores da geografia humana, conceitua cidade como uma reunião durável de homens e habitações humanas que cobre uma grande superficie e encontra-se no cruzamento de grandes vias comerciais (apud ROLNIK, 1988, p.21-22). Para outro geógrafo, Pierre George, as cidades são formas de acumulação humana e de atividades concentradas, próprias a cada sistema econômico e social, reconhecidos a partir de fatos de massa e arquitetônicos (Idem, p.68).

SCARLATO (2001, p.400), ao analisar a população e a urbanização brasileira, levanta a seguinte questão: se quisermos abordar o conceito pelo viés estatístico, defrontamo-nos com um outro problema: quantos habitantes serão necessários para se considerar um aglomerado como cidade? Neste caso, muitas vezes os países acabam adotando, como critério definidor, números diferentes um do outro. Como informa CASTELLS (2006, p.41), o recenseamento dos Estados Unidos toma o limiar de 2.500 habitantes como critério de comunidade urbana, mas acrescenta também os aglomerados fortemente unidos a um centro metropolitano regional. Em contraposição, a Conferência Européia de Estatística em Praga estabelece como critério o fato de ter mais de 10.000 habitantes. Ainda mais contrastantes são os exemplos trazidos à baila por GIST e FAVA (1968, p.85): a 
Dinamarca reconhece como urbanas localidades que tenham no mínimo 250 habitantes, enquanto na Coréia exige-se um mínimo de 40.000 habitantes.

Mais consistente, segundo o mesmo autor, é o critério das atividades desenvolvidas pelos habitantes. Conforme o critério de Ratzel e incorporando este das atividades, a cidade pode ser definida como todo aglomerado permanente cujas atividades não se caracterizem como agrícolas. A grande concentração das atividades terciárias públicas e privadas do aglomerado e a forma contínua dos espaços edificados onde se dá a proximidade das habitações da população que vive dessas atividades são atributos que permitem melhor caracterizar o termo cidade. De forma muito genérica, pode-se dizer que, nestas condições, a aglomeração é importante por ser organizada para o trabalho coletivo em atividades não-agrícolas (SCARLATO, 2001, p.400-401).

Sob o ponto de vista ecológico Scarlato e Pontin, apud MARQUES (2005, p.94), entendem a cidade como um grande ecossistema, heterotrófico, ou seja, um ecossistema incompleto, que depende de áreas externas a ele para obtenção de energia, alimentos, água e outros produtos.

Nessa mesma linha, PHILIPPI JR e MALHEIROS (2005, p.05) enumeram as principais características do ambiente urbano: alta densidade demográfica; relação desproporcional entre ambiente construído e ambiente natural; importação de energia para manter o sistema em funcionamento; elevado volume de resíduos; alteração significativa da diversidade biológica nativa, como a retirada das florestas e a importação de espécies vegetais e animais; o desbalanceamento dos principais ciclos biogeoquímicos, como o ciclo da água, do carbono, do nitrogênio e do fósforo; a impermeabilização do solo e a alteração dos cursos d'água.

No âmbito urbanístico, como expressa Virgílio Testa, apud SILVA (2006, p.26), um centro populacional assume característica de cidade quando possui dois elementos essenciais: (a) as unidades edilícias, isto é, o conjunto de edificações em que os membros da coletividade moram ou desenvolvem suas atividade produtivas, comerciais, industriais ou intelectuais; (b) os equipamentos públicos, ou seja, os bens 
públicos e sociais criados para servir às unidades edilicias e destinados à satisfação das necessidades de que os habitantes não podem prover-se diretamente e por sua própria conta, tais como ruas, praças, parques, canalizações subterrâneas, iluminação pública, escolas, hospitais, mercados, etc.

VIZZOTTO (2006, p.174) enxerga a cidade como o espaço para a aquisição da cidadania. Além da função urbanística, sociocultural e política, a cidade funciona como elo espacial entre os diversos espaços urbanos, conectando lugares diferentes e dando-lhes identidade própria. O espaço enquanto coletivo é polivalente, local de intercâmbio, de participação, de tolerância, de transgressão. Mas será, justamente por essas caracteristicas, espaço do público e de domínio público. A cidade, além disso, concretiza o tempo e a memória e plasma a identidade de cada comunidade. Este conceito torna-se mais importante na medida em que procura enxergar os aspectos positivos da cidade, que sem dúvida existem, ao contrário do que pretendem certas concepções que apenas enxergam o espaço urbano como caos ambiental, mercadoria, cenário de opressão, de desigualdades e violência.

Lúcio Costa (apud FREITAG, 2002, p.207) define a cidade como sendo a expressão palpável da necessidade humana de contato, comunicação, organização e troca, numa determinada circunstância físico-social e num contexto histórico. Neste conceito destaca-se a importância atemporal das cidades para o ser humano, ao mesmo tempo que a sua mutabilidade no tempo e no espaço.

Segundo HIERNAUX (2006, p.198-199), a maior parte dos autores que estudaram a cidade entende que a mesma se caracteriza pela concentração de certa quantidade de população, por certa densidade física, pela presença de atividades não diretamente ligadas à produção do campo e por um modo de vida distinto do que prevalece nas zonas que se qualificam como rurais.

Portanto o mesmo HIERNAUX (2006, p.199-200) propõe uma definição alternativa de urbano que leva em conta três categorias fundamentais: o labirintico, o fugaz e o fortuito. Estas três são figuras metafóricas, pois representam mais um estado absoluto, inatingível em forma total, que uma realidade concreta. A cidade é 
antes de tudo uma forma sócio-espacial cuja interpretação, tanto pelo habitante como pelo analista, requer um andar labiríntico: a complexidade se aninha na cidade e a transforma em um tecido de caminhos mentais e físicos que obriga as idas e vindas, retrocessos, avanços e raras vezes, a chegada a uma saida evidente. $\mathrm{O}$ fugaz decorre de uma característica essencial do urbano que é a ausência de duração, a volatilidade das coisas, das pessoas, das ações e dos pensamentos. Finalmente o fortuito remete ao caráter caótico, espontâneo de muitos eventos urbanos.

Explica também HIERNAUX (2006, p.203-204) que uma cidade tem que ter as três características mencionadas. Mas, além disso, elas têm que possuir essas características de forma simultânea e articulada. Assim, não é possivel que um labirinto sem o caráter fortuito e sem a fugacidade constitua uma cidade. Tampouco é possível que os eventos de caráter fortuito e/ou fugaz possam constituir-se numa representação da cidade sem o labirintico que é seu substrato, não somente físico, mas também mental.

\subsubsection{Conceitos de urbano e rural no ordenamento jurídico brasileiro}

Do ponto de vista juridico, urbano e rural são tipicamente conceitos indeterminados. Segundo Garcia de Enterria, apud CONCEIÇÃO (1999, p.51), os conceitos usados pela lei são determinados e indeterminados, caracterizando-se os primeiros pela maneira precisa e inequívoca com que se referem à realidade. Já os segundos fazem referências a realidades cujos contornos não podem ser delimitados com precisão. Ratifica o autor que a lei, ainda que se dirija a um aspecto específico da realidade, não define exatamente os limites alcançados pelo conceito indeterminado.

$\mathrm{Na}$ aplicação dos termos indeterminados é preciso fazer um exame se, no caso concreto, a solução adotada pela administração satisfaz a finalidade legal. Muitas vezes a norma confere mais de uma solução possível para o aplicador, sendo que somente diante das circunstâncias fáticas é que se pode verificar qual a solução 
ótima, a melhor solução possível, e o Poder Judiciário também tem competência para exercer o seu controle (OHLWEILER, 2000, p.35).

No ordenamento jurídico brasileiro existem vários conceitos de "rural" e, por conseguinte, seu oposto que é "urbano", dispostos em vários textos legais, de diferentes ramos do direito, como analisamos a seguir.

O critério mais comum para definir zona urbana, utilizado no Brasil pelo IBGE, é o político-administrativo e assim entende-se como urbana toda sede de Município (cidade) e de Distrito (vila). Desse modo, são consideradas áreas urbanizadas toda área de vila ou de cidade, legalmente definida pelo Município como urbana e caracterizada por construções, arruamentos e intensa ocupação humana; as áreas afetadas por transformações decorrentes do desenvolvimento urbano e aquelas reservadas à expansão urbana (IBGE, apud MARQUES, 2002, p.97).

Neste sentido, a cidade no Brasil caracteriza-se por ser um núcleo urbano, sede do governo municipal, qualquer que seja a sua população (SILVA, 2006, p.26).

Este critério é objeto de muitas críticas, eis que não é feita qualquer referência às funções peculiares dos diferentes aglomerados que constituem um fator fundamental na diferenciação entre a zona rural e a zona urbana (Grabois, apud MARQUES, 2002, p.97). Nesta classificação, a zona rural corresponde ao espaço que não é urbano, sendo portanto definida a partir de suas carências e não de suas próprias características. Além disso, o rural, assim como o urbano, terminaria sendo definido pelo arbítrio dos poderes municipais, muitas vezes influenciados por seus interesses de arrecadação tributária (MARQUES, 2002, p.97).

Outrossim, tal critério levaria a classificar como urbanas sedes de municípios muito pequenas, às vezes com população inferior a dois mil habitantes, o que seria ainda pior no caso de algumas sedes distritais. Tal distorção terminaria por denominar como "cidade" o que na verdade seria apenas uma aldeia, povoado ou vila, resultando numa possivel superestimação do grau de urbanização do Brasil (Veiga apud MARQUES, 2002, p.97). 
Apesar de tais críticas, bastante pertinentes, o conceito do IBGE corresponde àquele legal previsto na Lei 6.766 de 19/12/1979, Lei de Parcelamento do Solo Urbano. $\mathrm{O}$ art. $3^{\circ}$ deste diploma legal determina que somente será admitido o parcelamento do solo para fins urbanos em zonas urbanas, de expansão urbana ou de urbanização específica, assim definidas pelo plano diretor ou aprovadas por lei municipal. Portanto, cumpre, em principio, ao Municipio definir a zona urbana por lei municipal específica ou em seu plano diretor (igualmente aprovado por lei municipal). Por exclusão, o que restar do território do Município, será zona rural.

Outro conceito de zona rural pode ser encontrado também no Estatuto da Terra (Lei 4.504 de 30/11/1964. Em seu art. $4^{\circ}$, inc. I, temos o conceito de imóvel rural, como o prédio rústico, qualquer que seja a sua localização, que se destine à exploração extrativa agrícola, pecuária ou agroindustrial. O Decreto 55.891 de $31 / 03 / 1965$ que o regulamentou, em seu art. $5^{\circ}$, especifica a expressão "qualquer que seja a sua localização", acrescentando "em perímetros urbanos, suburbanos ou rurais dos municipios.". Vislumbramos nesta disposição legal a intenção do legislador de impedir a descaracterização de imóveis destinados à produção agropecuária e agroindustrial. Nada mais natural, pois a produção agropecuária não deve ser desmantelada por uma urbanização desenfreada eventualmente pretendida pelos Municípios.

Cabe aqui um parêntesis, eis que desde jả surge um conflito entre leis. Podemos imaginar áreas que sejam consideradas urbanas com fundamento na Lei do Parcelamento do Solo e, simultaneamente, rurais com fulcro no Estatuto da Terra. Como solucioná-lo?

Uma solução adequada parece ser aquela oferecida por Toshio Mukai. Um imóvel rural que tenha perdido suas características de exploração agricola, extrativa vegetal, pecuária ou agroindustrial, deverá obedecer a duas condições para poder ser loteado para fins de sitio de recreio ou qualquer outro fim urbano: $1^{\circ}$ ) prévia audiência do Instituto Nacional de Colonização e Reforma Agrária (INCRA), do Órgão Metropolitano, se existente e aprovação da prefeitura municipal, ou do Distrito Federal quando for o caso, segundo as exigências da legislação pertinente 
(art. 53, da Lei 6.766/79); $2^{\circ}$ ) ser incluído, por lei municipal, ao menos em zona de expansão urbana. Sem o preenchimento de tais condições, o empreendimento será ilegal e irregular (MUKAI, 2004, p.128 e 129).

Outro conceito de zona urbana e, por conseqüência, de zona rural, encontra-se no art. $32, \S 1^{\circ}$, do Código Tributário Nacional. Por este diploma legal zona urbana é aquela definida em lei municipal, observado o requisito mínimo da existência de melhoramentos indicados em pelo menos dois dos incisos seguintes, construídos ou mantidos pelo poder público: I- meio-fio ou calçamento com canalização de águas pluviais; II- abastecimento de água; III- sistema de esgotos sanitários; IV- rede de iluminação pública, com ou sem posteamento, para distribuição domiciliar; V- escola primária ou posto de saúde a uma distância máxima de três quilômetros do imóvel considerado. Já a zona rural é aquela área do município que não preenche tais requisitos.

O conceito de zona urbana determinado pela lei urbanística municipal de que trata a Lei de Parcelamento do Solo (art. $3^{\circ}$ da Lei 6.766/79) é o mesmo de que trata o art. $32, \S 1^{\circ}$, do Código Tributário Nacional? Não necessariamente. Porém, segundo MEIRELLES (1996) apud MUKAI (2004, p.126), é de toda conveniência que a lei urbanística municipal faça coincidir as suas exigências com as do Código Tributário Nacional, ou, pelo menos, as imponha com maior rigor, a fím de que possa arrecadar na área o imposto predial e territorial urbano.

Temos aqui um conceito de zona urbana voltado exclusivamente à arrecadação tributária e mais uma definição de zona rural por mera exclusão. E com um agravante. Sendo o Código Tributário Nacional considerado uma lei complementar, em razão do disposto no art. 146 da Constituição Federal de 1988, seu art. $32, \S 1^{\circ}$, deve, em princípio, prevalecer sobre os mencionados art. $3^{\circ}$ da Lei $6.799 / 79$ e art. $4^{\circ}$, inc. I, do Estatuto da Terra, como também sobre aquele dispositivo que nos interessa mais especialmente, qual seja o art. 49 e $\S$ único, da Lei do SNUC, eis que são leis ordinárias, isto é, diplomas legais hierarquicamente inferiores. 
Em resumo, no que tange a zonas urbanas e rurais, prevaleceria obrigatoriamente o conceito do Código Tributário Nacional. Ou seja, todas as complexas questões envolvendo o meio rural e o meio urbano, o campo e a cidade, estariam resumidas unicamente ao aspecto tributário, por sua vez subordinado ao poder quase hegemônico dos Municípios.

\subsubsection{Relação entre lei complementar e lei ordinária}

Não seria esse o entendimento doutrinário mais moderno. Em verdade não existiria a superioridade hierárquica da lei complementar sobre a lei ordinária. Segundo CAMPILONGO (2002, p.484 e 485), a doutrina majoritária reconhece que a lei complementar tem assegurado, pela Constituição Federal, um campo material determinado, que não pode ser invadido por lei ordinária. Ou seja, uma reserva legal qualificada (competência ratione materiae) e não de superioridade hierárquica. Se não há campo material comum, não há como se discutir hierarquia. Do mesmo modo que a lei ordinária, por respeito à Constituição, não pode invadir o campo da lei complementar, a esta última é vedada a invasão do campo de atuação da lei ordinária, com fundamento na mesma Lei Maior.

CAMPILONGO (2002, p.484) menciona ainda uma posição intermediária, sustentada por Souto Maior que entende poder haver subordinação da lei ordinária à lei complementar apenas quando esta última fundamenta a validade daquela. Ainda assim, quando a lei complementar disciplinar matéria de competência da legislação ordinária, extrapolando seu próprio campo material, ela será substancialmente ordinária e poderá ser revogada por outra lei ordinária.

Em síntese, o mesmo CAMPILONGO (2002, p.484) observa que no caso de uma lei complementar e uma lei ordinária disciplinarem matéria idêntica, duas situações poderão ser observadas: a) a matéria é reservada a lei complementar, que deve prevalecer, pois a lei ordinária, de forma inconstitucional, invadiu seara alheia; 
b) a matéria não é reservada a lei complementar, pelo que deve prevalecer a lei ordinária que seja posterior à lei complementar, já que esta extrapolou de seu próprio campo material, pois não existe hierarquia entre ambas, as quais retiram igualmente sua validade diretamente da Constituição.

Sendo assim, no que tange à determinação dos conceitos de zona urbana e zona rural, o Código Tributário Nacional não pode prevalecer sobre dispositivos análogos oriundos de leis ordinárias, como as já mencionadas acima. Tal matéria não é de competência de lei complementar, eis que não elencada expressamente entre aquelas do art. 146 da Constituição Federal. É matéria de lei ordinária e como tal deve ser tratada.

Em idêntico sentido temos SILVA, J. A. (2007a, p.249) que afirma existirem normas e princípios que autorizam a conclusão de que a lei complementar somente pode cuidar das matérias a ela reservadas pela Constituição. Assim, o art. 61 da Carta Magna reconhece separadamente a existência de ambas, a propósito do poder de iniciativa, e só se vai saber se o caso é de iniciativa de lei complementar se a matéria de que se busca tratar exige tal tipo de lei, o que só se descobre pela indicação expressa da Constituição. Fora disso a matéria é de lei ordinária, pouco importando com que quorum em cada caso concreto ela foi aprovada. Uma lei não deixa de ser ordinária quando não se exige outra forma, mesmo que tenha sido aprovada pela unanimidade das duas casas do Congresso Nacional.

Voltando ao tema que nos interessa diretamente, isto é, a Lei do SNUC, é de se concluir que o art. 49, e seu $\S$ único, que determina que as áreas das unidades de conservação do grupo de proteção integral devem ser consideradas como zona rural para os efeitos legais e que as zonas de amortecimento, quando definidas formalmente, não podem ser transformadas em zona urbana, é um dispositivo legal perfeitamente constitucional. Igualmente, o significado de "zona rural" e "zona urbana" não precisa se subordinar necessariamente àqueles conceitos contidos no Código Tributário Nacional, haja vista que a Lei do SNUC lhe é posterior. Ao tratar destas definições, que não consistem em matéria tributária, o Código Tributário Nacional deve ser tratado como lei ordinária. 


\subsubsection{Significado de zona rural e zona urbana para a Lei do SNUC}

Uma vez que "zona rural" e "zona urbana" são conceitos indeterminados, que a área de uma unidade de conservação de proteção integral deve ser considerada "zona rural para os efeitos legais" e que a respectiva zona de amortecimento, "uma vez definida formalmente, não pode ser transformada em zona urbana", qual deve ser o melhor significado para tais expressões, considerando os objetivos e diretrizes que devem nortear o SNUC?

Não se aplica ao caso em tela o conceito de "imóvel rural" do Estatuto da Terra eis que este pressupõe o seu uso em exploração extrativa agrícola, pecuária ou agroindustrial. Tais atividades consistem em uso direto do bem, pois envolvem uso comercial dos seus recursos naturais (art. $2^{\circ}$, inc. X, da lei do SNUC). Ora, nas unidades de conservação de proteção integral somente é permitido o uso indireto, isto é, aquele que não envolve consumo, coleta, dano ou destruição dos recursos naturais (art. $7^{\circ}$, inc. I, $\S 1^{\circ}$ c.c. art. $2^{\circ}$, inc. IX, da Lei do SNUC).

O objetivo básico das unidades de conservação de proteção integral é a preservação da natureza, é a manutenção dos ecossistemas livres de alterações causadas por interferência humana, admitido apenas o uso indireto dos seus atributos naturais (art. $7^{\circ}$, inc. $1^{\circ}$ c.c. art. $2^{\circ}$, inc VI, da Lei do SNUC).

Portanto, quando o legislador afirma que tais áreas devem ser consideradas zona rural para os efeitos legais, ele busca evitar que as mesmas sofram processo de urbanização. Uma área adquire qualificação urbana quando ordenada para cumprir destino urbanístico, especialmente a edificabilidade e a vialidade (de viário), que não são, por natureza, qualidades do solo (SILVA, 2006, p.82). É óbvio que tal processo implica necessariamente em alterações sérias dos ecossistemas naturais, incompativeis com a pretendida proteção ambiental. 
Idêntico raciocínio cabe para as respectivas zonas de amortecimento. Neste caso o legislador é até mais claro ao proibir que as mesmas sejam transformadas em zona urbana.

$\mathrm{O}$ art. 49 da Lei do SNUC cria uma limitação expressa à competência municipal prevista no art. $3^{\circ}$ da Lei de Parcelamento do Solo Urbano e também àquela constante do art. $32, \S 1^{\circ}$ do Código Tributário Nacional, com a finalidade de proteger o meio ambiente.

Destarte, quando se tratar de área integrante de unidade de conservação de proteção integral e sua respectiva zona de amortecimento, o Município não poderá nela definir zona urbana, de expansão urbana ou de urbanização específica, seja por seu plano diretor ou por lei municipal. Assim não será admitido o parcelamento do solo para fins urbanos nessas áreas. Neste caso, a Lei do SNUC está apenas especificando melhor a própria Lei de Parcelamento do Solo Urbano que proíbe o parcelamento do solo em áreas de preservação ecológica (inc. $\mathrm{V}$ do $\S$ único do art. $3^{\circ}$ ).

No que tange ao Código Tributário Nacional, o Município não poderá declarar área de unidade de conservação de proteção integral e respectiva zona de amortecimento como urbana para fins de arrecadação de imposto predial e territorial urbano, ainda que preenchidos os requisitos do $\S 1^{\circ}$ do seu art. 32. Seria estimular a urbanização da área, descaracterizar espaço territorial especialmente protegido, cuja proteção é de interesse de todo o poder público (art. $225, \S 1^{\circ}$, inc. III da Constituição Federal). Em suma, estaria legislando sobre assunto que extrapola o seu interesse local, em desacordo com o disposto no art. 30, inc. I da Carta Maior.

Nesse mesmo sentido, DERANI (2001, p.611) reconhece que o sistema econômico é dissipativo e não se autoperpetua. O mercado tende a colonizar todos os campos da sociedade, daí a necessidade de o direito como imposição estatal definir limites para essa expansão. Existem duas formas convencionais de apropriação social do espaço: o espaço urbano e o espaço agrícola. Estes devem se acomodar a uma terceira modaliḍade que é o espaço especialmente protegido. Onde existem unidades de conservação de proteção integral não existe urbanização ou agricultura. 
Não se alegue que a Lei do SNUC é inconstitucional por ferir a autonomia municipal em matéria urbanística. É competência constitucional da União estabelecer normas gerais, válidas para todo o território nacional, sobre direito urbanístico e proteção do meio ambiente (art. 24 , incs. I e VI e $\S 1^{\circ}$ da Constituição Federal).

É preciso ressaltar que o art. 49 da Lei do SNUC em momento algum determina que a criação de uma unidade de conservação do grupo de proteção integral e implantação de sua zona de amortecimento somente possa ocorrer em área rural. Pelo contrário, tal mandamento visa apenas impedir que o espaço por ela ocupado seja apropriado socialmente pela urbanização. Aliás, a Lei do SNUC, como um todo, não possui qualquer dispositivo que exclua a priori a implantação de unidades de conservação no meio urbano já consolidado, desde que a categoria escolhida seja adequada.

A título de exemplo, podemos trazer as Reservas Particulares do Patrimônio Natural Municipais (RPPNM) de Curitiba, criadas com fundamento no Decreto Municipal 606, de 04/06/2007, as quais apresentam o diferencial de estarem localizadas em áreas urbanas, terem o entorno bastante alterado e sofrerem fortes pressões antrópicas (RIBEIRO, 2008, p.03). Cumpre salientar que as Reservas Particulares do Patrimônio Natural tornaram-se unidades de conservação de proteção integral, onde somente são possíveis atividades de uso indireto, a partir do veto presidencial ao inc. III do $\S 2^{\circ}$ do art. 21 da Lei do SNUC (RODRIGUES, 2005a, p.340-341). Destarte, a RPPNM é uma categoria unidade de conservação de proteção integral do meio urbano. E de grande utilidade, pois, como afirma RIBEIRO (2008, p.05), incentivar a transformação de áreas verdes particulares, relevantes para a conservação da biodiversidade, em RPPNM, é uma forma hábil de garantir a perpetuidade dessas áreas, desonerar os cofres públicos da sua manutenção e integrar a comunidade à proteção do meio ambiente. 


\subsection{MEIO AMBIENTE ARTIFICIAL}

4.5.1. Visão ecossistêmica e social da cidade

É voz corrente que meio ambiente diz respeito apenas à natureza, preferencialmente intocada e que os aglomerados urbanos seriam a sua négação.

Este tipo de afirmação não tem cunho científico nem legal. De longa data o ordenamento jurídico brasileiro tem conceituado meio ambiente de forma bastante abrangente. Pela Lei 6.938 de 31 de agosto de 1981 (Lei da Política Nacional de Meio Ambiente), meio ambiente é o conjunto de condições, leis, influências e interações de ordem física, química e biológica, que permite, abriga e rege a vida em todas as formas (art. $3^{\circ}$, inc. I). Por permitir, abrigar e reger a vida em todas as formas, é que o meio ambiente inclui áreas naturais intocadas ou degradadas, mares e terras, áreas rurais e urbanas, pois em todos esses espaços encontramos formas de vida (RODRIGUES, 1998, p.199).

Ecologia não se confunde com meio ambiente. Enquanto ecologia é a "ciência da morada", que estuda a relação entre os organismos e seu habitat, meio ambiente vem a ser a própria morada dos seres vivos (KLOETZEL, 2002, p.14). No limite, meio ambiente abrange toda a biosfera, isto é, a esfera da vida, o conjunto de lugares onde é possível, pelo menos a algumas espécies, viver de modo permanente, alimentar-se, reproduzir-se (FRIEDEL, 1979, p.09).

MILARÉ (2007, p.110-111) observa que, no campo jurídico, podemos distinguir duas perspectivas principais para o meio ambiente: uma estrita e uma ampla. Numa visão estrita, o meio ambiente nada mais é que a expressão do patrimônio natural e as relações com e entre os seres vivos. Tal noção, é evidente, despreza tudo aquilo que não diga respeito aos recursos naturais. Numa concepção ampla, que vai 
além dos limites estreitos da ecologia tradicional, o meio ambiente abrange toda a natureza original (natural) e artificial, assim como os bens culturais correlatos.

O jurista português Figueiredo Dias (apud CRUZ, 2002, p.27) também entende que quanto ao conceito de ambiente pode-se optar por uma concepção estrita, centrada apenas nos componentes ambientais naturais, ou por uma análise ampla, que venha a abarcar tanto os elementos naturais, como os econômicos, sociais e culturais, significando tudo aquilo que nos rodeia e que influencia, direta ou indiretamente, a nossa qualidade de vida e a dos seres vivos que constituem a biosfera. Ressalta CRUZ (Idem) que o mesmo autor deixa clara a sua opção por um conceito mais estrito, relativo apenas aos elementos naturais, apesar da vigente Constituição Portuguesa prescrever em seu art. 66 que "todos têm direito a um ambiente de vida sadio e ecologicamente equilibrado e o dever de o defender".

Tendo em vista o dispositivo do art. 66 da Constituição Portuguesa e o do art. 225 da Constituição Brasileira, verifica com acerto CRUZ (2002, p.27) que o meio ambiente é pressuposto para o exercício do direito à vida saudável. Portanto, a posição do jurista português conflita com o direito positivo, uma vez que para o desenvolvimento pleno da vida saudável tanto os aspectos naturais, como os artificiais, culturais, são imprescindiveis. Esse conceito de saúde é entendido quer sob o ponto de vista físico, quer sob o aspecto moral ou psicológico.

FREITAS (2008, p.201) destaca que o constituinte brasileiro de 1988, além do meio ambiente natural tutelado no art. 225 , caput e $\S 1^{\circ}$, concebeu outras três formas: o meio ambiente cultural, formado pelo patrimônio histórico, artístico, arqueológico, turístico e científico (art. 216); o meio ambiente do trabalho, caracterizado pelas condições de salubridade e segurança que envolvem as atividades laborais (art. 200, inc. VIII) e o meio ambiente artificial, integrado pelo espaço urbano construído (arts. 182 e 255 ).

Pode-se questionar o porquê da expressão meio ambiente e não apenas ambiente, como se costuma utilizar mais comumente em Portugal. SILVA J. A. (2007b, p.20-21) leciona que o ambiente integra-se, realmente, de um conjunto de 
elementos naturais e culturais, cuja interação constitui e condiciona o meio em que se vive. Daí por que a expressão "meio ambiente" se manifesta mais rica no sentido (como conexão de valores) do que a simples palavra "ambiente". Esta exprime o conjunto de elementos; aquela expressa o resultado da interação desses elementos. $O$ conceito de meio ambiente há de ser, pois, globalizante, abrangente de toda natureza original e artificial, bem como dos bens culturais correlatos, compreendendo, portanto, o solo, a água, o ar, a flora, as belezas naturais, o patrimônio histórico, artístico, turístico, paisagístico e arqueológico.

Destarte, SILVA J. A. (2007b, p.20) conceitua meio ambiente como a interação do conjunto de elementos naturais, artificiais e culturais que propiciem o desenvolvimento equilibrado da vida em todas as suas formas. A integração busca assumir uma concepção unitária de ambiente, compreensiva dos recursos naturais e culturais. Este conceito, conforme o mesmo autor (Idem, p.21), demonstra a existência de três aspectos do meio ambiente: meio ambiente artificial, meio ambiente natural e meio ambiente cultural. Neste último incluído o meio ambiente do trabalho (Idem, p.23).

CUSTÓDIO (2006, p.368) corrobora e aprimora tal entendimento, ao considerar meio ambiente como o conjunto tanto de circunstâncias e de relações recíprocas reguladas pelas leis naturais de ordem física, química e biológica como de fatores sócio-econômicos disciplinados pelas leis humanas do direito positivo, que de forma vinculada e interdependente, assegura condições favoráveis de existência, desde a concepção, a germinação ou qualquer outra circunstância originária, ao nascimento, ao desenvolvimento, à preservação e à continuidade da vida, em seus diversos ciclos normais evolutivos, da pessoa humana e dos demais seres vivos (animais, vegetais e microorganismos em geral).

A existência dessa multiplicidade e amplitude de aspectos do meio ambiente é apoiada ainda por RODRIGUES (2008, p.35-38), MANCUSO (2002, p.35), FIGUEIREDO (2008, p.39), FREITAS (2000, p.17), RICHTER (1999, p.26), MAZZILLI (1997, p.43), PINTO (1997, p.11-12), AGUIAR (1996, p.207-208), entre outros importantes juristas. 
Dentro das modalidades meio ambiente existentes, a que mais diz respeito ao nosso trabalho é a do meio ambiente artificial, que é aquele constituído pelo espaço urbano construído, consubstanciado no conjunto de edificações (espaço urbảno fechado) e dos equipamentos públicos (ruas, praças, áreas verdes, espaços livres em geral: espaço urbano aberto), conforme definição oferecida por SILVA J. A. (2007b, p.21).

Oportunas são as considerações a respeito de SANTOS e MOTTA (2001, p.90). Segundo estes autores, as cidades, enquanto meio transformado de maior complexidade, são caracterizadas principalmente pelas artificialidades e objetos técnicos em seu interior, os quais se combinam aos elementos da natureza reconstruídos ou preservados pela sociedade. Enquanto as artificialidades formam o meio ambiente da cidade e se constituem em seus recursos ambientais, a natureza reconstruída ou preservada é o meio ambiente na cidade e se constitui em seus recursos naturais.

Conforme os citados autores, o meio ambiente nas cidades, isto é, o verde urbano presente na arborização, nos parques, jardins e zonas especiais como áreas de risco e unidades de conservação, faz-se necessário tanto por influir no bem-estar dos atores sociais como para o adequado funcionamento do meio ambiente da cidade. Já o meio ambiente da cidade, com seu tom marrom ou cinza, viabiliza a vida urbana ao mesmo tempo em que causa a degradação, devido à concentração de atividades produtivas que aí operam descoladas de uma abordagem de sustentabilidade democrática (SANTOS e MOTTA, 2001, p.90)

Considerando a viabilidade do conceito de espaço urbano como meio ambiente artificial, é possível tratar da cidade do ponto de vista ecológico. Assim, de acordo com PAULINO (1991, p.12-13), os seres humanos que vivem numa cidade constituem um nível de organização chamado população. Uma população é formada pelo conjunto de organismos da mesma espécie que vive em uma determinada área, na mesma unidade de tempo. 
Porém, uma cidade não é constituída apenas de seres humanos: a cidade abriga diversas populações de plantas (ipês, sibipirunas, palmeiras, eucaliptos) e de animais (pardais, pombos, cães, gatos), além de inúmeros microrganismos (bactérias, protozoários). Considerando o conjunto de todas as populações que vivem na cidade, tem-se uma comunidade biológica. Na cidade, essas comunidades dependem de fatores abióticos, isto é, fatores do mundo fisico, tais como temperatura, umidade do ar e do solo, grau de luminosidade, disponibilidade de oxigênio e outros. Quando se consideram as interações estabelecidas pelos componentes do mundo vivo, entre si e com os componentes do mundo físico, tem-se um nível de organização denominado ecossistema (PAULINO, 1991, p.13).

A mata atlântica, por exemplo, é um ecossistema independente, ou seja, auto-sustentável, vez que produz o alimento necessário à manutenção de vida na comunidade. Já a cidade é um ecossistema dependente, uma vez que a energia biológica (alimentos) necessária à sua subsistência provém de outras áreas (zonas rurais) (PAULINO, 1991, p.14).

Para DREW (1998, p.177), as áreas urbano-industriais representam a mais profunda modificação humana da superficie da Terra, da atmosfera e do ecossistema terrestre. Ao contrário dos efeitos da atividade agrícola, os efeitos urbanos são altamente intensivos e localizados. Nas zonas urbanas os fluxos de energia e de massa estão concentrados, sendo a maior parte da energia importada. Com o emprego da energia e da massa há uma reversão para um estado difuso e nãoconcentrado, cuja expressão é calor e dejetos. Cerca de doze por cento da Inglaterra e Pais de Gales estão edificados, onde, portanto, existe alteração ambiental direta, mas esta atinge muitas extensões além da paisagem de concreto. Por exemplo, as alterações hidrológicas iniciadas na parte urbanizada de uma bacia hidrográfica poderiam produzir efeito a montante da corrente e ainda mais a jusante, possivelmente modificando o funcionamento de toda a bacia. As mudanças climáticas são mais evidentes na curta abóbada de ar que recobre uma cidade, mas o vento dominante leva consigo nuvens de ar poluído para muito longe. As alterações 
ecológicas provocadas por ambientes poluídos, ou de qualquer forma conturbados, espraiam-se para muito além dos limites urbanos.

Continua o mesmo autor explicando que, virtualmente, todos os aspectos do ambiente são alterados pela urbanização e a industrialização, inclusive o relevo, o uso da terra, a vegetação, a fauna, a hidrologia e o clima. Regra geral, a intensidade da mudança está ligada à densidade da área edificada e à extensão da industrialização, principalmente da indústria extrativa ou pesada. $O$ gradiente da severidade da mudança vai do interior rural, através dos subúrbios ao centro comercial ou ao núcleo industrial. As áreas urbanas horizontais, com muitos espaços verdes, costumam alterar menos o ambiente que os centros industrializados (DREW, 1998, p.177).

Para BRANCO (2007, p.209-210), o ambiente urbano representa um sistema extremamente peculiar e distinto de todos os ambientes naturais, por varias razões:

(1) Este autor considera que o ambiente urbano não constitui um verdadeiro "ecossistema", ou "ecossistema artificial". Pela simples razão de que qualquer ecossistema deve, obrigatoriamente, comporse de um componente produtor além dos componentes consumidor e decompositor que se seguem, em uma hipotética cadeia linear de alimentação. Ora, a cidade constitui um centro consumidor, por excelência. Ela absorve enormes quantidades de energia, seja na forma de eletricidade, combustíveis para automóveis, caminhões, tratores e máquinas industriais, ou de alimento, mas não produz nenhuma forma de matéria ou de energia. Só dissipa. Todas as fontes produtoras encontram-se fora da cidade, às vezes a grande distância exigindo gasto de energia inclusive para o seu transporte até o centro de consumo.

(2) A cidade não recicla nada. Ao contrario dos ecossistemas verdadeiros, em que os subprodutos metabólicos constituem nutrientes dos elementos produtores, as cidades não possuindo estes 
últimos, dispersam os nutrientes. O gás, carbônico sobe para a atmosfera, em grandes quantidades, gerando efeito estufa; os subprodutos sólidos (lixo), líquidos (esgoto) e gasosos acumulam-se no seu solo, nas águas de seus rios, lagos e mares e na sua atmosfera local, em um exemplo único de geração brutal de entropia e desorganização da energia.

(3) Ao contrário dos ecossistemas naturais, que captam energia dispersa e desorganizada e a transformam em energia concentrada e organizada, a cidade capta energia organizada (moléculas de combustíveis orgânicos) e a transforma em energia desorganizada que é dispersada.

Por sua vez, os centros produtores das formas de energia concentrada que são usados pelas cidades (fazendas, florestas, jazidas de carvão e petróleo, usinas hidrelétricas) não contam com qualquer retorno: os solos são progressivamente dilapidados de seus elementos essenciais, o que obriga a uma reposição artificial, mediante a adição de elementos obtidos com emprego de energia, como o nitrogênio retirado do ar e o fósforo obtido das rochas e tornado solúvel por reação com ácido sulfúrico. As jazidas não se recompõem e somente as usinas hidrelétricas têm o seu "capital energético" continuamente renovado, por força do ciclo hidrológico, com dispêndio de energia solar (BRANCO, 2007, p.210).

As conseqüências dessa situação, ainda conforme BRANCO (2007, p.211), além da formação continua e brutal da entropia, são as seguintes:

(1) A maioria dos seres vivos, na cidade, não se acha na sua condição "natural" (a não ser o próprio homem, se considerarmos que, paradoxalmente, a sua condição natural é a "artificial”). As árvores não têm os seus produtos reciclados, sendo nutridas artificialmente. Os pássaros que se aninham em seus ramos, alimentam-se, na maioria, de restos de alimentos das casas, não havendo, pois, aquela 
relação de reciproGidade entre planta e animal, a não ser em casos esporádicos e muito restritos.

(2) Os produtos metabólicos desse enorme "ventre" que é a cidade não retornam à sua origem, isto é, aos elementos produtores; acumulamse no solo, nos rios e no ar. Essa é uma situação de desequilibro única em toda a natureza (pelo menos em longo prazo).

(3) A dissipação contínua de energia, na forma de calor, no interior da cidade, faz com que esta tenha a sua temperatura continuamente elevada, o que dá origem às ilhas de calor, representadas por cada grande cidade em relação ao entorno, constituído de campos, pastagens ou florestas, em que há concentração de energia em lugar de dissipaçã̀o. É essa a causa das grandes diferenças (de até dez graus) que têm sido observadas, por exemplo, na cidade de São Paulo, entre seu centro urbano e as periferias, em um raio de apenas vinte quilômetros.

(4) A cidade, enfim comporta-se como um verdadeiro sumidouro de energia, matéria e trabalho, sem qualquer restituição possivel. Não é sustentável por definição, pois a sustentabilidade depende de reciprocidade, de permutas permanentes com as fontes externas e não um fluxo contínuo em uma só direção.

Não falta respeitabilidade científica aos estudos das cidades sob o ângulo ecossistêmico, como no caso de BRANCO (2007). Porém, não se deve concluir, a partir desse tipo de análise, que a cidade seja algo assemelhado ao inferno, sem nenhuma qualidade em especial que se destaque, onde não se vislumbre nenhuma saída para ao menos mitigar os seus complexos problemas. Também não se deve imaginar que a superação dos problemas urbanos passe pela mudança para o campo. Ou seja, que a cidade é um problema em si e a solução está na sua dissolução, na sua destruição. 
Quando se pensa na administração de uma cidade como-ecossistema, é preciso buscar os aspectos construtivos que podem resultar da relação interdisciplinar entre ciências biológicas (ecologia), humanas (urbanismo, arquitetura, economia) e exatas (engenharia). Dentro desse espírito, exemplifica RIBEIRO (2000, p.184), deve-se dar especial atenção às interações das cidades com as regiões que as abastecem de água, ar, alimentos, combustiveis e outras formas de energia essenciais para seu funcionamento, como também àquelas que lhes fornecem materiais, que são processados e transformados em moradias e bens de consumo. As cidades constituem um tipo de ecossistema com altíssimo grau de intervenção humana, até mesmo em suas áreas verdes, tais com parques, jardins e praças. O hábitat urbano é espaço para o desenvolvimento humano, cultural, econômico, social, espiritual. E a produção dos espaços habitados não pode perder de vista esses fundamentos.

O vínculo cultural entre os seres humanos e as cidades é indiscutível. Sabe-se que as cidades existem há milhares de anos e que ainda hoje não se avista quaisquer sinais de declínio que possam supor o seu desaparecimento próximo. Muito pelo contrário, as cidades dão mostra de grande vitalidade, haja vista que, segundo o Fundo de População das Nações Unidas, metade da população do planeta já seria urbana em 2008 e que esta chegaria a sessenta por cento até 2030 (CRUZ e RODRIGUES, 2007). Observa-se este mesmo vigor também em nosso país, eis que a população urbana brasileira em 2005 já chegava a setenta e sete por cento, ficando quase igual à população total de 1980 (SANTOS, 2005, p.31).

Com tamanha dinâmica de crescimento, não se pode ignorar a importância da vida urbana nem lhe negar qualidades. Se o meio urbano fosse tão insuportável assim, por que tantas pessoas, no mundo todo, decidem cada vez mais viver em cidades? Por insanidade mental é que não deve ser. Alguma vantagem o meio urbano deve oferecer sobre o mundó rural. Se problemas existem, e eles são graves, não há dúvida, é preciso aceitar o desafio e buscar soluções.

Apesar de sua degradação, o meio ambiente artificial tem grande importância social. Como afirma BORJA (2002), em conferência pronunciada no "Fórum Europa", em Barcelona, no mês de junho de 2001, a cidadania tem sua 
origem nas cidades, caracterizadas pela densidade, diversidade, pelo auto-governo, pelas normas não formais de convivência, abertura ao exterior. Em sintese, a cidade é intercâmbio, comércio e cultura. Não somente uma concentração física de pessoas e edifícios. É lugar de civismo, ou participação nos negócios públicos. ¿̇ lugar de política, de exercício do poder. A cidade é lugar de convivência e tolerância, mas também de conflito e de diferença.

A cidade é também ó espaço que contém o tempo, o lugar do patrimônio natural e cultural. O reconhecimento dos patrimônios, da paisagem, da arquitetura, da história, das festas e dos movimentos sociais. Ela é parte do processo de aquisição da cidadania, da construção das identidades individuais e coletivas. Conhecer e descobrir a cidade em suas múltiplas dimensões é conhecer-se a si mesmo e aos demais, é assumir-se como indivíduo e como membro de comunidades diversas. É nela que os valores, os idiomas, as culturas se encontram, podem conviver e relacionar-se (BORJA, 2002).

Um olhar retroativo sobre as cidades, como ressalta OLIVA (2005, p.73), vai nelas identificar, e só poderia ser nelas, a gestação e desenvolvimento da linguagem escrita, da ciência, das artes, da política e da filosofia. Na verdade, a cidade exerce desde a antigüidade um importante papel como ator social no desenvolvimento da civilização ocidental.

Como bem expressa JACOBS (2001, p.498), o ser humano é, em si, dificil, e portanto todos os tipos de coletividades (exceto as cidades imaginárias) têm problemas. As grandes cidades têm problemas em abundância, porque têm pessoas em abundância. Mas as cidades cheias de vida não são impotentes para combater mesmo os problemas mais dificeis. Não são vitimas passivas de uma sucessão de circunstâncias, assim como não são a contrapartida maléfica da natureza. As cidades vivas têm uma estupenda capacidade natural de compreender, comunicar, planejar e inventar o que for necessário para enfrentar as dificuldades. Talvez o exemplo mais notável dessa capacidade seja a conquista das grandes cidades diante das doenças. As cidades já foram devastadas por doenças, mas as venceram magnificamente. 
Nesse mesmo diapasão, SOUZA (2000, p.134) considera ser mais que absurdo postular que as grandes cidades geradas pela urbanização capitalista são algo absolutamente maléfico. Essa "urbanofobia", representada por alguns ecologistas fundamentalistas e, curiosamente, também por alguns geopolíticos alemães durante o III Reich, não resiste a uma apreciação séria dos fatos. Em larga medida tem de se concordar que as cidades concentram muitos problemas; por outro lado, concentram muitas chances, graças às facilidades potenciais de acesso a equipamentos de consumo coletivo (em comparação com numerosas zonas rurais do terceiro mundo) e à densidade de redes de informação.

Como comenta SILVA, M. V. (2007, p.70), observa-se certo desencanto pelo urbano, que tem sido a tônica de alguns movimentos ecológicos e de algumas vertentes do urbanismo contemporâneo. A ideologia fugere urbem pode se reproduzir em larga escala e nas manifestações as mais diversas: do condomínio fechado ao home office, da chácara de fim de semana à comunicação virtual. Em todas elas, o traço comum de negação do convívio com a alteridade, a recusa de colocar as conviç̧ões (ou apenas ilusões) à prova, a fuga a qualquer possibilidade de contato com o imprevisto, o indeterminado/incontrolado (o acaso) que representa talvez o traço mais característico da experiência urbana.

JACOBS (2001, p.495) adverte para o perigo da idealização da natureza, vista como benigna, enobrecedora e pura. Do lado oposto dessa pureza, nobreza e benignidade fíctícias, as cidades, que não são tão fictícias, poderiam ser consideradas como centros de malignidade e, obviamente, inimigas da natureza. A sentimentalização da natureza é perigosa. A maioria das idéias sentimentais envolve, no fundo, um profundo descaso, ainda que inconsciente. No entender da autora não há coincidência no fato de os norte-americanos, talvez os que mais sentimentalizem a natureza, serem ao mesmo tempo, provavelmente, os destruidores mais terriveis e insensíveis da área rural e das matas em todo o mundo.

Ainda segundo JACOBS (2001, p.495-496), não é o amor nem o respeito pela natureza que levam a essa atitude esquizofrênica. Na verdade, o que leva a isso é um desejo sentimental de se entreter, de modo bem paternalista, com um arremedo 
de natureza, suburbano, insipido, padronizado, descrendo clara e inteiramente de que os seres humanos e as cidades, pelo fato de existirem, são também parte genuína da natureza e estão envolvidos com ela de maneira muito mais profunda e inevitável que aparar a grama, tomar banho de sol e elevar o espirito pela contemplação. E assim, dia após dia, vários milhares de hectares da zona rural são destruídos por tratores, cobertos de asfalto, pontilhados de novos moradores que mataram aquilo que esperavam descobrir. A herança insubstituivel de terras agrícolas de primeira (tesouro raro da natureza da terra) é sacrificada em nome de auto-estradas ou estacionamentos de supermercados, tão impiedosa e impensadamente quanto se arrancam as árvores das florestas, poluem-se córregos e rios e enche-se o próprio ar com gases poluentes (produtos da era das fábricas da natureza), necessários neste grande esforço de se aproximar de uma natureza fictícia e fugir da "antinaturalidade" da cidade.

Cumpre salientar que, embora Jane Jacobs tenha escrito sobre fatos que ela observou nos Estados Unidos, suas críticas são pertinentes e aplicáveis a várias regiões do Brasil, em especial ao interior do Estado de São Paulo e seus condomínios fechados.

Como bem salienta SILVA, M. V. (2007, p.70), é preciso desmascarar e enfrentar esse antiurbanismo, o que significa ir de encontro aos preconceitos de classe, tentativas de segregação velada que os empreendimentos imobiliários "ecologicamente corretos" promovem e advogar uma abordagem mais solidária e humanista das "relações entre homem e natureza" nas áreas urbanas.

Também é preciso combater aquela contradição expressa por HOUGH (2004, p.05), de que em um mundo cada vez mais preocupado pelos problemas de deterioração ambiental, crise de energia, contaminação, desaparecimento de espécies da fauna e flora e das paisagens naturais e produtivas, continue-se evitando tratar do meio ambiente vital da maioria das pessoas: a própria cidade. Tradicionalmente a cidade moderna tem sido considerada como um produto de energia barata, força econômica, alta tecnologia e natureza controlada. As disciplinas responsáveis pela forma da cidade têm muito pouco a ver com as ciências naturais ou com valores 
ecológicos. Se o urbanismo deve ser concebido como a arte e a ciência dedicadas a realçar a qualidade do meio ambiente físico da cidade, a proporcionar lugares civilizados e enriquecedores para as pessoas que a habitam, não há dúvida que as suas bases atuais precisam de reexame.

Em resumo, a maldizer e abandonar as cidades em troca de uma natureza fictícia e domesticada que, no fim das contas, acaba por destruir a ordem complexa e singular da verdadeira natureza, é melhor tomar providências no sentido de melhorar o meio ambiente urbano.

\subsubsection{Estatuto da cidade}

Um importante instrumento jurídico nesse sentido é o Estatuto da Cidade (Lei 10.257 de 10/07/001). Este diploma legal fornece um instrumental a ser utilizado em matéria urbanística, sobretudo em nível municipal, visando a melhor ordenação do espaço urbano, com observância da proteção ambiental e a busca de solução para problemas sociais graves, como moradia e saneamento, que a urbanização desordenada faz incidir, de modo contundente, sobre as camadas mais carentes da sociedade (MEDAUAR, 2002, p.13).

A degradação urbana é especialmente observada nas cidades brasileiras, em razão de sua longa tradição de desenvolvimento desordenado, regulado por interesses econômicos imediatistas e ausência de planejamento urbano. Daí que os brasileiros urbanos em geral vivem mal, em cidades poluídas, congestionadas, cinzentas, carentes de verde, de saneamento básico, de transporte público, violentas, assoladas pelas favelas e cortiços, pela miséria, pelo desemprego, pela criminalidade. E é nas cidades que fica mais exposta a chaga das desigualdades sociais resultantes do injusto sistema econômico que rege a sociedade brasileira. 
O problema, como se vê, é enorme e a solução não é fácil. Trata-se de vencer uma situação que data dos tempos coloniais e que até agora não havia sido enfrentada com seriedade. Daí desponta a importância do Estatuto da Cidade, particularmente na medida em que observamos no seu bojo as diretrizes que devem nortear a política urbana, que é aquela que tem por objetivo ordenar o pleno desenvolvimento das funções sociais da cidade e da propriedade urbana (art. $2^{\circ}$, caput, do Estatuto da Cidade).

Entre as diretrizes gerais da política urbana, as mais importantes para este trabalho são: garantia do direito a cidades sustentáveis, entendido como o direito à terra urbana, à moradia, ao saneamento ambiental, à infra-estrutura urbana, ao transporte e aos serviços públicos, ao trabalho e ao lazer, para as presentes e futuras gerações (inc.I do art. $2^{\circ}$ do Estatuto da Cidade); gestão democrática por meio da participação da população e de associações representativas dos vários segmentos da comunidade na formulação, execução e acompanhamento de planos, programas e projetos de desenvolvimento urbano (inc. II); planejamento do desenvolvimento das cidades, da distribuição espacial da população e das atividades econômicas do Município e do território sob sua área de influência, de modo a evitar e corrigir as distorções do crescimento urbano e seus efeitos negativos sobre o meio ambiente (inc. IV); oferta de equipamentos urbanos e comunitários, transporte e serviços públicos adequados aos interesses e necessidades da população e às características locais (inc. V); ordenação e controle do uso do solo, de forma a evitar a deterioração das áreas urbanizadas, a poluição e a degradação ambiental (inc. VI, letras $\mathrm{f}$ e $\mathrm{g}$ ); adoção de padrões de produção e consumo de bens e serviços e de expansão urbana compatíveis com os limites da sustentabilidade ambiental, social e econômica do Município e do território sob sua área de influência (inc.VIII); proteção, preservação e recuperação do meio ambiente natural e construído e do patrimônio cultural (inc. XII); audiência do poder público municipal e da população interessada nos processos de implantação de empreendimentos ou atividades com efeitos potencialmente negativos sobre o meio ambiente natural ou construído, o conforto ou'a segurança da população (inc. XIII). 
O conceito legal de cidade sustentável decorre fundamentalmente do encontro entre os principios adotados pela Comissão Brundtland e pela Agenda 21.

A ONU criou em 1983 a Comissão Mundial sobre Meio Ambiente e Desenvolvimento, a qual foi presidida por Gro Harlem Brundtland, então primeiraministra da Noruega, pelo que ficou conhecida como "Comissão Brundtland”. Seus trabalhos foram concluídos em 1987, com a apresentação de um diagnóstico dos problemas globais. A comissão propôs que o desenvolvimento econômico fosse integrado à questão ambiental, de que resultou o chamado desenvolvimento sustentável, que recebeu o seguinte conceito: “desenvolvimento sustentável é aquele que atende às necessidades das presentes, sem comprometer a possibilidade das futuras gerações satisfazerem suas próprias necessidades" (VIEIRA, 2008, p.314).

A Agenda 21 é um plano de ação para ser adotado global, nacional e localmente, por organizações do sistema das Nações Unidas, governos e sociedade civil, em todas as áreas em que a ação humana impacta o meio ambiente. Constituise na mais abrangente tentativa já realizada de orientar o século XXI para um novo padrão de desenvolvimento, cujo alicerce é a sinergia da sustentabilidade ambiental, social e econômica, perpassando todas as suas ações propostas. A Agenda 21 Global, por sua vez, foi construída de forma consensual, com a contribuição de governos e instituições da sociedade civil de cento e setenta e nove países, em processo que durou dois anos e culminou com a realização da Conferência das Nações Unidas sobre o Meio Ambiente e Desenvolvimento (CNUMAD), no Rio de Janeiro, em 1992, onde foi aprovada (VIEIRA, 2008, p.315).

O capítulo sete da Agenda 21 Global envolve diretamente a questão da sustentabilidade urbana. Ele trata da promoção do desenvolvimento sustentável dos assentamentos humanos, estabelecendo como premissas básicas: (1) oferecer a todos habitação adequada; (2) aperfeiçoar o manejo dos assentamentos humanos; (3) promover o planejamento e o manejo sustentáveis do uso da terra; (4) promover a existência integrada de infra-estrutura ambiental: água, saneamento, drenagem e manejo de resíduos sólidos; (5) promover sistemas sustentáveis de energia e transporte nos assentamentos humanos: (6) promover o planejamento e o manejo dos 
assentamentos humanos em áreas sujeitas a desastres; (7) promover atividades sustentáveis na indústria de construção; (8) promover o desenvolvimento dos recursos humanos e da capacitação institucional e técnica para o avanço dos assentamentos humanos (VIEIRA, 2008, p.315).

Para a efetivação do Estatuto da Cidade e suas diretrizes, está prevista uma série de instrumentos em seu art. $4^{\circ}$. Tendo em vista o escopo desta tese, cumpre destacar os seguintes: plano diretor (inc. III); tombamento de imóveis ou de mobiliário urbano (inc. $\mathrm{V}$, letra $\mathrm{d}$ ); instituição de unidades de conservação (inc. $\mathrm{V}$, letra e); direito de preempção (inc. $V$, letra $m$ ); transferência do direito de construir (inc. $\mathrm{V}$, letra o); estudo prévio de impacto ambiental (EIA) e estudo prévio de impacto de vizinhança (EIV) (inc. VI).

O plano diretor, aprovado por lei municipal, é o instrumento básico da política de desenvolvimento e expansão urbana (art. 40). Ele pode ser definido como o complexo de normas legais e diretrizes técnicas para o desenvolvimento global e constante do município, sob os aspectos físico, social, econômico e administrativo, desejado pela comunidade local. Deve ser a expressão das aspirações dos munícipes quanto ao progresso do território municipal no seu conjunto cidade-campo. É o instrumento técnico-legal definidor dos objetivos de cada municipalidade e, por isso mesmo, com supremacia sobre os outros para orientar toda a atividade da administração e dos administradores nas realizações públicas e particulares que interessem ou afetem a coletividade (MEIRELLES, 1993, p.393).

O direito de preempção confere ao poder público municipal preferência para aquisição de imóvel urbano, objeto de alienação onerosa entre particulares (art. 25, caput, do Estatuto da Cidade). Lei municipal, baseada no plano diretor, deve delimitar as áreas em que incide o direito de preempção e fixar prazo de vigência, não superior a cinco anos, renovável a partir de um ano após o decurso inicial de vigência (art. $25, \S 1^{\circ}$ ). Este direito será exercido sempre que o poder público necessitar de áreas para criação de espaços públicos de lazer e áreas verdes (art. 26, inc. VI). 
Lei municipal, baseada no plano diretor, poderá autorizar o proprietário de imóvel urbano, privado ou público, a exercer em outro local ou alienar, mediante escritura pública, o direito de construir previsto no plano diretor ou em legislação urbanística dele decorrente, quando o referido imóvel for considerado necessário para fins de preservação, em razão de seu interesse histórico, ambiental, paisagístico, social ou cultural (art. 35, caput e inc. II).

O estudo de impacto de vizinhança pode ser definido como um documento técnico onde constam informações concernentes aos mais variados aspectos decorrentes da implantação e/ou alteração de fatos urbanos significativos, destinado a instruir autoridades publicas e população, para avaliação da compatibilidade e adequação dessa implantação com suas áreas de entorno imediato e, extensivamente, com toda a cidade (Souza, apud ROCCO, 2006, p.25). A principal característica do estudo de impacto de vizinhança é a democratização das decisões proferidas sobre a possibilidade de instalação, ou não, de determinados empreendimentos a serem realizados na cidade (ROCCO, 2006, p.25).

O estudo de impacto de vizinhança deve ser executado de modo a contemplar os efeitos positivos e negativos do empreendimento ou atividade quanto à qualidade de vida da população residente na área e suas proximidades, incluindo a análise, no mínimo, das seguintes questões: adensamento populacional; equipamentos urbanos e comunitários; uso e ocupação do solo; valorização imobiliária: geração de tráfego e demanda por transporte público; ventilação e iluminação; paisagem urbana e patrimônio natural e cultural (art. 37, caput, incs. I a VII). 
4.5.3. Cidades saudáveis e qualidade de vida

O Programa das Cidades Saudáveis da Organização Mundial da Saúde, por sua vez, lida com o conceito de cidade saudável. Uma cidade saudável é aquela que coloca em prática de modo contínuo a melhoria do meio ambiente físico e social, utilizando todos os recursos de sua comunidade. Portanto, considera-se uma cidade ou município saudável aquele em que os dirigentes municipais enfatizam a saúde de seus cidadãos dentro de uma ótica ampliada de qualidade de vida (CANEPA, 2007, p.172).

Mas o que significa qualidade de vida? Como afirma Vargas (apud VARGAS e RIBEIRO, 2001, p.19), temos aqui uma ampla discussão. O significado de qualidade de vida urbana tem atores diferentes, com interesses, objetivos e expectativas também diferentes. $\mathrm{O}$ quadro individual e subjetivo altera-se com $\mathrm{o}$ tempo, à medida que as mudanças da sociedade acontecem e os repertórios individual e coletivo se ampliam.

Em relação ao conceito de qualidade de vida, Cutter (apud. VARGAS e RIBEIRO, 2001, p.15) propõe o uso de indicadores de três ordens: sociais, ambientais e perceptivos. Aos dois primeiros elementos dá também uma dimensão perceptiva, isto é, de bem-estar ou não em relação a um elemento objetivo. Essa autora procura avaliar as condições objetivas também a partir da imagem subjetiva do indivíduo e de suas expectativas em relação ao lugar. A qualidade do meio ambiente é julgada mediante valores da sociedade. Acredita que as avaliações de qualidade de vida devem iniciar-se pela caracterização do meio ambiente urbano: a história, o quadro socioeconômico e cultural da população, seus aspectos físicos, recursos disponiveis, elementos poluentes etc. A abordagem holística teria como objeto de análise a cidade inserida num contexto cultural e subjetivo.

Segundo Hippel (apud DERANI, 2008, 59), a qualidade de vida coloca-se no nivel dos super-objetivos da política informadora do direito, junto com os direitos, deveres e valores fundamentais. Assim, a antiga questão da felicidade tem agora um renascimento mundial sob o novo título de qualidade de vida. O mesmo autor destaca 
os pontos mais importantes para a construção da qualidade de vida: liberdade, segurança, trabalho, educação, nível de vida, entorno físico, entorno social, saúde, justiça.

Do ponto de vista do ordenamento juridico brasileiro, qualidade de vida, no dizer de DERANI (2008, p.59), apresenta dois aspectos concomitantes: nivel de vida material e bem-estar físico e espiritual. Uma sadia qualidade de vida abrange esta globalidade, acatando o fato de que um mínimo material é sempre necessário para o deleite espiritual. Não é possível conceber, tanto na realização das normas de direito econômico com nas normas de direito ambiental, qualquer rompimento desta globalidade que compõe a expressão "qualidade de vida", muitas vezes referida por sua expressão sinônima "bem estar". A mesma autora ainda acrescenta a estas duas expressões sinônimas, a expressão utilizada por Aristóteles, "bem viver", encontrada em sua Política, quando trata do dinheiro e da insuficiência da sua conquista para a realização de um "bem viver". Este bem traduziria a possibilidade efetiva de o cidadão desenvolver suas potencialidades. Em suma, o conjunto de normas voltadas à consecução do bem-estar ou da melhoria da qualidade de vida, atualmente, procura uma aproximação da ética do "bom viver" de Aristóteles.

Em síntese, López Ramón, apud MACHADO (2005, p.121), enxerga a qualidade de vida como um elemento finalista do poder público, onde se unem a felicidade do indivíduo e o bem comum, com o fim de superar a estreita visão quantitativa, antes expressa no conceito de nível de vida. 
4.5.4. Vegetação e qualidade de vida urbana

\subsubsection{Benefícios físicos e biológicos}

A vegetação urbana pode mitigar muitos dos impactos ambientais resultantes do desenvolvimento urbano. Ela tempera o clima, conserva a energia, o dióxido de carbono e a água; melhora a qualidade do ar; reduz as enxurradas pluviais e as inundações; diminui os níveis de ruído e proporciona habitat para a fauna silvestre. Através do adequado planejamento, desenho e manejo da vegetação, o meio físico urbano e, conseqüentemente, a saúde e o bem-estar dos habitantes das cidades podem ser melhorados (NOWAK et al, 1998, p.18).

\subsection{Mudanças microclimáticas}

Ao transpirar água, modificar as velocidades do vento, sombrear superficies, alterar o armazenamento e intercâmbio de calor entre superficies, as árvores afetam o clima local, de modo a reduzir o uso de energia em edifícios, assim como melhorar o conforto térmico humano e a qualidade do ar (Heisler et al, apud NOWAK et al, 1998, p.18-19).

As árvores, especialmente as de copas densas, têm um impacto significativo sobre a velocidade e a direção do vento, maior do que aquelas de pequenos diâmetros e colocadas numa mesma direção (Heisler et al, apud NOWAK et al, 1998, p. 19). Numa vizinhança residencial da Pensilvânia central com sessenta e sete por cento de cobertura arbórea, a velocidade dos ventos dois metros acima do 
nível do solo foi reduzida em sessenta por cento no inverno e sessenta e sete por cento no verão, em comparação com a velocidade dos ventos em áreas similares sem árvores (Heisler, apud Idem).

As árvores também têm uma importante influência sobre a radiação solar que se dirige ao solo. Assim, estas podem reduzi-la em noventa por cento ou mais (Heisler, apud NOWAK et al, 1998; p.19). Parte da radiação absorvida pela cobertura arbórea provoca a evaporação e a transpiração da água das folhas. Esta evapotranspiração baixa a temperatura das folhas, da vegetação e do ar. Apesar das grandes quantidades de energia utilizadas na evapotranspiração em dias ensolarados, os movimentos do vento dispersam rapidamente o ar esfriado, reduzindo o efeito global do calor. Debaixo de árvores individuais ou de pequenos grupos, a temperatura do ar, a um metro e meio acima do nível do solo, sofre usualmente uma variação média de $1^{\circ} \mathrm{C}$, em comparação com a temperatura do ar numa área aberta (Souch e Souch, apud Idem). Juntamente com o esfriamento provocado pela evapotranspiração, a sombra das árvores também auxilia a esfriar o ambiente urbano, na medida em que evita o aquecimento solar de algumas superficies artificiais que estão debaixo da cobertura arbórea (edificios, casas). Estes efeitos conjuntos podem reduzir a temperatura do ar em até $5^{\circ} \mathrm{C}$ (Akbari et al, apud Idem).

As baixas temperaturas do ar podem igualmente melhorar a sua qualidade. A redução na temperatura do ar corresponde à diminuição da emissão de muitos contaminantes. Estas baixas temperaturas também reduzem o $\mathrm{O} 3$ (ozônio) fotoquímico (Cardelino e Chameides, apud NOWAK et al, 1998, p.20). Além de proporcionar esfriamento por transpiração, a massa fisica e as propriedades térmicoradioativas das árvores atuam sobre outros aspectos da meteorologia local, tais como velocidade do vento, umidade relativa, turbulência e altura das camadas térmicas limítrofes, o que acarreta a redução da concentração de contaminantes em áreas urbanas (NOWAK et al, 1998, p.20). 
4.5.4.1.2. Conservação de energia e dióxido de carbono

As árvores podem reduzir as necessidades de energia para esquentar e esfriar edifícios, sombreando e reduzindo a temperatura do ar no verão e bloqueando os ventos no inverno. O consumo de energia numa casa de quintal arborizado pode ser vinte ou vinte e cinco por cento menor do que numa casa similar em espaço aberto (Heisler, apud NOWAK, 1998, p.20-21). Foi estimado que o plantio de cem milhões de árvores ao redor de residências nos Estados Unidos poderia economizar dois bilhões de dólares pela redução no consumo de energia (Akbab et al, apud Idem).

Um dos principais problemas ambientais das cidades são as emissões de gases de efeito-estufa, como o dióxido de carbono (CO2). Estas emissões originamse das diferentes formas de combustão que se produzem nos centros urbanos e que alcançam um volume considerável de alta concentração. Uma cidade desenvolvida, de dimensões médias, produz entre três e oito toneladas de $\mathrm{CO} 2$ anuais por pessoa, das quais o tráfego de veículos representa cerca de quarenta por cento. Uma cidade européia com uma população de um milhão de habitantes, por exemplo, gera a cada dia vinte e cinco mil toneladas de dióxido de carbono devido ao uso de combustiveis fósseis. As árvores consomem boa parte desse dióxido de carbono e produzem grandes quantidades de oxigênio. Por exemplo, um álamo branco (espécie de árvore), de vinte e quatro metros de altura e diâmetro de copa de quinze metros produz oxigênio necessário para a respiração de dez pessoas (FALCÓN, 2007, p.25-26).

A vegetação arbórea urbana pode ainda reduzir o $\mathrm{CO} 2$ atmosférico, armazenando diretamente carbono (do $\mathrm{CO} 2$ ) em sua biomassa, enquanto a árvore cresce. As árvores grandes, de pelo menos setenta e sete centímetros de diâmetro, armazenam mil vezes mais carbono que as pequenas, de diâmetros menores que sete centímetros (Nowak, apud NOWAK et al, 1998, p.21). As árvores sãs continuam fixando carbono adicional a cada ano; as grandes e vigorosas fixam cerca de noventa vezes mais que as pequenas (Idem). 
Cumpre salientar que, na medida em que as árvores forem morrendo, o carbono nelas fixado será liberado de volta à atmosfera, mediante decomposição (NOWAK et al, 1998, p.21). Daí que para se manter o nível de fixação de carbono, necessário se faz manejar a vegetação de modo a conservar constante a cobertura verde.

\subsection{Remoção de contaminantes do ar}

As árvores removem a contaminação dos gases do ar, primariamente através dos estômatos das folhas, ainda que algumas substâncias contaminantes sejam removidas pela superfície das plantas (Smith, apud NOWAK et al, 1998, p.22). Uma vez que estão no interior das folhas, os gases difundem-se nos espaços intercelulares e são absorvidos por películas de água para formar ácidos ou reagir nas superfícies internas das mesmas. Os espécimes arbóreos também eliminam a contaminação interceptando partículas transportadas pelo ar. Algumas partículas podem ser absorvidas dentro das árvores (Ziegler; Rolfe, apud Idem), apesar de que a maioria é retida na superfície da planta. Neste caso, trata-se de um abrigo temporário, já que as partículas podem voltar a ficar suspensas na atmosfera, levadas pela chuva, ou cair no solo com as folhas e ramos (Smith, apud Idem).

Estima-se que, apenas em 1991, a vegetação arbórea de Chicago tenha removido aproximadamente quinze toneladas métricas de monóxido de carbono $(\mathrm{CO})$, oitenta e quatro de dióxido de enxofre ( $\mathrm{SO} 2$ ), oitenta e nove de óxidos de nitrogênio (NOx), cento e noventa e uma de ozônio (O3) e duzentas e doze toneladas de partículas menores que dez micra. Na região de Chicago, nos condados de Cook e Du Page, as árvores removeram uma quantidade estimada em cinco mil, quinhentas e setenta e cinco toneladas de contaminantes (Nowak, apud NOWAK et al, 1998, p.23). 
Nas zonas onde se desenvolve uma concentração humana tão grande como nas cidades, o ar apresenta uma quantidade considerável de microorganismos patogênicos. Os indices de presença desses organismos variam em função das características do espaço urbano: quantidade de pessoas, capacidade do vento para renovar o ar e presença ou ausência de plantas. Numa área edificada e concorrida, como podem ser os arredores de um centro comercial, a concentração de elementos patogênicos pode chegar a quatro milhões de unidades por metro cúbico de ar. Já numa zona arborizada, a capacidade da folhagem para fixar a poeira pode reduzir essa concentração para trinta mil unidades por metro cúbico. Por sua vez, num parque urbano que conte com árvores adultas e, certamente, com uma menor pressão humana, a redução pode chegar a mil unidades por metro cúbico (FALCÓN, 2007, p.30-31).

\subsection{Hidrologia urbana}

Ao interceptar e reter ou diminuir o fluxo de precipitação pluvial que chega ao chão, as árvores urbanas (conjuntamente com os solos) cumprem importante função nos processos hidrológicos urbanos. Podem reduzir a velocidade e o volume do escoamento superficial (enxurrada) resultante de uma tempestade, como também os danos por inundações e a contaminação da água disponivel. $O$ escoamento superficial estimado para o evento de uma tempestade em Dayton, Ohio, mostrou que a cobertura arbórea (vinte e dois por cento) foi responsável pela sua redução potencial em sete por cento. Um incremento modesto de cobertura arbórea (para vinte e nove por cento) reduziria o escoamento superficial em cerca de doze por cento (Sanders, apud NOWAK et al, 1998, p.24). Para otimizar estes beneficios hidrológicos, a cobertura arbórea deve ser incrementada onde estiver relativamente baixa e nos locais onde haja extensas superficies de solo impermęável (NOWAK et al, 1998, p.24). Ainda do ponto de vista hidrológico, a vegetação urbana pode trazer proteção da qualidade e capacidade de reservação de água, proteção das nascentes e 
áreas de mananciais. Daí resulta maior qualidade e quantidade de água disponível (FURLAN, 2004, p.257).

Define-se erosão como o desprendimento e transporte de detritos devidos aos agentes que operam sobre a superfície terrestre. A força da gravidade transporta estes materiais aos níveis mais baixos e tende a igualar as saliências dos terrenos até convertê-los em plano. Um dos agentes que mais produzem erosão é a chuva, devido á energia de suas gotas. Nas cidades a erosão somente afeta as superfícies desprovidas de qualquer tipo de pavimentação ou construção, mas seus efeitos podem ser importantes em áreas extensas de terreno livre, onde provoca perda de solo e de nutrientes, assim como um efeito estético negativo pela aparição de fraturas, valos e desníveis (FALCÓN, 2007, p.29).

A vegetação tem função de estabilização do relevo (proteção contra deslizamentos, especialmente os de origem pluviométrica), de que resulta um maior controle de riscos ambientais, de enchẹtes e ação restauradora em áreas degradadas (FURLAN, 2004, p.257). Isto ocorre, especialmente, pela fixação do solo com plantas baixas, vez que evitam a incidência direta da água sobre o solo. Elas contribuem para fixar a terra graças a seu sistema radicular pouco profundo e muito denso. Os arbustos também são bastante indicados para esta função. As árvores, ao contrário, ao desenvolverem raizes mais profundas, não conseguem fixar a terra da superficie, porem reduzem substancialmente a força da chuva, vez que a filtram através da folhagem (FALCÓN, 2007, p.29).

\section{5..4.1.5. Redução do ruído}

Uma das agressões mais graves originada das cidades é a contaminação acústica. $\mathrm{O}$ ruído, ainda que menos alarmante que a contaminação atmosférica, pode provocar doenças quando supera um nível determinado. A principal fonte de ruído 
urbano é o tráfico rodado, mais do que o gerado por indústrias ou atividades em via pública. A densidade de edifícios em ruas estreitas multiplica este efeito. O excesso de ruído deve ser combatido pela redução das fontes do mesmo, mediante o uso de veículos mais silenciosos e o controle do nível sonoro de certas atividades, por exemplo. Além disso, a contaminação acústica pode ser reduzida com barreiras sônicas que isolem o indivíduo da fonte de ruídos (FALCÓN, 2007, p.29).

Provas de campo demonstraram que a plantação de árvores e arbustos apropriadamente desenhada reduz de maneira significativa o ruído. As folhas e ramos reduzem o som transmitido, principalmente dispersando-o, enquanto o solo efetua a sua absorção (Aylor, apud NOWAK et al, 1998, p.25). Para obter uma ótima redução de ruido, as árvorẹs devem ser plantadas na proximidade da sua fonte produtora e não da área receptora (Cook; Van Haverbeke, apud Idem). Cinturões largos (trinta metros) de árvores altas e densas, combinados com superfícies suaves de solo, podem reduzir os sons aparentes em cinqüenta por cento ou mais (Cool, apud Idem). Para espaços de plantação estreitos (menos de três metros de largura), a redução de ruído, de três a cinco decibéis, pode ser obtida com a utilização de cinturões de vegetação densa, de uma fileira de arbustos ao lado da estrada e uma fileira de árvores atrás (Reethof; Mcdaniel, apud Idem).

\subsection{Benefícios ecológicos}

Muitos benefícios adicionais estão associados à vegetação urbana e contribuem para o funcionamento dos ecossistemas urbanos a longo prazo e para o bem-estar dos residentes urbanos. Entre os beneficiários estão o habitat da fauna silvestre e a biodiversidade enriquecida.

As pesquisas realizadas concluem que a maioria dos habitantes da cidade gozam e apreciam a fauna em suas vidas diárias (Shaw et al, apud NOWAK et al, 
1998, p.26). Ademais, a criação e enriquecimento do habitat usualmente aumenta a biodiversidade e complementa muitas outras funções benéficas dos parques urbanos (Johnson et al, apud Idem). Devido ao aumento da consciência ambiental e do interesse pela qualidade de vida, é provável que haja um incremento do significado dos benefícios ecológicos com o tempo (Dwyer et al, apud Idem).

\subsubsection{Beneficios socioeconômicos}

A arborização urbana também tem efeitos significativos no meio socioeconômico de uma cidade. Estes benefícios freqüentemente são muito mais dificeis de medir e quantificar, mas são tão ou até mais importantes.

4.5.4.2.1. Benefícios econômicos de ambientes agradáveis

A presença de árvores e parques urbanos pode fazer do ambiente da cidade um lugar mais prazeroso para viver, trabalhar e utilizar o tempo livre. Os estudos sobre preferências e condutas dos habitantes urbanos confirmam a forte contribuição que as árvores e os parques trazem à qualidade de vida urbana. Os parques urbanos facilitam o uso do tempo ao ar livre e dão oportunidades de recreação. A contribuição total das árvores, parques urbanos e áreas recreativas, ao valor total de experiências de recreação efetuadas nos Estados Unidos excede dois bilhões de dólares (Dwyer, apud NOWAK et al, 1998, p.26-27). 
4.5.4.2.2. Saúde mental e fisica

A diminuição da pressão (stress) e a melhoria da saúde fisica dos residentes urbanos associa-se à preservação de árvores e parques urbanos. Os estudos a respeito mostram que as paisagens com árvores e outros tipos de vegetação produzem estados fisiológicos de mais relaxamento nos seres humanos que aquelas que carecem destas caracteristicas naturais. Foi demonstrado que os pacientes de hospital com visão de árvores de suas janelas recuperam-se significativamente mais rápido e com menos complicações que aqueles sem tal vista (Ulrich, apud NOWAK et al, 1998, p.27).

As áreas verdes valorizam esteticamente o meio urbano, aumentam a satisfação da vida diária e criam uma relação significativa entre as pessoas e o meio natural. As árvores contribuem para a qualidade estética das ruas residenciais e parques comunitários (Schroeder, apud NOWAK et al, 1998, p.27). A percepção de qualidade estética e de segurança pessoal estão relacionados às características do parque urbano, tais como o número de árvores por acre e distância visual (Schroeder; Anderson, apud Idem). Os espécimes arbóreos e parques urbanos promovem experièncias emocionais e espirituais significativas que são extremamente importantes na vida das pessoas e podem conduzir a um forte enraizamento a lugares específicos e suas árvores ( Chenoweth e Gobster; Dwyer et al; Schroeder, apud NOWAK et al, 1998, p.27-28).

Ainda quando seja vista desde a janela de um escritório, a natureza próxima pode proporcionar beneficios psicológicos substanciais, melhorando a satisfação e o bem-estar no trabalho (Kaplan, apud. NOWAK et al, 1998, p.28). Ficou demonstrado que as experiências nos parques urbanos ajudam a mudar estados de ânimo e a reduzir o stress (Hull, apud Idem). Adicionalmente, a sombra das árvores reduz a radiação ultravioleta e dessa maneira pode ajudar a reduzir problemas de saúde, como catarata e câncer na pele (Heisler et al, Idem). 


\subsection{Valorização da propriedade}

$\mathrm{O}$ valor de mercado reflete as qualidades que os adquirentes atribuem aos imóveis, inclusive quanto à vegetação que os cerca. Os construtores civis estimam que as residências com lotes arborizados são vendidos a preços sete por cento maiores que aqueles sem arborização (Selia e Anderson, apud NOVAK et al, 1988, p.28).

Os parques e corredores verdes estão associados ao incremento no valor das propriedades residenciais próximas (Corrill et al; More et al, apud NOVAK et al, 1988, p.29). Um estudo concluiu que o valor das propriedades próximas ao Pennypack Park em Filadélfia é incrementado de mil dólares por acre $(40,47$ ares), a uma distância de dois mil e quinhentos pés (76.200 metros) da área verde, para onze mil e quinhentos dólares por acre a quarenta pés (1.216 metros) do parque (Hammer et al, apud WALKER, p.01). Outro estudo concluiu que o preço da propriedade residencial, baseado em dados de três bairros de Boulder, Colorado, decrescia US\$ 4,20 por pé $(30,48 \mathrm{~cm})$ que se distanciava do cinturão verde (Correll et al, apud WALKER, p.01).

Porém, é possível que os parques tenham impacto negativo sobre o valor dos imóveis próximos, na medida em que não recebam manutenção adequada ou concentrem atividades criminais indesejáveis (NOWAK et al, 1998, p.29). 


\subsection{Desenvolvimento econômico local}

Os parques urbanos contribuem amplamente para a vitalidade econômica de uma cidade, distrito ou bairro. Ainda que seja dificil de quantificar, não parece acidental que muitas cidades e logradouros tenham obtido suas denominações de árvores (o próprio Brasil). As árvores podem dominar o ambiente da cidade e contribuir significativamente para o caráter da mesma. Os programas de ação comunitária que se iniciam envolvendo árvores e bosques costumam se expandir para outros aspectos da comunidade e resultam no incremento do desenvolvimento econômico. Com freqüência as árvores e bosques situados em terras públicas e, em alguma medida, em áreas privadas, também representam recursos significativos de "propriedade comum" que contribuem para a vitalidade econômica de uma região (Dwyer et al, apud NOWAK, 1998, p.29).

\subsection{Benefícios sociais}

Os parques urbanos podem criar excelentes oportunidades para crianças de todas as idades desenvolverem talentos que poderão ser utilizados para dirigir suas futuras vidas de modo gratificante. Assim, parques podem oferecer programas que não se resumam a diversão, mas que também auxiliem crianças e jovens a adquirir vantagens nos quatro campos de ação mais importantes para um desenvolvimento saudável: fỉsico, intelectual, emocional e social (WALKER, p.02).

Por exemplo, o Garfield Park Conservatory Alliance, organização sem fins lucrativos que participa da gestão do District's Garfield Park Conservatory em Chicago, estabeleceu um programa inovador orientado para a comunidade, onde um grupo de estudantes organiza anualmente um projeto de exposição permanente de 
jardinagem. Os estudantes trabalham como verdadeiros jardineiros, exercitando sua inteligência e criatividade em equipe, onde desenvolvem modelos, determinam um orçamento e coletivamente escolhem o projeto vencedor (WALKER, p.02).

A programação do North Meadow Recreation Center, no Central Park de Nova York, serve de outro exemplo. Este centro coordena, juntamente com escolas locais e grupos comunitários, o ensino de anatomia básica e práticas saudáveis, além de proporcionar atividades físicas interativas. A equipe utiliza várias abordagens para estimular a auto-estima entre os estudantes que freqüentam os cursos. Instrutores ensinam atividades como arbitragem de basquete e escalada de muros. Este último, inclusive, é um esporte que exige espírito de equipe e auxílio mútuo para a prática segura (WALKER, p.02).

Os parques podem oferecer empregos de longa duração para as comunidades residentes no seu entorno, como também valiosas oportunidades de treinamento conjunto entre jovens e adultos, para unir mão-de-obra, talento e experiência (WALKER, p.02).

A mesma Garfield Park Alliance oferece um programa de docência com dois anos de duração que auxilia a preparar adolescentes da zona oeste de Chicago para a vida após o término do ensino médio. O programa básico de treinamento enfatiza o desenvolvimento de liderança, de habilidades pessoais e sociais e preparo profissional. Seus participantes começam a trabalhar como docentes no Garfield Park Conservatory, fazendo exposições aos visitantes do parque. A Alliance também trabalha em conjunto com a prefeitura para empregar jovens aprendizes como artistas na criação de obras de arte (WALKER, p.02).

Os freqüentadores dos parques urbanos podem muito bem ser engajados em programas de promoção de exercícios saudáveis para jovens e idosos. Um estudo efetuado em Cleveland confirma a expectativa de que os parques promovam a saúde para os americanos de cinqüenta anos ou mais (Payne et al, apud WALKER, p.03).

Hearts N' Parks, um programa comunitário sustentado pelo National Heart, Lung and Blood Institute e pela National Recreation and Park Association, é 
um bom exemplo de programa inovador voltado para a saúde. Este programa foi lançado inicialmente em dois locais: Carolina do Norte e Condado de Arlington na Virgínia. O projeto da Virgínia, lançado em 2000, dirige-se às crianças, jovens e idosos nos acampamentos de verão, parques e centros de recreação. Uma pesquisa entre os participantes concluiu que os jovens sabiam mais sobre hábitos alimentares saudáveis e que os adultos tinham realmente tornado sua alimentação mais saudável (WALKER, p.03).

Em adição às tangíveis contribuições ao desenvolvimento dos jovens, oportunidades de emprego e saúde pública, os parques urbanos podem contribuir para a construção e fortalecimento dos laços entre as comunidades residentes no seu entorno, unindo pessoas, inclusive aquelas que de outra forma estariam divididas por raça ou classe, e ajudando-as a trabalhar em projetos comuns. Estes laços, freqüentemente rotulados com "capital social”, representam sutis, mas importantes vantagens para a comunidade. Eles proporcionam espaços através dos quais fluem informações, valores e expectativas sociais e ainda estimulam as pessoas a enfrentarem problemas que lhe são comuns, embarcarem em ações coletivas e defenderem efetivamente a sua comunidade (WALKER, p.03).

O Prospect Park, no Brooklyn (Nova York), proporciona um excelente exemplo de como parques urbanos podem ajudar pessoas a trabalhar conjuntamente em prol de metas comuns. O Community Advisory Comitee, com cerca de noventa membros, representa um largo espectro de organizações e interesses da vizinhança do parque. Esta entidade reúne-se mensalmente e mantém quatro grupos de trabalho: operações, defesa, educação e eventos especiais. Doze servidores municipais também comparecem a essas reuniões (WALKER, p.03).

Além das numerosas ações voltadas a cursos educativos e em prol da obtenção de recursos públicos, o Comitee tem fortalecido, através da participação no parque, os laços de muitos grupos étnicos e raciais por todo o Brooklyn. A título de exemplo, a realização no parque do festival Boricua estimulou a organização de um grupo comunitário para planejar e arrecadar fundos para futuros festivais (WALKER, p.03). 


\subsubsection{Indicadores de vegetação urbana}

O indicador mais tradicional para se verificar a situação da vegetação de um determinado centro urbano é aquele que é calculado com base no número de metros quadrados de áreas verdes por habitante. Segundo BILLAUDOT e BESSONGUILLAUMOT (1979, p.519), o objetivo a ser alcançado no meio urbano é de dez metros quadrados por habitante, definido por grupo de trabalho sobre espaços verdes da Organização Mundial da Saúde em 1972. De acordo como os mesmos autores. este grupo ainda determinou para os espaços de final de semana (espaços préurbanos florestados) a meta de vinte e cinco metros quadrados por habitante.

Conforme BILLAUDOT e BESSON-GUILLAUMOT (1979, p.519-520), Paris e seus subúrbios em 1979 não possuíam mais que 3,6 metros quadrados de áreas verdes por habitante. Para Toulouse a cifra seria de 0,3 , de 5 para Roma, 8 para Moscou, 9 para Nova York e Londres, 50 para Washington, 123 para Dortmund. Cumpre salientar que tais cifras, mesmo correspondendo aproximadamente à realidade, não são suficientes para mensurar a satisfação ambiental dos habitantes dessas cidades. Assim, Viena, com seus 25 metros quadrados de áreas verdes por habitante, oferece um ambiente urbano muito mais satisfatório que Los Angeles com seus 150 , onde reina o urbanismo linear (a negação da cidade).

A própria definição de "áreas verdes" ou "espaços verdes" é motivo de enormes polêmicas, como veremos em maiores detalhes no próximo capítulo. Mas BUCCHERI FILHO e NUCCI (2006, p.50) buscam conceituar áreas verdes como um tipo especial de espaço urbano ao ar livre, onde o elemento fundamental da composição é a vegetação. Elas devem satisfazer três objetivos principais: ecológico-ambiental, estético e de lazer. Vegetação e solo permeável devem ocupar ao menos setenta por cento da área; devem servir à população. Portanto, segundo esses autores, canteiros, pequenos jardins de ornamentação, rotatórias e arborização nào podem ser considerados áreas verdes, mas sim "verde de acompanhamento 
viário", que com as calçadas, pertencem à categoria de espaços construídos ou espaços de integração urbana.

Tendo em vista a insuficiência desse indice de áreas verdes por habitante, necessário se faz buscar outros indicadores que possam ao menos complementá-lo. Destarte, Oke, apud BUCCHERI FILHO e NUCCI, 2006, p.50, estima que um indice de cobertura vegetal na faixa de trinta por cento seja recomendável para proporcionar um adequado balanço térmico em áreas urbanas. Já áreas com arborização inferior a cinco por cento determinam características semelhantes às de um deserto. Para o cálculo do indice de cobertura vegetal, que não é o de áreas verdes, segundo Nucci e Cavalheiro, apud NUCCI (2008, p.30), devem ser levadas em conta todas as manchas de vegetação, inclusive as copas das árvores.

A cidade ideal, segundo Sukopp e Werner, apud BUCCHERI FILHO e NUCCI (2006, p.50), ou seja, aquela que apresentaria as condições ideais para a conservação da natureza e da paisagem, poderia edificar ou pavimentar, aproximadamente, dois terços da superfície do centro, ou seja, trinta e três por cento da área central da cidade deveria ser permeável e não edificada, além de apresentar ampla conexão entre a vegetação da zona rural e a das zonas centrais.

Indicadores usados em diversos paíšes procuram levar em conta, além do mínimo de área verde por habitante, o seu tamanho mínimo, raio de influência, posição no território, faixas etárias, o tipo de uso, entre outros fatores (NUCCI, 2008, p.31).

Destarte, em Washington, DC, os parques urbanos são classificados em seis tipos. A um destes tipos deve corresponder determinada área (em metros quadrados) por habitante; dimensões individuais (mínimas e máximas); população servida (usuários) e área servida (raio de utilização), conforme Bannon, apud NUCCI (2008, p.137):

(1) playlets: $\mathrm{m}^{2} / \mathrm{hab}: \mathrm{n} / \mathrm{c}$; dimensões: entre 232,20 e $4.047,80 \mathrm{~m}^{2}$; população servida: 500 a 2.500 habitantes; área servida: subvizinhança; 
(2) vest pocket parks: $\mathrm{m}^{2} / \mathrm{hab}: \mathrm{n} / \mathrm{c}$; dimensões: entre 232,20 e $4.047,80$ $\mathrm{m}^{2}$; população servida: 500 a 2.500 habitantes; área servida: subvizinhança;

(3) parques de vizinhança: $\mathrm{m}^{2} / \mathrm{hab}: 10,11$; dimensões: entre 20.233,90 e $80.935,60 \mathrm{~m}^{2}$; população servida: 2.000 a 10.000 habitantes; área servida: 402,30 a $804,50 \mathrm{~m}$;

(4) parques distritais: $\mathrm{m}^{2} / \mathrm{hab}$ : 10,11; dimensões: entre $80.935,60 \mathrm{e}$ $404780,00 \mathrm{~m}^{2}$; população servida: 10.000 a 50.000 habitantes; área servida: 804,50 a $4,8 \mathrm{~km}$

(5) grandes parques urbanos: $\mathrm{m}^{2} / \mathrm{hab}$ : 20,23; dimensões: mais de $404.780 \mathrm{~m}^{2}$ : população servida: um p/cada 50.000 habitantes; área servida: meia hora de auto;

(6) parques regionais: $\mathrm{m}^{2} /$ hab: 80,93 ; dimensões: mais de $1.011 .950 \mathrm{~m}^{2}$ : população servida: populações inteiras de pequenas comunidades; área servida: uma hora de auto.

No Canadá, por sua vez, existem padrões gerais a serem aplicados às áreas verdes urbanas. São cinco tipos de parque urbano. De forma semelhante a Washington, DC, a cada um dos tipos deve corresponder uma área por habitante, raio de utilização e dimensões determinadas (NUCCI, 208, p.138):

(1) espaços de recreação de subvizinhança: $\mathrm{m}^{2} / \mathrm{hab}: \mathrm{n} / \mathrm{c}$; raio de utilização: 30 a 400 m; dimensões: 46,45 a $8.000 \mathrm{~m}^{2}$;

(2) parques e espaços de recreação de vizinhança: $\mathrm{m}^{2} / \mathrm{hab}: 4$ a 10 ; raio de utilização: 400 a 800 m; dimensões: 1.000 a $80.000 \mathrm{~m}^{2}$;

(3) parques e campos de recreação distritais: $\mathrm{m}^{2} / \mathrm{hab}: 4$ a 10 ; raio de utilização: 800 m a $5 \mathrm{Km}$; dimensões 1,6 a 40 ha; 
(4) grandes parques urbanos: $\mathrm{m}^{2} /$ hab: 20 ; raio de utilização: mais de 5 $\mathrm{Km}$ ou meia hora de auto; dimensões 10 a 80 ha;

(5) parques regionais: $\mathrm{m}^{2} / \mathrm{hab}: 16$ a 40 ; raio de utilização: mais de uma hora de auto; dimensões: mais de 40 ha.

4.5.6. Indicadores de verde urbano em São Paulo

A cidade de São Paulo teve sua ocupação caracterizada pela expansão e especulação imobiliária. Este parece ser um fenômeno característico de cidades em que o forte caráter especulativo de valorização da terra conduziu a expansão urbana. A cobertura vegetal, que perdeu lugar para a especulação da terra, consolidada em toda a cidade, raras vezes foi considerada como fator importante na estruturação urbana. A vegetação de campos úmidos das várzeas, as matas das colinas deram lugar inicialmente a loteamentos (regulares e clandestinos), distritos industriais, grandes avenidas e recentemente a centros de compras, de eventos, de distribuição de mercadorias, etc. (FURLAN, 2004, p.263).

A supressão das diferentes tipologias de vegetação arbórea e de campos colaborou para a desorganização do relevo original do sitio urbano, contribuiu para intensa erosão do solo, mudou o microclima e a dinâmica das bacias hidrográficas da cidade. Cortes, aterros, cavas de areia e reorganização da drenagem para o sistema viário são eventos que também colaboraram para a supressão da vegetação (FURLAN, 2004, p.256).

Já segundo o Plano de Avenidas, elaborado por Prestes Maia em 1930 (apud SÃO PAULO, 2004, p.53), o índice de áreas verdes por habitante em São Paulo era de apenas 0,71 m2/hab. Em 1947 ele era estimado em pouco mais de 0,5 m2/hab (SOCIEDADE AMIGOS DA CIDADE, 1950, p.06). Portanto, já se tratava de uma cidade extremamente carente de áreas verdes de uso público. 
Para uma cidade ambientalmente tão degradada, há tanto tempo, era de se esperar que, no mínimo, fossem cuidadosamente estudados indicadores que pudessem determinar com alguma precisão o nível de carência de áreas verdes, de modo a dar suporte a políticas públicas que pudessem mudar esse quadro dramático. Mas isto infelizmente não ocorre.

Basta notar os índices de áreas verdes em metros quadrados por habitante no Município de São Paulo mencionados a seguir: 4,48 (Gêiser et al, 1975); 8,73 (PMSP-COGEP, 1975); 3,38 (Wilheim et al, 1985); 4,37 (PMSP, 1988); 8,00 (Troppmair, 1989); 1,80 (DAEE in SN, 12/08/1990); 4,00 (FSP, 29/12/1991); 3,50 (FSP, 07/04/1994) ${ }^{3}$. Como se vê, num período de dezenove anos (1975-1994) temos os números mais díspares. Torna-se difícil falar em índices de área verde no Município de São Paulo, já que cada fonte apresenta índices diferentes para o męsmo período. Ou, o que é tão grave quanto, a mesma fonte apresenta índices diferentes para idêntico período de estudo (NUCCI, 2008, p.29).

Como afirma Custódio (apud NUCCI, 2008, p.29), inexiste em São Paulo uma estimativa real de metros quadrados de área verde por habitante, advertindo-se que a que tem sido publicada fundamenta-se em mecanismos errôneos, que incluem para este efeito todo e qualquer espaço livre, sem características de vegetação. Ora, áreas verdes propriamente ditas não se confundem com espaços ou áreas livres, uma vez que, na maioria destes últimos não existe uma só árvore, um único espécime vegetal. A estimativa real de metros quadrados por habitante, baseada nas raras e últimas áreas verdes existentes na capital paulista, seria, sem dúvida, alarmante.

$\mathrm{O}$ próprio conceito de área verde já se constitui num problema. $\mathrm{O}$ antigo Plano Diretor do Município de São Paulo (Lei Municipal 10.676, de 07/11/1988), em seu art. 37, classificava as áreas verdes em "de propriedade pública" e "de propriedade privada". As primeiras eram: áreas para recreação, parques de vizinhança, praças, campos esportivos ou centros desportivos municipais, centros educacionais esportivos, parques distritais e reservas naturais. As segundas eram:

\footnotetext{
${ }^{3}$ Referências apud NUCCI (2008, p.29).
} 
clubes esportivos sociais, clubes de campo e áreas arborizadas (SÃO PAULO, 2004, p. 100). Como se pode ver, a natureza destas áreas verdes é essencialmente urbana.

Já o atual Plano Diretor Estratégico do Municipio de São Paulo (Lei Municipal 13.430, de 13/09/2002), em seu art. 132, incs. I e II, considera também integrantes do sistema de áreas verdes as unidades de conservação do SNUC, situadas no Município de São Paulo, as quais, como vimos anteriormente, têm caracteristicas eminentemente rurais.

Destarte, a simples mudança de plano diretor implica num considerável aumento dos espaços verdes da cidade sem que tenha sido plantada uma única árvore!

Assim, conforme estudo realizado em 1992 pela própria prefeitura municipal, incluindo áreas verdes rurais (PMSP, apud NUCCI, 2008, p.29), chegouse a um índice de $4,4 \mathrm{~m} 2$ de áreas verdes públicas por habitante. $\mathrm{O}$ mesmo cálculo, efetuado com base apenas nas áreas verdes urbanas (considerando que 97,5\% da população paulistana reside em zona urbana), o mesmo índice seria de apenas $2,9 \mathrm{~m} 2$ por habitante (NUCCI, 2008, p.29-30).

NUCCI (2008, p.30-31) constata ainda que a metodologia aplicada a áreas verdes na cidade de São Paulo limita-se a classificar o que existe, sem buscar realmente criar um "sistema de áreas verdes". Assim, nem o plano diretor anterior, nem o atual, conta com recomendações quanto ao mínimo de metros quadrados por habitante, tamanho mínimo de cada tipo de área verde, raio de influência, posição no território, faixas etárias, o tipo de uso, etc.

Por todo o exposto, a realidade das áreas verdes paulistanas é melhor retratada quando, ao invés de nos preocuparmos em demasia com o índice de metros quadrados por habitante, buscamos observar os levantamentos realizados por satélite. Ficamos então sabendo que quarenta e oito por cento do território do município apresenta carência significativa de cobertura vegetal de qualquer tipo, seja ela na forma de maciços vegetais significativos, arborização viária ou áreas verdes (parques urbanos e praças). Por outro lado, trinta e três por cento do municipio é coberto por 
maciços florestais em diversos estágios de sucessão ecológica, sendo que os distritos de Parelheiros, Marsilac, Grajaú, Jardim Ângela, Jaçanã-Tremembé e Perus, submetidos a intensa pressão para a ocupação, concentram setenta e cinco por cento desse tipo de vegetação (SÃO PAULO, 2004, p.71).

\subsection{PARQUES URBANOS}

\subsubsection{Conceitos de parque urbano}

Conceituar parque urbano é um trabalho dificil, na medida em que não existe disposição legal estabelecida a respeito. Mesmo entre profissionais que lidam diretamente com a questão, como urbanistas, paisagistas, arquitetos, geógrafos entre outros, surgem divergências. Aliás, estas atingem também outros conceitos próximos, tais como espaços livres, áreas verdes, praças, arborização urbana, áreas abertas, áreas livres e espaços abertos.

É importante destacar que essa imprecisão de conceitos não é um problema estritamente brasileiro, mas ocorre também em outros países. ZAMORA et al (2003, p.162), em trabalho que visa estudar cento e oito parques em vinte e três municípios da Comunidade de Madri, destacam a dificuldade de se chegar a uma definição de "parque urbano". De um lado muitas são as expressões utilizadas para espaços ajardinados urbanos: zona verde, espaços livres, verde público, parque, jardim, etc. Por outro lado, muitas são as definições de parque estabelecidas nas publicações sobre o tema, em função de objetivos concretos de estudo. Do ponto de vista do planejamento urbanístico, falta homogeneidade e determinação nos aspectos considerados (tamanho, função, desenho, etc.) pelas diversas tipologias de zonas 
verdes estabelecidas nos planos de ordenação urbana. Ressaltam esses autores que a consulta de alguns dos mais recentes desses planos (Madri, Alicante, Málaga) confirma que seu conteúdo não permite demarcar suficientemente o conceito: não são unânimes quanto ao tamanho manejado, no que tange às questões relacionadas com sua fisionomia (espaços ajardinados ou florestados, ou ainda onde predomine a vegetação natural), nem mesmo no que diz respeito aos seus equipamentos.

Em Portugal também se observam as mesmas dificuldades. Assim, as "Normas para programação de equipamentos coletivos" do Gabinete de Estudos e Planejamento da Administração do Território, Ministério do Planejamento e da Administração do Território, de 1990, definem o parque urbano como inserido na estrutura verde principal da cidade, destinando-se ao recreio, lazer e convívio da população "inter-bairros”. É um espaço verde bastante construído, com uma área superior a três hectares, equipado com mobiliário urbano e desportivo. No entanto, existe outra definição, também oficial, mais exigente, contida nas "Normas urbanísticas: princípios e conceitos fundamentais", da Direção-Geral do Ordenamento do Território e Desenvolvimento Urbano e Universidade Técnica de Lisboa, que entende ser o parque urbano um espaço decodificado, no qual se desenvolve uma poética do sublime e um sentido de interioridade que exige uma superficie útil superior a trinta hectares e uma incompatibilização total com a instalação de mobiliário e equipamento de qualquer tipo (apud CESUR, p.43). Como se vê, segundo um conceito o parque urbano pode ter porte menor e deve estar bem equipado com mobiliário urbano e desportivo. Já pelo outro, o parque urbano deve ter porte mínimo dez vezes maior e nenhum equipamento urbano. Temos aqui duas definições bem distintas, quase opostas, porém ambas com origem pública.

BALZA (1998, p.32) apresenta uma proposta de conceito para espaço urbano de uso público ou espaço aberto urbano. Este, segundo a acepção anglosaxônica do termo,

pode ser definido como aquele espaço de propriedade pública ou privada, que é de livre acesso, ainda que não necessariamente gratuito, à população de uma cidade, vila ou bairro, para que esta possa desenvolver atividades sociais, culturais, 
educacionais, de contemplação e recreação. É importante estabelecer que o acesso a ditos espaços não é necessariamente contínuo, a qualquer hora do dia ou da noite, ou em qualquer dia da semana e o caráter dos mesmos não é necessariamente verde.

BALZA (1998, p.32) entende ainda que para se poder formular uma definição de espaço urbano de uso público, faz-se necessário estabelecer claramente suas funções que ele resume em oito:

(1) recreação, isto é, a realização de atividades desportivas formais e não formais, os jogos e a participação em atividades ao ar livre;

(2) estruturação da forma urbana. O autor cita casos como o do Parque Metropolitano e o Cerro Santa Lúcia em Santiago do Chile, que são elementos centrais que trazem um caráter peculiar às cidades;

(3) estética. O espaço público embeleza os corredores viários e conjuntos habitacionais, que valoriza os investimentos imobiliários e comerciais;

(4) contemplação. É um uso do espaço público que se encontra particularmente ausente da legislação urbana, podendo estabelecer-se certos critérios visando a eliminação da contaminação visual em zonas de uso misto comercial, industrial e residencial, além de gerar barreiras ao ruído, como resultado da função refratária da vegetação;

(5) planejamento dos panoramas. É outro aspecto pouco experimentado nas cidades, particularmente do terceiro mundo. Um exemplo patético, citado pelo autor, é da eliminação da.vista do poente desde - Cerro Santa Lúcia de Santiago, em razão da construção de edificações de grande altura. Este tipo de situação constitui um desaproveitamento de potencial turístico, além de perda de oportunidades econômicas, culturais e educacionais para a cidade, seus habitantes e visitantes, ao reduzir a atração de um espaço público de alto valor histórico; 
(6) uso social e cultural. Este uso encontra-se bastante reconhecido, ainda que seja pouco regulamentado, ficando tal regramento por conta das municipalidades [Chile].

(7) uso educacional. Este uso do espaço público é algo que se deixou para a iniciativa de particulares, seja mediante a criação de parques zoológicos, jardins botânicos, ou, em menor escala, por conta das escolas de ensino básico, com o uso intensivo e organizado dos espaços públicos, como extensão e complemento dos programas educativos escolares. $O$ desenvolvimento desta função pode contribuir para a obtenção de fundos extraordinários para a construção e manutenção dos espaços públicos, provenientes de fontes públicas e privadas. Adicionalmente, o efeito de vincular estreitamente a educação formal com o uso dos espaços públicos, pode trazer grandes benefícios em matéria de reconhecimento e cuidado dos referidos espaços pelo cidadão comum, além da sua consolidação, no sentido de apropriação afetiva pelos moradores do bairro, região e cidade em geral.

(8) ecológica. Uma última, porém não menos relevante função. Deve-se reconhecer o papel do espaço público em questões como o regime dos ventos e a temperatura média, onde os espaços verdes e o desenho urbano exercem uma função determinante.

Richter, apud GERALDO (1997, p.40), propõe a seguinte classificação para os espaços livres e o verde urbano:

(a) jardins de representação e decoração: ligados à ornamentação, de reduzida importância com relação à interação com o meio e sem função recreacional. São jardins à volta de prédios públicos, igrejas, etc.

(b) parques de vizinhança: praças, playgrounds; apresentam função recreacional, podendo abrigar alguns equipamentos; 
(c) parques de bairro: são áreas ligadas à recreação, com equipamentos recreacionais, esportivos dentre outros, que requerem maiores espaços do que os parques de vizinhança;

(d) parques setoriais ou distritais: áreas ligadas à recreação com equipamentos que permitam que tal atividade se desenvolva;

(e) áreas para proteção da natureza: destinadas à conservação, podendo possuir algum equipamento recreacional para uso pouco intensivo;

(f) áreas de função ornamental: áreas que não possuem caráter conservacionista; são canteiros de avenidas e rotatórias;

(g) áreas de uso especial: jardins zoológicos e jardins botânicos;

(h) áreas para esportes;

(i) ruas de pedestres.

Llardent conceitua as seguintes expressões (apud LOBODA e DE ANGELIS, 2005, p.132):

(a) sistemas de espaços livres: conjunto de espaços urbanos ao ar livre destinados ao pedestre para o descanso, o passeio, a prática esportiva e, em geral, o recreio e entretenimento em sua hora de ócio;

(b) espaços livres: quaisquer das distintas áreas verdes que formam o sistema de espaços livres;

(c) zonas verdes, espaços verdes, áreas verdes, equipamentos verdes: qualquer espaço livre no qual predominam as áreas plantadas de vegetação, correspondendo em geral, ao que se conhece como parques, jardins ou praças. 
Milano, apud VIEIRA (2004, p.21), entende que áreas verdes e arborização urbana são conceitos de grande correlação e proximidade. Arborização urbana é o conjunto de terras públicas e privadas com vegetação predominantemente arbórea ou em estado natural que uma cidade apresenta. Por outro lado, adaptações do conceito de espaços livres consideram estes como áreas verdes quando predominantemente não impermeabilizados e/ou com significativa cobertura vegetal.

Para Hamburgo, na Alemanha, as áreas verdes e de recreação pública são aquelas que servem à saúde e recreação da população, mantidas pela Cidade Livre e Hanseática de Hamburgo e reconhecidas como verdes pelo Senado, através de órgãos públicos competentes. Dentro de tal conceito, incluem-se áreas com vegetação que façam parte de equipamentos urbanos, parques, jardins, cemitérios, "Kleingarten" (pequenos jardins), alamedas, bosques, praças de esporte, playgrounds, playlots (campos de jogos), balneários, campings e margens de rios e lagos (Jantzen apud LIMA et al, 1994, p. 543).

Já para Senna (apud. VIEIRA, 2004, p.20), as áreas verdes formam um conjunto de três segmentos individualizados, mas que estabelecem interligações notáveis entre si: (1) áreas verdes públicas, compostas pelo rol de logradouros públicos destinados ao lazer e à recreação ou que criem oportunidades de encontro e convívio direto com espaços não construídos e arborizados; (2) áreas verdes privadas, compostas por remanescentes vegetais significativos incorporados aos interstícios da malha urbana, que podem ter sua utilização normatizada por legislação específica que garanta ao máximo a sua conservação; (3) arborização de ruas e vias públicas. E é entre as áreas verdes públicas que iremos encontrar os parques urbanos.

Por sua vez, Henke-Oliveira, apud VIEIRA (2004, p.21), define-as como o espaço onde há o predomínio de vegetação arbórea: engloba as praças, os jardins públicos e os parques urbanos. Os canteiros centrais e trevos de vias públicas, que têm apenas função estética e ecológica, devem também conceituar-se como área verde. Entretanto, este autor entende que as árvores que acompanham o leito das vias públicas não devem ser consideradas como tal. 
O Plano Diretor Estratégico do Município de São Paulo (Lei 13.430, de 13/09/2002) define áreas verdes como o conjunto de espaços arborizados e ajardinados, de propriedade pública ou privada, necessários à manutenção da qualidade ambiental urbana e ao desenvolvimento sustentável do município (art. 101, $\S 2^{\circ}$, inc. III). Entre estes espaços estão os parques urbanos, classificados entre as áreas verdes públicas, de uso sustentável (art. 132, inc. II, letra f c.c.art. 133, inc I, letra b).

Buscando fornecer subsídios para dirimir tais problemas conceituais, LIMA et al (1994, p.539-553), integrantes da Sociedade Brasileira de Arborização Urbana, realizaram extensa revisão da literatura técnica a respeito e enviaram cento e noventa e duas cartas-consulta a diversas entidades que trabalham, pesquisam ou utilizam os conceitos aqui enfocados. Como resultado foi obtido o seguinte:

(a) espaço livre deve ser considerado o conceito mais abrangente, integrando os demais e contrapondo-se a espaço construído. Assim a floresta amazônica não se inclui nessa categoria; já a floresta da Tijuca, localizada dentro da Cidade do Rio de Janeiro, é um espaço livre. Tal conceito tem que ser integrado ao uso do espaço, sua escala e função, devendo, devendo esta última satisfazer três objetivos principais: ecológico, estético e de lazer. Entre os espaços livres temos:

(b) área verde: onde há predomínio de vegetação arbórea; engloba as praças, os jardins públicos e os parque urbanos. Os canteiros centrais e trevos de vias públicas, que têm apenas funções estética e ecológica, devem também ser conceituados como área verde. Entretanto, as árvores que acompanham o leito das vias públicas, não devem ser consideradas como tal. Como todo espaço livre, segundo Gröning apud LIMA et al (1994, p.54l) as áreas verdes também devem ser hierarquizadas, segundo sua tipologia (privadas; potencialmente coletivas, tais como clubes, escolas; e públicas) e categorias, das quais algumas são descritas a seguir: 
(c) parque urbano: é uma área verde, com função ecológica, estética e de lazer, com uma extensão maior que as chamadas praças e jardins públicos;

(d) praça: como área verde tem a função principal de lazer. Uma praça, inclusive, pode não ser uma área verde, quando não tem vegetação e é impermeabilizada (caso das praças da Sé e Roosevelt, na cidade de São Paulo); no caso de ter vegetação é considerada jardim, como é o caso do jardim para deficientes visuais ou mesmo o jardim japonês, entre outros, presentes no Parque do Ibirapuera.

(e) arborização urbana: diz respeito aos elementos vegetais de porte arbóreo, dentro da urbe, tais como árvores e outras. Nesse enfoque, as árvores plantadas em calçadas, fazem parte da arborização urbana, porém, não integram o sistema de áreas verdes.

Outros termos como área aberta e área livre, segundo os mesmos autores, deveriam

ter sua utilização evitada pela imprecisão resultante de sua aplicação. Ao se utilizar a palavra área está se relacionando apenas as dimensões largura e comprimento. Por sua vez a utilização de espaço é mais abrangente, pois dela depreende-se uma terceira dimensão, quando se trabalha com o real (LIMA et al, 1994, p.548).

A expressão espaço aberto (“open space") é empregada na Inglaterra, conforme Eckbo e Bannon (apud LIMA et al, 1994, p.542-543) e ainda BALZA (1998, p.28-29), primordialmente com o significado de área verde voltada para a recreação. No Brasil, ela significa simplesmente um espaço livre de impedimento de visão, pelo que não se recomenda sua utilização (LIMA et al, 1994, p.548).

Com relação à quantificação do tamanho dos espaços livres, LIMA et al (1994, p.548) não chegam a uma conclusão, haja vista a excessiva subjetividade de 
todos os trabalhos envolvendo a questão, o que evidencia a necessidade de outros estudos que venham elucidá-la.

Em 1999, Cavalheiro et al, apud. BUCCHERI FILHO e NUCCI (2006, p.49-50) sugeriram alguns tópicos para uma outra tentativa de padronização. Com tal finalidade, deve-se entender que uma zona urbana é composta por três sistemas: (a) sistema de espaços com construções (habitação, indústria, comércio, hospitais, escolas, etc.); (b) sistema de espaços livres de construção (praças, parques, águas superficiais, etc.); (c) sistema de espaços de integração urbana (rede rodoferroviária).

O espaço livre de construção é definido como espaço urbano ao ar livre, destinado a todo tipo de utilização que se relacione com caminhadas, descanso, passeios, práticas de esportes e, em geral, a recreação e entretenimento em horas de ócio; os locais de passeios a pé devem oferecer segurança e comodidade com separação total da calçada em relação aos veículos; os caminhos devem ser agradáveis, variados e pitorescos; os locais por onde as pessoas se locomovem por meios motorizados não devem ser considerados como espaços livres. Os espaçoslivres são privados, potencialmente coletivos ou públicos e podem desempenhar, principalmente, funções estética, de lazer e ecológico-ambiental, entre outras (Cavalheiro et al, apud BUCCHERI FILHO e NUCCI, 2006, p.50).

As áreas verdes são um tipo especial de espaços livres onde o elemento fundamental de composição é a vegetação. Elas devem satisfazer três objetivos principais: ecológico-ambiental, estético e de lazer. Vegetação e solo permeável-(sem laje) devem ocupar, pelo menos, setenta por cento da área; devem servir à população propiciando um uso e condições para recreação. Canteiros, pequenos jardins de ornamentação, rotatórias e arborização não podem ser considerados áreas verdes, mas sim "verde de acompanhamento viário", que com as calçadas (sem separação total em relação aos veículos) pertencem à categoria de espaços construídos ou espaços de integração urbana (Cavalheiro et al, apud BUCCHERI FILHO e NUCCI, 2006, p.50). 
Cobertura vegetal é a projeção do verde em cartas planimétricas e pode ser identificada por meio de fotografias aéreas, sem auxílio de estereoscopia. A escala da fotografia deve acompanhar os índices de cobertura vegetal; deve ser considerada a localização e a configuração das manchas em mapas. Considera-se toda a cobertura vegetal existente nos três sistemas (espaços construídos, espaços livres e espaços de integração) e as encontradas nas unidades de conservação, que na sua maioria restringem o acesso ao público, inclusive na zona rural (Cavalheiro et al, apud BUCCHERI FILHO e NUCCI, 2006, p.50).

Como se pode observar, esta proposta não faz distinção entre parques urbanos e praças.

Feitas tais considerações, tratemos diretamente do conceito de parque urbano, que também apresenta aspectos de tormentosa dificuldade, como podemos ver nos entendimentos dos diversos autores, estudos técnicos e textos legais mencionados a seguir.

Segundo KLIASS (1993, p.19), parques urbanos são espaços públicos com dimensões significativas e predominância de elementos naturais, principalmente cobertura vegetal, destinados à recreação.

Eckbo, apud MARIANO (1992, p.17-18), conceitua parques como espaços livres para determinados usos de forma flexível, desenvolvidos com o mínimo de edificações e o máximo de materiais naturais não processados, que visam o relaxamento, contemplação, socialização (...). Os parques são projetados procurando diferentes níveis de relações entre homem e natureza nas quais os ajustamentos se dão de ambas as partes.

Olmstead, o paisagista responsável pelo projeto do Central Park de Nova York, apud MARIANO (1992, p.18), restringia o sentido do termo parque a uma larga extensão de área tratada para que a população usufrua da paisagem campestre de maneira a distingui-lo da praça pública, jardim público, passeio público, adequados para uma maior amenização urbana. Seus parques procuravam o 
tratamento do espaço como cenário, a paisagem desejada e projetada com intensa valorização do aspecto pictórico.

CORONA (2002, p.06), define parque urbano como um espaço aberto de uso público, no qual se estabelecem relações humanas de entretenimento, recreação, esporte, convivência comunitária, educação e cultura dentro da cidade. Expressam em concreto uma das formas de relação sociedade-natureza. Por um lado, são regidas por leis biológicas e por outro, têm uma função social. Tais espaços recreativos formam parte das áreas verdes no contexto urbano. Eles são resultados da atividade prática do homem, pois contêm um componente natural (flora e fauna) e outro sociocultural, que reflete a cosmovisão, costumes e tradições da sociedade.

FALCÓN (2007, p.46), conceitua parques urbanos como aquelas zonas verdes urbanas com mais de um hectare de superficie e que disponham de equipamento básico de uso social. Os parques contam com uma cobertura vegetal importante, em que domina o estrato arbóreo, mas também apresentam uma presença considerável de arbustos e gramados. $\mathrm{O}$ interior dos parques urbanos é formado por diversos recantos que acolhem equipamentos e atividades variadas. Suas dimensões e presença de abundante vegetação permitem um isolamento quase total dos ruídos exteriores, o que proporciona bem-estar a seus usuários. No geral, seu raio de influência é mais amplo do que o bairro em que se situam e recebem visitantes de outros locais da cidade.

Noguera, apud ALBUQUERQUE (2006, p.102-103), entende que parques urbanos são espaços concebidos especificamente para facilitar a presença de vegetação na cidade, compatível com o uso de intensidade moderada pelos cidadãos. A diferenciação entre jardins [praças] e parques é pouco relevante. Logicamente os parques, por serem maiores, possuem uma configuração autônoma, enquanto que os jardins costumam estar mais integrados na trama urbana.

Já Carneiro e Mesquita, também apud ALBUQUERQUE (2006, p.104), definem os parques urbanos como espaços livres públicos com função predominante de recreação, ocupando na malha urbana uma área em grau de equivalência superior 
a uma quadra típica urbana, em geral apresentando componentes da paisagem natural (vegetação, topografia, elemento aquático), como também edificações destinadas a atividades recreativas, culturais e/ou administrativas. Noutra ocasião, Carneiro, apud ALBUQUERQUE (idem), ressalta que, considerados até pouco tempo no Brasil como espaços destinados a atender basicamente a função de recreação da população das cidades, os parques urbanos, hoje, ampliam não só seu uso, mas também o seu papel no contexto social e ambiental, passando a ser conhecidos como espaços educativos, sociais e que proporcionam um ambiente mais saudável para a cidade.

Barcellos, apud, SANTOS, (2006, p.30), apresenta três definições para parque: grandes espaços livres em que predominam os elementos naturais, áreas verdes; espaços livres públicos para o lazer e para a recreação; área em que predominam árvores, em contraste com a massa edificada da cidade. O mesmo autor alerta que o critério de dimensões tem se tornado muito arbitrário, haja vista a redução que vem ocorrendo no tamanho dos parques, resultante da crescente pressão imobiliária e especulativa sobre o solo urbano.

Trabalho elaborado pelo Department of Planning and Development e pelo Department of Park and Recreation de Toronto, Canadá, apud SCALISE (2002, p.18), define parque urbano como um grande espaço aberto público, que ocupa uma área de pelo menos um quarteirão urbano, normalmente vários, localizado em torno de acidentes naturais, por exemplo ravinas, córregos, etc. fazendo divisa com vários bairros; os limites principais de um parque urbano são ruas, sua organização espacial (paisagem) apresenta um equilíbrio entre áreas pavimentadas e ambiências naturais. $\mathrm{O}$ parque urbano pode abrigar o uso informal, de passagem, caminhos secundários de pedestres, esportes recreativos, centros comunitários, festivais, playgrounds, piscinas, etc.

Para a cidade de Bogotá, de acordo com SILVEIRA (2003, p.79), parque urbano é o espaço verde, de uso coletivo, que atua como regulador do equilíbrio ambiental; é elemento representativo do patrimônio natural e se destina ao lazer: atividades esportivas, contemplativas e culturais dos citadinos. 
Um curioso conceito nos é fornecido pela postura municipal de Seixal (Portugal) sobre espaços verdes, parques urbanos e jardins (SEIXAL). Nela parques urbanos são áreas de domínio público com ocupação diversificada de espécies vegetais, zonas ajardinadas e zonas recreativas, podendo incluir infra-estrutura comercial e espaços destinados a cónvívio social, sendo permitido o pisoteio das zonas relvadas (grifos nossos). Cumpre ressaltar que o pisoteio não é admitido nos denominados jardins e canteiros, que possuem áreas restritas para a circulação de pedestres.

Pelo Sistema Estadual de Unidades de Conservação da Bahia (SOCIEDADE MUNDIAL DE PROTEÇÃO ANIMAL, 2006), parques urbanos são espaços abertos destinados ao lazer, educação, saúde da população e à conservação dos recursos ambientais, considerando-se para sua criação, os atributos naturais, culturais, sociais, históricos, paisagísticos e cênicos.

Segundo o Sistema Municipal de Unidades de Conservação de Goiânia, em fase de minuta de projeto de lei (GOIÂNIA), parque urbano é a unidade de conservação cujo objetivo básico é tornar compatível a implantação de equipamentos sociais que propiciem o lazer, a educação e o entretenimento à população e a recuperação e a preservação de áreas verdes urbanas.

MACEDO e SAKATA (2002, p.14), consideram como parque todo espaço de uso público destinado à recreação de massa, qualquer que seja seu tipo, capaz de incorporar intenções de conservação e cuja estrutura morfológica é autosuficiente, isto é, não é diretamente influenciada em sua configuração por nenhuma estrutura construída em seu entorno. A partir disso, espaços como o Parque Buenos Aires, em São Paulo, que apesar de possuírem hoje uma relativa independência formal de seu entorno, não podem ser considerados parques pela limitação de sua área em abrigar equipamentos de lazer, tanto em quantidade como em diversidade. Desse modo, muitos dos atuais parques de pequeno porte não passam realmente de praças de vizinhança, sendo denominados parques em virtude da falta de consenso sobre o assunto entre os especialistas, dentro e fora do poder público. 
Os mesmos autores ressaltam que no decorrer do século $\mathrm{XX}$ a função tradicional do parque urbano, voltada ao lazer contemplativo, foi acrescida de várias outras, entre as quais as de conservação dos recursos naturais, típicas dos parques ditos ecológicos e as de lazer sinestésico dos brinquedos eletrônicos e dos espaços cenográficos dos parques temáticos (MACEDO e SAKATA, 2002, p.13).

MACEDO e SAKATA (2002, p.14) mencionam também a imprecisão do conceito de parque urbano no Brasil. Muitas vezes espaços de lazer de pequeno porte, dez mil m2 ou um pouco mais, são denominados parques apenas porque são cercados, contêm instalações de lazer e alguma vegetação. Outras definições consideram parque todo espaço público de lazer ou de conservação que contém vegetação, qualquer que seja o seu porte, seja um pátio ou uma área com milhares de metros quadrados.

Posição semelhante é adotada por ALBUQUERQUE (2006, p.105). Ao analisar as diversas definições, esta autora observa que os parques urbanos possuem muitas diferenças entre si, no que diz respeito às dimensões, formas, funções, conteúdo. Algumas definições de parques urbanos dão mais ênfase à questão ambiental, outras à recreação ou ao aspecto social. Em relação à dimensão, há autores que consideram parques a partir de uma quadra urbana e outros apenas como um espaço amplo. Os equipamentos previstos para os parques são os mais diversos possiveis.

Desta forma, continua ALBUQUERQUE (2006, p.105-106), percebe-se que não apenas as formas dos parques urbanos se diferenciam, mas também seus usos e funções. Ao longo de sua formação e da construção de suas definições, os parques se confundem com outras tipologias de espaços livres públicos, como jardins, praças, passeios públicos, entre outros. Isso está relacionado com as peculiaridades de cada parque, refletindo sua dinâmica e o contexto em que se situa, além do momento em que foi idealizado, projetado ou modificado, tornando-se muito difícil elaborar uma definição homogênea de parque urbano. 
Em complemento, a referida autora afirma que cada cidade tem relações específicas com os parques. Porém, antes de tudo, estes são a representação da natureza em um contexto urbano, ou seja, a tentativa de reprodução de um ambiente natural em um espaço artificial. Assim, os parques não deixam de ser um ambiente produzido pelo homem, pois nele a natureza encontra-se aprisionada e é manipulada de acordo com as suas necessidades. (ALBUQUERQUE, 2006, p.106).

\subsubsection{Parques urbanos através da história}

O parque público, enquanto espaço público urbano, é uma criação do século XVII, como expressa SEGAWA (1996, p.31-32), uma antítese bem educada e disciplinada à relativa anarquia popular que era característica da praça de origem medieval.

O plantio de árvores em espaço público não se situava entre as idéias renascentistas. É uma exceção o caso de Antuérpia, que apresentava na lateral de sua catedral uma área ornamentada com árvores, conforme planta da cidade de 1569. Este espaço, valorizado por edificações construídas por grandes mercadores, ficou conhecido com a denominação inédita para a época de Groenplaats (praça verde). $\mathrm{Na}$ mesma Antuérpia, em 1578, o conselho municipal determinava o plantio de três linhas de árvores nos passeios. As fortificações da cidade, com largas vias de circulação sobre os muros, serviram para receber moinhos e transeuntes encantados pela atração do lugar, ornamentado de árvores (Girouard, apud SEGAWA, 1996, p.38-39).

Em I597 o florentino Raphael Salvety obtinha uma concessão das autoridades de Paris para utilizar um terreno do lado externo dos muros norte da cidade (Porte Saint Honoré) para implantar um campo de "pallamaglio", esporte de origem italiana, precursor do críquete, praticado no verão sob a sombra das árvores. 
Em razão do sucesso do empreendimento, do lado oposto da cidade foi construído outro campo, entre o Sena e os muros do Arsenal. Duas avenidas arborizadas organizavam o espaço: uma destinada ao jogo e outra destinada aos espectadores e para passeios. (Girauard, apud SEGAWA, 1996, p.39). Em 1616, seria a vez do Cours de la Reine, também em Paris, recinto cercado e isolado por fossos, onde por cerca de mil e quinhentos metros, entre o Sena e a futura área dos Champs Élysées e do lado oeste das Tulherias, quatro fileiras de olmos serviam de cenário para a rainha e a elite caminharem ou circularem em carruagens, sob a sombra das árvores (Grand Larousse, apud SEGAWA, 1996, p.39).

Em 1631, o Cardeal de Richelieu ordenou a construção de novas muralhas em Paris, por trás das quais deveria haver uma muralha de terra plantada com árvores, podendo servir de passeio, à maneira de Antuérpia. $\mathrm{O}$ aproveitamento das áreas das muralhas ganhou mais expressão com a remodelação das defesas fortificadas em meados do século XVII, ao leste e ao norte da cidade, onde a área ao longo das muralhas foi transformada em importante passeio arborizado (Grand Larousse, apud SEGAWA, 1996, p.40). Outras avenidas arborizadas foram implantadas: o Cours Vincennes, em 1660, ligando o palácio real e o parque em Vincennes, com um bem arborizado local chamado Lê Trône, criado para o casamento de Louis XIV; os Champs Elysées em 1670, no eixo do jardim das Tulherias, paralelo ao Cours de la Reine (Larousse, apud SEGAWA, 1996, p.40).

Por sua vez, dois processos distintos marcaram a criação dos primeiros parques ingleses. Em primeiro lugar, pela absorção dos grandes espaços, representados pelos jardins dos palácios reais que foram abertos ao público e incorporados à estrutura urbana (KLIASS, 1993, p.20). A partir de 1649, os parques reais, como Whitehall, Hampton Court, Westiminster Palace, Greenwich Park, entre outros foram franqueados ao público pelo parlamento. $O$ principal deles, o Hyde Park, aberto entre 1630 e 1640, abrigava uma pista utilizada para corridas de cavalo e velocistas. Foi a introdução do "pallamaglio" na Inglaterra de Carlos II que originou o recanto conhecido como Pall Mall (nome em inglês do jogo), ou simplesmente Mall, no atual Saint James Park, originalmente um alagadiço utilizado 
para caça, melhorado por volta de 1660 com arborização para atender essa diversão (SEGAWA, 1996, p.43).

Conforme Laurie, apud MARIANO (1992, p.23), os parques pertencentes à coroa britânica ocupavam uma extensão significativa de Londres, apesar das localizações e projetos não guardarem relação com as necessidades da população. Porém, pela extensão de suas áreas criou-se no centro da cidade uma atmosfera de jardim urbano ao alcance de uma ampla faixa da população.

Outra forma de inserção dos parques nas cidades inglesas, que marcou sobremaneira sua paisagem urbana, deve-se aos empreendimentos imobiliários promovidos pela iniciativa privada. Exemplos desse processo são as inúmeras "squares", o Buxton Pavilion Gardens (1871) e o Birkenhead Park (1847), de autoria de Joseph Paxton (KLIASS, 1993, p.20).

Informa FALCÓN (2007, p.21-22), que, em 1850, o arquiteto paisagista norte-americano Frederick Law Olmstead, em visita ao Birkenhead Park, ficou impressionado com o seu desenho e o espírito democrático que norteava seus usos, de modo que o mais humilde camponês era tão livre para usufruir de todas as partes do parque quanto a rainha da Inglaterra. Ao retornar aos Estados Unidos, conforme BARIDON, Olmsted buscaria criar parques para sociedades democráticas.

Após o grande incêndio de 1666, Londres conheceu uma grande expansão de sua área urbanizada. Foi então introduzida a denominada "square" nas áreas livres resultantes da urbanização promovida por grandes proprietários de terras nas cercanias da cidade. A "square" inglesa era um recinto ajardinado e cercado, embutido numa trama de ruas residenciais ostentando construções uniformes. Elas não se confundiam com as praças tradicionais. Seu acesso era permitido apenas aos moradores das adjacências, pessoas de mesmo nível social, possuidores de chaves que asseguravam o ingresso pelo seletivo portão da área cercada, norma que persiste até hoje (SEGAWA, 1996, p.44).

A partir do século XVII, toda a cidade importante da Europa construiu o seu passeio ajardinado: Berlim teve, em 1647, a Unter den Linden, ligando a cidade a 
um parque de caça no campo, o Tiergarten; Dublin teve o Beaux' Walk e o Gardiner's. Mall; Hamburgo o Jungfernstieg; Amsterdã aproveitou um charco transformando-o na Nieuwe Plantage em 1682; a partir de 1746, Bordeaux ganhou o Jardin Royal, assim como em Nancy o Pepinière Royal foi apropriado como passeio a partir de 1772; Viena fez em 1775 a Augarten e Munique, seu English Garden, em 1791. Madri contou a partir de 1745 com o Paseo del Prado, bem como o de Manzanares, Florida e o de las Delicias. Lisboa, após o grande terremoto de 1755, implantou seu Passeio Público a partir de 1764 (SEGAWA, 1996, p.44-45).

O primeiro passeio público criado na América antecede à maioria das realizações congêneres européias. Em 1592 foi iniciada a implantação da chamada Alameda, na Cidade do México. Ela era um jardim de perimetro aproximadamente quadrado, cercado, riscado por duas vias internas formando quatro áreas regulares. $\mathrm{O}$ passeio foi construído sobre terrenos encharcados, ganhos em aterros. Ele recebeu a configuração atual entre 1770 e 1776, quando foi transformado numa área retangular, acrescendo-se vias em diagonal, formando canteiros triangulares (SEGAWA, 1996, p.62-63). Em 1900 a Alameda ainda guardava as características do logradouro reformado no século XVIII: era um recinto de 513 x 259 metros, com o lado maior disposto na direção leste-oeste. Sete recantos circulares nos pontos de intersecção, 24 canteiros triangulares, caminhos paralelos e oblíquos destinados ao tráfego de carruagem formavam o pioneiro recinto de recreação (Marroqui, apud SEG̣AWA, 1996, p.63).

As capitais dos vice-reinos da Nova Espanha e Peru foram as cidades que receberam os primeiros passeios públicos americanos: a mencionada Alameda do México, em 1592 e Alameda de los Descalzos de Lima, em 1609. A segunda metade do século XVIII registrou a implantação de numerosos recintos ajardinados construídos para a população: Paseo de las Águas, a recuperação da Alameda de los Descalzos, Alameda de Acho e Alameda de las Cabezas, todas em Lima; o Paseo Bucareli, o Paseo de la Viga, o Bosque de Chapultepec e a recuperação da Alameda, no México; o Paseo Extramuros em Havana; a Alameda de Caracas; a Alameda Vieja e a Almeda Nueva em Bogotá; a Alameda de Buenos Aires; o Paseo de la 
Cañada e o Paseo de los Tajamares, ambos em Santiago do Chile (SEGAWA, 1996, p.66). Em 1783 seria criado o primeiro parque urbano brasileiro, o Passeio Público, no Rio de Janeiro (MACEDO e SAKATA, 2002, p.18)

No século XVIII, já se fazia distinção de dois conceitos de paisagismo: o jardim francês e o jardim inglês.

O jardim francês, de acordo com BERJMAN (200I) materializava-se em composições simétricas, em traçados grandiosos e regulares que abarcavam terrenos muito amplos sobre os quais o homem tratava de impor seu domínio sobre a natureza. O ponto culminante do jardim francês ocorreu no século XVII com a obra de Le Nôtre, que representa a aplicação da filosofia racional de Descartes, com seu mundo da ciência moderna, sua geometria analítica e sua ótica geométrica.

O estilo de Le Nôtre notabilizou-se por um geometrismo radical, com enormes eixos visuais que permitiam captar toda a composição de um só golpe de vista. Le Nôtre produziu verdadeiros cenários para a representação do drama fíctício da vida regulamentada pela corte, tendente a afirmar a concepção ideológica do estado absolutista: um modelo repetido em outras situações geográficas, que valorizava o conceito unitário do jardim, onde as partes apontavam para o todo (BERJMAN, 2001).

$\mathrm{O}$ jardim inglês, que tem seu apogeu no século XVIII, resultou da emergência de uma filosofia (o empirismo sensualista de Hume), de uma religião (o puritanismo que preconizava uma moral elevada negando o artificial), de uma literatura (a "garden literature"), de uma pintura (surgiu primeiro na tela do pintor e logo se modelou na realidade), de um teatro (com suas representações em cenografias vegetais), do melhoramento da ciência experimental e da imitação da natureza. $\mathrm{O}$ jardim inglês foi aquele da variedade, o do discurso não unitário, o dos contrastes, das continuas surpresas, dos recantos, da intimidade, do sentimento ou da sensibilidade, da ênfase no temporal (BERJMAN, 2001).

A fonte de inspiração do parque urbano, conforme KLIASS (1993, p.20), foi exatamente o modelo paisagístico dos jardins ingleses do século XVIII, que teve 
origem nas idéias românticas de volta à natureza aliadas à influência da cultura e artes orientais. Este modelo ganha uma linguagem informal de linhas curvas, modelado de relevo em colinas macias, rios e lagos, extensos gramados e grupos de árvores, tudo sugerindo, por meio de seu arranjo, as formas da natureza.

Destarte, o exemplo da Inglaterra foi seguido pelas principais cidades européias que aproveitaram o período de transformações urbanísticas pelo qual estavam passando. Onde foi possível, nos espaços não edificados, foram implantados parques públicos. Ou, então, adquiridos e reformados jardins privados para adaptálos às novas necessidades (FALCÓN, 2007, p.22).

No século XIX o ambiente urbano europeu e norte-americano era marcado pelo desconforto da grande maioria de seus habitantes, aglomerados em bairros desprovidos de infra-estrutura e submetidos a uma política de máximo aproveitamento do espaço, tanto público como privado. As cidades dominadas pela poluição gerada pela queima de carvão para o aquecimento e para a movimentação das máquinas, tornavam-se ambientes vistos como impróprios para a vida, ao contrário de como se interpretava a vida no campo (SARTI, 2002, p.144).

Uma visão do sentimento da época nos é trazido pelas palavras de Camillo Sitte:

"Em tempos imemoriais, nossos antepassados foram homens das florestas. Hoje somos homens dos edificios de apartamentos. Apenas isto bastaria para explicar a atração irresistível que a natureza exerce sobre o morador da metrópole moderna, sempre seduzido pelas áreas verdes, um verdadeiro refúgio contra o moinho de poeira deste oceano de moradias. Isto justifica que o indivíduo urbano, ávido pela natureza, manifeste um grande respeito por cada árvore, por cada pequeno gramado, ou cada vaso de flores à sua volta; de acordo com este sentimento popular, nem sequer um arbusto poderia ser sacrificado em nome das inevitáveis construções da cidade" (SITTE, 1992, p.165). 
Dessa.contraposição estética, filosófica e quase religiosa, desenvolvia-se a idéia de associação de melhores condições sanitárias com a presença de árvores e espaços onde elas pudessem ser plantadas e cultivadas. Plantar árvores passava a ser uma recomendação de valorização social e política. Associava-se a presença de árvores à purificação do ar e a criação de parques públicos ao combate de epidemias. Segundo esta concepção, árvores e parques tornariam o ar melhor e proporcionariam maior incidência de luz natural (SARTI, 2002, p.144).

O fenômeno da fotossíntese, descoberto no final do século XVIII, pelo qual as plantas verdes transformam dióxido de carbono em oxigênio, torna-se uma das grandes esperanças de melhoria da qualidade da atmosfera urbana, deteriorada pelos produtos do carvão. Esta expectativa é traduzida em todos os modelos que integram a vegetação na cidade a partir do século XIX (MAGALHÃES, 2001, p.75)

SITTE (1992, p.167), explicou, em pleno final do século XIX, que a importância do verde urbano não se deve resumir ao sentido estético, mas que ele também é fato indispensável por seus beneficios à saúde. A metrópole necessita de grandes superfícies não construídas e compostas por jardins, fontes e espelhos d'água, imprescindíveis para sua respiração, e por isso chamadas de seus pulmões.

Continua o mesmo autor afirmando não haver dúvidas quanto à importância de tais interrupções na grande massa de edifícios de apartamentos, através da manutenção de amplos espaços abertos, essenciais para a saúde, mas não menos importantes para o êxtase do espírito, que encontra repouso nestas paisagens naturais espalhadas em meio à cidade. Sem recorrer à natureza, a cidade seria um calabouço fétido (SITTE, 1992, p.167).

Em sintese, SARTI (2002, p.145) expressa que as necessidades decorrentes do caos urbano já consolidado criaram as condições polŕticas para que os parques fossem concebidos, projetados como objetos urbanos aos quais se associava uma função de salubridade, em primeiro plano, e uma decorrente função de controle social, subsidiariamente. 
Dentro desses princípios, foram sintetizadas na França, em um novo estilo e um novo uso, as duas correntes mencionadas (francesa e inglesa) por obra daquele que hoje é considerado pelos franceses como o inventor do jardim público: Adolphe Alphand. Este conseguiu interpretar o papel que lhe cabia na grande renovação urbanística impulsionada por Napoleão III em Paris, com a execução do plano do Barão Haussmann, que estabeleceu um sistema hierarquizado e ramificado em toda a capital, o qual the conferiu sua originalidade, incluindo bosques suburbanos, parques intramuros, "squares" e praças (BERJMAN, 2001).

Os primeiros espaços verdes criados a partir desse projeto constituíram-se nas pedras fundamentais da jardinagem pública impulsionada por razões de "higiene" e "moralidade": o Bois de Boulogne (1852) e o Bois de Vincennes (1860) como passeios de propriedade municipal (BERJMAN, 2001). Ambos haviam pertencido à coroa e foram seguidos por uma série de outros, entre os quais o Monceau, o Monsouris e o Buttes-Chaumont, este último recuperando uma jazida de calcário (KLIASS, 1993, p.22).

São dessa época e de perfil semelhante, entre outros, o Bois de la Chambre de Bruxelas (1864), la Tête d'Or de Lyon (1857-1882), o Parque de la Ciutadella de Barcelona (1872) (FALCÓN, 2007, p.22).

Berlim, em 1840, já tinha quatrocentos mil habitantes e apenas o Tiergarten, com duzentos e vinte hectares, como parque urbano. O diretor paisagístico do Reino da Prússia, Peter Joseph Lenné, havia reelaborado o seu desenho paisagístico entre 1832 e 1840 . Em 1843 foi criado o Invalidenpark, na mesma época que Gustav Meyer, assistente de Lenné, projetou o primeiro parque municipal berlinense, com quarenta e três hectares, o Friedrichshain. Entre 1869 e 1870 foi implantado o Humboldthain e nos anos de 1876 a 1888, o Treptower Park, quando já eram oitocentos mil os berlinenses e a atmosfera urbana havia se tornado quase insuportável (ALBUQUERQUE, 2006, p.160-162).

No mesmo periodo em que transcorria o processo europeu, de acordo com KLIASS (1983, p.22), desenvolvia-se nos Estados Unidos aquele que veio a ser 
chamado "movimento de parques americanos", cuja personalidade mais representativa foi o já mencionado Frederick Law Olmsted. Olmsted teve grande influência no desenho das cidades americanas com a inserção de parques na estrutura urbana através da utilização do seu potencial paisagístico. Exèmplos dessa intervenção são percebidos nas cidades de Nova York, Chicago e Boston, onde sua contribuição ultrapassou a dimensão do projeto do parque. Nesta cidade chegou a estabelecer um sistema de áreas verdes integradas por avenidas-parques, preservando vales e beira-rios, como no caso do parque linear ao longo do Charles River.

Sua obra mais notável talvez tenha sido o Central Park de Nova York, o primeiro parque com projeto paisagístico dos Estados Unidos. Os primeiros defensores da criação do parque, ricos comerciantes e proprietários de terras, admiravam os parques públicos de Londres e Paris e entendiam que Nova York deveria ter uma benfeitoria comparável para estabelecer sua reputação internacional. Um parque público ofereceria um atrativo para suas próprias famílias fazerem passeios de carruagem e ainda proveria à classe trabalhadora de Nova York uma alternativa saudável de diversão. Em 1853, após três anos de debate, a câmara municipal autorizou o executivo a adquirir cerca de trezentos e cinqüenta hectares no centro de Manhattan (BLACKMAR e ROSENZWEIG).

Tratava-se de um terreno irregular com atoleiros e ribanceiras, pontuado por afloramentos de rochas, entre a quinta e a oitava avenidas e entre as ruas 59 e 106, indesejáveis para o desenvolvimento privado. Entretanto, a criação do parque exigiu o despejo de mil e seiscentos pobres que lá residiam em favelas, inclusive criadores de porcos irlandeses e jardineiros alemães. A extensão de seus limites até a

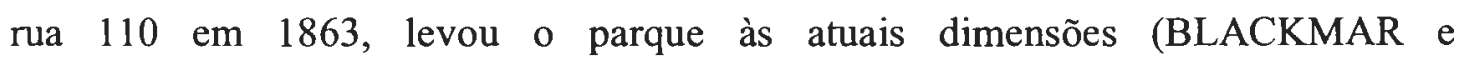
ROSENZWEIG).

Em 1857, a Comissão do Central Park escolheu o primeiro projeto paisagístico dos Estados Unidos, o “Greensward Plan”, apresentado por Frederick Law Olmsted e Calvert Vaux. Os paisagistas buscaram criar uma paisagem pastoral, na tradição romântica inglesa. Colinas suaves contrastavam com os efeitos pitorescos do Ramble e com o acabamento mais formal dos terrenos do Mall (Promenade) e do 
Bethesda Terrace. Com a finalidade de manter um sentimento de expansão ininterrupta, Olmsted e Vaux afundaram quatro ruas transversais, transferindo o tráfego que cruzaria a superfície do parque. Eles também revisaram o plano de circulação do parque, de modo a separar, o tráfego de carruagens, de pedestres e de cavaleiros. Vaux, assessorado por Jacob Wrey Mould, projetou mais de quarenta pontes para eliminar os cruzamentos entre as diversas rotas. $\mathrm{O}$ parque foi aberto à população no inverno de 1859 , quando milhares de usuários puderam patinar nos lagos construídos no lugar dos antigos charcos. Em 1865 o parque já estaria recebendo cerca de sete milhões de visitantes por ano. O jardim zoológico, por sua vez, instalou-se em 1871, rapidamente tornando-se a mais popular atração do parque (BLACKMAR e ROSENZWEIG).

$\mathrm{Na}$ década de 1970, vários cortes orçamentários resultaram num longo período de decadência na sua manutenção. Em 1980, a Central Park Conservancy, uma entidade privada, levou a cargo a restauração de algumas características do Greensward Plan, entre as quais, a Sheep Meadow, o Bethesda Terrace e o Belvedere Castle (projeto de Vaux e Mould). Entre 1980 e 1996, a direção da Central Park Conservancy e a administração do parque foram exercidas pela mesma pessoa. A partir de 1990, a organização privada contribuía com mais da metade do orçamento do parque e exercia substancial influência nas decisões a respeito de seu futuro (BLACKMAR e ROSENZWEIG).

O sucesso do Central Park repercutiu no desenvolvimento e estrutura de sistemas de parques em várias cidades americanas como Chicago, Boston, Albany, Buffalo, Rochester, San Francisco, Filadélfia, Detroit, Kansas City. Como também de novos bairros, exposições mundiais, áreas institucionais, campi universitários, áreas de preservação. Tanto que é devida a Olmsted a difusão das idéias de diversos conservacionistas para a implantação dos primeiros parques nacionais, em especial a do Parque Nacional de Yosemite (Magnoli, apud MARIANO, 1992, p.56; BARIDON).

A influência de Olmsted foi essencial para a criação de parques urbanos no Canadá. Como explica BAEYER, apesar da colonização inglesa, os parques não 
se incorporaram às cidades e vilas mais antigas canadenses. Como hoje são conhecidos, os parques surgiram na década de 1830, na forma de "cemitério rural": havia, então, uma tendência de transformar o cemitério em local de passeio e piqueniques em família. O cemitério de Mount Pleasant, em Toronto, era um bom exemplo.

O grande marco da história dos parques urbanos canadenses foi a criação do Parc du Mont Royal em Montreal, em 1874, exatamente por Olmsted. A filosofia de Olmsted em matéria de paisagismo de parques e espaços verdes no meio urbano influenciou fortemente o progresso dos parques canadenses, de modo que ela acabaria por nortear a lei sobre parques públicos da Colúmbia Britânica, de 1876; a de Ontário, de 1883 e a de Manitoba, de 1892 (BAEYER).

Esse modelo americano vigorou até o início do século $\mathrm{XX}$, inspirando praticamente todos os parques urbanos da época, inclusive aqueles criados na América do Sul, em sua, maioria por paisagistas europeus, a exemplo dos casos da Argentina, Uruguai e do Brasil (KLIASS, 1983, p.23).

Observa Mumford (apud CHOAY, 2003, p.286-287) que dada a densidade do habitat nas grandes cidades do século XIX, era natural que se sublinhasse a necessidade biológica dos espaços livres. $O$ parque era entendido não como uma parte integrante do meio urbano, mas como um local de refúgio cujo valor essencial vinha do contraste com a ruidosa e empoeirada colméia urbana. A maior parte das cidades, salvo no caso de terem recebido dos séculos passados a herança de alguns parques aristocráticos, algumas praças residenciais espaçosas ou certas áreas destinadas aos jogos, era tão pobre em espaços livres que estes passaram a ser considerados como se seu valor fosse diretamente proporcional à sua superfície, sem que se mostrasse muita preocupação com o acesso a eles, a freqüência de sua possível utilização ou sua incidência sobre a própria textura da vida urbana. As pessoas que não podiam suportar a ausência de jardins e parques mudavam-se, quando podiam, para os subúrbios espaçosos e repletos de verde; esta solução simplista teve como resultado que se congestionasse cada vez mais a cidade 
propriamente dita e que o campo fosse ficando cada vez mais longe do centro da urbe.

Deve-se dar crescente importância à função biológica dos espaços verdes, hoje que a cidade está cada vez mais ameaçada pela poluição de todos os tipos e que dentro do perímetro dos centros urbanos o ar formiga de substâncias cancerígenas. Mas não é tudo: aprendemos que os espaços livres também têm um papel social, freqüentemente negligenciado em benefício único de sua função higiênica (Mumford, apud CHOAY, 2003, p.287).

KLIASS (1983, p.23) informa que as transformações mais efetivas na concepção do parque urbano somente começaram a ocorrer após a I Guerra Mundial, época em que na Europa, especialmente na Alemanha, Áustria e Holanda, como também nos Estados Unidos do New Deal, iniciou-se um surto de modelos de urbanização baseados numa ideologia socializante, em que os parques ganham importância e uma linguagem que corresponde às artes em geral e particularmente da arquitetura, o estilo art-déco. Como exemplos podem ser citados os parques espanhóis: Montjuic, em Barcelona e Maria Luíza em Sevilha, de autoria do paisagista francês Jean-Claude Nicolas Forestier.

Nesse mesmo período, chamado "Reform Park" (1900-1930), nos Estados Unidos foi dada ênfase aos chamados "parques de vizinhança", um tipo de parque que priorizava o seu uso por crianças e trabalhadores, incorporado ao tecido urbano e que permitia uso noturno, uma questão ligada aos horários de trabalho (MARIANO, 1992, p.59). O parque típico de vizinhança era formado por um quarteirão quadrado ou dois e seu maior legado foi o "playground" (ALBUQUERQUE, 2006, p.92). Nos parques de maior porte foram incluidas piscinas públicas, cujo propósito principal era higiênico: exigia-se banho de chuveiro para ter acesso a elas (MARIANO, 1992, p.59-60).

Nessa concepção, a função do parque era eminentemente educativa. Daí o nome de "reform park": ele visava reformar os costumes. 
$\mathrm{Na}$ década de 1920, foram desenvolvidos na Alemanha os denominados "parques do povo" (Volksparks) que se caracterizaram pela ampla variedade de usos que se destinavam às mais diversas camadas sociais da.população. Neles havia espaços tanto para jogos e esportes como para o lazer contemplativo (ALBUQUERQUE, 2006, p.166).

Depois da II Guerra Mundial, as experiências das cidades novas da Inglaterra, da França e dos Estados Unidos, introduziram uma outra concepção urbanística, aplicada também às áreas verdes, com a incorporação dos conceitos da Carta de Atenas e do arquiteto-urbanista Le Corbusier (KLIASS, 1983, p.24).

Pela Carta de Atenas, elaborada no Congresso Internacional de Arquitetura Moderna de 1933 (CURY, 2000, p.40-42), todo o bairro residencial deveria compreender a superfície verde necessária à organização racional dos jogos e esportes das crianças dos adolescentes e dos adultos. Os volumes edificados devem ser intimamente amalgamados às superfícies verdes que os cercam. As zonas edificadas e as zonas plantadas devem ser distribuídas levando-se em consideração um tempo razoável para ir de umas às outras. A textura do tecido urbano deveria mudar; as aglomerações tenderiam a se tornar cidades verdes. Contrariamente ao que ocorre nas cidades-jardins, as superfícies verdes não devem ser compartimentadas em pequenos elementos de uso privado, mas consagradas ao desenvolvimento das diversas atividades comuns que formam o prolongamento da moradia (item 35). Os quarteirões insalubres devem ser demolidos e substituídos por superfícies verdes (item 36). As superfícies verdes, que se terão intimamente amalgamado aos volumes construídos e inseridos nos setores habitacionais, não terão por função única o embelezamento da cidade. Elas deverão ter um papel útil e as instalações de caráter coletivo ocuparão seus gramados: creches, jardins da infância, escolas, círculos juvenis, centros de entretenimento intelectual ou físico, salas de leitura ou de jogos, pistas de corrida ou piscinas ao ar livre. Elas deverão ser vistas como prolongamento da habitação (item 37). Os elementos naturais existentes devem ser considerados: rios, florestas, morros, montanhas, vales, lagos, mar, etc. Trata-se não só de preservar 
as belezas naturais ainda intactas, mas também reparar as agressões que algumas delas tenham sofrido (item 40 ).

Le Corbusier entende que a intensificação do trabalho moderno solicita com perigo cada vez maior nosso sistema nervoso. Daí exigir a calma, o ar salubre e não o viciado. Como considera as árvores o pulmão da cidade, entende que a cidade moderna, ao contrário do que normalmente ocorre, deve aumentar consideravelmente as superficies arborizadas e diminuir o caminho a percorrer, Cumpre então construir o centro da cidade verticalmente, mas os apartamentos residenciais não devem ser construídos em "ruas corredor", repletas de tumulto, poeira e dando para pátios escuros. $\mathrm{O}$ apartamento da cidade pode ser construído sem pátio e longe das ruas, com as janelas dando para parques extensos (LE CORBUSIER (2000, p.158).

Preconiza Le Corbusier o fim da rua-corredor para se criar a extensão da paisagem urbana. Extensão e não aquela única profundidade acanhada do corredor. Ao desenhar "loteamentos com reentrâncias", ele busca espalhar o horizonte longe à direita e longe à esquerda e, mediante voltas sobre o eixo longitudinal, compor arquiteturalmente: a linha outrora seca do corredor encerra agora prismas, acusa recuos ou saliências; a parede árida e enervante do corredor é substituída por volumes que se justapõem, se afastam, se aproximam, criando uma viva e monumental paisagem urbana. Essas reentrâncias devem ser aproveitadas para introduzir as árvores na cidade. Deixando as questões de higiene de lado, esteticamente, o encontro dos elementos geométricos das construções com os elementos pitorescos das vegetações constitui uma conjugação necessária e suficiente à paisagem urbana. Obtida essa riqueza de elementos plásticos, prismas nítidos dos edificios, volumes redondos das folhagens, linhas sinuosas das ramagens, que resta a fazer senão desenvolver tais vantagens (LE CORBUSIER, 2000, p.221-222).

O conceito urbanístico de Le Corbusier atinge seu apogeu na formulação da "cidade radiosa", na qual a urbe é um imenso parque em que os edificios estão dispostos em meio a gramados verdes e onde as "alegrias essenciais" nas moradias são céu, árvores, vista e sol. Cumpre ressaltar que a obra de Le Corbusier tem um significado fundamental para a arquitetura e urbanismo modernistas no Brasil, cujos 
representantes mais conhecidos são Oscar Niemeyer e Lúcio Costa, sendo a cidade de Brasília uma expressão concreta dos princípios da "cidade radiosa"(FRANCO, 2000, p.79).

Neste período, o paisagismo americano passa pela fase "Recreation Facility" (1930-1965), quando as administrações de parque abandonam sua idealização como mecanismos de reforma para ter na recreação seu elemento fundamental. A depressão americana e o pós-guerra levaram a um uso mais intenso de parques como opção de lazer (MARIANO, 1992, p.61-62).

O sistema de espaços livres é então concebido como abrangendo o todo da paisagem e do meio físico em interações escalares, desde os "pocket parks" até a totalidade da cidade. O desenho da paisagem trabalha com toda a amplitude de elementos naturais e materiais processados; nela estão incluídos terra, pedra, água, vegetação existente ou projetada e materiais construtivos como concreto, pedra, tijolo, madeira, metal e vidro (Eckbo, apud MARIANO, 1992, p.63).

A necessidade de espaços dedicados ao esporte e ao recreio de toda a gente e não só da classe dominante, foi também uma aquisição do modernismo, que continua longe de ser concretizada nas cidades atuais (MAGALHÃES, 2001, p.120).

Reis Filho (apud-MARCONDES, 1999, p.22), entretanto, tece críticas aos planos modernistas dos anos 1930. No seu entendimento eles apresentam a mesma rigidez e o mesmo caráter ideal dos planos maneiristas do século XVII. São frutos de um conjunto de princípios teóricos, captados através da razão. Seus autores aceitavam e valorizavam a verticalização e outras formas de centralização, aliadas, porém, à reconciliação do solo urbano com a natureza. Eram cidades-jardins verticais, onde as preocupações com a paisagem não se ligavam mais a razões de ordem romântica, anti-urbanas ou anti-industriais, mas a razões de ordem higiênica, como a insolação e a aeração dos edifícios.

Como ressalta MARCONDES (1999, p.22), esse ideário da "natureza artificializada" é reiterado no zoneamento funcionalista proposto pela Carta de Atenas, que domina o pensamento urbanístico até os anos sessenta do século XX, 
com vários desdobramentos nas intervenções urbanísticas nas cidades daquele século.

O atual urbanismo, no entender de FALCÓN (2007, p.22), tende à humanização das cidades e, neste contexto, o verde urbano joga um papel decisivo, já que consolida o acesso da cidadania à natureza como um direito social. Os parâmetros sobre os quais se estrutura o futuro dos espaços verdes são fundamentalmente ambientais e propõem um conceito de verde público baseado em critérios de uso e desfrute coletivo, ao mesmo tempo em que defendem uma conservação fundamentada na auto-suficiência e na reutilização dos recursos naturais.

MACEDO e SAKATA (2002, p.70) identificam as seguintes características nos parques contemporâneos:

(1) o programa funcional predominantemente ativo, embora alguns parques contemporâneos apresentem um programa exclusivamente contemplativo. O culto ao corpo ganha importância e, com ele, a disponibilidade e a diversificação de equipamentos esportivos;

(2) a tendência de preservação de ecossistemas antes considerados menos dignos de conservação, como charcos, manguezais $\mathrm{e}$ remanescentes de mata nativa, e ainda velhas pedreiras e aterros. Atividades relacionadas com educação ambiental passam a ser realizadas no espaço dos parques. A sinalização reforça a conscientização ecológica;

(3) o retorno aos antigos valores se funde às novas tecnologias e tudo pode ser experimentado, tudo é possivel. Elementos da arquitetura pós-moderna, como pérgulas, mirantes, pórticos, frontões e pontes, tornam-se cada vez mais comuns;

(4) os parques podem ser temáticos, destacando algum fato histórico ou homenageando alguma etnia importante; 
(5) o uso da vegetação segue a ideologia de preservação dos ecossistemas ou acompanha a tematização do espaço, compondo cenários variados;

(6) a água permanece como um importante elemento construtivo do espaço, na forma de lagos já existentes, nascentes, espelhos d'água, fontes, jorros e bicas.

FRANCO (2000, p.87-88) afirma que o pluralismo de tendências atuais no desenho dos espaços abertos, longe de um estado de caos, como podem querer alguns, prenuncia um novo momento no qual não faz mais sentido discutir as polaridades homem-natureza ou cidade-campo. O momento pós-moderno mostra que as relações sujeito e objeto e homem-natureza foram profundamente alteradas e transformadas pela concepção ecológica do oikos terrestre. Na verdade a relação entre ego e natureza foi sucedida pela de ambiente, que, por sua vastidão e complexidade, não admite nenhuma definição racional ou geométrica, Essa nova dimensão ambiental concretiza-se nas intrincadas relações e interações entre a realidade psicológica e a realidade física, num universo para o qual talvez o modelo mais próximo seja o holográfico.

Nos dizeres de FRANCO (2000, p.88), em termos histórico-formais, o homem só vem a perder o "medo da curva" após o surgimento da teoria revolucionária do matemático francês Benoit Mandelbrot, conhecida como "Fractais de Mandelbrot". A pesquisa de Mandelbrot sobre as formas irregulares da natureza o levou à criação de uma nova geometria, a geometria fractal, que, a partir da década de 1990, vem evidenciando perspectivas formais futuras totalmente novas e divorciadas do universo euclideano. Acredita a autora que a geometria dos fractais venha a se tornar nos próximos anos um instrumento básico para projetos ambientais.

A título de exemplo dessa nova vertente, pode-se mencionar o DuisburgNord

Park, em Duisburg na Alemanha (1990-2000), com cerca de 230 hectares de extensão, que utiliza a infra-estrutura industrial em desuso existente no seu sítio 
de implantação como esculturas e suporte para os novos programas que abriga, uma vez que preserva a história do lugar (NUEVAS TENDENCIAS EM PARQUES URBANOS, 2006). Igualmente, o Jardin Atlantique, em Paris, com área de 57 mil metros quadrados, instalado na estação ferroviária de Montparnasse e suspenso sobre lajes de cobertura situadas 64 metros acima dos trilhos. Possui cento e trinta e sete orifícios no seu solo para clareamento e areação da estação. Ele compõe um espaço multifuncional com estação, estacionamento, escritórios, museus e espaços verdes (LES ESPACES VERTS, p.03-04).

Entre os novos tipos de parque, resultantes da crescente sensibilização em torno das questões ambientais e da constatação de que os habitats naturais situados no exterior dos centros urbanos diminuem em um ritmo assustador, Doug Ross descreve o denominado parque selvagem urbano. Um parque deste tipo é administrado de modo a manter um nível de biodiversidade elevada. A poda da relva é reduzida ao mínimo necessário. As folhas que caem e as árvores mortas são deixadas em seu lugar. De fato, o parque selvagem representa uma parte do habitat deixada em estado natural no interior da cidade (ROSS).

No Japão, sobretudo em Tóquio, a partir da década de 1970, foram projetados os primeiros rios-parque aquafilicos (shinsui) no distrito de Edogawa, que a principio se constituiram em parques lineares sobre córregos com o intuito de familiarizar as crianças com a presença da água. Antigos córregos foram destamponados e/ou renaturados para que se pudesse restabelecer neles a fauna $\mathrm{e}$ flora originais. Nas primeiras experiências, entretanto, só se pretendeu a despoluição dos rios e um tratamento paisagístico adequado. Na década seguinte, foi introduzido para os rios um desenho ecológico, com uma nova ótica sobre o ambiente natural das vias fluviais, preocupada com as determinantes ecológicas do desenho paisagístico. Como exemplo, temos na cidade de Yokohama, os rios Itachigawa e Izumigawa. Esta tendência tem caracterizado a recente restauração de rios urbanos no Japão (OZEKI e ESTEVAM, 2006, p.91).

Outra tendência recente dos parques urbanos é a representada pelos jardins comunitários (community gardens) dos Estados Unidos. Só no Bronx, em 
Nova York, foram criados 34 novos jardins em 1995. De Oakland a Atlanta, moradores urbanos de todas as camadas da sociedade estão reivindicando lotes vagos, plantando jardins e desafiando estereótipos urbanos negativos. Ao mudar a paisagem urbana, estes jardineiros voluntários estão também reanimando a comunidade e redescobrindo a importância da natureza para sustentar o corpo e a alma (TAYLOR).

Áreas urbanas e projetos comunitários de jardinagem ocorrem em muitas cidades, desde os anos 1960 e 1970. Em Houston, a horticultura urbana foi primeiramente promovida como uma estratégia contra fome. Um grupo local sem fins lucrativos, The Park People ("O Pessoal do Parque"), uniu criativamente quarenta hortas locais a balcões de comida e cozinhas populares, garantindo que os sem-teto e pessoas carentes recebessem alimentos nutritivos. Agora "O Pessoal do Parque" está criando uma rede mais ampla de pomares e canteiros de ervas por toda a cidade (TAYLOR).

Em New Orleans, com mais de dez mil lotes vagos, jardins comunitários são um raro sinal de revitalização urbana. A cidade tem o índice de homicídios mais elevado do país e mais de trinta por cento dos residentes vivem abaixo do nível da pobreza. No entanto, durante a década de 1980, mais de doze mil cidadãos voluntários ajudaram a regar, capinar, limpar, cortar grama e plantar mil e duzentos hectares de espaço verde (TAYLOR).

Em Los Angeles, imediatamente após os motins de 1992, foi constatado que mesmo nos bairros mais atingidos, onde a maioria das construções foi queimada e quase todo o resto destruído, os desordeiros haviam respeitado os jardins. Enquanto nada mais foi poupado, os jardins serviram como um campo comum, quase sagrado, no meio do conflito mortífero (TAYLOR).

O Fundo de Áreas Naturais de Boston está ajudando setecentas famílias de baixa renda a preservar hortas nas áreas infestadas por crimes. Em 1996, essas hortas geraram mais de um milhão de dólares em produtos agrícolas, assegurando alimentação saudável para muitas famílias carentes. Em 1998, o fundo ajudou a 
comunidade hispânica de Boston a criar pelo menos três novas hortas e um parque comunitário (TAYLOR).

Programas de implantação de áreas verdes também têm um impacto acentuado nos índices de criminalidade. De acordo com o Conselho Nacional de Prevenção ao Crime, os policiais de Filadélfía observaram uma relação direta entre os lotes vagos, prédios abandonados e altos índices de criminalidade. A polícia do $26^{\circ}$ distrito de Filadélfia trabalhou junto com o grupo sem fins lucrativos Philadelphia Green para ajudar os cidadãos locais a limpar lotes vagos e implantar jardins. Hoje o indice de criminalidade nessa área diminuiu acentuadamente e as crianças que ajudaram a implantar os jardins alguns anos atrás, são adolescentes que cuidam da manutenção do espaço verde (TAYLOR).

A participação ativa dos residentes locais aproxima as pessoas e promove recreação e responsabilidade mútua pelo lugar. Esses esforços cooperativos para melhorar os espaços abertos freqüentemente aumentam a cooperação em outros aspectos da vida na vizinhança. Grupos comunitários, que inicialmente trabalham juntos para criar ou proteger um jardim comunitário, continuam a enfrentar questões adicionais, inclusive problemas de criminalidade, desenvolvimento juvenil, educação, habitação e emprego (Francis, apud TAYLOR).

$\mathrm{Na}$ esteira dos referidos "community gardens" americanos, os países europeus vêm desenvolvendo os chamados "jardins partilhados", notadamente na Alemanha e na França. A experiência atual destes parques traduz a emergência de novos espaços verdes que encarnam uma vontade de ruptura, não somente com a concepção da gestão dominante dos parques, mas também com a evolução atual da cidade e da urbanização, marcada pelo desenvolvimento da fragmentação urbana e pela privatização dos espaços públicos. As virtudes do coletivo, a preocupação com o meio ambiente, a recusa da densificação urbana, fruto da especulação imobiliária, constituem os valores fundamentais dos jardins partilhados (LES ESPACES VERTS, p.05). 
Somente em Paris existem cerca de trinta jardins partilhados e muitos outros estão ainda em projeto, ocupando espaços deixados provisoriamente vagos, terrenos baldios à espera de projetos mais importantes. Estes interstícios do espaço urbano, superficies sem valor, da ordem de algumas centenas de metros quadrados, são criados e geridos por associações reconhecidas pela municipalidade. Às atividades de jardinagem, juntam-se outras práticas: culturais (exposições, projeções de filmes), pedagógicas e sociais (refeições de bairro, feiras de compra e venda de usados), que dão ao jardim sua dupla significação, ambiental e social. Freqüentemente, alguns vínculos são estabelecidos com escolas, creches, hospitais de bairro, para se associarem ao seu projeto e realização (IDEM).

O jardim partilhado não esta isento de críticas pelas suas ambigüidades e contradições. Afinal, um jardim que se propõe "ecológico", destinado a favorecer a biodiversidade, componente essencial do desenvolvimento sustentável, é por definição não durável (cessão de uso por até cinco anos). Com vocação essencialmente voltada à jardinagem, muitas vezes é composto por espécies das mais banais, que em quase nada incrementam a biodiversidade (IDEM).

Destinado também a criar um espaço social, o jardim partilhado aparece, às vezes, como espaço de conflito potencial. A impossibilidade de um espaço tão limitado satisfazer todas as demandas de uma vizinhança pode contribuir para opor os detentores das áreas e os demais moradores. Embora o jardim seja teoricamente aberto a todos, ele é freqüentemente administrado por um pequeno grupo (LES ESPACES VERTS, p.06).

Os jardins partilhados, ao ocuparem terrenos sem valor econômico, acabam por se tornar elementos de valorização do espaço urbano, o que facilita o sucesso de operações especulativas. Ele participa como aliado de uma política pública que visa acrescentar atratividade à metrópole, dando-lhe uma imagem de modernidade que também contribui para pressionar os preços dos imóveis (IDEM).

Enfim, surge de fato uma contradição entre a pretensa autonomia da sociedade civil na gestão desses parques e a realidade, na medida em que os terrenos 
onde eles são implantados freqüentemente pertencem às municipalidades; são elas que acabam sendo as principais concessionárias do direito de uso às associações. Isto implica numa subordinação de fato às prioridades políticas das administrações municipais. Prova disto transparece na vontade atual da administração municipal parisiense de implantar novos jardins partilhados no interior de parques sob sua gestão direta, de modo descarregar suas obrigações sobre os ombros das associações (IDEM).

Em suma, para seus críticos, o jardim partilhado é mais uma conseqüência do que uma solução para a crise urbana, marcada por uma crescente segregação sócio-espacial (IDEM).

Em especial, observa-se que os parques urbanos vêm exercendo um papel central como instrumento de valorização fundiária em operações recentes de revitalização, ou requalificação urbana, de bairros residenciais e áreas industriais e comerciais decadentes em Paris (SERPA, 2007, p.41). O paisagista Gilles Clément, um dos criadores do Parque André-Citroën, inclusive manifestou sua estranheza diante do discurso contraditório da prefeitura de Paris. Porque de um lado ela cria novos parques, que são realmente interessantes em termos de concepção, mas, por outro lado, expulsa para a periferia os antigos habitantes dos bairros onde esses parques são implantados. Essas pessoas não possuem renda para continuar em Paris, por isso são rejeitados pela cidade. $O$ discurso oficial defende a idéia de que o parque dará aos habitantes da cidade uma vida mais agradável, mas, na verdade, esses parques são, em grande parte, reservados a um tipo específico de público, que não inclui os menos favorecidos, em termos de renda e formação (apud SERPA, 2007, p.41-42).

SERPA (2007, p.42), analisando comparativamente os parques urbanos mais recentes em Paris e Salvador, conclui que estes são elementos de valorização do espaço urbano que contribuem para um processo de substituição de população nas áreas requalificadas. Eles tornam-se álibis para justificar as grandes transformações físicas e sociais dos bairros afetados pelas operações de requalificação urbana. Álibis, porque os parques urbanos sempre representam e expressam valores éticos e 
estéticos que ultrapassam largamente seus limites espaciais. Qualquer que seja a época, esses valores estão presentes no discurso oficial e nas políticas públicas aplicadas às cidades: higienismo, pacifismo, beleza estética. Essa reunião de valores reforça uma metáfora, ainda hoje pertinente, de que o parque urbano é um instrumento de integração social e espacial das cidades. Trata-se, no entender do mesmo autor, de um discurso sobretudo promocional, veiculado pelos poderes públicos, mas também pelos promotores e incorporadores imobiliários. Os novos parques parecem ter sido concebidos como elementos centrais de operações urbanas para provocar voluntariamente uma implacável mudança da população, funcionando como aceleradores das mudanças no perfil social dos bairros e cidades "requalificados".

Em sentido assemelhado, CASTELNOU (2006, p.69 e 71) critica a "espetacularização" e a "mercantilização" dos parques curitibanos, utilizados pelos governantes como cenários publicitários para vender a imagem da cidade como "capital ecológica", onde não existem mais contradições, desequilíbrios ou problemas sociais, de modo a mascarar a realidade.

\subsubsection{Parques urbanos paulistanos e sua história}

O primeiro parque de São Paulo foi o Parque da Luz. Nascido de um Ofício Régio em 1798, mas só inaugurado em 1825, o Horto Botânico da Luz desempenhou num primeiro momento sua função botânica original e também a de espaço de recreio. A função botânica não chegou a ser significativa, tanto que em 1838, a Assembléia Provincial alterou seu nome para Jardim Público (BARTALINI, 1999, p.14).

No decorrer do século XIX ele foi inteiramente adaptado à função de parque urbano, tornando-se ponto de encontro dos barões do café e seus associados. 
Essa elite começa a ocupar, a partir de 1870, os recém-inaugurados bairros dos Campos Elísios e Santa Ifigênia, redutos das famílias mais ricas de São Paulo por todo o restante do século e um tanto mais (MACEDO e SAKATA, 2002, p.23).

BARTALINI (1999, p.15) observa que o Parque da Luz foi uma iniciativa isolada, não lastreada nos hábitos de lazer do paulistano comum, haja vista os constantes relatos de abandono e mau uso daquele espaço. Tais fatos fornecem provas do descompasso entre o que se oferecia como espaço de lazer e o que realmente se praticava.

Efetivamente, apenas na administração provincial de João Teodoro (18721875), foi implantado um novo parque em São Paulo: a Ilha dos Amores. Situava-se numa pequena ilha, resultante da retificação do rio Tamanduateí, rente à rua Vinte e Cinco de Março, com aproximadamente trezentos metros de comprimento e largura média em torno de sessenta metros. Ali, segundo testemunhos da época, podia-se descansar à sombra das árvores, ouvir música tocada por bandas e comer bem num restaurante denominado "Chalé da Ilha". O braço menor do rio, que era cruzado por uma ponte em arco, servia de piscina pública antes de desaguar adiante, no mesmo Tamanduateí. No entanto, ainda em meados da década de 1890, o espaço estava totalmente abandonado (BARTALINI, 1999, p.36-37). A Ilha dos Amores desapareceria tragada por nova retificação do rio iniciada em 1896 e terminada em 1915 (MOURA, 1980, p.179-180).

Durante o século XIX, salvo as citadas exceções do Parque da Luz e da Ilha dos Amores, o ajardinamento concentrava-se nas antigas praças de origem colonial. Como explanam ROBBA e MACEDO (2002, p.28-29), o surgimento da praça ajardinada é um marco na história dos espaços livres urbanos brasileiros, pois altera a função da praça na cidade. $\mathrm{O}$ mercado foi transferido para edificações destinadas a atividades comerciais; as demonstrações militares de poder não acontecem mais nos largos e nos campos, deslocando-se para as avenidas. A praçajardim deixa de ser (como eram no período colonial o largo, o terreiro e o adro da igreja), o palco da vida mundana e religiosa, civil e militar da cidade. A praça agora é 
um belo cenário ajardinado destinado ás atividades de recreação e voltado para o lazer contemplativo, a convivência da população e o passeio.

Destarte, foram ajardinados e cercados o largo Municipal em 1879, o largo do Palácio em 1886 e o largo de São Bento em 1887 (BARTALINI, 1999, p.28). O largo Municipal, antigo largo de São Gonçalo e largo da Cadeia, é a atual praça João Mendes (PORTO, 1996, p.102-103). O largo do Palácio é o atual pátio do Colégio (IDEM, p.50).

Em 1893, quando todas as áreas verdes da cidade passaram da administração do Estado para a do Município, existiam apenas sete espaços ajardinados. Além dos Parques da Luz e Ilha dos Amores, existiam os largos Municipal, de São Bento, da Memória e os taludes do Carmo. Segundo o relatório do intendente do mesmo ano, os taludes do Carmo e o Parque da Luz apresentavam problemas de conservação, enquanto os jardins dos largos Municipal, São Bento e Palácio estavam regulamente cuidados. A Ilha dos Amores já havia desaparecido completamente (BARTALINI, 1999, p.28-29). O largo da Memória era então apenas um terreno arborizado e fechado por muro (BRUNO, 1981, p.138). Os taludes do Carmo correspondiam ao adro da Igreja do Convento do Carmo e da Ordem Terceira do Carmo, demolido para construção da avenida Rangel Pestana (SESSO JÚNIOR., 1986, p.298). De todas essas áreas verdes, somente restaria o Parque da Luz, que será melhor analisado no próximo capítulo.

Na gestão do prefeito Antonio Prado (1899-1910) houve alguns avanços no campo paisagístico: remodelação do Parque da Luz, arborização da avenida Tiradentes, ajardinamento da praça da República (1902-1905), novo arranjo do largo do Arouche, acerto das margens do rio Tamanduateí, na várzea do Carmo, com plantio de grama e árvores. Entre 1907 e 1909, foi implantada a versão inicial do Parque da Independência, um jardim francês defronte o Museu Paulista, projetado por Arsène Puttemans. Antonio Prado também deu início a um ambicioso programa de arborização de ruas (CAMPOS, 2002, p.82-83). Pela mesma época, a partir de 1905 , por iniciativa do seu diretor, Rodolfo von Ihering, iniciou-se a implantação de 
um horto botânico na parte de trás do prédio do museu (GUARALDO, 2002, p.87), do qual restou o atual bosque ali situado.

Na São Paulo do inicio do século XX, poucas eram as áreas verdes de algum porte de domínio publico: o Parque da Luz, herdado dos tempos imperiais; o Horto Florestal, na Serra da Cantareira, implantado pelo governo estadual no inicio da República junto aos mananciais de abastecimento de água; e a praça da República, antigo campo de touradas remodelado por Antônio Prado . As maiores áreas de lazer eram detidas por empresas particulares, que ofereciam acesso ao verde e outras diversões como forma de atrair consumidores, como era o caso do Parque Antártica na Água Branca, dedicado ao consumo de cerveja e o do Bosque da Saúde, também pertencente à Companhia Antártica Paulista. Outros parques privados eram elementos de atração para loteamentos adjacentes, caso do Jardim da Aclimação. Outras matas particulares de acesso público eram o Parque Jabaquara, o Bosque de Santana, a Granja Julieta, etc. (CAMPOS, 2002, p.302).

Entre os objetivos das empresas que detinham tais glebas estavam sua eventual exploração imobiliária, na medida em que o violento processo de crescimento urbano traria fatalmente excepcional valorização para qualquer terreno mantido no raio dessa expansão. No entanto, a presença de tais áreas parecia minimizar o problema de carência de parques públicos em São Paulo (CAMPOS, 2002, p.302).

Em 1892 foi fundado o Jardim da Aclimação, como parque recreativo, primeiro zoológico paulistano e também primeiro posto zootécnico do Brasil. Foi uma iniciativa particular de Carlos Botelho (DOREA, 1982, p.46). Na década de 1930 a família Botelho iniciou seu loteamento. Em 1939 a prefeitura desapropriaria a área remanescente (DOREA, 1982, p.99-100), que resultou no atual Parque da Aclimação.

Em 1900 foi inaugurado o Parque Antártica, num terreno de aproximadamente dezoito hectares de propriedade da Companhia Antártica Paulista, na Água Branca. Era um parque projetado com ruas de traçado retilíneo e árvores 
plantadas com o fim específico de proporcionar sombra aos visitantes. Era servido por uma linha de bondes elétricos com tarifas reduzidas, de modo a estimular a freqüência do lugar (BARTALINI, 1999, p.42). Lá existiram pelo menos dois baresrestaurantes, locais sombreados para piquenique, cancha de bocha, rinque para patinação, carrinhos de passeio para crianças (puxados por bodes), roda gigante, cavalinhos de pau, teatro de marionetes, competições de corrida a pé e campo de futebol (Americano, apud BARTALINI, 1999, p.42). Este parque teve vida curta, pois em 1916 foi alugado pelo Palestra Itália para realização de jogos de futebol, sendo posteriormente adquirido pelo mesmo clube em 1920 (Pontes, apud BARTALINI, 1999, p.42).

A Companhia Antártica Paulista também era detentora do Bosque da Saúde, área de aproximadamente cinco hectares distante cerca de seis quilômetros e meio do centro da cidade, por linha servida por bondes elétricos (BARTALINI, 1999 , p.42). Segundo.MASAROLO (1971, p.90), este parque era localizado entre as atuais avenidas Bosque da Saúde e Ricardo Jafet, e formado de uma grande extensão de mata atlântica, com caminhos em várias direções em seu interior, onde as crianças subiam nas árvores e balançavam nos cipós. Nas clareiras encontravam-se ranchos toscos feitos com paus e cipós, cobertos com folhas de coqueiro e nas baixadas encontravam-se pequenos córregos de água fresca. Na parada do bonde, com balão de volta, havia bar e cavalinhos de pau girando dentro de um grande galpão que faziam a alegria dos visitantes. Era muito freqüentado por grupos que organizavam piqueniques e por escolas que levavam seus alunos a passeio. Inaugurado nom início do século XX, segundo Pontes (apud BARTALINI, 1999, p.42), já em 1925, com a abertura do loteamento do Bosque da Saúde, os paulistanos deixaram de contar com esta área verde de recreação. Ainda segundo MASAROLO (1971, p.90), restaria por uns anos apenas um bar e um salão de bailes muito freqüentado por alemães.

Em 1920, quando os proprietários do Bosque da Saúde preparavam-se para loteá-lo, os vereadores Anhaia Melo e Luciano Gualberto, que era médico, apresentaram projeto de lei declarando de utilidade pública as matas do Bosque da Saúde, propriedade de Mário Otoni de Resende, com o objetivo de transformá-las 
em área verde pública, considerando que o local já seria de fato um logradouro público, com belíssima mata, visitada por uma grande parte da população paulistana, especialmente aos domingos (CAMPOS, 2002, p.309).

O projeto foi aprovado, mas a desapropriação foi orçada em 2.500 contos de réis, inviabilizando a iniciativa, e o Bosque da Saúde foi infelizmente loteado e destruído a partir de 1925 (poucos anos antes, o terreno havia sido vendido a Mário Otoni de Resende por apenas 400 contos). A imprensa chegou a acusar Luciano Gualberto de pretender locupletar-se por meio dessa tentativa de desapropriação, tentando desmoralizar a louvável intenção do legislativo (CAMPOS, 2002, p.309).

A Granja Julieta, chamada originalmente Chácara dos Belgas, em Santo Amaro, foi adquirida em 1918 pelo açoriano Manuel Justino de Almeida, rico empresário que não mediu esforços pra transformar a chácara numa bela propriedade. Para tanto reformou a residência ampliando-a e embelezou as suas imediações com vegetação exótica. A suntuosa sede existe ainda hoje, como Casa de Repouso Granja Julieta. O açoriano ainda mandou construir um zoológico, na época considerado o maior de propriedade particular da América Latina. Havia onças, macacos, lobos, pavões, ursos, zebras, antílopes, antas e muitos outros animais que faziam a alegria dos visitantes. Com a morte de Almeida em 1940, a área foi vendida a um grupo empresarial que loteou a região a partir dos anos 1950 (PONCIANO, 2001, p.86-87).

Como se pode observar, estes parques particulares somente existiram enquanto correspondiam aos desejos de seus donos. Muitas vezes eram mantidos para propiciar a valorização econômica ou servir de propaganda para a área em que se situavam. Posteriormente eram totalmente loteados, visando a obtenção pura e simples de lucros para seus proprietários. Somente sobreviveram os atuais Parques da Aclimação e Tenente Siqueira Campos (Trianon), eis que adquiridos pela municipalidade, os quais serão objetos de análise mais detida no próximo capítulo.

À luz das prescrições do moderno urbanismo em que os parques eram essenciais à salubridade das grandes aglomerações, a prefeitura priorizou a abertura 
de praças e espaços livres nos loteamentos mais consolidados, junto à área central (CAMPOS. 2002, p.302). Para tanto a mata da avenida Paulista (Parque Villon, depois Parque do Trianon, atual Parque Tenente Siqueira Campos) foi desapropriada em 1911 (BARTALINI, 1999, p.52); os terrenos da praça Higienópolis (hoje Parque Buenos Aires), em Higienópolis, foram desapropriados em 1912. A praça foi inaugurada em 1913, com jardins projetados pelo paisagista francês Bouvard (HOMEM, 1980, p.72).

Para arejar e decorar o centro da cidade, os planos da prefeitura previam, além da ampliação da praça da Sé e da abertura da praça do Patriarca (elementos mais ligados à composição viária e arquitetônica ), os parques do Anhangabaú e da várzea do Carmo, ladeando a colina central. Além do propósito higienista, concorriam para a amenização paisagista e para a valorização pitoresca de edifícios que representavam os poderes sediados na capital (CAMPOS, 2002, p.304).

Foi então formado um sistema de parques em São Paulo, um anel verdejante em volta do velho centro histórico, que ocuparia as várzeas e alagadiços que circundavam essa área, então em processo de requalificação. Esse sistema, formalizado por Joseph Antoine Bouvard em 1911, dotou a cidade dos seus mais importantes parques da primeira metade do século XX: o Parque Dom Pedro II e o Parque do Anhangabaú, este último uma singela e bem elaborada via parque. Ambos foram desenhados e configurados por E. F. Couchet, segundo a escola anglo-francesa de paisagismo, já adotada décadas antes por Glaziou no Rio de Janeiro e em Buenos Aires por Carlos Thais (MACEDO e SAKATA, 2002, p.27).

O Parque Dom Pedro II foi o resultado de um bem sucedido projeto de saneamento e urbanização que transformou o antigo alagadiço da várzea do Carmo, havia décadas já utilizado para o lazer pela população, resultando em grande valorização para a região em termos imobiliários (MACEDO e SAKATA, 2002, p.27). Com 450 mil metros quadrados de área total, este parque seria inaugurado em 1922 (CAMPOS, 2002, p.307). 
Mesmo mal cuidado, o Parque Dom Pedro II sobreviveu até a década de 1970, quando sucumbiu diante das prioridades concedidas ao sistema viário. Cortado por avenidas e viadutos, com grandes áreas perdidas para um terminal de ônibus e o "fura-fila", abrigo de indigentes e depósitos de entulho, cortado pelo poluído e tamponado rio Tamanduateí, este parque é hoje pouco mais que um extenso terreno baldio cruzado por vias de tráfego intenso de veículos. Nas palavras de MACEDO e SAKATA (2002,p.55), o Parque Dom Pedro II degradou-se a ponto de tornar desagradável qualquer percurso a pé.

O Parque do Anhangabaú resultou de um elaborado projeto que conectou o novo Teatro Municipal com os palacetes Prates erguidos na rua Líbero Badaró. A área antes dominada por fundos de quintal, transformou-se em elegante moldura para os novos palácios da "capital do café" (MACEDO e SAKATA, 2002, p.27-28).

Sua devastação viria a ocorrer na década de 1940, quando o prestigioso prefeito Prestes Maia transformou-o numa avenida. Para Prestes Maia as áreas verdes deveriam servir de cenário para emoldurar a passagem de veículos, numa espécie de "neobarroco"; tanto que ele considerava o Parque do Anhangabaú, que destruiu, um jardim "antiquado" e igualmente foi responsável pela reformulação do largo do Arouche e da praça João Mendes, logradouros transformados em pequenas ilhas de vegetação cercadas de carros por todos os lados. Esse também seria o destino da praça da República, considerada por Prestes Maia de "aspecto provinciano que aberra no local e das necessidades modernas de circulação" (MAIA, 1945, p.12-13). Felizmente a praça "provinciana" conseguiu sobreviver à sanha destruidora de um modelo de cidade já naquela época voltado essencialmente à circulação de veículos. Modelo este que é o cúmulo do elitismo, bastando lembrar o número ínfimo de carros na São Paulo da época, todos importados e depositados em mãos abonadas. Enquanto isso a população humilde sofria num sistema de transporte público péssimo, sem qualquer esperança de ver ao menos a chegada do metrô. Data vênia, isto sim é uma aberração.

Na década de 1980, um concurso público realizado pela municipalidade premiaria o projeto dos arquitetos e paisagistas Jorge Wilheim, Jamil José Kfouri e 
Rosa Grena Kliass. Nesse projeto o tráfego de veículos foi transferido para túneis que passam sob uma grande praça de aproximadamente 60 mil metros quadrados, onde foi restabelecida a conexão peatonal entre os dois lados do centro da cidade, sem pretender trazer de volta o sítio original, mas criar um espaço urbano que enfatizasse as características do vale (ROBBA e MACEDO, 2002, p.134).

Em 1922, o parque defronte do Museu Paulista foi reciclado e complementado por Reinaldo Dierberger para o centenário da independência. Foi talvez o primeiro parque temático-comemorativo do país, uma vez que objetivava a valorização do sítio histórico da independência. Foi desenhado de modo a formalizar um eixo monumental, que centrado no frontão do museu, fazia a sua conexão com o Monumento da Independência e deste último, com a avenida D. Pedro I, que liga a área ao centro da cidade. Na parte frontal do palácio foi concebida uma terrazza magnífica, recortada geometricamente por canteiros floridos e fontes, emoldurados por árvores frondosas e dois grandes terraços laterais (MACEDO e SAKATA, 2002, p.29-30).

Para configurar outro grande parque municipal a prefeitura havia adquirido em 1912 a chácara da Floresta, na margem esquerda do rio Tietê .Contudo era um terreno inundável, não sendo possível sua utilização sem que o rio fosse canalizado, perspectiva ainda distante naquele momento. Mesmo assim, quando da estada do paisagista inglês Barry Parker em São Paulo, de 1917 a 1919, este foi contratado para elaborar um projeto de aproveitamento para a Floresta. Parker não se contentou em projetar parques isolados e imaginou um "cinturão aberto de parques" em torno da cidade, seguindo as várzeas do Tietê e Pinheiros, limitando o crescimento urbano e valorizando os loteamentos contíguos (Andrade, apud CAMPOS, 2002, p.307-308).

Os sucessivos planos para a canalização do Tietê incorporaram as áreas municipais da Floresta e da Coroa (área alagada entre a Ponte Grande e a Vila Guilherme) como elementos-chave. Em 1922, Fonseca Rodrigues imaginou duas grandes bacias para esportes náuticos, rodeadas por áreas residenciais; em I925, Saturnino de Brito concebeu dois lagos-reservatórios que permitiriam controlar a 
vazão do rio e evitar inundações; entre 1926 e 1928, Ulhoa Cintra projetou um lago rodeado por uma faixa verde na Coroa, formando um parque náutico, mais um parque esportivo a jusante, entre a Ponte Grande e a Casa Verde. Os parques de Cintra seriam redesenhados por Prestes Maia no Plano de Avenidas de 1930 (CAMPOS, 2002, p.308).

Não obstante, os terrenos municipais à margem do Tietê começaram a ser concedidos a clubes particulares. O Clube da Floresta assumiu o nome da antiga chácara; em seguida, vieram os clubes Espéria, Tietê, etc. O maior espaço restante, já ocupado por um aeródromo, seria apropriado pela Aeronáutica para o seu Campo de Marte. A partir de 1940, no momento em que a canalização do Tietê possibilitou o aproveitamento dessas glebas, a maior parte já estava ocupada. Outros remanescentes dos terrenos municipais à margem do Tietê seriam ocupados pelo Parque Anhembi, pelo Terminal Rodoviário do Tietê e por dois centros de compras, estes últimos instalados em terrenos que foram objeto de disputa judicial com a prefeitura (CAMPOS, 2002, p.309).

Em 1924, a Câmara Municipal propôs a aquisição de um trecho de cobertura vegetal que, embora distante do perímetro urbano, possuía especial importância histórica, paisagística e simbólica: o Pico do Jaraguá e as matas circundantes. Propunha-se que a prefeitura adquirisse duzentos alqueires no Jaraguá, como uma reserva verde na periferia. Seria resguardado, junto com um dos últimos trechos de mata nativa do Município, um ponto relevante para a memória local, ligado à tradição bandeirante. A moção foi aprovada em 1925 e o sítio foi declarado de utilidade pública. Porém a avaliação judicial da área resultou no preço de mil e duzentos contos, embora a gleba tivesse sido vendida pouco antes a um particular por apenas seiscentos e cinqüenta contos. $O$ custo foi considerado inviável pela prefeitura que solicitou a revogação da lei (SÃO PAULO, 1925, p.874-878). Apenas em 1940 o sítio passaria a ser de domínio público, porém do Estado de São Paulo. Este transformaria a área no Parque Estadual do Jaraguá, criado pelo Decreto Estadual 38.391 de 03/05/1961 (PICO DO JARAGUÁ), uma unidade de conservação dentro da tipologia do SNUC. 
Em 1926, quando se iniciava a administração do Prefeito Pires do Rio, a prefeitura decidiu-se pela criação de um grande parque nos terrenos municipais do Ibirapuera, antes pensado para a chácara da Floresta, Jaraguá e outros lugares (CAMPOS, 2002, p.312).

Essa decisão amparou-se em uma visão de futuro bastante previdente. São Paulo, então com cerca de 700 mil habitantes, contava com menos de 700 mil metros quadrados de área verde, ou seja, um metro por munícipe, e a população crescia $50 \%$ a cada década. Em face dos pouquíssimos terrenos municipais disponíveis, técnicos e vereadores preocupavam-se com a gravidade da situação, que poderia se tornar insustentável se não fossem tomadas providências urgentes (CAMPOS, 2002, p.312).

Nem todos, contudo, partilhavam dessa opinião. Era bastante disseminada a teoria de que, São Paulo era uma "cidade rala", de baixa densidade de ocupação, abundante em terrenos vagos e espaços livres e que, portanto, não teria grande necessidade de parques públicos. Efetivamente, em 1914, com menos de quinhentos mil habitantes, São Paulo ocupava uma área equivalente a Paris (Santos, apud FURLAN, 2004, p.263). A presença de parques particulares havia disfarçado a carência de áreas públicas de lazer, que veio à tona quando todas essas matas foram impiedosamente loteadas na década de 1920. Da mesma forma, a dispersão de sua ocupação urbana, até aquele momento, criava a ilusão de uma cidade imersa no verde (CAMPOS, 2002, p.312-313).

$\mathrm{Na}$ verdade, mesmo comparada às cidades norte-americanas menos densas, como Filadélfia e Saint Louis, São Paulo encontrava-se em situação flagrantemente inferior em termos de provisão de áreas verdes. Além disso, podia-se prever que a densidade da construção aumentaria a cada dia, de modo que desapareceriam jardins, pátios e quintais particulares e a cidade terminaria por ser compacta. Era previsível já na década de 1920 que São Paulo viria a ser, no tocante a áreas verdes, uma das mais desfavorecidas entre as grandes cidades modernas (CAMPOS, 2002, p.313). 
No sentido de ampliar os espaços verdes do Município de São Paulo, medidas também estavam sendo tomadas pelo Estado. Em 1929 seria implantado o atual Jardim Botânico de São Paulo na então chamada "Mata do Governo", destinada à proteção das nascentes do riacho do Ipiranga e que viria a se chamar Parque do Estado em 1929. O Jardim Botânico tornar-se-ia autônomo com a criação em 1938 do Departamento de Botânica, integrante da Secretaria Estadual da Agricultura (GUARALDO, 2002, p.92). Ao lado deste, seria inaugurado o Parque Zoológico de São Paulo em 16 de maio de 1958, que seria administrado, a partir de 1959, pela Fundação Parque Zoológico de São Paulo, atualmente vinculada à Secretaria Estadual do Meio Ambiente (FUNDAÇÂO PARQUE ZOOLÓGICO DE SÃO PAULO). O Parque do Estado teve sua denominação alterada para Parque Estadual das Fontes do Ipiranga, tornando-se unidade de conservação integrante do SNUC.

Enquanto isso o Parque do Ibirapuera permanecia no papel, em vários projetos não efetivados. É interessante destacar que essa inércia provocou uma rara, para aquela época, manifestação da sociedade civil. Em 14/05/1947, a "Sociedade Amigos da Cidade", na época presidida pelo ex-prefeito Goffredo T. da Silva Telles, enviou carta ao então prefeito Christiano das Neves, tecendo uma série de considerações sobre as áreas verdes, de importância não apenas decorativa, mas fundamental para a saúde pública e recreio da população; sobre a grave situação da cidade, com apenas meio metro quadrado de verde por habitante; que o ideal, segundo especialistas, não deveria ser inferior a sete ou oito metros quadrados por habitante; com relação ao seu crescimento e adensamento que ia rapidamente substituindo quintais e jardins privados por edificios de apartamentos, o que agravaria ainda mais a situação; que nesse ritmo, logo existiria apenas um quarto de metro quadrado de verde por habitante; da necessidade do poder público tomar medidas urgentes para implantação de parques na cidade, citando vários exemplos estrangeiros; finalmente pedindo a urgente implantação do Parque do Ibirapuera, ainda que com várias mutilações de área, algumas das quais, indesculpavelmente, por iniciativa oficial (SOCIEDADE AMIGOS DA CIDADE, 1950, p.05-08). 
Lamentavelmente, nada foi feito. Após marchas e contramarchas, o Parque do Ibirapuera somente seria implantado em 1953, para sediar a Exposição do IV Centenário de São Paulo (MARIANO, 1992, p.97). Deste parque trataremos em mais detalhes no capítulo seguinte.

Após a implantação do Ibirapuera, viriam os anos de 1960, com uma importante reforma tributária em 1967, pela qual parte da arrecadação de tributos efetuada nas esferas estadual e federal seria repassada aos Municípios. Desse modo, praticamente triplicaram as receitas do Município de São Paulo, cujo orçamento ainda foi beneficiado pela fase expansiva do modelo industrial brasileiro, entre 1968 e 1973, o chamado "milagre brasileiro" (BARTALINI, 1999, p.113).

Assim, no final da década de 1960, São Paulo era não só a maior metrópole brasileira, em área e população, como também uma das maiores do mundo. A área do município estendia-se por $700 \mathrm{~km} 2$ e sua população chegava perto de 6 milhões de pessoas. A continuidade urbana, que em décadas anteriores chegara a São Caetano do Sul e Santo André, verificava-se na entrada dos anos 1960 também para os lados de Guarulhos, Poá, Ferraz de Vasconcelos, Itaquaquecetuba e Suzano (Singer, apud BARTALINI, 1999, p.113).

Em contrapartida, o desenvolvimento atraíra correntes migratórias internas, sem que a cidade estivesse preparada para atender ao grande crescimento da demanda por serviços e equipamentos urbanos. Por volta de 1968, quase metade da população não era atendida por rede pública de água, mais de $60 \%$ não era servida por rede de esgoto. Também $60 \%$ das vias oficiais não eram pavimentadas e $76 \%$ não dispunham de iluminação. A distribuição destas carências era desequilibrada, penalizando as áreas mais pobres da cidade (PMSP, apud BARTALINI, 1999, p.113).

Com as verbas disponíveis reforçadas, os prefeitos da época investiram em várias obras, especialmente naquelas necessárias para implantação ou complementação do plano viário que havia sido elaborado há décadas por Prestes Maia. Nas desapropriações, na execução de avenidas e viadutos, bem como nas obras 
iniciais do metrô, foi aplicada•a maior parte dos recursos municipais (BARTALINI, 1999, p.114).

Apesar da situação financeira favorável, praticamente nada foi feito em termos de áreas verdes até 1974 (BARTALINI, 1999, p.114). Basta verificar que em 1930 havia $0,75 \mathrm{~m} 2$ de área de parque por habitante. Já em 1965, havia apenas 0,50 m2 de área de parque por habitante em São Paulo (Idem, p.104).

Entre 1953 e 1974, foi implantado apenas um parque urbano em São Paulo, o Bosque do Morumbi, hoje denominado Parque Alfredo Volpi, em 1966, sem despesas de desapropriação, já que se tratava de área doada pelo loteador em 1949 (BARTALINI, 1999, p.110).

A partir de 1974 houve uma razoável melhora nesse quadro. Entre 1974 e 1981 foram construídos onze parques, num total de 1.200 hectares, dos quais 1.150 hectares correspondiam a terrenos desapropriados pela municipalidade. Mesmo descontando a área do Parque Anhangüera, excepcionalmente grande, chega-se a 220 hectares de novos parques. Entre 1981 e 1995, as ações municipais para suprir a cidade de áreas verdes públicas foram bem menos significativas. Neste último período também foram construídos onze parques, mas num total pouco maior que 60 hectares. Dos onze novos parques, nove eram espaços livres de loteamento, portanto bens que não precisaram ser adquiridos, sendo cinco deles antigas "praças", que para se tornarem "parques", apenas passaram por reformas de pouca monta e foram cercados (BARTALINI, 1999, p.114-115).

Atualmente existem trinta e um parques urbanos municipais na cidade de São Paulo, com uma área total de 1.422,90 hectares, que corresponde a apenas 0,93 $\%$ do seu território (SVMA e IPT, 2004, p.94). São eles os seguintes, em ordem alfabética (Idem, p.98):

(1) da Aclimação; (2) Alfredo Volpi; (3) Anhangüera; (4) Buenos Aires; (5) Burle Marx; (6) do Carmo; (7) Chácara das Flores; (8) Chico Mendes; (9) Cidade de Toronto; (10) dos Eucaliptos; (11) Guarapiranga; (12) do Ibirapuera; (13) Independência; (14) Jardim da Felicidade; (15) Lina e Paulo Raia; (16) Lions Clube 
Tucuruvi; (17) Luiz Carlos Prestes; (18) da Luz; (19) Nabuco; (20) do Piqueri; (21) da Previdência; (22) Raposo Tavares; (23) Raul Seixas; (24) Rodrigo de Gasperi; (25) Santa Amélia; (26) Santo Dias; (27) São Domingos; (28) Severo Gomes; (29) Tenente Siqueira Campos; (30) Vila dos Remédios e (31) Vila Guilherme.

Em 2004, segundo SVMA e IPT (2004, p.141-142), havia quinze novos parques urbanos em construção e trinta e seis em projeto.

O Estado de São Paulo também mantém alguns parques urbanos no Município de São Paulo. São eles: Parque Fernando Costa (Água Branca) (PACHECO, 1983, p.147-149); Parque. Ecológico do Tietê (núcleo Engenheiro Goulart), com 1.200 hectares, nos município de São Paulo e Guarulhos (DAEE); Parque Ecológico da Guarapiranga, com 264 hectares (PREFEITURA DA CIDADE DE SÃO PAULO), Parque Villa Lobos, com $732 \mathrm{mil} \mathrm{m2} \mathrm{(GOVERNO} \mathrm{DO} \mathrm{ESTADO}$ DE SÃO PAULO); Parque da Juventude, com'240 mil m2 previstos (SECRETARIA DA JUVENTUDE ESPORTE E LAZER); Parque Tizo, cuja denominação oficial é Parque Urbano para a Conservação e Lazer na Fazenda Tizo, com 150 hectares, que envolve áreas de São Paulo, Osasco, Cotia, Taboão da Serra e Embu (CETESB, 2006) e o Parque Belém, com área prevista de 255 mil m2 (SECRETARIA DA JUSTIÇA).

4.6.4. Parques urbanos e o plano diretor da cidade de São Paulo

Plano diretor é o instrumento básico da política de desenvolvimento e de expansão urbana. É obrigatório para as cidades com mais de vinte mil habitantes e deve ser aprovado por lei municipal (Constituição Federal, art. 182, $\S 1^{\circ}$ ).

O plano diretor deve organizar o funcionamento e o crescimento da cidade. Ele deve estender-se a todo o território do município, independentemente das funções de cada parte da cidade, sejam elas atividades urbanas ou rurais. Não é 
incomum que seja criado por consultorias ou grupos de técnicos especializados, por se tratar inicialmente de um instrumento técnico; porém, também é um instrumento político, que deve compactuar os interesses comuns de toda a sociedade. Por isso é fundamental que a mesma participe dessa criação, em todas as etapas, desde as reuniões iniciais para o estabelecimento de metas até as ações finais dos programas e projetos (SILVA, 2008, p.07).

O Plano Diretor Estratégico do Município de São Paulo, que entrou em vigor pela Lei 13.430, de 13/09/2002 (SÃO PAULO, 2002, 01-204), contém vários dispositivos que, direta ou indiretamente, aplicam-se aos parques urbanos. Os mais importantes, em nosso entendimento, passamos a relacionar abaixo.

Entre os princípios do plano diretor (art. $7^{\circ}$ ), temos o direito ao lazer para todos (inc. III) e a preservação e recuperação do ambiente natural (inc. IX). São objetivos decorrentes desses princípios (art. $8^{\circ}$ ): elevar a qualidade do ambiente urbano por meio da preservação de recursos naturais (inc. IV) e garantir a todos os habitantes da cidade o acesso ao uso dos espaços abertos e verdes (inc. V). Segundo o art. $9^{\circ}$, é objetivo da política urbana ordenar o pleno desenvolvimento das funções sociais da cidade e o uso socialmente justo e ecologicamente equilibrado e diversificado de seu território, de forma a assegurar o bem-estar equânime de seus habitantes mediante, entre outras ações, a redução dos deslocamentos entre a habitação e o lazer (inc. IV) e a preservação, proteção e recuperação do meio ambiente e da paisagem urbana (inc. VI), sendo função social do município (§ único do art. $9^{\circ}$ ) garantir a qualidade ambiental e paisagística (inc. II).

Entre as diretrizes da política urbana (art. 10) encontramos a utilização racional dos recursos naturais de modo a garantir uma cidade ambientalmente sustentável para as presentes e futuras gerações (inc. II); a gestão democrática por meio da participação da população e de associações representativas de vários segmentos da comunidade na formulação, execução e acompanhamento de planos, programas e projetos de desenvolvimento urbano, principalmente aqueles que trazem mais riscos ao meio ambiente natural (inc. IIl); a ordenação e o controle do uso do solo, de forma a combater e evitar: a poluição e a degradação ambiental, a excessiva 
ou inadequada impermeabilização do solo e o uso inadequado de espaços públicos (inc. VII, letras $f, g$ e h); a proteção, preservação e recuperação do meio ambiente natural (inc. XI).

A propriedade urbana para cumprir sua função social precisa atender, simultaneamente, entre outros requisitos, a compatibilização do uso da propriedade com a preservação da qualidade do ambiente urbano e natural (art. 11, caput e inc. III). A função social da propriedade deverá subordinar-se às exigências fundamentais de ordenação da cidade expressas no plano diretor e no art. 151 da Lei Orgânica do Município (art. 12), compreendendo a distribuição de usos e intensidades de ocupação do solo de forma equilibrada em relação ao meio ambiente (inc. I); a melhoria da paisagem urbana, a preservação dos recursos naturais e dos mananciais de abastecimento de água do Município (inc. IV) e a recuperação das áreas degradadas visando a melhoria do meio ambiente (inc. V). É objetivo do desenvolvimento econômico e social sintonizar o desenvolvimento econômico da cidade e a sua polaridade como centro industrial, comercial e de serviços com a proteção ao meio ambiente (art. 14, caput). Entre as diretrizes do desenvolvimento econômico e social está a articulação das diversas políticas sociais com a política econômica, potencializando as ações públicas e compatibilizando crescimento econômico com equilíbrio ambiental (art. I5, inc. VI).

São objetivos da política ambiental (art. 55): implementar as diretrizes contidas na política nacional de meio ambiente (inc. I); proteger e recuperar o meio ambiente e a paisagem urbana (inc. II); ampliar as áreas integrantes do sistema de áreas verdes do Município (inc. V); incentivar a adoção de hábitos, costumes, posturas, práticas sociais e econômicas que visem a proteção e restauração do meio ambiente (inc. VI); preservar os ecossistemas naturais e as paisagens notáveis (inc.VII). Dentre as ações estratégicas para a gestão ambiental (art. 57), temos a de implantar parques lineares dotados de equipamentos comunitários de lazer, como forma de uso adequado de fundos de vale, desestimulando invasões e ocupações indevidas (inc. II). 
São objetivos da política de áreas verdes (art. 58): ampliar as áreas verdes, melhorando a relação área verde por habitante no Município (inc. I) e assegurar usos compatíveis com a preservação e proteção ambiental nas áreas integrantes do sistema de áreas verdes do Município (inc. II). São diretrizes relativas à política de áreas verdes (art. 59): o adequado tratamento da vegetação enquanto elemento integrador na composição da paisagem urbana (inc. I); a gestão compartilhada das áreas verdes públicas significativas (inc. II); a incorporação de áreas verdes significativas particulares ao sistema de áreas verdes do Município, vinculando-as às ações da municipalidade destinadas a assegurar seu uso e preservação (inc. III); a manutenção e ampliação da arborização de ruas, criando faixas verdes que conectem praças, parques ou áreas verdes (inc. IV); a criação de iństrumentos legais destinados a estimular parcerias entre os setores público e privado para implantação e manutenção de áreas verdes e espaços ajardinados ou arborizados (inc. V); a recuperação de áreas verdes degradadas de importância paisagístico-ambiental (inc. VI); o disciplinamento do uso, nas praças e nos parques municipais, das atividades culturais e esportivas, bem como dos usos de interesse turístico, compatibilizando-os ao caráter essencial desses espaços (inc. VII) e a criação de programas para a efetiva implantação das áreas verdes previstas em conjuntos habitacionais e loteamentos (inc. VIII). São ações estratégicas para as áreas verdes (art. 60): implantar áreas verdes em cabeceiras de drenagem e estabelecer programas de recuperação (inc. I); implantar o conselho gestor dos parques municipais (inc. II); instituir a taxa de permeabilidade, de maneira a controlar a impermeabilização (inc. III); criar interligações entre as áreas verdes para estabelecer vínculos de importância ambiental regional (inc. IV); criar programas para a efetiva implantação das áreas verdes previstas em conjuntos habitacionais e loteamentos (inc. V); implantar programa de arborização nas escolas públicas municipais (inc.VI); utilizar áreas remanescentes de desapropriações para implantação de parques e praças (inc.VII); estabelecer parceria entre os setores público e privado, por meio de incentivos tributários, para implantação e manutenção de áreas verdes e espaços ajardinados ou arborizados, atendendo a critérios técnicos de uso e preservação das áreas, estabelecidos pelo executivo municipal (inc. VIII) e 
elaborar mapa de áreas verdes do Município, identificando em cada distrito as áreas verdes (inc. IX).

Entre os objetivos do sistema de drenagem urbana (art. 67), está a interrupção do processo de impermeabilização do solo (inc. III). Nas diretrizes para o sistema de drenagem urbana (art. 68) encontramos a definição de mecanismos de fomento para usos do solo compatíveis com áreas de interesse para drenagem, tais como parques lineares, áreas de recreação e lazer e manutenção de vegetação nativa (inc. III). Entre as ações estratégicas da política de urbanização e uso do solo (art. 78) estão: requalificar o centro histórico e seu entorno, destacando-se a Várzea do Carmo e o Parque D. Pedro (inc. VI) e desenvolver projeto de requalificação da área do Carandiru para permitir a preservação da área verde existente e dos edifícios protegidos por tombamento, além da implementação de novas atividades e usos, em especial parque urbano (inc. XVI).

São diretrizes para a política habitacional (art. 80), entre outras, a garantia, nos programas habitacionais, de atividades conjuntas de proteção ao meio ambiente e de educação ambiental, de modo a assegurar a preservação das áreas de mananciais e a não-ocupação das áreas de risco e dos espaços destinados a bens de uso comum da população, através de parcerias de órgãos de governo e organizações não-governamentais (inc. XII); o respeito ao meio ambiente, buscando adotar tecnologias de projeto, construção e manutenção dos empreendimentos habitacionais voltados para os princípios do desenvolvimento sustentável, incluindo-se alternativas de conservação da água e de disposição de resíduos sólidos, além de recuperação de áreas verdes, preservação ambiental e de reciclagem dos resíduos inerentes aos empreendimentos (inc. XVIII) e a promoção de serviços de assessoria ambiental gratuita a indivíduos, entidades, grupos comunitários e movimentos na área da habitação social, no sentido de promover a inclusão social desta população (inc. XXII). Dentre as diretrizes para as áreas públicas (art. 86), temos: destinação prioritária dos bens públicos dominiais não utilizados para assentamentos da população de baixa renda, para áreas verdes e instalação de equipamentos coletivos (inc. V); implantação de praças e equipamentos sociais, com a participação dos 
beneficiados pelas operações (inc. VI); criação de legislação de uso e ocupação do solo para as áreas e prédios públicos, visando atender às demandas de equipamentos e serviços públicos, garantindo a preservação e a recuperação do meio ambiente (inc. VII).

Incluída entre as diretrizes para a política relativa ao patrimônio histórico e cultural (art. 89) está a elaboração de normas para a preservação de bens culturais, vegetação significativa e referências urbanas (inc. I). São objetivos da política de paisagem urbana (art. 91): garantir a qualidade ambiental do espaço público (inc. II); favorecer a preservação do patrimônio cultural e ambiental urbano (inc. V). Já entre as diretrizes da política de paisagem urbana (art. 92) estão: a disciplina do ordenamento dos elementos componentes da paisagem urbana, favorecendo a preservação do patrimônio cultural e ambiental urbano (inc. II) e a implementação de programas de educação ambiental visando conscientizar a população a respeito da valorização da paisagem urbana como fator de melhoria da qualidade de vida (inc. IV).

Segundo o art. 101, caput, do plano diretor (Lei 13.430/2002), a urbanização do território do Município se organiza em torno de nove elementos, quatro estruturadores e cinco integradores. São elementos estruturadores os eixos que constituem o arcabouço permanente da cidade, os quais, com suas características diferenciadas, permitem alcançar progressivamente maior aderência do tecido urbano ao sitio natural, melhor coesão e fluidez entre suas partes, bem como maior equilibrio entre os espaços construidos e os espaços abertos $\left(\S 1^{\circ}\right.$ do art. 101). Os elementos integradores constituem o tecido urbano que permeia os eixos estruturadores e abriga as atividades dos cidadãos que deles se utilizam ( $\S 2^{\circ}$ do art. 101). Entre estes últimos encontramos as áreas verdes, definidas como o conjunto de espaços arborizados e ajardinados, de propriedade pública ou privada, necessários à manutenção da qualidade ambiental e ao desenvolvimento sustentável do Municipio (inc. III, do $\S 2^{\circ}$ do art. 101).

O sistema de áreas verdes do Município é constituído pelo conjunto de espaços significativos, ajardinados e arborizados, de propriedade pública ou privada, necessários á manutenção da qualidade ambiental urbana tendo por objetivo a 
preservação, proteção, recuperação e ampliação desses espaços (art. ‘131). Na verdade, são integrantes desse sistema todas as áreas verdes existentes e as que vierem a ser criadas, de acordo com o nivel de interesse de preservação e proteção (art. 132).

Entre essas áreas verdes estão relacionados os "parques urbanos" como áreas verdes de uso sustentável (art, 132, inc. II, letra f). Em seguida, vemos os “parques públicos” serem considerados como áreas verdes públicas (art. 133, inc. I, letra b). Apesar da imprecisão dos conceitos, pela natureza eminentemente pública do uso dos parques urbanos, parece-me que "parque urbano" deve ser considerado sinônimo de "parque público". Portanto, o plano diretor considera os parques urbanos como áreas verdes públicas, de uso sustentável.

Uma modalidade específica de parque urbano, o parque linear, é tratado com destaque especial pelo plano diretor.

O parque linear, segundo FALCÓN (2007, p.47), é um tipo de área verde pouco estudado pelo urbanismo e pelo planejamento urbano. Os valores ambientais que o norteiam resultam do desenvolvimento de outra disciplina: a ecologia, eis que os parques lineares atuam como conectores de diferentes zonas verdes e como correia de transmissão da biodiversidade urbana. Sua função na trama urbana ultrapassa os aspectos ambientais, já que atua como um instrumento de coesão social. Os parques lineares oferecem beneficios sociais e culturais, já que se projetam como um trajeto que percorre diferentes bairros e partes da cidade, adaptando-se aos costumes e características dos habitantes dos locais por onde ele passa. Segundo este conceito, o parque linear não é um destino, mas um percurso que 'contribui para marcar tanto as diferenças como a diversidade de cada bairro, o que aprimora aqueles que o utilizam. Este autor ainda explica que os parques lineares, para que sejam assim considerados, devem ter largura mínima de vinte e cinco metros, serem reservados para pedestres e ciclistas e disponham de distribuição espacial marcada pela vegetação, que unifique o passeio com as zonas de repouso, dọtadas de mobiliário urbano e, ocasionalmente, de playgrounds. 
Os parques lineares, nesses termos, exercem um papel semelhante no meio urbano ao que os corredores ecológicos exercem para as unidades de conservação integrantes do SNUC, conforme o inc. XIX do art. $2^{\circ}$ da Lei 9.985 de 18/07/2000. Os parques lineares da cidade de São Paulo têm características um tanto diferentes.

Os principais objetivos do parque linear são ampliar as áreas verdes permeáveis ao longo de fundos de vale, minimizando fatores causadores de enchentes e danos delas decorrentes; ampliar espaços de lazer ativo e contemplativo; ampliar e articular espaços de uso público, em particular os arborizados e destinados à circulação e bem-estar de pedestres; integrar áreas de vegetação significativa, visando a sua proteção e preservação; recuperar áreas degradadas e mobilizar a população envolvida em cada projeto, de modo a obter sua participação (SVMA e IPT, 2004, p. 142).

Os parques lineares devem observar as seguintes diretrizes: (a) a faixa de quinze metros ao longo de cada uma das margens dos cursos d'água e fundos de vale como área nom aedificandi; (b) a planície aluvial com prazos de recorrência de chuvas de vinte anos e as áreas de vegetação significativa ao longo dos fundos de vale do município, que juntamente com a área nom aedificandi formarão os parques lineares; (c) as áreas contidas na faixa de até duzentos metros de largura, medidos a partir do limite do parque linear coincidente com a planície aluvial, destinadas à implantação de empreendimentos residenciais, a serem executados pela iniciativa privada. É possível que a planície aluvial não exista, como nos cursos d'água encaixados, possibilitando a delimitação da faixa de até duzentos metros e a permissão de empreendimentos imobiliários, associados à implantação de parcela do parque linear, sem ônus para o Município (SEMPLA, 2004, p.150).

Quando se tratar de zona rural do Município, a faixa deve ser ampliada para trinta metros de largura ao longo de cada margem. Nessa zona o parque linear só precisa ser implantado nas áreas já urbanizadas. Naquelas não urbanizadas devem ser criados novos parques ou estes serem classificados como unidades de conservação (SEMPLA, 2004, p.151). 
Segundo SVMA e IPT (2004, p.142), está prevista, até 2012, a criação de cento e oitenta parques lineares ao longo de cursos d'água em vinte e oito subprefeituras de São Paulo.

\subsection{ESTUDOS DE CASO: PARQUES DA LUZ, TENENTE SIQUEIRA} CAMPOS (TRIANON), DA ACLIMAÇÃO E DO IBIRAPUERA

No sentido de analisar os problemas que comumente prejudicam a preservação, a conservação e a utilização pela população dos parques urbanos da cidade de São Paulo, foram selecionados quatro parques urbanos municipais para estudo: Luz, Siqueira Campos, Aclimação e Ibirapuera.

Estes parques foram escolhidos por estarem entre os mais antigos e tradicionais, mais visitados e com maiores ligações afetivas com a população. Talvez, por esses mesmos motivos, eles também foram os mais visados para redução de área e descaracterização de usos. Sofreram também constantes voltas e reviravoltas no seu prestígio e estado de conservação, ao sabor das administrações públicas que se foram sucedendo através do tempo.

O Parque da Luz é o mais antigo e tradicional de São Paulo. Os Parques Siqueira Campos e da Aclimação são antigos parque particulares que sobreviveram . ao serem adquiridos pela municipalidade, se bem que o segundo ainda tenha sofrido várias mutilações. O Parque do Ibirapuera, enfim, é o mais conhecido e visitado parque urbano paulistano. 
4.7.1. Parque da Luz

4.7.1.1. Origens: Horto ou Jardim Botânico

MARQUES (1980, v.2, p.12-13) informa que, por Aviso Régio de 19 de novembro de 1798, foi ordenada a criação de um Jardim Botânico ao governador e capitão-general de São Paulo, Antônio Manuel de Melo Castro e Mendonça. Para tanto, segundo MARTINS (1973, p.127), foram concedidas pelo Senado da Câmara ao sargento-mor Antônio Marques da Silva, inspetor da obra, em 28 de setembro de 1799, no bairro da Luz, "vinte datas de terras com testada de 273 braças [600,60 metros, segundo JORGE, 1988, p.53] contadas desde os muros do padre capelão até o ângulo defronte ao Espaldão", área que entrou no domínio da Capitania. Ainda de acordo com MARTINS (1973, p.127), por ofício datado de 21 de fevereiro de 1800 , o mesmo capitão-general informou a D. Rodrigo de Souza Coutinho, ministro e secretário de estado da Corte, as providências tomadas para a formação de um horto botânico semelhante àquele que na Capitania do Pará havia sido feito por D. Francisco de Souza Coutinho, governador e capitão-general da mesma capitania.

O Horto Botânico, como foi a princípio denominado, começou por meio de subscrição por pessoas gradas da capital, que receberam em troca patentes de oficiais de milícia. Em tal subscrição obteve-se a importância de 6:906\$000, parte da qual foi ainda empregada na construção do Hospital Militar, que acabaria sendo construído na Rua do Seminário, em cujo edifício, já desaparecido, funcionou o Seminário das Educandas a partir de 1825 (MARTINS, 1973, 127-128).

Em fins de 1802 Castro e Mendonça deixou a capitania, aparentemente sem concretizar o Horto Botânico (SEGAWA, 1996, p.132). 
Segundo MARQUES (1980, v.2, p.13) o Jardim Botânico somente foi concluído no governo do primeiro presidente provincial, Lucas Antônio Monteiro de Barros, futuro visconde de Congonhas do Campo, que com a autorização do Governo Imperial, dada por aviso de 8 de outubro de 1825 , abriria a área ao recreio público. Ainda a 29 do mesmo mês e ano nomeou o então marechal de campo José Arouche de Toledo Rendon como seu primeiro diretor. De acordo com JORGE (1988, p.54), o Jardim Botânico ainda não estava terminado, tanto que tal nomeação visava a continuidade e finalização da obra, sendo o marechal Arouche a pessoa mais adequada para dirigi-la uma vez que, dentre outras qualidades, apresentava a de ter introduzido na Província de São Paulo a plantação de chá e a sua preparação.

Segundo SEGAWA (1996, p.133), a inauguração do Jardim Botânico de São Paulo, ocorrida pouco mais de dois meses após o de Ouro Preto, provavelmente foi uma grande improvisação, sem qualquer direcionamento para efetivamente instalar um horto com preocupações científicas e técnicas.

Toledo Rendon aceitou a incumbência, mas pouco demoraria na direção, sendo substituído pelo tenente-coronel Antônio Maria Quartim. Nessa gestão, a 21 de Abril de 1827, por ordem do presidente provincial Tomás Xavier de Almeida, dando cumprimento á deliberação do Governo Imperial, se procederia à avaliação daquele próprio da Fazenda Nacional (JORGE, 1988, p.54).

Sua configuração, quando da avaliação, era a seguinte (MARTINS, 1973, p.128):

"O Jardim Botânico, situado no Campo da Luz, por detrás do edificio principiado que se destinava para Hospital Militar, com frente para o mesmo Campo da Luz; cujo terreno pelo lado da frente, compreende cinqüenta e nove braças e meia [130,90 metros, segundo JORGE, 1988, p.54], até dar na estrada que se segue do Campo da Luz para a chácara do brigadeiro Bauman, onde formando um ângulo obtuso pelo lado esquerdo, fazendo frente para a chácara do coronel Antônio Leite, compreendendo cento e trinta e oito braças [303,60 metros, segundo JORGE, 1988, p.54]; e pelos fundos, formando outro ângulo obtuso e fazendo frente com os valos da chácara do falecido marechal Gavião, noventa e três braças e meia [205,70 metros, segundo JORGE, 1988, p.54] e dai em linha reta, fazendo frente com a travessa que sai para a rua Alegre [hoje rua Brigadeiro Tobias], com 
noventa braças [198 metros, segundo JORGE,1988, p.54] até encontrar com os muros do edifício principiado para Hospital Militar, e pelos quais, seguindo em linha reta até fechar a quadra compreendendo-se o numero de cento e cinqüenta e seis braças [343,20 metros, segundo JORGE, 1988, p.54] cujo terreno acha-se cercado de muros novos, de 14 palmos [3,08 metros, segundo JORGE, 1988, p.54] de alto; o que tudo sendo visto pelos ditos avaliadores, avaliaram: o terreno em a quantia de um conto de réis; e os muros em uma quantia de um conto e seiscentos mil réis; mais que tudo soma dois contos e seiscentos mil réis".

Segundo KLIASS (1993, p.68), tal perímetro correspondia a uma área de aproximadamente 105 mil metros quadrados, a qual se mantinha ainda em 1841, de acordo com planta elaborada por C. A. Bresser.

Conforme JORGE (1988, p.54-55) a medição efetuada dá a entender que a área abrangida pelo jardim começaria num segmento da atual rua Mauá, travessa da rua Brigadeiro Tobias, prolongando-se, pelo lado esquerdo, até a vizinhança fronteira ao Recolhimento da Luz. Mas, confrontando-se os sucessivos mapas da cidade, desde 1810 , observa-se que o terreno sofreu, no correr do tempo, algumas mutilações e acabou por adquirir uma forma pentagonal. $\mathrm{O}$ que infelizmente é fato comum na história dos parques urbanos de São Paulo.

A partir dessa configuração, SEGAWA (1996, p.133) afirma que o jardim era um recinto fechado, situado em área rural, haja vista a vizinhança de chácaras.

Em 1830 o então Jardim Botânico estava realmente abandonado. Tanto que, de acordo com MARTINS (1973, p.131), o Dr. José Carlos Pereira de Almeida Torres, décimo-quarto presidente provincial, teve desagradável surpresa ao inspecioná-lo na tarde de 6 de Março de 1830, quando verificou que o local fora transformado em pasto de gado, tendo encontrado, soltos, dentro do mesmo jardim, oito bois de carro e um cavalo, que soube pertencerem ao jardineiro alemão que ali não se achava; foi informado de que o abuso datava já de muito tempo e que no lugar onde estavam os bois se havia feito uma plantação de capim à custa da fazenda pública. Encontrou ainda num rancho existente no mesmo jardim e pertencente à Nação, três mulheres "sem fazerem nada" e observou estarem trabalhando ou "enchendo o tempo", três estrangeiros que ganhavam cada um 420 réis por dia e um 
escravo da nação, sem que tivesse quem os inspecionasse e dirigisse. O resultado dessa inspeção foi o despedimento do jardineiro que ganhava $25 \$ 600$ mensais, motivada ainda pelo fato de o mesmo produzir carvão e mandá-lo vender na cidade, por empregado do referido jardim.

Em 1835, o presidente da provincia Rafael Tobias de Aguiar, conforme BRUNO (1954, v.2, p.533), dirigiu-se à Assembléia Provincial para tratar do ainda Jardim Botânico, demonstrando que o mesmo não estava terminado, embora já estivesse em uso como área de lazer:

"Continua-se a trabalhar no jardim estabelecido nesta cidade; ainda que seja uma despesa que mais toca ao agradável do que ao útil, não se pode dispensar, uma vez que ele já serve de recreio aos cidadãos em certos dias, e não é conveniente abandonar uma obra começada".

KIDDER (1972, p.191), pastor protestante americano que esteve em São Paulo em 1839, observa a beleza potencial da área, mas também o abandono do jardim:

\begin{abstract}
“Em um dos sítios mais amenos do lugar, a cerca de uma milha de distância, fica o Jardim Botânico fundado há mais de dez anos. Seu plano geral é de muito gosto, dispondo de alamedas curvilineas arborizadas e um esplêndido lago artificial de água límpida. Suas dimensões são amplas, e, se for bem cuidado, poderá constituir magnífico logradouro. Atualmente, porém está um tanto abandonado por falta de recursos do tesouro provincial".
\end{abstract}

Outro interessante relato é o de Vieira Bueno, apud BRUNO (1981, p.53), estudante de direito que viveu em São Paulo na década de 1830, que já chamava atenção para a ausência de pesquisa botânica:

"Para recreio da população havia somente o passeio. do campo da Luz, denominado Jardim Botânico, mas que nada tinha que justificasse tal denominação, pois era arborizado com plantas corriqueiras de nossas matas. De ornamentação 
havia apenas o lago central, com as duas estátuas de Vênus e Adônis".

4.7.1.2. Jardim Público a partir de 1838

Ao que tudo indica, a pouca ou nenhuma atividade botânica, levou a Assembléia Províncial em 1838 a mudar o nome do Jardim Botânico para Jardim Público, sem todavia renunciar ao eventual aproveitamento para fins botânicos (SEGAWA, 1996, p.134). No mesmo ano Venâncio José Lisboa assumiria a presidência da província e, entre outras deliberações, nomearia para o cargo de diretor Antônio Bernardo Quartim, filho do antigo diretor; além de expor à Assembléia Provincial a verdadeira situação do logradouro, sem água e trabalhadores, em razão do que solicitou verba de 300\$000 para reformas (JORGE, 1988, p.55).

Na presidência de Miguel de Souza Melo e Alvim (1841 a 1842) foi construído um muro na frente e assentado um portão de ferro com pilastras de cantaria, embora persistissem dois problemas: falta de água para irrigação e de iluminação noturna, uma deficiência geral da cidade (JORGE, 1988, p.55).

Informa o famoso naturalista e viajante francês SAINT- HILLAIRE (1976, p.131) que em 1844 o presidente da província Manuel Felizardo de Sousa e Melo declarou o seguinte à Assembléia Provincial: "traçado sobre um terreno vasto e perfeitamente regular, com aprazíveis aléias de árvores frutíferas e uma profusão de outras árvores tanto nativas quanto exóticas, e apresentando uma grande variedade de arbustos e de flores, o jardim público oferece aos habitantes de nossa cidade um lugar de lazer, onde eles aprendem a dar valor a todas as belezas da natureza". Segundo o mesmo autor, após esse panegírico, o presidente incitou os deputados a concordarem com alguns sacrificios, em prol do embelezamento do jardim, acrescentando, com bastante razão, que seria vantajoso formar-se nele um viveiro de 
árvores e outras plantas exóticas, cujas mudas seriam depois distribuidas entre os agricultores.

Em 1845 o marechal Manoel da Fonseca Lima e Silva, então presidente da província, em seu relatório à Assembléia Provincial diz: “que o antigo encanamento das águas do tanque reúno para a bacia da Pirâmide do Piques [Largo da Memória] e dali para o Jardim Botânico é o menos regular e bem feito que se pode observar em trabalhos desta natureza, donde têm resultado os reiterados desmoronamentos dos terrenos laterais e os freqüentes extravios das águas (...). Convém pois remediar este inconveniente por meio de um encanamento de pedra que, sendo coberto ao menos até a bacia da Pirâmide, abastecerá o chafariz ali há pouco edificado" (MARTINS,1973, p.132). Conclui-se do exposto que as águas fornecidas ao Jardim Botânico deveriam correr por valas a céu aberto.

Na gestão do presidente José Tomás Nabuco de Araújo (27/08/1851 19/05/1852), segundo MARTINS (1973, p.132), foi colocada uma grade de ferro na frente do Jardim Público, mas o pessoal que nele trabalhava, formado por africanos livres, era bastante limitado, de sorte que quase todo o serviço, senão todo ele, recaía sobre o feitor.

Nas acertadas palavras de JORGE (1988, p.55), os anos e as ocasionais providências em nada melhoraram o aspecto do intentado parque, pois ele poucos atrativos oferecia à população. Apesar de já despontarem conceitos urbanísticos referentes à necessidade de áreas livires ou verdes, pouco fizeram as autoridades para aparelhá-lo adequadamente. Limitavam-se a colocar grades e implantar serviços de pouca monta, ou então, a tentar o cultivo do bicho da seda, inábil critério para dotar um local destinado à recreação pública.

O presidente provincial José António Saraiva (1854 a 1856) tentou sanar essa falha, informando num de seus relatórios à Assembléia que adquirira no Rio de Janeiro variedades botânicas, mudas, plantas exóticas e flores para aclimatá-las no Jardim da Luz. Acresceu que três quartos da área, cerca de $60.000 \mathrm{~m} 2$, estavam plantados, faltando pessoal, verbas e principalmente, água (JORGE, 1988, p.55). 
Em 1858 o viajante alemão Lallemant, apud SEGAWA (1996, p.135) deixou registradas suas impressões sobre o Jardim Público, destacando sua beleza, mas não deixando também de observar que o mesmo estava mal cuidado:

"Devo primeiro mencionar um bonito e grande jardim que serve para passeio e instrução botânica. Surpreendeu-me agradavelmente, mais do que qualquer outra coisa em toda a cidade. Apesar de muita desordem e falta de cuidado, oferece ele, em alamedas e praças, pontos apraziveis e bonitos aspectos. Uma lindíssima flora de origem européia medra ao lado de eucaliptos da Austrália, a oliveira apraz-se ao lado da casuarina, palmeiras porfiam com macieiras e' outras árvores frutíferas nórdicas. Em torno de bonito e grande tanque, se comprimem bonitas flores, que oferecem um quadro aprazível e refrescante. A própria arte plástica, a mais nobre de todas, tentou embelezar o lugar com estátuas. Ainda que a boa vontade tenha superado a execução, o que se fez merece toda a estima".

Em 1860, o capitão Antonio Bernardo Quartim, no cumprimento de ordens do governo provincial, entregou à Companhia Inglesa (São Paulo Railway) "vinte braças [44 metros] de terreno da frente ao fundo" para a construção da estação ferroviária. Tal cessão iria prejudicar a disposição dos espaços arborizados com figueiras e modificaria o traçado de algumas ruas (MARTINS, 1973, p.134-135). O Parque da Luz seguia a sina dos parques urbanos paulistanos que é a de perder áreas para empreendimentos públicos, e até mesmo privados, com destruição da cobertura verde, de modo a demonstrar que a preservação ambiental está entre as últimas prioridades do poder público.

Conforme MARTINS (1973, p.132-133), em 1869, estando à frente dos destinos da província o senador Cândido Borges Monteiro, barão de Itaúna, recebeu o Jardim Público vários melhoramentos. Fora reconstruídas as paredes do lago do jardim e cimentada toda a sua superficie superior. Foi levantado o extremo do encanamento que despejava sobre o lago pela substituição de um cano bruto de pedra por uma cabeça de leão; foi reconstruída a escada respectiva, que ficou no centro de uma pequena cascata, que se desdobrava sobre um pequeno tanque, também reconstruído; aos lados desse tanque foram construídos dois assentos de tijolos. 
Também foram reconstruídos os pedestais de todas as estátuas, o muro que fecha a frente do jardim, impedindo assim a franca passagem de animais; consertadas as grades e portão de ferro. No centro do lago foi levantada uma ilha, sobre a qual foi colocada uma pequena casinhola rústica para servir de abrigo às aves aquáticas.

O novo encariamento, também construído nos inícios de 1869 , por ordem do mesmo barão de Itaúna, era formado de tubos de papelão asfaltado, o qual pouco durou (MARTINS, 1973, p.133). Não é de se estranhar que tenha havido tantos problemas com o abastecimento de água do parque.

Foi igualmente concedido ao diretor, capitão Quartim, o usufruto por 33 anos, em espaços do jardim, da área de 14x 28 braças (1.897,28 metros quadrados) para edificar residência. Todavia, Joaquim Saldanha Marinho, o novo presidente, revogaria a cláusula referente ao usufruto, por julgá-la inconveniente (JORGE, 1988, p.56). Entretanto, segundo KLIASS (1993, p.71), a casa do administrador foi então construída e permaneceu até 1901, quando foi substituída pela que existe até hoje.

O presidente João Teodoro Xavier de Matos (1872 a 1875), assinalado como grande reurbanizador da cidade, conforme os apontamentos de MARTINS (1973, p.133), mandou efetuar uma série de melhoramentos no Jardim. Estas consistiram na construção de uma torre para observatório, que importou em despesa de seis contos, na canalização das águas do tanque Reúno, em parte para alimentar o Jardim e colocação de quatro estátuas de mármore representando as quatro estações do ano e uma outra de Vênus, vindas do Rio de Janeiro, que lá estão até hoje. Também do Rio de Janeiro foram trazidas várias mudas de árvores e flores. Segundo JORGE (1988, p.56), com tais determinações solucionou-se o problema do abastecimento da água e a alimentação do tanque central.

Significativo marco na atuação de João Teodoro foi a construção da torre circular de tijolos, à maneira de mirante e observatório. A obra elevou-se com cerca de vinte metros de altura, fronteira à Estação da Luz e ganhou o apelido de "canudo do Dr. João Teodoro". Era uma peça arquitetônica edificada à imitação de farol marítimo, com escadas circulares internas, unindo os cinco andares, e desvões 
escuros que casais aproveitavam para atitudes menos escusas (JORGE, 1988, p.56). Em 1886, o presidente da província João Alfredo Correia de Oliveira propôs à Assembléia Provincial que se criasse uma repartição para observações meteorológicas a ser sediada no pequeno observatório do Jardim Público (MARTINS, 1973, p.134). Esta iniciativa não foi adiante, tanto que a torre foi fechada em 1890 e com base na Lei 496, de 14 de novembro de 1900, demolida, reutilizando-se o material para murar a parte inicial da rua dos Imigrantes, atual José Paulino, em paralelo com a linha ferroviária (JORGE, 1988, p.56). Nos dias atuais é possível ao visitante observar as fundações da referida torre.

Em 1877, Houssay, apud SEGAWA (1996, p.135), em carta para sua irmã, descrevia·o Jardim Público pela ótica de um francês romântico:

"No extremo ocidental de São Paulo se encontra um jardim impropriamente chamado Passeio Público, porque jamais encontrei por lá outro que não um velho jardineiro alemão."

"Nesse lugar solitário e perfumado se acham aqui e ali um pinheiro, um coqueiro, não sei que grandes árvores com ramos entrecruzados e agora sem folhagem; moitas, cercas vivas de rosas, pêssegos em flor; os arbustos e quatro caminhos de areia conduzem a um tanque octogonal, no qual as linhas curvas e a estatuária de mármore evocam a época de Luís XV. Eis meu querido Passeio."

"Mas tu não podes fazer uma idéia do repouso, da calma que ai se respira. Sob um céu azul pálido, o sol inunda tudo com uma luz torrencial. A brisa perpassa a folhagem e faz escutar a sua lânguida melodia. Os pássaros rodopiam cantando; as borboletas procuram as flores e, no caramanchão, onde encontro sombra e frescor, graciosas andorinhas voam no meu lado em desatino, fazendo sua alegre perseguição."

"O sussurro das folhas, o frescor da brisa, o canto dos pássaros, tudo leva à meditação."

Na presidência de Laurindo Abelardo de Brito (12/02/1879 - 04/03/1881) foi mandada fazer a gruta artificial que até hoje existe no Parque da Luz (MARTINS 1873, p.133). Também foi sancionada a Lei 21 de 15/02/1881 que autorizaria o aumento da sua área até a rua das Figueiras e despesas não superiores a !5:000\$000 (JORGE, 1988, p.58). 
Em 1881, o presidente provincial Senador Florêncio Carlos de Abreu e Silva mandou fazer novos fechos no Jardim porque os antigos ameaçavam ruína. Essas novas construções ficaram dez metros além do antigo muro, receebendo a obra 166 metros de elegante gradil de ferro, dividido em lances de pilastras de mármore verde, sendo delineado um suntuoso portão, flanqueado por quatro pilastras de mármore verde e preto, sendo o gradil e o portão realizados na antiga Fábrica de Ferro de São João Ipanema, tendo o orçamento da obra atingido o valor de 21:884\$730. Esse portão foi removido e o gradil rebaixado pela prefeitura em 1908 (MARTINS, 1973, p.133).

Nessa época o então Jardim Público parecia ter-se firmado como área de lazer. DINIZ (1978, p.75), em visita ocorrida em 1882, informa que:

"O jardim mais freqüentado, especialmente pelos estrangeiros, é o antigo da Luz: muitos melhoramentos se fizeram e alguns o embelezam. Nos domingos e quintasfeiras toca ali uma banda de música: é grande nesses dias a afluência do povo, que se concentra, em sua maior parte, na aléia de árvores seculares, perto das qual há dois coretos; o movimento de transeuntes aí não difere do que se dá nas ruas mais concorridas da cidade, em ocasiões de festas".

Apenas um ano depois, em 1883, o jornalista alemão Carl Von Koseritz, radicado no Rio Grande do Sul, também deixou escritas suas impressões:

"Finalmente o bonde parou no jardim, mas as grossas gotas que caíam afugentavam já os visitantes e a conhecida "Banda Alemã", que tinha tocado no jardim durante a tarde se retirava apressadamente. Nós, porém, enfrentamos a chuva e passeamos pelo jardim que é realmente uma jóia. Reúne o caráter do jardim ornamental ao do jardim botânico. $\mathrm{O}$ arranjo é ao gosto dos jardins paisagísticos: há grupos maravilhosos de árvores; moitas de arbustos com flores coloridas, lagos, canais, ilhas, rochedos e grotas; em suma, tudo o que se continha em um parque dos primeiros decênios deste século. As estátuas são sem valor artístico, mas agradam. No meio do jardim há um lago com um único bote que oferece, assim, na sua travessia, um prazer verdadeiramente singular. Há uma quantidade de plantas, árvores e arbustos raros, cuidadosamente tratados, mas faltam a palmeira imperial e a urânia, que tão bom efeito produzem no Rio (...) mas o jardim é bonito, e eu 
compreendo o amor dos paulistanos por ele" (KOSERITZ, 1972, p.260-261).

Outro interessante depoimento da mesma época, 1884, é aquele de Christopher C. Andrews, citado por BRUNO (1981, p.98), que foi cônsul geral dos Estados Unidos no Brasil, entre 1882 e 1885:

"Olhando-se da cidade em direção ao rio [Tietê], vê-se que a margem oposta é razoavelmente povoada e mais além há uma grande extensão de terra semelhante a um prado, que após uma distância de oito ou dez milhas encontra-se com uma cadeia de verdes colinas. É nessa parte baixa e nova da cidade que se encontra o Jardim Público. Passamos ali algumas horas, durante uma agradável manhã. Possui doze acres de terra e ainda sobra terreno para sua expansão. Vimos alamedas sombreadas e seus bonitos lagos artificiais. Uma das principais atrações é o renque de figueiras ou árvores de figos selvagens, que se assemelham ao carvalho americano. Entre as variedades de árvores encontrei dois pequenos carvalhos brancos, que são americanos ou ingleses."

"Esse jardim revela, realmente, muito gosto e capricho. Há nele uma torre alta e graciosa, usada como observatório e o superintendente tem sua residência no próprio parque. Nada, em minha opinião, confere mais crédito a uma povoação, que um terreno amplo e bem conservado, em local apropriado para jardim público ou parque. Este não foi feito para os veículos e sim para os pedestres."

Nessa mesma época, Mota, apud BRUNO (1981, p.112) informa que:

“À noite os pontos mais movimentados eram as confeitarias e cafés; o Jardim do Palácio, onde o povo afluía para ouvir música, ora a banda da Força Pública, ora a dos Bombeiros; o Jardim da Luz, que em dias marcados se enchia à tardinha de povo para ouvir música. Mas, acabado o concerto, o povo sumia-se como por encanto e as ruas ficavam vazias." 


\subsubsection{Municipalização na República}

Já na República, pela Lei Estadual 41 de 11/07/1892 e Decreto Estadual 145 de 05/01/1893 o Jardim Público foi transferido à municipalidade de São Paulo (MARTINS, 1973, p.135). Segundo MACEDO e SAKATA (2002, p.172), a partir de então ele passou a ser conhecido como Jardim da Luz

No final do século XIX o Jardim da Luz perde grandes áreas. Em seus terrenos é aberta a rua José Paulino, em razão de contrato celebrado entre a superintendência da Estrada de Ferro Inglesa e o Governo do Estado em 1890, a qual ainda foi alargada pela Câmara Municipal em 1900, para comunicar o bairro do Bom Retiro com o da Luz (MARTINS 1973, p.240). De acordo com GUARALDO (2002, p.37), em 1895 foram cedidos terrenos do Jardim para a Escola Modelo (hoje Prudente de Moraes em prédio moderno) e em 1900 para o Liceu de Artes e Ofícios (hoje Pinacoteca do Estado), subtrações estas que lhe tiraram a frente para a avenida Tiradentes. Ainda em 1895, segundo KÜHL (1998, p.118 e 121), foram iniciadas as obras da nova estação da Luz, numa área de 7.520 metros quadrados, parte da qual pertencente ao Jardim da Luz, cedida pelo Governo do Estado.

Dessa época ficou o relato do viajante carioca Alfredo Moreira Pinto:

"Fica no largo do Jardim entre a escola Prudente de Moraes e a estação da estrada de ferro inglesa.No alto do portão da entrada lê-se: Presidência do senador Florêncio de Abreu. 1881.".

"Possui diversos pavilhões, repuxos pequenos e um grande no meio de um lago volteado por estatuetas, pontes, ruas largas e ensombradas por denso arvoredo, canteiros, uns gramados e outros com roseiras e flores de jardins particulares, um botequim e uma torre de quatro andares e um observatório" (PINTO, 1979, p.168). 
A partir de 1899, de acordo com GUARALDO (2002, p.40), o Prefeito Antonio Prado tinha interesse pessoal nos assuntos de arborização e ajardinamento, tanto que teria visitado o velho jardim e achado tudo muito provinciano, Após o levantamento de uma planta detalhada, a prefeitura adquiriu em 1901 terrenos particulares junto à rua Ribeiro de Lima e ampliou seu perímetro que ficou com a forma final nesse mesmo ano.

Em seguida foi promovida uma reforma de grandes proporções, acomodando os elementos do traçado antigo na área disponível, transformando-o num ponto de encontro das famílias paulistanas e, principalmente, de moradores próximos. Ali também tocava a banda da Força Pública, contratada junto com as reformas para se apresentar semanalmente (GUARALDO, 2002, p.40).

Como dito acima, o “canudo do Dr. João Teodoro” foi destruído em 1900. Conforme Etzel, apud GUARALDO (2002, p.40-41), foi erguido um pavilhão restaurante, o "quiosque da Bavária", coreto, sanitários, mini-jardim zoológico. Repuxos e lagos novos atestam que o abastecimento de água do jardim, problema antigo que afetava a sua manutenção, já estava regularizado. Ainda foi construída nova residência para o administrador.

Os fornecedores desses novos equipamentos do jardim, todos feitos entre 1900 e 1901, atuaram intensamente em outras obras na cidade: G. Krug construiu a casa do administrador, Maximiliano Hehl o coreto, Julius Ploy os sanitários e os cercados para os animais. As cadeiras em ferro do restaurante foram feitas pela casa Lidgerwood (GUARALDO, 2002, p.38).

Nesta fase, de acordo com JORGE (1988, p.58), com uma área superior a $90.000 \mathrm{~m} 2$, o Jardim da Luz respirava o ar provinciano, misturando fauna e flora, chegando a parecer que tentariam transformá-lo em parque zoológico, tal a variedade de espécies ali recolhidas. Contudo, suplementaram-se recursos e atrativos com a instalação de 135 combustores a gás; reformou-se o tanque, dotando-o com repuxo de jorro superior a 1.000 litros por minuto; em 1908 rebaixaram-se os muros e retirou-se um portão de ferro fundido pela São João de lpanema; a 15 de Novembro 
de 1910, inaugurou-se o busto de Giuseppe Garibaldi com a presença do poeta Olavo Bilac; em 1914 construíram-se passeios com mosaico à portuguesa sob responsabilidade do engenheiro Melo Franco ao preço de 40:887\$000.

O parisiense Paul Adam, citado por BRUNO (1981, p.182) em sua descrição do Jardim da Luz, datada de 1914, dá a entender que à época existiria um rinque de patinação:

\footnotetext{
“Aos domingos, no Jardim da Luz, é agradável ver esse povo enérgico, bem trajado, entregar-se aos prazeres da ginástica e da patinação, por entre o emaranhado das mais belas árvores tropicais, diante dos quiosques onde as mulheres, em sua elegância, saboreiam sorvetes, bebem refrescos. É a vida sadia e limpa."
}

Apenas em 1914 aparece a configuração quadrada atual do parque, no lugar da pentagonal anterior, devido ao prolongamento da rua Prates, que é visto na Planta Geral da Cidade de São Paulo, elaborada pela Comissão Geográfica e Geológica naquele ano (KLIASS, 1993, p.79).

4.7.1.4. Decadência a partir da década de 1930

Na gestão do prefeito Pires do Rio, por volta de 1930, retiraram-se muros e portões, transferindo-se os animais para o Parque da Água Branca, estação experimental da Secretaria da Agricultura. Com isso, o jardim tornou-se amplamente devassável, ponto preferido de marginais à espera de incautos viajantes desembarcados na Estação da Luz. Antigos freqüentadores, famílias com crianças, deixaram de fruir o jardim, acelerando o seu declínio e abandono (JORGE, 1988, p.59).

O último portão sobrevivente do parque, bela peça de ferro forjado, datado de 1901, ficou por décadas abandonado num depósito da prefeitura. Na gestão 
Olavo Setúbal (1975-1979) ele foi salvo do desmanche por iniciativa do então diretor do DEPAVE, Mauro de Moraes Victor, que ordenou a sua recuperação e instalação como portão de entrada principal do Parque do Piqueri, onde se situa até hoje.

Embora o jardim tivesse recebido iluminação elétrica em 1933 (KLIASS, 1993, p.79), sua decadência seguia inexorável. Nas palavras de SANT'ANNA (1939, p. 140):

"Nada lhe resta das antigas glórias, nem da freqüência encantadora dos tempos em que a cidade era mais espiritual e mais ingênua".

O jornal o Estado de São Paulo de 20/01/1971, conforme KLIASS (1993, p.87) noticia que:

"Todo o Jardim da Luz é hoje abandono. Há lixo junto ao muro do Liceu de Artes e Ofícios, há lixo perto da rua Prates, aos montes, mas estranhamente a prefeitura mantém varredores que não tocam nos montes de detritos, apenas levam as folhas de um lado para outro. Um ou outro 'lambelambe' ainda oferece seus serviços de fotógrafo nas beiras do jardim, apenas ali, onde ainda há sorveteiros, algumas crianças brincando, mendigos tristes estendendo a as mãos. Mais para dentro, entretanto, é terreno proibido, é antro de marginais, assaltantes, $\dot{c}$ área de mulheres que assediam mesmo durante o dia os poucos que passam, quase que só os soldados da Polícia Militar que atravessam o jardim para chegar ao quartel, inspirando respeito pela farda..."

4.7.1.5. Revitalização e situação atual

A decadência persiste até 1972, quando o jardim sofreu um processo de revitalização. Foi cercado con grades e recebeu portões (KLIASS, 1993, p.87). A partir de então recebeu a denominação atual de Parque da Luz.

Mesmo assim, nessa mesma década de 70 , teve área concedida a uma entidade de caridade para a instalação do "parque de diversões Shangri-la", o que 
implicou em derrubada de árvores e secamento dos lagos. Com a retirada dessa absurda concessão, o jardim foi novamente limpo e anunciou-se o plantio de duas mil mudas (KLIASS, 1993, p.79.

O parque perdeu mais uma parte de sua frente para a avenida Tiradentes, onde foi construída na década de 70 uma horrenda torre de ventilação do metrô.

O Parque da Luz foi declarado bem cultural tombado pelo CONDEPHAAT (Conselho de Defesa do Patrimônio Histórico, Artístico, Arqueológico e Turístico) pela Resolução 31 de 08/08/1981 e pelo CONPRESP (Conselho Municipal de Preservação do Patrimônio Histórico, Cultural e Ambiental da Cidade de São Paulo) pela Resolução 05/1991 “ex oficio” (SÃO PAULOc)

A partir do ano 2000, a Pinacoteca do Estado passou a utilizar o Parque da Luz como uma extensão de seus espaços, expondo esculturas ao ar livre (MACEDO e SAKATA, 2002, p.172). Entre dezembro de 2006 e julho de 2007 foi restaurada a casa do administrador do parque construida em 1901 no lugar de uma outra mais antiga (MAYUMI, L e SANCHES M., 2008).

Nos dias atuais o Parque da Luz tem área total de $81.758 \mathrm{~m} 2$, entre os quais $48.376 \mathrm{~m} 2$ de vegetação implantada, $29.422 \mathrm{~m} 2$ de caminhos e $892 \mathrm{~m} 2$ de edificações (SÃO PAULOc).

\subsubsection{Problemas observados}

Da longa e acidentada história do Parque da Luz podemos chegar a algumas conclusões.

Ele nunca teve diretrizes nítidas quanto ao seu uso e gestão, ou seja, um manejo definido, seu destino balançando ao sabor dos governos que se sucediam, 
seja no Império ou na República. Iniciado com uma inauguração improvisada, o objetivo do Parque da Luz ficou sempre na obscuridade: deveria ser ele um jardim botânico, com finalidade científica, ou apenas uma área verde destinada ao lazer? Sede de um observatório meteorológico? Parque de diversões ou jardim zoológico? Talvez devesse ser um jardim de esculturas. Até hoje não se pode afirmar que ele tenha uma destinação definida.

Foi murado, gradeado, perdeu as grades e voltou a tê-las. A última retirada das grades, aliás, foi uma verdadeira irresponsabilidade, com conseqüências desastrosas. A partir daí o jardim ficou facilmente devassável e entregue aos marginais. As famílias, temerosas, deixaram de freqüentá-lo, provocando talvez o seu período de maior declínio e abandono, por cerca de quarenta e dois anos.

Teve alguns momentos de apogeu, com investimentos razoáveis e expressiva visitação, separados por longos períodos de decadência, abandono, em que os governantes limitavam-se a implantar grades e serviços de pouca monta, em nada atrativos ao público, demonstrando indiferença diante dos conceitos urbanísticos que já pregavam a necessidade de preservação das áreas verdes. Chegou ao cúmulo de ser transformado em pasto e ter seu abastecimento de água efetuado por canos de papelão!

Perdeu constantemente áreas, tanto que em 1827 o parque tinha em torno de 105 mil metros quadrados de área, dimensões que se mantinham em 1841. Hoje em dia tem pouco menos de 82 mil metros quadrados. Em cento e oitenta e três anos de história, perdeu cerca de 23 mil metros quadrados, ou seja, por volta de um quinto de sua extensão. Houve grandes perdas para o sistema viário, tanto para a implantação de ruas, da ferrovia e de sua estação, como para a ventilação do metrô. Teve também áreas de porte subtraídas para a construção dos prédios da Escola Modelo (Escola Estadual Prudente de Moraes) e do Liceu de Artes e Ofícios (Pinacoteca do Estado). Dessa trajetória fica evidente a ausência de prioridade na preservação das áreas verdes, tratadas pela administração pública como meros espaços livres disponíveis, sempre passiveis de ocupação por outros tipos de empreendimentos. 
4.7.2. Parque Tenente Siqueira Campos (Parque do Trianon: denominação popular)

O empreendedor Joaquim Eugênio de Lima e seus sócios compraram, em 1880 , todos os terrenos da região onde se localiza este parque e projetaram um aristocrático loteamento, cujo eixo organizador era a avenida Paulista, aberta no alto do Morro do Caaguaçu, espigão que dividia as águas dos Rios Pinheiros e Tietê. Nesse loteamento, dois quarteirões cobertos por mata tropical derivada do rebrotamento de árvores cortadas, foram reservados para o então denominado "Parque da Avenida", um parque particular (MACEDO e SAKATA 2002, p. 177)

O projeto, desenvolvido pelo paisagista francês Paul Villon, dotou a área de caminhos sinuosos, cruzando-se em alguns momentos e em outros terminando em recantos, tendo sido inaugurado em 3 de abril de 1892, contendo um pavilhão restaurante e a residência de Villon (GUARALDO, 2002, p.61-62). O parque, que passou a ser chamado de Villon, foi aberto ao público, em 1911, quando a prefeitura o adquiriu do então proprietário Francisco Matarazzo (BARTALINI, 1999, p.52). O belvedere projetado por Ramos de Azevedo, construído nos anos seguintes do outro lado da avenida, recebeu o nome de Trianon e juntamente com o parque, tornou-se símbolo da riqueza da elite paulistana (MACEDO e SAKATA 2002, p.177).

Em 1918 o parque foi remodelado pelo paisagista inglês Barry Parker, sendo construída na entrada uma colunata (REALE, 1982, p.l15). Por muito tempo foi citado nos relatórios oficiais como Parque ou Bosque da Avenida Paulista, passando a ser conhecido posteriormente como Parque Trianon em razão do pavilhão do mesmo nome (KLIASS, 1993, p.141). Finalmente passou a chamar-se oficialmente "Tenente Siqueira Campos", em homenagem a um dos tenentes revolucionários de 1930, por força do Ato 70 de 24/01/1931 (BARTALINI, 1999, p.52).

De 1966 temos una descrição de Gabriel Marques, apud KLIASS (1993, p.146) que demonstra que o Parque Trianon estava sobrevivendo bem, apesar das transformações em seu entorno: 


\begin{abstract}
"E assim é que, hoje, como o encantamento das suas árvores c o gorjeio de scus pássaros, lá está o bucólico parque paulistano a envaidecer a velha cidade de Anchicta, a que 'mais cresce no mundo'(...) Recanto sem dúvida bucólico, de aléias elegantemente sinuosas e com aquela ponte a ligar, em rústico traço de união, os dois pedaços do parque, lá está ele a acolher namorados e a sensibilizar as criaturas que saibam sentir os encantos de uma paisagem poética e realmente viva. Nas pérgulas de entrada estão, em uma, a sensual Aretusa, magistralmente esculpida, em mármore, pelo buril mágico de Leopoldo e Silva; c, na outra, a figura tristonha e simbólica da Nostalgia, magnificamente talhada, também no mármore, pelo cinzel do mesmo saudoso e notável escultor patrício. Quase ao centro, na orla inicial do arvoredo ergue-se imponente em seu volumoso pedestal de granito, a figura máscula de Bartolomeu Bueno da Silva, o destemido Anhangüera. Modelou-a o genial Brisolara. Num dos ângulos da parte interna do bosque se vê, de olhar vivo e músculos retesos, a surgir de um bloco granítico, o atrevido Pã, admiravelmente esculpido por Brecheret".
\end{abstract}

Em 1968 a pérgula (colunata) existente foi retirada e seus caminhos pavimentados com mosaico português. Uma fonte com chafariz foi instalada, mas removida poucos anos depois. A passarela elevada, que conecta as duas partes do parque, originalmente construida na forma de falsa ponte de troncos, foi substituida pela atual de concreto (MACEDO e SAKATA 2002, p.177).

Segundo KLIASS (1993, p. 145), por relatório do prefeito Pires do Rio, de 1927, sabe-se que a partir daquele ano os portões do parque, que se fechavam às 21 horas, passaram a ficar abertos até às 24 horas. Isto significa que o parque era fechado e tinha portões. Porém, ainda de acordo com KLIASS (1993, p.cit.), não há registros de quando foram construídos, nem da data de sua retirada.

O certo é que na década de 1960 a ausência das grades gerava problemas de segurança (KLIASS, 1993, p.151). Mas o problema foi sanado na década de 1970, já que os portões e grades retornaram, de acordo com uma medida que determinou o fechamento de todos os parques da cidade (KLIASS, 1993, p. 145).

O uso atual do parque para descanso e passeios é intenso. Ele tem valor inestimável por sua história, pela possibilidade de isolamento e pela memória da mata 
que já cobriu toda a região. Até hoje, alguns poucos exemplares da rica fauna que se abrigava nessa mata podem ser nele vistos (MACEDO e SAKATA, 2002, p. 177).

O parque é tombado pelo CONDEPHAAT, ata n. 447 e pelo COMPRESP, Resolução n..$^{\circ} 05$ de 05/04/1991 (SÃO PAULOd).

Atualmente a área total compreende $47.132 \mathrm{~m} 2$, divididos $\mathrm{em}: 34.706 \mathrm{~m} 2$ de vegetação natural e implantada, $12.108 \mathrm{~m} 2$ de pisos impermeáveis, $30 \mathrm{~m} 2$ do espelho d'água e $282 \mathrm{~m} 2$ de edificações (SÃO PAULOd).

Por incrivel que seja, embora situado numa região de trânsito extremamente movimentado e sujeita à especulação imobiliária, o Parque Tenente Siqueira Campos, popularmente conhecido por Trianon, entre os estudados neste trabalho, foi o que menos descaracterizações sofreu, tendo apenas perdido a pérgula que emoldurava a sua face voltada para a avenida Paulista, apesar de algumas mudanças no seu desenho e dos problemas de segurança sofridos em razão da falta de gradis.

\subsubsection{Parque da Aclimação}

\subsubsection{Origens}

O Parque da Aclimação foi fundado em terras do antigo Sitio do Tapanhoim, em 1892. Montou-se na região o primeiro zoológico de São Paulo e o primeiro posto zootécnico do Brasil. Foi uma iniciativa particular de um importante personagem da história de São Paulo, o Dr. Carlos José Botelho (DOREA. 1982, p.46). 
Nascido em 1855, na cidade de Piracicaba, e falecido em 1947, em São Paulo, Carlos José Botelho, filho mais velho de Antonio Carlos de Arruda Botelho, Conde do Pinhal, doutorou-se em medicina, pela Academia de Paris, especializandose em cirurgia, em 1880 (DOREA, 1982, p.46).

Retornando ao Brasil, de acordo com DOREA (1982, p.46), iniciou uma carreira notável na área da medicina. Fundou no bairro do Brás, na rua do Gasômetro, o primeiro hospital clínico cirúrgico (particular), conhecido como a "Casa de Saúde do Dr. Botelho". Foi o primeiro diretor clínico da Santa Casa de Misericórdia de São Paulo, um dos fundadores da Sociedade de Medicina e Cirurgia de São Paulo e, em 1895, co-fundador da Policlínica. Esta Policlínica funcionava na esquina da rua São Bento com a rua Direita, atendendo gratuitamente os necessitados com serviços médicos e medicamentos. Nela funcionou oprimeiro serviço de pediatria a partir de 1896, depois da mudança para uma das travessas da Sé, num prédio que Carlos Botelho alugou e ofereceu à instituição, até que se conseguissem recursos próprios e subvenção do governo estadual. Em 1900, a Policlínica já possuía um corpo médico composto de doze profissionais e atendia anualmente a 2.000 casos.

Abandonando a medicina, conforme DOREA (1982, p.46-48), Carlos Botelho passou a dedicar-se à política è à agropecuária. Foi vereador da capital, secretário e senador estadual. No quadriêniol 1904-1908, sob a presidência de Jorge Tibiriçá, Carlos Botelho assumiu a pasta da secretária de agricultura, viação e obras públicas.

Este cargo permitiu a Botelho grandes realizações. Uma delas foi dar inicio à imigração japonesa no Brasil, que se iniciou no dia 18 de junho de 1908, no porto de Santos, quando atracava a vapor Kasato Maru trazendo a primeira leva com 165 familias num total de 781 pessoas (DOREA, 1982, p.47)

Com pensamento voltado para o futuro, Carlos Botelho não se deixara impressionar pela febre do café que dominava os paulistas. Assim, buscou a diversificação da lavoura pela introdução da cultura do arroz por irrigação, 
especialmente no vale do Paraíba; incentivou a cultura do algodão e da alfafa; implantou a Escola Superior de Agricultura Luiz de Queiroz em Piracicaba; organizou a primeira estatística agrícola e zootécnica do Estado; construiu os três primeiros silos para forragem - o primeiro, no posto zootécnico da Mooca; o segundo, no Jardim da Aclimação; e o terceiro, na sua fazenda de Dourados -; realizou as primeiras exposições regionais e estaduais de animais (DOREA, 1982, p.48).

No ramo da pecuária, os planos do ex-médico tinham um objetivo: transformar as terras incultas do Município e do Estado de São Paulo em campos criatónios. Animava-o uma crença inabalável na existência de locais propícios à criação de gado leiteiro. Sua primeira medida foi o aproveitamento do gado crioulo e caracu, criando postos de seleção e aperfeiçoamento das espécies bovinas em todo interior do Estado (DOREA, 1982, p.48).

No setor de obras públicas, talvez seu feito mais notável tenha sido a implantação do plano de saneamento de Santos, efetuado pelo engenheiro Saturnino de Brito, com a construção da rede de canais iniciada em 1905, sendo inaugurado o canal um já em 1907. Esta rede que até hoje é destaque naquela cidade drenou os terrenos pantanosos da região, livrando a cidade do flagelo da febre amarela (UMA GUERRA PELOS CANAIS SANTISTAS).

Quando retornou de seus estudos em Paris em 1880, Carlos Botelho trouxe a idéia de implementar um parque inspirado no "Jardin d'Acclimatation", situado no "Bois de Boulogne", que ele freqüentava nas horas de lazer (DOREA, 1982 p.49).

O "Jardin d'Acclimatation", e não "d'Acclimation" como aparece em algumas fontes, foi idealizado pela "Societé Imperiale Zoologique d'Acclimatation" fundada em 1854 (hoje denominada Societé Nationale de Protection de La Nature), a qual tinha entre suas finalidades a introdução e aclimatação da fauna e flora exótica para diversão dos visitantes e eventual exploração agrícola ou comercial. Inaugurado em 06/08/1860, o “Jardin d'Acclimatation", em seus primeiros anos, atuava como um jardim de lazer, misturando natureza, flora luxuriante e animais exóticos. Em 
1866 havia 110 mil animais no parque. Também havia uma espécie de exposição etnográfica, onde os visitantes podiam observar o modo de vida de povos "exóticos", como indígenas norte-americanos, nativos africanos ou lapões. Esse jardim manteve tais características até o final do século XIX, época em que foi conhecido por Carlos Botelho. Atualmente é um parque voltado para o lazer e educação infantil (JARDIN D’ACCLIMATATION).

Para tanto, de início Carlos Botelho tentou fazê-lo com participação do Estado, que adquiriria os campos que existiam no vale do Sítio do Tapanhoin - além da Liberdade e da Glória. Sem êxito, ele mesmo comprou toda a região, que transformaria depois em granja leiteira, bosque, parque de diversões e zoológico. Parte da propriedade era particular e parte aberta ao público (DOREA, 1993, p.49-50).

\subsubsection{Período privado}

Com a dedicação de seu criador, em pouco tempo o Jardim, também denominado Parque da Aclimação, tornou-se ponto de visitação obrigatória para todos os pecuaristas do Estado de São Paulo e até do Brasil. E também ponto turístico procurado pelas famílias paulistanas, aos domingos e feriados, que a ele eram atraídas pelo ar puro que se respirava e por suas diversões. Além da granja leiteira, onde se tomava leite quente tirado na hora, havia o zoológico, o parque e o lago formado pelas águas represadas do córrego, também chamado Aclimação (DOREA, 1993, p.49-50).

O logradouro não representava simples amostra de animais exóticos, ou simples local de entretenimento, mas também, um perfeito e completo parque experimental zootécnico e botânico, e um laboratório de pesquisas cientificas especializadas no estudo do câncer (DOREA, 1993, p.50). 
Segundo DOREA (1982, p.53), a década de 1920 foi o apogeu do Parque da Aclimação. À época, o aceso ao jardim se fazia por dois monumentais portões de ferro fundido. O principal ficava voltado para a avenida da Aclimação e o outro para a rua Muniz de Souza. Este era usado de preferência pelos moradores do Cambuci. O preço do ingresso era de 300 réis (individual) e de 3.000 réis para aqueles que desejassem entrar com seus automóveis.

Nessa época, a rua Muniz de Souza ainda não se comunicava com a avenida da Aclimação como hoje, comunicação esta aberta em área originalmente do parque. Conforme DOREA (1982, p.53), o jardim abrangia toda aquela região até atingir a parte montanhosa, onde está localizado o largo General Polidoro, e adjacências.

Ao entrar pelo portão da avenida, o visitante logo se deslumbrava com uma larga e bem cuidada alameda, sombreada por árvores frondosas, que circundavam o lago em toda a sua extensão, numa distância de aproximadamente dois quilômetros. Essa alameda estava dividida em duas partes: na maior ficavam as diversões, o bosque e a "vacaria"; na outra estava instalado o zoológico (DOREA, 1982, p.53).

Na primeira parte havia salão de baile, onde uma banda de música executava as danças da época e rinque de patinação. A seguir, localizadas, uma após a outra, de frente para o lago, numerosas barracas apresentavam uma série de atrações: tiro ao alvo, tiro de bolas quebra-pires, jogo de argolas, carrossel de sorteios e outros vários jogos, com prêmios e prendas que iam desde pacotes de balas ou de chocolates até cobiçadas bonecas. Também havia uma barraca com aquário que apresentava numerosos e raros espécimes (DOREA, 1982, p.54).

A barraca que o público mais procurava era aquela onde, por um sistema de fotografias contínuas, movidas por um engenhoso mecanismo elétrico, o espectador, ao olhar pelo visor especial, colocado no alto da caixa, tinha a impressão de estar assistindo a um espetáculo cinematográfico. E isso tudo custava 100 réis - o 
popular tostão - que deveria ser introduzido numa fenda da máquina, a fim de coloca-lá em funcionamento (DOREA, 1982, p.54-55).

A “cremérie"(leiteria) oferecia produtos de laticínios de primeira qualidade, obtidos de vacas da mais alta linhagem, selecionadas de raças bem apuradas e que faziam parte dos estábulos da "vacaria" do jardim (DOREA, 1982, p.55).

Junto à margem do lago havia o embarcadouro, onde botes de aluguel permitiam um passeio de barco. A parte do lago onde existia uma amurada, estava reservada ao parque de diversões e à "terrasse". Enquanto no parque de diversões os mais jovens se entretinham na roda-gigante, no carrossel, ou em outros brinquedos, os adeptos da ginástica exibiam as suas veleidades acrobáticas na barra fixa, na paralela, pendurados nas argolas ou balançando no trapézio (DOREA, 1982, p.55).

$\mathrm{Na}$ "terrasse", os mais idosos sentavam-se às mesas, protegidas por grandes e coloridos guarda-sóis, onde, saboreando refrigerantes, sanduíches ou sorvetes, contemplavam os barcos na placidez do lago. Ao fundo, o cenário da vasta plantação de eucaliptos, a "vacaria" e o silo cilíndrico, pintado de branco - talvez o primeiro da América do Sul, construído para armazenamento racional de forragens (DOREA, 1982, p.55).

E, enquanto isso acontecia, as crianças, no jardim fronteiro à "terrasse"; brincavam de roda e outros jogos, ou então passeavam em minúsculas carruagens puxadas por asnos, pôneis ou emas (DOREA, 1982, p.55)

O zoológico foi a parte que mais notabilizou o jardim. A alameda que lhe dava entrada era protegida por duas cancelas, uma em cada extremidade. Para se visitar os animais pagava-se uma taxa suplementar. E lá se encontrava todo o tipo de animal exótico ou nativo (DOREA, 1982, p.55)

A existência de um zoológico como era o da Aclimação, com uma fauna tão variada e principalmente, com grande quantidade de macacos, foi propicia à criação de um laboratório de pesquisas, na sede da Sociedade Hípica Paulista, que 
também funcionava dentro do parque. Sua fundação se deve ao próprio Carlos Botelho. O laboratório foi ampliado, transformando-se no Instituto Botelho de Cancerologia, por obra de Carlos Botelho Júnior, autor da "reação Botelho". O Instituto encontrou no zoológico vasto campo para investigações sobre tumores malignos espontâneos dos animais (DOREA, 1982, p.55).

Já na década de 30, a família Botelho iniciou o retalhamento das terras de propriedade privada adjacentes ao parque. Alguns anos antes, Carlos Botelho transferira tudo para os filhos. Estes à medida que vendiam lotes para estranhos, concomitantemente conservavam alguns, que distribuíram entre os netos do fundador. Iniciaram-se as construções e a região começou a adquirir nova feição. (DOREA, 1982, p.57-58).

\subsubsection{Período público}

O parque já não possuía o mesmo esplendor dos anos 20. Em 16 de janeiro de 1939 a prefeitura de São Paulo comprou-o da família Botelho, incorporando-o ao patrimônio da cidade, a fim de evitar seu loteamento. O imóvel era formado por duas glebas com um total de $182.000 \mathrm{~m} 2$ e incluía todas as benfeitorias móveis e semoventes lá existentes, inclusive os animais do jardim zoológico, tendo sido adquirido pelo Município pelo valor total de 2.850 contos de réis (DOREA, 1982, p.99-100).

Segundo a escritura pública de venda e compra transcrita em parte por DOREA (1982, p.100), o parque tinha as seguintes divisas à época:

“(...) a primeira área divide pela frente com uma rua nova ainda não oficializada, recentemente aberta pelos outorgantes e que liga a Avenida da Aclimação à Rua Muniz de Souza, na extensão de, mais ou menos, $301,50 \mathrm{~m}$; pelo lado direito, por muro e cerca, com sucessores do Banco Melhoramentos de São Paulo; pelo lado esquerdo com a Rua 
Topázio, com um córrego e com sucessores de Francisco Justino, também por muros e cercas; pelos fundos com a Rua Brás Cubas, e por cerca, novamente com sucessores de Francisco Justino e do Banco Melhoramentos de São Paulo; a segunda área confina, pela frente, com a Rua Brás Cubas, pelos lados e pelos fundos, por cerca, novamente com sucessores de Francisco Justino, terrenos esses conhecidos por Morro da Aclimação (...)".

De acordo com KLIASS (1993, p.157), não existe documentação que permita dimensionar a área efetivamente ocupada pelo parque durante seu auge, na década de 1920. Mas certamente deveria ser maior que a área de $182.000 \mathrm{~m} 2$ constante da escritura de compra e venda de 1939.

Sabemos, no entanto, que o parque tem hoje $118.787 \mathrm{~m} 2$ (SECRETARIA DO VERDE E DO MEIO AMBIENTE), o que significa uma redução de $63.213 \mathrm{~m} 2$, ou cerca de quarenta por cento de sua extensão, ocorrida, o que é mais grave, quando a área já era de domínio público. E pensar que a prefeitura adquiriu o Parque da Aclimação dos herdeiros de Carlos Botelho visando impedir o seu desaparecimento!

Apesar da imprecisão das divisas contidas na escritura pública, podemos identificar alguns logradouros. A denominada "rua nova ainda não oficializada" é a continuação da rua Muniz de Souza até a avenida da Aclimação. Isto significa que a parte montanhosa, onde está o largo General Polidoro e adjacências já não mais pertencia ao parque. Aliás, a praça Jorge Cury, com seu mirante, ao que tudo indica, é um remanescente da fase em que o parque era particular.

Observando-se ainda a escritura, não é possível identificar a rua Pedra Azul, que ou não existia ou era a "rua aberta em terrenos dos sucessores de Francisco Justino". Mas fica evidente que as ruas Topázio e Brás Cubas formavam divisas do parque. Assim, sendo, pode-se concluir que o quarteirão formado pelas atuais ruas Topázio, Brás Cubas, Ametista e Pedra Azul integrava a área do parque em 1939. Igualmente a pequena quadra formada pelas atuais ruas Brás Cubas, Ametista, Pedra Azul e Dr. Paulo Dias.

Esta presunção é reforçada pelo fato de que a quadra maior ainda apresenta um maciço arbóreo formado por eucaliptos, muito semelhante àqueles que 
se encontram no interior atual do Parque da Aclimação. Esse terreno ainda é quase todo ocupado por bens de uso institucional, quais sejam, a Escola Municipal Hellen Keller, um viveiro de plantas munícipal, atualmente desativado e uma base da Companhia de Engenharia de Tráfego. A quadra menor é toda ocupada pela Escola Municipal Brig. Faria Lima. São áreas do parque que, para variar, foram disponibilizadas pelo poder publico municipal para outros usos, sem maiores considerações quanto à preservação ambiental. Mesmo parte da área interna do parque foi igualmente perdida, no caso para o prédio da Biblioteca Municipal Ophélia França.

O leito da rua Pedra Azul, no trecho que contorna a atual cerca, seccionou a área original adquirida pelo poder público quase ao meio, de modo a deixar de um lado o atual parque e de outro a parte descaracterizada. Também as rotatórias denominadas praças Alex Freua Neto e Prof. Belmiro Nascimento Martino, pela sua conformação, eram áreas integrantes do perímetro do parque em 1939.

A aquisição pela municipalidade praticamente nada significou. Foi-se acentuando o declínio que o parque já vinha sofrendo na década de 1930. E começou a total decadência: o mato invadiu os gramados, a água do lago ficou poluída, o parque de diversões foi destruido e os animais foram retirados (DOREA, 1982, p.100).

Em 1955 surgiu um projeto ambicioso demais para ser passível de realização. Era uma tentativa de restauração do antigo programa, pois incluía nos seus objetivos a implantação uma granja leiteira, de propriedade municipal, para fornecer leite às crianças que a visitassem (uma espécie de fazenda numa área tão próxima do centro da cidade), charretes, cabras e ovelhas espalhadas por todo parque, um novo "playground", um restaurante-abrigo e um velódromo, para as crianças andarem de bicicleta, livres do perigo dos automóveis (DOREA, 1982, p.101).

Esse projeto, excessivamente ambicioso para a época, teve de ser abandonado e um outro mais simples o substituiu, nas gestões dos prefeitos Jânio Quadros e William Salem. As alamedas foram asfaltadas e a iluminação tornou-se 
abundante; foi construída uma concha acústica, cuja inauguração solene se deu a 9 de maio de 1955 (DOREA, 1982, p.101).

O Diário da Noite de 04/11/1955, apud DOREA (1982, p101), noticiava a recuperação do parque após dezesseis anos de abandono:

\begin{abstract}
“Agora tudo ali é festa. Num gramado amplo jogam futebol matutino jovens das redondezas com voluntária torcida não se sabe saída de onde. Há gente miúda de todas as idades nas balanças, nos automóveis, nos divertimentos do parque de diversōes que funciona à noite, domingos e feriados. No lago passam os pequenos barcos a gasolina e também um grande barco colorido que, em relação aos outros, lembra um navio capitânia, um lento e majestoso couraçado. É o coletivo da flotilha naval. $O$ sol desce do alto, numa cachoeira trêmula de luz. As águas arrepiam-se ao contato das quilhas que deixam atrás de si oblíquas marolas que vão morrer pelas margens relvadas. Há alegria por toda parte".
\end{abstract}

Em 09 de agosto de 1956, noticiava a Folha da Noite que a prefeitura estava tentando fazer reviver o grande projeto que fora abandonado, acrescentando ao parque um recanto com choupanas, estábulos, ilhas e pontes artificiais sobre o lago; um local destinado à educação física e outro para a construção de um pequeno teatro. Porém, nada disso foi feito (apud DOREA, 1982, p.101).

Não tardaria nova fase de declínio, a ponto de, conforme DOREA (1982, p.102), o jornal O Estado de São Paulo de 20/08/1969 noticiar categoricamente ao público:

\footnotetext{
“ACLIMAÇÃO - O PERIGO!”

“Não vá ao Parque da Aclimação, nem durante o dia, muito menos à noite. Esse Parque não foi remodelado pela Prefeitura e as más intenções se escondem por detrás da vegetação espessa ou da escuridão quase total que marcam o Parque da Aclimação!"
}

Esta situação se prolongaria até a administração Figueiredo Ferraz (1971 1973), quando o parque recebeu finalmente a necessária recuperação. Em primeiro lugar foram feitas as obras, de limpeza nas alamedas e canteiros, removendo o mato a fim de que fosse viável o andamento da reforma propriamente dita. Em seguida passou-se à restauração das obras já existentes: o antigo ancoradouro, a concha 
acústica, a pista de bocha, a praça esportiva, os canteiros e as alamedas. Na etapa seguinte o jardim foi cercado por grades altas em toda a extensão, a entrada pelos três portões de acesso passou a ser fiscalizada por policiais e inaugurou-se a iluminação de mercúrio. As alamedas foram pavimentadas, imensas áreas foram ajardinadas, novos bancos e passeios foram construídos, como também uma quadra de basquete (DOREA, 1982, p.102-103).

Em 1983, mais um atentado contra o Parque da Aclimação: o então prefeito Antônio Salim Curiati tentou doar uma área de $2.500 \mathrm{~m} 2$, onde se situam as quadras poliesportivas, ao Colégio Anglo-Latino. Esse absurdo levou ao pedido de demissão do então secretário municipal de serviços e obras, Paulo Gomes Machado. O clamor popular foi tamanho que o prefeito teve de voltar atrás (CASTRO, 1986, p.06-07).

Tendo em vista o abandono do parque e buscando impedir novas reduções de sua área, em 30/04/1986, em cerimônia ocorrida na Escola Municipal Brig. Faria Lima, foi pedido o seu tombamento ao CONDEPHAAT pela Associação de Defesa do Parque da Aclimação, com apoio da Subcomissão de Meio Ambiente da OAB/SP e da entidade ecológica Oikos -União dos Defensores da Terra, acompanhado por um abaixo-assinado com quatro mil assinaturas (CASTRO, 1986, p.06-07).

O tombamento foi efetuado pelo CONDEPHAAT através da Resolução $\mathrm{n}^{\circ} 042$ de 05/10/1986, tendo sido também tombado "ex-officio"pelo CONPRESP por meio da Resolução nº 05 de 05/04/1991 (SÃO PAULOa).

Aquele mesmo Colégio Anglo-Latino viria a ser desativado e seu terreno, que divide muros com o Parque da Aclimação, arrematado para a construção de edificios pela Camargo Correa Desenvolvimento Imobiliário. Em julho de 2007 o CONPRESP regulamentou o entorno do parque, determinando a altura máxima de 10 metros para edifícios ao redor da área verde. Com isso a construtora poderia construir apenas edificações de até três andares, o que não permitiria o atrativo previsto em seu projeto inicial: a esplêndida vista do parque (SP desapropria terreno para o Parque da Aclimação, 2008). 
Desde que iniciou o projeto imobiliário, a Camargo Correa enfrentou oposição dos moradores da região. A construtora chegou a demolir parte das edificações existentes no terreno, mas foi impedida pela Subprefeitura da Sé, que embargou a demolição (idem).

Finalmente, em 25/04/2008, o prefeito Gilberto Kassab sancionou o Projeto de Lei 561/07, do vereador Dalton Silvano, que se tornou então a Lei 14.719 de 25/04/2008 que declarou de utilidade pública para desapropriação o terreno do antigo Colégio Anglo-Latino, a ser incorporado ao Parque da Aclimação (CONPRESP).

$\mathrm{O}$ parque tem atualmente uma área de $118.787 \mathrm{~m} 2$, dos quais $65.856 \mathrm{~m} 2$ são vegetação implantada; $120 \mathrm{~m} 2$ de pisos permeáveis; $18.110 \mathrm{~m} 2$ de pisos impermeáveis; $33.380 \mathrm{~m} 2$ de lago e $1.321 \mathrm{~m} 2$ de edificações (SÃO PAULOa). Graças à desapropriação acima referida, ele receberá, depois de setenta anos, seu primeiro acréscimo: 3.345 m2 (SP desapropria terreno para o Parque da Aclimação, 2008).

\subsubsection{Problemas observados}

Como se pode ver, o Parque da Aclimação passou por duas fases. Na primeira fase, a privada, de 1892 até 1939, ele foi um misto de bosque, parque de diversões, jardim zoológico e granja leiteira. Era cercado e seus visitantes pagavam ingresso. Teve seu apogeu na década de 1920, com visitação intensa, época em que seus proprietários tinham interesse em mantê-lo bem cuidado. Findo este interesse, o parque entra em declinio e os proprietários iniciam o loteamento da área, tratada como um terreno privado qualquer, a ser objeto de especulação imobiliária. Seu destino parecia ser o total desaparecimento, semelhante ao ocorrido com o Parque Antártica, o Bosque da Saúde e outros congêneres de domínio particular. Neste 
instante surge um diferencial: o poder público municipal adquiriu a área remanescente em 1939, com a finalidade de impedir sua destruição.

Inicia-se então a segunda fase, a pública, que começa em 1939 e dura até hoje. Ao contrário do previsto, ao invés de zelar pela preservação, por muitos anos a municipalidade disporá do parque como se fosse uma área livre qualquer, a ponto dele ter perdido cerca de quarenta por cento de sua extensão para o sistema viário e usos institucionais, como escolas, viveiro, quartel e biblioteca. Esse processo de destruição somente é freado pela participação da comunidade do bairro, que na década de 1980 impede o desmembramento da área das quadras esportivas e obtém o tombamento do Parque da Aclimação.

Nessa fase pública o parque ressente-se pela ausência de um plano diretor coerente. É o quadro, por assim dizer, normal dos parques urbanos paulistanos: ausência de manejo definido; períodos de abandono e recuperação alternados, ao talante das administrações municipais; reduções constantes de área patrocinadas pelo próprio poder público.

Assim, após a aquisição dos herdeiros de Carlos Botelho, a municipalidade não soube o que fazer com ele. O parque passa nada menos que dezesseis anos totalmente abandonado. Surgem dois projetos de recuperação, tentativas frustradas de restaurar o seu programa original, que terminaram inviabilizados por falta de recursos. Na década de 1950 foi finalmente implementado um programa bem mais modesto, de bosque voltado ao lazer. O parque passa a ser efetivamente fruído como tal pela população.

Entretanto, passados apenas quinze anos, em meados da década de 1960, o parque já estava novamente decaído. O descaso na manutenção, ausência de vigilância e falta de cerca protetora, resultavam num local abandonado, perigoso, evitado pela população. Apenas na década de 1970 ele é restaurado pela prefeitura e cercado por grades, voltando a servir como área de lazer, principalmente para a população da vizinhança, que a partir da década de 1980 , no exercício de seus 
direitos de cidadania, passa a exigir do poder público municipal a efetiva preservação do parque, de que resultou o seu tombamento.

E graças também à participação popular que o Parque da Aclimação receberá seu primeiro acréscimo em setenta anos de história. Exatamente o terreno anteriormente utilizado pelo seu antigo algoz, o Colégio Anglo-Latino.

4.7.4. Parque do Ibirapuera

\subsubsection{Origens}

As áreas do atual Parque do Ibirapuera caracterizavam-se fundamentalmente por servirem de pastagens e descanso de gado desde o início da colonização. Os bairros situados no então denominado distrito sul da Sé, entre os quais a área do Ibirapuera, em função da proximidade com a estrada de acesso ao litoral, receberam constantes melhoramentos, até o período da expansão cafeeira para o oeste (OLIVEIRA, 2003, p.30). Ibirapuera significa "pau podre, árvore velha, apodrecida" (SÃO PAULOb).

Tais terras, em processo judicial do início do século XX, foram identificadas como devolutas, que desde 1660 eram bens públicos municipais (idem, p.36).

Esta região sul sofrerá no século XIX uma espécie de estagnação no processo de urbanização, embora tenham sido concedidas datas de terras pela Câmara Municipal, especialmente a partir de 1880, na estrada do Vergueiro, no Caaguaçu, no Telégrafo e na estrada de Santo Amaro (TORRES, 1972, p.57). 
Até o início do século XX, segundo OLIVEIRA (2003, p.32), as ocupações por particulares da região caracterizavam-se pelas atividades rurais, como serviços de apoio e precárias construções de suporte aos condutores de gado e animais. Sequer se aventava a hipótese de criar um grande parque.

Essa função rural, especialmente de pasto, foi reforçada pela implantação do matadouro municipal em 1887, ao lado do qual foi pouco tempo depois construído um curtume, que tingia de sangue o córrego do Sapateiro (MASAROLO, 1971 , p.41 e 43). O prédio do matadouro municipal, existente até hoje, é bem protegido pelo tombamento estadual e municipal, sendo utilizado como sede da Cinemateca Brasileira, no largo Senador Raul Cardoso. Segundo ainda MASAROLO (1971, p.43), no local do curtume existe uma escola do SENAI, situada na atual rua Gandavo.

Tanto se buscava preservar a função rural desse espaço que, em 29/11/1887, o vereador Vicente Ferreira da Silva apresentou indicação no sentido de que a Câmara Municipal "represente ao Ministério da Agricultura, por meio do Império, que não convém a continuação da venda de terras públicas, na várzea de Santo Amaro, por destinarem-se tais terras ao uso comum dos moradores do município e à apascentação do gado, de corte diário" (SÃO PAULO, 1907, p.339).

De acordo com TORRES (1977, p.97), em 1914 o Estado de São Paulo concluiria a discriminação dos terrenos situados nos bairros do Matadouro e da Saúde, fixando a linha que separava a zona municipal da estadual. Assim, pelo Decreto Estadual 2.669 de 17/05/1916, foram incorporados ao patrimônio municipal os terrenos devolutos contidos na área do Ibirapuera, no montante de aproximadamente 1.500 .000 metros quadrados.

Segundo o relatório apresentado pelo Dr. João Otaviano Pereira de Lima ao prefeito Pires do Rio (1927-1928), esse imóvel à época tinha o seguinte perímetro (apud TORRES, 1977, p.97): 
"cuja linha divisória começa no cruzamento da rua Nova com o córrego do Sapateiro,onde existe um valo; segue esse valo até a estrada velha de Santo Amaro; por esta, na direção sul, até o marco cravado na beira da estrada, junto à chácara do coronel Piedade; desse ponto, acompanha a linha perimétrica do círculo com raio de seis quilômetros, até o Ribeirão Uberaba, segue por este até seu afluente, córrego das Éguas, até alcançar a Rua Nova, e, por esta, na direção norte, até o ponto inicial, confrontando, ao Norte, com a invernada do Corpo dos Bombeiros, a Este, com a Vila Clementino, ao Sul, com a Cia. Territorial Paulista, Antonio de Andrade e outros, a Oeste, com Dr. Bento de Camargo e outros".

No início do século XX já surgia a consciência da necessidade de se implantar parques públicos em São Paulo, inclusive em face do retalhamento dos parques particulares, que ocorrido à época, havia deixado São Paulo muito pobre em áreas verdes. Em 1924, parecer conjunto das Comissões de Justiça, Obras, Finanças e Higiene da Câmara Municipal já constatava que todas as grandes capitais possuíam os seus parques e notáveis jardins e que São Paulo, porém, tendo em conta a valorização crescente dos terrenos, nada tinha para ser utilizado para esse fim, já que tudo havia sido dividido em lotes; haja vista o Bosque da Saúde e o Parque do Jabaquara (SÃO PAULO, 1924, p.634).

O esgotamento das alternativas, considerando a dificuldade de adquirir os bosques particulares e a destinação da várzea do Tietê para o canal e as avenidas marginais, fez com que só restasse para o Município a opção do Ibirapuera (CAMPOS, 2002, p.311).

Naquela época era considerado normal que a prefeitura loteasse glebas municipais $\mathrm{e}$ as vendesse a particulares, como faziam tantos especuladores imobiliários. Um exemplo foi o loteamento de terrenos municipais no início do século XX, que originou a Vila Clementino, que segundo CAMPOS (2002, p.311) é um "loteamento ortogonal e sem atrativos". Realmente, o descaso pelas áreas verdes era tamanho, que esse bairro, embora loteado pelo poder público municipal, é praticamente todo impermeabilizado. 
Assim, pela Lei 2.122, de 16/03/1918, foi autorizado o loteamento das terras municipais do Ibirapuera, a ser realizado pela própria prefeitura, com objetivo de vender os lotes em concorrência pública (CAMPOS, 2002, p.311). Esse loteamento corresponde ao atual Jardim Lusitânia (ANDRADE). Por outro lado, em 1919, numa proposta de cunho inovador para a época e de aparente alcance social, embora pouco ecológica, a Câmara Municipal sugeria que a gleba do Ibirapuera fosse objeto de concessão gratuita a empreendedores que edificassem casas operárias (SÃO PAULO, 1919, p.416).

Até os edis que se destacavam pela defesa da criação de áreas verdes eram favoráveis à venda do Ibirapuera. Em 1921, projeto de lei apresentado pelo vereador Paiva Meira, o mesmo que em 1923 defenderia a aquisição do Parque da Aclimação pela prefeitura (SÃO PAULO, 1923, p.586), propunha a implantação no Ibirapuera de conjunto residencial traçado "com todos os elementos da estética urbanista moderna" (SÃO PAULO, 1921, p.487-488). Luciano Gualberto, que havia apresentado em 1920 projeto de lei declarando de utilidade pública as matas do Bosque da Saúde com o objetivo de transformá-las em parque público (CAMPOS, 2002, p.309), em 1925 propôs destinar 2 mil contos de réis anuais para a construção de casas operárias na gleba do Ibirapuera (SÃO PAULO, 1925, p.1032).

Como não seria de se estranhar, defensores de interesses corporativistas também desejavam o seu quinhão da várzea do lbirapuera. Em 1923, um trecho de 360 mil metros quadrados no Ibirapuera era objeto de plano de arruamento e loteamento destinado aos funcionários e operários da prefeitura, tendo a Câmara inclusive aprovado um anteprojeto de arruamento, constante de planta enviada pela municipalidade (CAMPOS, 2002, p.312). Portanto o Executivo e o Legislativo municipal estavam aparentemente unidos em prol do funcionalismo e pelo desmantelamento da várzea do Ibirapuera. Parece até um milagre que ela tenha sobrevivido a interesses tão poderosos.

Felizmente os projetos de implantação de casas operárias, econômicas e de funcionários não chegaram a se concretizar. Porém, conforme CAMPOS (2002, p.312), em meados da década de 1920 cerca de 450 mil metros quadrados das terras 
municipais do Ibirapuera já haviam sido vendidos mediante concorrência pública. Restava cerca de um milhão e meio de metros quadrados, confinantes com uma gleba estadual, a Invernada dos Bombeiros.

Por esse tempo, na descrição de MASAROLO (1971, p.76-77), o futuro Parque do Ibirapuera tinha a aparência de um terreno plano, enxameado de montículos de cupins, com capim ralo, um retrato fiel de campina. Nas partes mais úmidas, havia pequenos lagos rasos, feitos em tempos antigos para matar a sede do gado, que pareciam pontos prateados e quebravam a monotonia da visão. Quem estivesse na antiga rua do Curtume (atual rua Tangará), próximo ao atual Instituto Biológico, veria ao longe, junto ao córrego do Sapateiro, uma fileira de pequenos eucaliptos que delimitavam aquele imenso terreno.

Continua MASAROLO (1971, p.77) explicando que atrás dos referidos eucaliptos havia moradas de chacareiros e criação de gado leiteiro. Pelo lado norte essas terras faziam divisa com áreas estaduais, separadas por um pequeno córrego tributário do Sapateiro, as quais eram chamadas “Invernada dos Bombeiros” e com a rua Abílio Soares que então desembocava na av. Brigadeiro Luís Antonio, de onde saíam os caminhos de Pinheiros e Santo Amaro. Pelo lado sul terminava esse grande campo na antiga rua França Pinto (atual avenida IV Centenário), que nesse trecho era desabitada.

Como se pode observar dessa descrição, embora de grande porte e quase despovoada, a área do Ibirapuera não possuía maiores atrativos paisagísticos nem vegetação significativa.

No início da administração Pires do Rio, em 1926, ocorreu uma reviravolta no tratamento da questão: os terrenos municipais do Ibirapuera seriam transformados num grande parque urbano. Mesmo desprovida de interesse paisagistico e vegetação relevante, a área estava disponível, não requeria desapropriação e poderia ser ampliada pela incorporação da Invernada dos Bombeiros e pela reaquisição dos trechos já vendidos. Foi nesse sentido o parecer da 
Câmara Municipal quando a prefeitura solicitou autorização para ajardinar a área em junho de 1926 (SÃO PAULO, 1926, p.451-453).

No relatório que encaminhou à Câmara sobre o exercício de 1927, são os seguintes os comentários tecidos a respeito do futuro Parque do Ibirapuera pelo prefeito Pires do Rio (RIO, 1928, p.32-33):

"Contigua aos terrenos da Invernada dos Bombeiros, propriedade do Governo do Estado, possui a Municipalidade uma considerável extensão, por onde correm as avenidas França Pinto e Rodrigues Alves e que, além desta via ocupada pelos trilhos da linha de bondes de Santo Amaro, constitui a zona Vila Clementino e os terrenos do Matadouro Municipal".

“Já o Municipio vendeu grande parte de suas terras na Vila Clementino, possui, entretanto, quase toda a superficie que vai dar da avenida França Pinto ao córrego do Sapateiro. Por permuta com o Governo do Estado, adquiriu a zona compreendida entre esse córrego e o do Caaguaçu, parte maior da Invernada dos Bombeiros. Por compra, adquiriu o terreno situado entre esse córrego e o fim da rua Abílio Soares".

"Sobre toda essa vasta extensão, que mede perto de 2.000.000 de metros quadrados, estamos construindo um grande parque, futuro logradouro de valor incomparável para a cidade de São Paulo".

"Uma audaciosa tentativa de esbulho, fundada em documentos falsificados retardou a obra que estamos realizando; mas, já começamos o amanho das terras para o parque e o plantio de árvores já foi iniciado".

“A defesa judiciária da Municipalidade prestes será concluída e os criminosos punidos por lei. A ação judiciária, como dissemos, retardou mas não impediu a obra que temos realizado para o preparo do terreno destinado ao grande parque; dispendeu a Municipalidade para aquisição de mais 182.000 metros quadrados compreendidos pela rua Abilio Soares, rua Curitiba e córrego Caaguaçu, 650:000\$000 ou menos de $4 \$ 000$ a metro quadrado".

"Esse parque, com parte de 2.000 .000 de metros quadrados, virá triplicar a superficie dos jardins da nossa magnífica cidade-capital. Temos agora, em São Paulo, apenas 926.839 metros quadrados de parques e jardins para uso de uma população de quase 1.000 .000 de habitantes. Com o parque 
de Ibirapuera triplicaremos a superficie atual. Mas ainda será pouco".

Assim que a notícia da implantação do novo parque se espalhou, especuladores trataram de requerer o reconhecimento de supostos títulos de propriedade sobre a área. O prefeito Pires do Rio determinou uma resposta enérgica a cargo da Procuradoria do Município, visando garantir os direitos da prefeitura sobre as áreas envolvidas, além de expulsar ocupantes ilegais já instalados no local. Em novembro de 1928, o Tribunal de Justiça de São Paulo deu ganho de causa à prefeitura, confirmando seu domínio sobre o Ibirapuera (CAMPOS, 2002, p.313).

Ao mesmo tempo, o Município adquiriu alguns terrenos particulares visando completar a área do parque. Foi também efetivada uma permuta com o Governo do Estado. Em troca da área da antiga Escola de Pomologia, na Água Branca (onde atualmente está implantado o Parque Fernando Costa), o Estado repassou ao Município uma parte da Invernada dos Bombeiros, totalizando dois milhões de metros quadrados para o Parque do Ibirapuera (CAMPOS, 2002, p.313-314).

Este é o texto do termo de permuta, segundo INSTITUTO BIOLÓGICO: "Fica a Secretaria da Fazenda e do Tesouro autorizada a fazer a permuta de quinhentos e cinqüenta mil metros quadrados de terreno pertencente ao patrimônio do Estado contidos na área da Invernada do Corpo de Bombeiros (Invernada dos Bombeiros), no distrito de Vila Mariana, no Município e Comarca da Capital, com $124.000 \mathrm{~m} 2$, pertencentes à Municipalidade da Capital, contidos na área dos que constituem a Escola de Pomologia, à Av. Água Branca, distrito da Lapa, também no Município e Comarca da Capital. Palácio do Estado de São Paulo, em 20 de janeiro de 1928, Julio Prestes de Albuquerque".

Em função da permuta, foi transferido o viveiro de plantas que estava situado no terreno da Água Branca para a área do Ibirapuera (ANDRADE). Aplicaram-se fertilizantes no solo e plantaram-se, na área do futuro parque, mais de 150 mil mudas de carvalhos, pinheiros, ipês, palmeiras, figueiras, tipuanas, plátanos, entre outras espécies (BARTALINI, 1999, p.62). 
Do restante da Invernada dos Bombeiros, que permaneceu sob domínio estadual, ainda em 1928, foi destinada uma área de $332.000 \mathrm{~m} 2$, para implantação do Instituto Biológico de Defesa Agrícola e Animal, hoje apenas Instituto Biológico (SÃO PAULO, 1933, p.827-828).

Alguns enclaves continuariam em litígio judicial: a prefeitura faria tentativas de reaver ou desapropriar essas áreas nas décadas de 1930 e 1940, com sucesso apenas parcial. Tanto que os enclaves da avenida IV Centenário e do início da avenida República do Libano permanecem até hoje (CAMPOS, 2002, p.314).

4.7.4.2. Implantação do Viveiro Manequinho Lopes

Em 1927 foi iniciado por Manuel Lopes de Oliveira Filho, conhecido por Manequinho Lopes, o plantio de eucaliptos para iniciar a drenagem da área pantanosa. Como explica OLIVEIRA (2003, p.73), havia inúmeras depressões lamacentas além de dois córregos cruzando os terrenos, como também um lago próximo ao prolongamento da avenida Brasil. A situação planialtimétrica do local tornava-o muito alagadiço e, portanto, na visão sanitarista da época, de difícil ocupação para fins não rurais. Na medida em que estava determinada a incorporação da área ao tecido urbano em expansão, cabiam intervenções para que ela não fosse considerada inóspita ou "perigosa" à proximidade e utilização citadina.

Manequinho Lopes, também segundo OLłVEIRA (2003, p.77-78), não teria utilizado apenas o plantio de eucaliptos para a drenagem da área, mas também outros sistemas como canais,valas ou mesmo recorrido a aterros. O s eucaliptos também teriam sido usados como sombra para que outras espécies pudessem desenvolver-se.

Embora não tenham sido localizados dados escritos a respeito, como informa OLIVEIRA (2003, p.78), pode-se dizer, com fundamento no que lá existe, 
que a plantação dos eucaliptos demonstra a existência de linhas diretoras, desenhos que permitissem o aproveitamento mais racional das mudas e a melhor ocupação da área. Assim, há um número maciço de árvores, próximas e relacionadas por linhas geométricas claras, de modo a resolver um problema da melhor forma possível para o momento, além de contribuir com a marcação para a construção da paisagem.

Já em 1928, após o início do plantio dos eucaliptos, Manequinho Lopes instala o viveiro de mudas no Ibirapuera, onde segundo ETZEL (1982, p.70), foram plantadas cem mil mudas de essências para o embelezamento, não apenas do parque, mas de toda a cidade. Com muita água e localização central, a implantação desse viveiro, deu lugar a grandes sementeiras e formação de inúmeras árvores, arbustos, azaléias, além de vasos de flores para canteiros e estufa, pois para lá se removeu a antiga estufa quente do mini-viveiro do Parque da Luz.

Segundo OLIVEIRA (2003, p.79), o viveiro de mudas foi instalado no sudeste da área do futuro parque. Os canteiros, os ripados, estufa e administração foram estruturados em áreas inseridas numa malha quadriculada, praticamente cartesiana, em que se afiguraram três momentos diversos. Logo à entrada, pela avenida Indianópolis (hoje República do Líbano), foram propostos canteiros retangulares baixos, que indicam a chegada a esse espaço, laborando como local de transição entre o entorno e o núcleo central do viveiro. Após esses canteiros, ao redor de um grande ripado, com características de pátio central, foi disposto o conjunto principal das edificações: seis estufas e um edificio administrativo. No prosseguimento, em direção à área destinada à implantação do parque, em seguimento ao conjunto principal, construíram-se ainda outros canteiros e numerosas espécies foram plantadas. Portanto, segundo o mesmo autor, ficou evidente que Manequinho Lopes propôs espaços de transição entre o espaço principal do viveiro, com suas estufas e ripados e as áreas limítrofes, o futuro parque e a então avenida Indianópolis.

Manequinho Lopes construiu edificações simples, de alvenaria, com utilização de alguns elementos metálicos, principalmente nos desenhos das esquadrias. Com aberturas em geral comedidas e de quando em quando utilizando 
telhas translúcidas, essas estufas eram pensadas cada qual para tipos específicos de plantas, de modo que todas elas adquiriram um aspecto bastante semelhante, embora não fossem completamente idênticas. Os desenhos nas esquadrias, utilizando-se de ferro, remetem aos afrescos art nouveau, cada uma delas caracterizada com soluções diferentes. Não há registros sobre a existência de algum arquiteto responsável. Sabese apenas que o conjunto de intervenções no espaço destinado ao viveiro de mudas ficou sob a responsabilidade direta e constante fiscalização de Oliveira Filho (OLIVEIRA, 2003, p.82).

Em 1934, Manuel Lopes foi indicado chefe de divisão de matas, parques e jardins. Com seu conhecimento, prestou inúmeros serviços e distribuiu beleza pela cidade. Após seu falecimento, em fevereiro de 1938, o viveiro foi batizado de “Manequinho Lopes”, por Decreto de 14/03/1938 (SÃO PAULOe).

Durante as décadas de 1940 a 1960. o trabalho de ajardinamento, arborização urbana e manutenção de áreas verdes ficou a cargo dessa divisão, sendo o viveiro Manequinho Lopes o responsável pelo fornecimento de plantas ornamentais, frutíferas e herbáceas, além de contar com complexa estrutura de carpintaria, serraria, oficinas, etc. (SÃO PAULOe).

Ainda em 1929, mal iniciada a implantação do parque, já surgia a primeira tentativa de descaracterização e privatização da área. A Lei 3.256 de 21/01/1929 previa a transferência do Jóquei Clube, que se situava na Mooca para os terrenos do Ibirapuera (ANDRADE).

\subsubsection{Primeiros projetos paisagísticos}

Para o parque foi encomendado um projeto paisagístico e de plantio de espécies ao arquiteto paisagista Reinaldo Dierberger, que havia sido o autor da reforma do Parque da Independência, ocorrida em 1922, que resultou no seu traçado 
atual (MACEDO e SAKATA, 2002, p.175). Finalizado em 1930, seu desenho para o Ibirapuera baseava-se na provisão de grandes espaços de lazer, uma vez que, segundo o próprio autor, "a periferia da capital distendeu-se [...] numa vertigem de progresso insaciável [...] São Paulo [...] caminha na retaguarda com seus parques e logradouros públicos, não tendo nada comparável ao 'Palermo' de Buenos Aires ou aos jardins do Rio. Propunha então "um grande e verdadeiro parque público" no Ibirapuera, que proporcionasse contato com a natureza, campos esportivos, piscinas e lagos para atividades náuticas. Aléias, avenidas, bosques e gramados combinariam perspectivas clássicas, incluindo renques de árvores e composições simétricas, com "trechos pitorescos". Uma seqüência central de parterres, alamedas e sebes ligaria os portões de entrada, junto da avenida Brasil, ao extremo oposto. Em torno desse "jardim arquitetônico" estariam distribuídos um teatro ao ar livre, campos de futebol e tênis, arena hípica, pista de atletismo; clube e cassino municipal, articulados por eixos de simetria e entremeados por bosques (Dierberguer apud CAMPOS, 2002, p.315-316).

De modo geral, a estruturação do parque é perceptível essencialmente por quatro aspectos: a presença de amplos espaços gramados e arborizados, a definição de vias para passeio de pedestres, a implantação de formas geométricas marcantes e o grande eixo central no prolongamento da avenida Brasil (OLIVEIRA, 2003, p.115).

Nas palavras de CAMPOS (2002, p.316), o paisagismo classicizante de Dieberger reporta-se ao trabalho do urbanista e paisagista francês Jean-Claunde Forestier, particularmente seus projetos de 1921-1924 para a faixa das antigas fortificações de Paris, e seu plano para Buenos Aires, cujos parques foram desenhados com os mesmos ciprestes que pontuavam o projeto do Ibirapuera. Tal jogo entre elementos axiais e simétricos e trechos informais também caracterizava os campi universitários norte-americanos e os arranjos de exposições internacionais. Era considerada linguagem adequada à representação da natureza, em formas que dessem vazão às necessidades eminentemente urbanas de lazer ativo e disciplinamento institucional do tempo livre. 
Exceto no eixo central, os espaços ajardinados do parque encontram-se desvinculados de uma geometrização mais intensa. Tais espaços, ao não possuírem uma definição precisa de programa ou sugestão de formas de utilização, apresentamse como locais propícios a diferentes apropriações, como também se tornam passíveis de usufruto para grupos das mais variadas idades. Evidencia, nas palavras do próprio Dierberger, “um parque popular" (OLIVEIRA, 2003, p.115-116).

Entretanto, como explica OLIVEIRA (2003, p.119), os programas de utilização do parque sugerem que a idéia de "parque popular" parece pautada nas atividades de elite, já que vemos sugeridos espaços para cassino, turfe e golfe, práticas não habituais nem mesmo às elites, quanto mais às demais classes da sociedade.

É de se observar, inclusive, que no espaço central do parque, portanto, em local privilegiado, encontram-se dois símbolos que marcam uma posição clara de demonstração dos interesses e do ideário das elites econômicas paulistanas: o cassino e o roseiral, referências ao poder econômico e à cultura e civilidade (OLIVEIRA, 2003, p.120).

Por sua vez, é prevista a sua conexão com o sistema viário dos bairros aristocráticos vizinhos. Dierberger projetou uma série de entradas por todo o perimetro da área. A mais importante delas é uma avenida central, que se inicia na avenida Brasil, prolonga-se até a rua França Pinto (hoje avenida IV Centenário), com grandes gramados a seus lados e conduz a um estádio de ginástica e jogos olímpicos. Uma segunda entrada de destaque encontra-se na junção da então Auto-Estrada (atual avenida República do Líbano) e a rua França Pinto (avenida IV Centenário). Nesta existe outra via com plantações arbóreas margeando seu percurso, cujo foco é um estádio (OLIVEIRA, 2003, p.124). O projeto também prevê uma comunicação entre a rua Abilio Soares e a estrada Washington Luiz (hoje avenida Ruben Berta), uma avenida larga e paralela à rua Manoel da Nóbrega, que cortaria o parque em duas partes transversais (OLIVEIRA, 2003, p.I17). 
Não existe no projeto nenhuma referência direta ao viveiro de mudas implantado por Manequinho Lopes. Mesmo assim, o plano demonstra preocupação com a divulgação científica, com o entendimento do parque como área de cultivo e propagação do conhecimento botânico, para além das suas características de, embelezamento, saneamento, espaço de recreação, lazer e cultura. Tanto que destina uma área nas proximidades de uma "torre-mirante" para a divulgação de espécies nativas e um local, nas imediações do estádio, para a cultura de plantas e estufas (OLIVEIRA, 2003, p.125).

Em hábil síntese informa OLIVEIRA (2003) que o projeto de Dierberger, entendido como ação urbanística, assume responsabilidades de saneamento e embelezamento da área. Não bastaria, em seu projeto, apenas um parque que fornecesse áreas verdes de recreação em geral. Era fundamental que participasse do contexto de embelezamento da cidade, que se articulasse com o entorno, o centro e novas obras; que proporcionasse espaços higienizados e de uso ao ar livre para as elites dos bairros privilegiados, bem como respondesse a critérios estéticos e de propagação do conhecimento. Em sua concepção seria ao mesmo tempo belo, útil, higiênico e propagador do bom gosto e da botânica.

Porém, não se deve olvidar que, segundo CAMPOS (2002, p. 316-317), mantida a proposta de Reinaldo Dierberger, o Parque do Ibirapuera surgiria como espaço de lazer privilegiado, anexo aos bairros-jardins, desmentindo a vocação de parque popular e metropolitano reivindicada pela prefeitura. A transformação do Ibirapuera em um jardim de luxo, cuja monumentalidade ecoaria os valores da capital agroexportadora, acabaria não ocorrendo, pois em virtude da crise da economia cafeeira após 1929 , o projeto não foi implantado.

Em 1932, na gestão do prefeito Goffredo da Silva Telles, em plena revolução constitucionalista, o Ato 378 de 29 de julho aprova um novo projeto para o parque, também de Dierberger, que incorpora o prolongamento previsto para a avenida Brasil, mas desconsidera o loteamento de 1918 (Jardim Lusitânia), utilizando esta área para o parque. O projeto concentra-se na disposição de atividades de esporte, diversão e cultura dentro do conjunto de logradouros, bosque, passeios, 
ruas, caminhos, lagos e avenidas, deixando bem clara a instalação de um hipódromo (ANDRADE). Este especial interesse na instalação do hipódromo dentro do parque decorre naturalmente do fato de que a referida Lei 3.256/1929, que aprovou tal implantação, foi de iniciativa do prefeito Telles enquanto vereador (CAMPOS, 2002, p.348). Mas este projeto foi recusado pela Repartição de Águas e Esgotos de São Paulo em 1933, por desconsiderar problemas como água e esgoto (ANDRADE). Ele foi revisado e aprovado pelo Ato 459 de 11/05/1933, intitulado como "Revisão do Projeto do Parque do Ibirapuera". Apesar de ser o primeiro projeto legalmente aprovado, tanto na versão inicial como na revisada, não teve seguimento (ANDRADE). Outro projeto, da autoria do engenheiro Werner Hacker, datado de 1935, teria o mesmo destino (ANDRADE).

Os projetos aprovados até então nunca foram completamente finalizados. Comprova-se por processos internos municipais e por fotos aéreas da época que apenas parte do sistema viário principal proposto foi executado. As edificações, os passeios e os jardins não passaram de intenção de projeto (ANDRADE).

Mesmo assim, na gestão municipal de Fábio Prado (1934-1938) seriam abertos caminhos, criado o lago e feitos estudos para a plantação de espécies nativas, como também pairaria uma nova ameaça sobre o parque: a construção de um aeroporto, felizmente mal sucedida (PRADO, 1936, p.97-98). Na mesma gestão, em 1936, foi definido o local do Monumento às Bandeiras, de Victor Brecheret, que por quase duas décadas foi executado in loco pelo escultor e que mais tarde seria envolvido pelas duas pistas da avenida Brasil, tornando-se importante ponto referencial para o parque (KLIASS, 1993, p.165).

Somente em 1948, segundo ANDRADE, surgiria nova proposta para o Ibirapuera, realizada por membros internos da prefeitura, datada de 14 de janeiro desse ano. Ainda conforme ANDRADE, o desenho existente apenas lista uma série de edifícios a serem construídos, suas áreas e valores de construção. Não se pode definir o estilo arquitetônico desses edifícios, porém é possível afirmar que são de grande vulto pela leitura da implantação. O projeto reafirmava a existência de uma praça circular, prevendo a implantação no seu centro do Monumento ao Soldado 
Constitucionalista, cuja localização no parque somente seria oficialmente definida no ano seguinte.

Assim sendo, em 1949 seria definida a localização do Monumento ao Soldado Constitucionalista (obelisco) (MACEDO e SAKATA, 2002, p.183). Projeto do escultor Galileo Emendabili e do arquiteto Mario Pucci, o término de suas obras estava previsto para 1952; porém estenderam-se por mais algum tempo em razão da falta de verbas, sendo dadas por terminadas apenas em 1978, embora ficassem faltando alguns pormenores, como duas piras votivas, que faziam parte do projeto original (REIS FILHO, 1982, p.42).

\subsubsection{Exposição do IV Centenário}

Quando da comemoração do quarto centenário da Cidade de São Paulo, o poder público considerou a área do Ibirapuera ideal para as festividades, pelos seguintes motivos: por se constituir em área reservada para parque, sem projeto definitivo implantado; pela proximidade do centro e facilidade de acesso; pela proximidade com a população mais envolvida nas comemorações: famílias tradicionais paulistanas, população voltada à cultura, às artes e à tecnologia (MARIANO, 1992, p.97). Apesar dessas vantagens, persistiam problemas de invasão da área reservada para parque, como se pode ver pela favela que lá existia, conforme fotos de 1951 em BONDUKI (1998, p.271). Para a construção do parque, de acordo com LOFEGO (2004, p.83-84), seriam removidos 186 barracos, que abrigavam 204 famílias, da área situada entre as ruas Abílio Soares e Manoel da Nóbrega.

A área reservada para parque nessa época, segundo KLIASS (1993, p.165), era delimitada pelas ruas Manuel da Nóbrega, Abílio Soares, Curitiba, pelo córrego Caguaçu, avenidas Brasil, IV Centenário, rua França Pinto e avenida República do Líbano, montando cerca de $1.800 .000 \mathrm{~m} 2$. 
Em 1948, de acordo com ANDRADE, era criada a "Comissão de Festejos Comemorativos do IV Centenário da Fundação da Cidade", responsável por elaborar o plano geral das comemorações, dar parecer sobre todos os planos, projetos e propostas referentes às comemorações e propor providências administrativas e legislativas. Entre os anos de 1949 e 1951, ela sofreria várias reorganizações.

O arquiteto Christiano Stockler das Neves apresentou em 1951 à comissão um parecer sobre o projeto de 1948 e, em seguida, sua proposta para o Parque do Ibirapuera, que incorporaria os modelos de jardim inglês, francês e italiano. O seu projeto ainda ressaltaria a monumentalidade dos edifícios e dos grandes boulevares a serem incorporados ao parque, deixando claro que o viveiro Manequinho Lopes deveria ser removido para outro local (ANDRADE). Este projeto não seria aceito pela comissão.

A Comissão do IV Centenário da Cidade de São Paulo, em sua versão definitiva, foi criada pela Lei Municipal 4166 de 29/12/1951, como autarquia, a ser composta por sete membros nomeados pelo prefeito, dos quais três obrigatoriamente indicados pelo governador do Estado. Para esta comissão foram nomeados Francisco Matarazzo Sobrinho, como presidente, Joaquim Canuto Mendes de Almeida, Carlos Alberto Alves de Carvalho Pinto, João Pacheco Fernandes, José de Melo Morais, Mario Beni e Oscar Pedroso Horta (TORRES, 1977, p.101-102).

Esta comissão designou uma equipe de arquitetos; liderada por Oscar Niemeyer para elaborar o projeto arquitetônico e paisagístico para a área. Além de Niemeyer, integravam o grupo Eduardo Kneese de Mello, Ícaro de Castro Mello, Hélio Ulhoa Cavalcanti, Zenon Lotufo e Octávio Augusto Teixeira Mendes (KLIASS, 1993, p.165). Responderam pelo projeto arquitetônico Oscar Niemeyer, Hélio Ulhoa Cavalcanti, Zenon Lotufo, Eduardo Kneese de Mello, com a colaboração de Gauss Estelita e Carlos Lemos (MARIANO, 1992. p.98-99).

Embora freqüentemente atribuído a Roberto Burle Marx, o projeto de paisagismo efetivamente implantado na década de 1950 é de autoria do engenheiro agrônomo e paisagista Octavio Augusto Teixeira Mendes, que por ocasião do projeto 
do parque era diretor geral do Serviço Florestal do Estado (hoje Instituto Florestal) (MARIANO, 1992,p.105). Efetivamente Burle Marx elaborou um projeto nos anos 1950 que não chegou a ser implantado (MACEDO e SAKATA, 2002, p.183).

A proposta paisagística levava em consideração a vegetação existente e que deveria ser preservada a todo o custo. Mesmo assim, houve necessidade de remoção de várias árvores. Muitos eucaliptos tiveram de ser sacrificados. Outros foram transferidos para a formação de novos bosques, tudo dentro do plano paisagístico inicial. Muitas árvores não poderiam ser aproveitadas, pois os terrenos estavam ocupados por construções e toda sorte de materiais. Entretanto, numa iniciativa pioneira, elas foram utilizadas na arborização das margens da Via Anchieta. Foram transplantadas numerosas árvores para replantio entre os quilômetros 14 e 40 daquela rodovia (TORRES, 1977, p.106).

O projeto arquitetônico realizado constou de quatro pavilhões de exposição: o Palácio das Nações, com uma área de 150 x 42 metros; o Palácio dos Estados, de mesmas dimensões; o Palácio das Exposições, de base circular, com 76 metros de diâmetro e cobertura em forma de cúpula e o Palácio das Indústrias, o maior deles, com área de $250 \times 50$ metros. Todos interligados por uma grande marquise de forma irregular, com 620 metros de comprimento e largura variando entre 15 e 80 metros, com área total de 28.800 metros quadrados (TORRES, 1977, p.147-148).

Foram construídos ainda dois pavilhões provisórios de estrutura metálica: o Pavilhão Verde, complemento do Palácio das Indústrias, com 5.610 metros quadrados e o Pavilhão da I Feira Internacional de São Paulo, com 20.000 metros quadrados (TORRES, 1977, p.148).

O Pavilhão da Agricultura foi projetado pela equipe de Niemeyer em separado, na área pertencente ao lnstituto Biológico. Este cederia parte de sua gleba para a construção do palácio, a ser realizada pela Comissão do IV Centenário, com sua própria verba. Ao término das comemorações, ele seria incorporado ao 
patrimônio da Secretaria de Estado da Agricultura, o que não ocorreu (TORRES, 1977, p.106-107).

Fora do projeto foi inaugurado o Pavilhão Japonês, doado pela colônia japonesa de São Paulo, que é uma réplica do Palácio Katura de Quioto, com suas características típicas da arquitetura japonesa de madeira (SÃO PAULOb).

Embora previsto no projeto original, o planetário, primeiro da América Latina, seria inaugurado apenas em 26/01/1957. Ocupa um edificio de forma circular com uma cúpula metálica de 20,06 metros de diâmetro e 13 metros de altura (TORRES, 1977, p. 121). Tombado em nível estadual e municipal, foi projetado por Eduardo Corona, Roberto G. Tibau e Antonio Carlos Pitombo (SÃo PAULOf). A seu lado existe atualmente a Escola Municipal de Astrofisica desde 1961 (SÃO PAULOb).

Foram implantados três lagos artificiais interligados, numa área total de 157.000 metros quadrados. Cortando vários pontos desses lagos foram construidas sete pontes de concreto armado (TORRES, 1977, p.149).

O ginásio esportivo, de forma circular, com 94,40 metros de base, com cobertura de concreto armado com 107 metros de diâmetro, projeto do arquiteto Ícaro de Castro Mello, com capacidade original para 20 mil espectadores (hoje 11 mil), somente seria inaugurado em 25/01/1957. O velódromo, por sua vez, inaugurado em 06/11/ 1954, acabou por tornar-se um estádio de atletismo para 13 mil espectadores, em 1974 (TORRES, 1977, p.149 e SÃO PAULO).

Não foram construidos um auditório, a plataforma de entrada e um restaurante à beira do lago (OLIVEIRA, 2003, p.275)

A estética de seu conjunto traduz os parâmetros do modernismo, que podem ser identificados no traçado menos formal de seus caminhos, na articulação de seus ambientes e equipamentos, na diversidade das atividades, no uso da vegetação nativa e tropical, e no desenho de scus edificios (MACEDO e SAKATA, 2002 , p.183). Entretanto, seu uso voltado essencialmente para uma grande exposição, 
implicou na implantação de um excesso de áreas impermeabilizadas para um parque público, formado por vias de tráfego de veículos e estacionamentos asfaltados.

Como expressa KLIASS (1993, p.165), ao mesmo tempo em que o projeto da equipe de Niemeyer deu vida à área, transformando-a em local de uso e recreação para a população, também criou um conflito de funções que continua até hoje. A concepção do parque, mais arquitetônica que paisagística dotou a área de um conjunto de edificações, interligadas por uma marquise, que deveriam permanecer definitivamente abrigando funções culturais.

Naquela época não havia atividades culturais suficientes na cidade para preencher todas aquelas edificações que se tornaram disponíveis no Parque do Ibirapuera. E a prefeitura municipal historicamente sempre dispôs de poucos imóveis de seu domínio para instalação de órgãos administrativos. Não demoraria muito tempo para que o Ibirapuera, programado como local de lazer e cultura para a população, fosse descaracterizado e transformado num verdadeiro centro administrativo improvisado.

\subsubsection{Decadência e descaracterização}

O primeiro degradador foi o governo estadual, em detrimento do Instituto Biológico e da Secretaria da Agricultura. Menos de um ano após a inauguração, o Palácio da Agricultura foi transformado em sede do Departamento Estadual de Trânsito - DETRAN (TORRES, 1977, p.115). A presença do DETRAN determinou a descaracterização de grande área ao seu redor, transformada em pátio de emplacamento, estacionamentos, lanchonetes e pequenas edificações utilizadas por despachantes e outros serviços pertinentes ao grande afluxo de pessoas gerado pela presença de uma repartição de trânsito, sem contar os congestionamentos de veículos ocasionados nas ruas próximas. 
O Palácio das Nações, depois denominado Pavilhão Manoel da Nóbrega, passou a sediar em 1961 o gabinete do prefeito, além de vários outros órgãos públicos. O Palácio dos Estados, depois Pavilhão Armando de Arruda Pereira, passou a abrigar a PRODAM, empresa de processamento de dados do Município.

O Palácio das Exposições (Pavilhão Lucas Nogueira Garcez) e o Palácio das Indústrias (Pavilhão Francisco Matarazzo Sobrinho) mantiveram atividades culturais, se bem que bastante improvisadas: o primeiro servindo de sede por longos anos para os Museus do Folclore e da Aeronáutica e o segundo para as Bienais e para o Museu de Arte Contemporânea.

Embora o espaço sob a marquise tivesse sido planejado para ser mantido como passagem livre, sem nenhuma interferência, tal premissa não se manteve. Tanto que em 1959 foi construído sob a marquise o chamado "Pavilhão Bahia", caixote de concreto que abrigou nesse ano exposição sobre o estado baiano e que reformado, em 1968, tornou-se sede do Museu de Arte Moderna de São Paulo. Seria novamente reformado em 1982, com projeto de Lina Bo Bardi, cuja implantação foi completada apenas em 1996 com a construção de auditório e espaço para restaurante (MAM). O Museu de Arte Moderna permanece no mesmo local até hoje.

Em 1969, seria a vez do Museu dos Presépios instalar-se sob a marquise, no chamado "Pavilhão do Folclore", já existente em 1957, e que na verdade não passava de um depósito improvisado. Sua principal atração era um presépio napolitano barroco, trazido em 1949 da Itália por Francisco Matarazzo Sobrinho (Ciccillo Matarazzo) e doado à municipalidade. Este museu permaneceu neste local, sofrendo com o excesso de umidade, até a transferência de seu acervo em 1985 para o Museu de Arte Sacra (WALKER, 2002, p.64-66).

O viveiro Manequnho Lopes foi transformado em sede do Departamento de Parques e Jardins e ainda, desde março de 1974, foi ali instalada a Secretaria de Serviços Municipais. Nas suas proximidades, por certo período, eram depositadas carteiras, balanços e outros materiais de grupos escolares e parques infantis (TORRES, 1977, p.115-116 e 120-121). 
Um prédio construído na década de 1940 , com cerca de 1.500 metros quadrados de área, situado na avenida IV Centenário serviria de sede para o Departamento Municipal de Edificações (BARROS, 2008, p.C4).

Áreas internas do parque foram cedidas sem critério a particulares, que passaram a se portar como se delas fossem proprietários. Assim aconteceu com o Kennel Clube, a Sociedade Paulista de Cães Pastores (TORRES, 1977, p.121), com um cemitério para animais (KLIASS, 1993, p.166) e com as áreas de aeromodelismo, nautimodelismo e ferromodelismo, situadas por detrás do Círculo Militar de São Paulo. Ainda segundo TORRES (1977, p.120), até mesmo um funcionário municipal residia confortavelmente instalado no parque, com uma criação de porcos nas imediações dạ avenida IV Centenário.

Inclusive uma boate, o Café Concerto, existiu dentro do Parque do Ibirapuera. Ela ocupava um pavilhão construído em 1954 destinado originalmente à exploração pelo Instituto Brasileiro do Café - IBC, com a finalidade de divulgar o café brasileiro. Após algum tempo de funcionamento, o pavilhão ficou abandonado por diversos anos, quando foi reformado pelo próprio IBC. Na gestão do prefeito Figueiredo Ferraz (1971-1973), o IBC conseguiu uma autorização para voltar a utilizar o local para divulgação do café. Porém, em desacordo com o autorizado, o IBC licitou o local em 1972, que passou a ser utilizado como casa de shows (O ESTADO DE S. PAULO, 1975).

No início da década de 1970 também funcionou no Ibirapuera um parque de diversões privado chamado "centro de diversões" com montanha-russa e toboágua, que se transferiu em 1973 para a avenida Marginal Tietê, onde originou o atual Playcenter (VIAGEM NO TEMPO)

Por sua vez, a ausência de cerca transformava o excessivo número de vias asfaltadas existente no interior do parque em verdadeiras avenidas, utilizadas pelos motoristas para cortar caminho e desviar de congestionamentos.

Em 1974, o próprio Oscar Niemeyer afirmava que: "o Ibirapuera se resume hoje numa série de lotes cortados por circulação de veículos; os prédios estão 
adulterados; a marquise completamente ocupada; a finalidade da área acabou se desvirtuando, o que é lamentável. O Ibirapuera é atualmente um recanto da cidade com circulação de veículos por todos os, lados, quando a idéia era justamente o contrário,ou seja, a implantação de um grande jardim", apud TORRES (1977, p.126). Não deixa de ser paradoxal a opinião do ilustre arquiteto, na medida em que a existência de uma excessiva malha viária dentro do parque, elaborada conforme o projeto de sua equipe, numa cidade de trânsito intenso, só poderia resultar mesmo em incentivo ao tráfego. Sem contar a sua pública manifestação contrária ao cercamento do parque (TORRES, 1977, p.127), que como ficaria demonstrado posteriormente, tornou-se fator decisivo para impedir a circulação de veículos dentro do Ibirapuera.

Especialmente a parte original do parque em torno do ginásio esportivo e velódromo (hoje Conjunto Desportivo Constâncio Vaz Guimarães) veio a sofrer através do tempo várias retaliações e cessões, de modo a simplesmente desaparecer como área verde.

$\mathrm{O}$ perímetro desta área do parque, remanescente da invernada dos bombeiros, é formado pela avenida Pedro Álvares Cabral, rua Manoel da Nóbrega, rua Tutóia, rua Abílio Soares, rua Curitiba e avenida 23 de Maio.

Na década de 1960, todo o espaço que separa o conjunto desportivo do parque do Ibirapuera (avenida Pedro Álvares Cabral), entre as ruas Manoel da Nóbrega e Abílio Soares, foi desmantelado, pela construção em 1968 do prédio da Assembléia Legislativa. Para tanto, inclusive, foi feita a secagem de um dos lagos do parque (MARIANO, 1992, p.112). Foi ainda edificado a a lado o quartel-general do Comando Militar Sudeste, cercado por duas avenidas largas. Como resultado, o conjunto desportivo ficou totalmente isolado do Parque do Ibirapuera por uma ampla área impermeabilizada.

Mesmo o programa do conjunto desportivo, sob gestão estadual, foi se distanciando cada vez mais do parque. Além do ginásio esportivo e do velódromo (hoje estádio de atletismo), foi inaugurado um conjunto aquático em 1968, com cinco piscinas, um tanque de saltos e arquibancada para 5.600 pessoas e um ginásio 
poliesportivo para 3.000 pessoas em 1982 (SÃO PAULO). Tudo impermeabilizado e sem qualquer tratamento paisagístico, de modo a romper qualquer vínculo subsistente, ainda que tênue, com o Parque do Ibirapuera original.

Além disso, vizinho do referido conjunto desportivo, existe outra grande área do parque ocupada pelo Exército, com frente para as ruas Manoel da Nóbrega, Tutóia e Abilio Soares, onde havia um quartel, hoje demolido, que teve sua cobertura arbórea arrasada. Atualmente contém apenas algumas instalações, entre as quais edifícios de habitação militar. O Exército, segundo AUGUSTO (2007), tomou conta de um total de $120.000 \mathrm{~m} 2$ do parque. Dentro desse vasto terreno encontramos cerca de oito pequenas ruas sem saída, com entradas pelas ruas Tutóia e Manoel da Nóbrega, muito possivelmente resultantes de invasões ou cessões irregulares de áreas do Parque do Ibirapuera.

Já o Círculo Militar de São Paulo é uma entidade privada que 'ocupa $31.005,20 \mathrm{~m} 2$, por concessão de uso gratuita do Município, a última das quais datada de 14/01/1987, pelo prazo de 25 anos (FOLHA ON LINE, 2002), sem prestar qualquer serviço que seja à comunidade. E como se não bastasse, o local ocupado pelo Círculo Militar é também uma praça denominada Eisenhower, portanto indiscutivelmente bem de uso comum do povo. Nessa mesma praça ainda foi construída uma escola municipal.

4.7.4.6. Melhorias a partir da década de 1970: situação atual

Na gestão Figueiredo Ferraz (1971-1973) foi decidida a instalação de gradis para cercar o parque. Não obstante a oposição dos arquitetos Oscar Niemeyer, Zenon Lotufo e do paisagista Teixeira Mendes, que alegavam que a cerca descaracterizaria o projeto do parque, prevaleceu a necessidade de se garantir a 
segurança dos usuários (TORRES, 1977, p.123 e 127). A partir daí houve sensível melhora na freqüência do parque.

Na gestão Olavo Setúbal (1975-1979) houve uma série importante de melhoramentos no Parque do Ibirapuera, no sentido de recuperar a sua finalidade de área verde a ser fruída pela população. O Café Concerto foi fechado e o pavilhão do IBC, por ele ocupado, retomado (O ESTADO DE S. PAULO, 1975). Os pavilhões do IBC, Verde e da I Feira Internacional, este último abandonado desde 1971 (TORRES, 1977,p.125) foram demolidos e suas áreas transformadas em jardins. O viveiro Manequinho Lopes foi aberto ao público, sendo demolidos os edifícios administrativos que atravancavam o lugar, bem como o muro que o separava do Ibirapuera. Foram $100.000 \mathrm{~m} 2$ que se incorporaram efetivamente ao parque (O ESTADO DE S. PAULO, 1979). O cemitério de animais, próximo da avenida IV Centenário, foi extinto.

A partir da década de 1990 os pavilhões do Parque do Ibirapuera, quase todos transformados em repartições públicas, começaram a ter o seu panorama modificado. Em 1991 o gabinete do prefeito retirou-se do Pavilhão Manoel da Nóbrega que foi cedido para a administração estadual em 1992. A partir dessa época foi cogitado para abrigar parte da Pinacoteca do Estado, o que acabou não ocorrendo. Em 2004 o pavilhão retornou à administração municipal e em 23 de outubro do mesmo ano foi nele inaugurado o Museu Afro-Brasil (MUSEU AFRO BRASIL).

A PRODAM retirou-se do Pavilhão Armando de Arruda Pereira, que foi então oferecido ao Museu de Arte Moderna, que não aceitou, em virtude da necessidade de reformas. A partir de então o prédio tem sediado exposições temporárias. A prefeitura tem planos de reformar o prédio ainda em 2008 para nele instalar um museu formado a partir de dois acervos. Um deles é o do Museu do Folclore Rossini Tavares de Lima, que estava instalado na Oca até 1999 e hoje está precariamente instalado na Casa do Sertanista, no Caxingui, o que motivou uma interpelação do Ministério Público. O outro é a coleção da missão de pesquisas folclóricas coordenada por Mário de Andrade em 1938, que está atualmente sob a guarda do Centro Cultural São Paulo (CYPRIANO, 2008, p.E3). 
O Pavilhão Lucas Nogueira Garcez, mais conhecido por Oca, deixou dt sediar o Museu do Folclore e o Museu da Aeronáutica em 1999, passando a abriga] exposições temporárias, organizadas pelo então banqueiro Edemar Cid Ferreira Com a quebra deste empresário, seu destino permanece incerto. Os acervos dos Museus do Folclore e da Aeronáutica estão se deteriorando, o primeiro na Casa dc Sertanista e o segundo no Centro Municipal de Campismo - CEMUCAM. O que $\dot{\epsilon}$ deveras lamentável.

Sob a justificativa de que o projeto original da equipe de Niemeyer previa a implantação de um auditório, foi iniciada a sua construção em fevereiro de 2004 . O auditório do Ibirapuera, inaugurado em 14/12/2004, foi custeado por uma empresa de telefonia celular, que criou uma OSCIP para administrá-lo em conjunto com a municipalidade (PREFEITURA DA CIDADE DE SÃO PAULO, 2004). Esta construção, projeto de Oscar Niemeyer, implicou na remoção de numerosas árvores e na impermeabilização de mais $4.870 \mathrm{~m} 2$ do parque (metragem do piso térreo). Sem contar que se São Paulo era uma cidade carente de espaços teatrais em 1954, hoje se encontra bem abastecida deles, não se justificando a construção de mais um, de tamanho insuficiente (apenas 800 lugares) e ainda por cima dentro de um parque municipal já assoberbado de concreto e asfalto, bastante procurado por um público carente de áreas verdes. Aliás, nem mesmo o projeto construído foi o original, conforme se vê em OLIVEIRA (2003, p.278). E imaginar que tudo isto ocorreu apesar do Parque do lbirapuera ser bem tombado pelo Município desde 1991 e pelo Estado desde 2001 (SÃO PAULOb).

Como ressalta LEFÈVRE (2005, p.166-167), tendo em vista o tombamento municipal do parque, o CONPRESP (Conselho Municipal de Preservação do Patrimônio Histórico, Ambiental e Cultural da Cidade de São Paulo) aprovou a realização do projeto em 31 de março de 2003, desde que fosse respeitada integralmente a configuração da marquise atual, que não poderia sofrer nenhuma mutilação. Porém, no projeto de 2003, a posição do auditório foi avançada em direção à entrada para que seu eixo maior coincidisse com o eixo da cúpula. Assím, para que ocorresse a união entre a cúpula e o auditório por uma nova marquise, a 
ponta da grande marquise existente deveria ser cortada e fechada por uma parede curva. A esplanada seria redesenhada, de maneira que a ponta fechada da marquise ficasse no eixo de aproximação e que o piso cimentado alcançasse e envolvesse a maior parte dos volumes do auditório e da cúpula. Em suma, um novo projeto, bastante diferente daquele de 1953, com alteração da grande marquise, que seria mutilada, em desrespeito à diretriz do CONPRESP. Este felizmente não aprovou tal mutilação final, apesar das reclamações infindáveis de Niemeyer e discípulos.

A partir de 2006, o prédio até então ocupado pelo Departamento Municipal de Edificações da prefeitura passou a sediar a chamada Universidade Livre do Meio Ambiente e da Paz - UMAPAZ, que organiza cursos, oficinas e palestras. Em 08/05/2008, foi instalada no mesmo local uma biblioteca especializada em temas ecológicos e de cultura de paz com um acervo inicial de cerca de 2.500 títulos e 200 teses e trabalhos técnicos, além de discos muiltimídia (BARROS, 2008, p.C4).

Está previsto que o DETRAN finalmente deverá deixar o antigo Pavilhão da Agricultura até o final de júnho de 2008. A partir de então o prédio deve entrar em reformas para vir a sediar o Museu de Arte Contemporânea - MAC no segundo semestre de 2009. Pretende-se nesse prédio unificar o acervo desse museu que se encontra espalhado por dois prédios na Cidade Universitária, além do espaço que dispõe no Pavilhão da Bienal (Francisco Matarazzo Sobrinho). Este acervo contém cerca de dez mil peças, para as quais haverá cerca de 30 mil metros quadrados de área na nova sede. O desenho do projeto do museu sairá do escritório de Oscar Niemeyer (MARTINS, 2008, seção II, p.I e GIOIA, 2008, p.E1).

A partir de 2007 a Secretaria Municipal do Verde e do Meio Ambiente vem fazendo um levantamento que visa integrar o Parque do Ibirapuera a áreas próximas que são mal aproveitadas, especialmente àquelas que ficam do outro lado da avenida 23 de Maio, de modo a ampliar a sua área verde contínua (AUGUSTO, 2007). A partir daí tem-se observado na imprensa notícias no sentido de que o parque estaria reincorporando áreas que teriam sido dele desmembradas, situadas em três quadras. O primeiro quarteirão é aquele cujo perímetro é formado pelas avenidas 
Pedro Álvares Cabral, Dr. Dante Pazzanese, Conselheiro Rodrigues Alves e Ibirapuera contendo as áreas hoje ocupadas pelo DETRAN, pelo Instituto Biológico, pelo Departamento de Águas e Energia Elétrica - DAEE, pela Companhia de Desenvolvimento Habitacional e Urbano do Estado de São Paulo - CDHU e pelo Centro Acadêmico XI de Agosto. O segundo quarteirão, vizinho, é formado pelas avenidas Dr. Dante Pazzanese, Pedro Ȧlvares Cabral, pelas ruas Dr. Astolfo Araújo e Dr. Amâncio de Carvalho, no qual temos as áreas do Instituto de Cardiologia Dante Pazzanese, um estacionamento, o Instituto de Engenharia e uma área remanescente do Instituto Biológico. E o terceiro quarteirão, igualmente vizinho, é o situado entre a avenida Ibirapuera, ruas Tangará e França Pinto, ocupado integralmente pela Companhia Paulista de Obras e Serviços - CPOS (IZIDORO e CREDENCIO, 2008, p.C7 e GIOIA,2008, p.E1).

$\mathrm{Na}$ verdade, está havendo uma interpretação equivocada por parte de alguns periódicos paulistanos. A área que denominamos "primeiro quarteirão" não era integrante original do Parque do Ibirapuera, mas tão somente do Instituto Biológico. Como foi mencionado acima, em 1928 uma parte da Invernada dos Bombeiros foi permutada com o Município pela área que hoje forma o Parque Fernando Costa (CAMPOS, 2002, p.313-314). Como foi também dito acima, outra parte da Invernada dos Bombeiros, ainda em 1928, foi destinada ao atual Instituto Biológico (SÃO PAULO, 1933, p.827-828).

Essa área teve seus limites discriminados pelo Decreto Estadual 6.082 de 14/09/1933 em duas glebas, uma destinada à divisão animal e a outra à divisão vegetal do Instituto Biológico. Suas linhas divisórias respectivas são descritas abaixo, conforme o art. $1^{\circ}$ do referido decreto (SÃO PAULO, 1933, p.827):

\footnotetext{
"Partindo da esquina da Avenida projetada, com a rua Amâncio de Carvalho e a Avenida Conselheiro Rodrigues Alves, segue por esta última onde passa a linha de Tramway de Santo Amaro até o cruzamento dessa avenida com a rua França Pinto, devidamente retificada, até encontrar o terreno da estação de bombas elevatórias da Repartição de Águas e Esgotos, confrontando esse terreno pelo muro existente até de novo atingir a rua França Pinto, devidamente retificada, na esquina formada por essa rua com o prolongamento
} 
projetado na Avenida Brasil; e confrontando com essa Avenida até uma rua e curva que liga essa avenida com a Avenida projetada que é a referida no início desta discriminação, e por esta acima até o ponto de partida, circunscrevendo uma área aproximada de 239.000 (duzentos e trinta e nove mil) metros quadrados que se destina à Divisão Animal do referido Instituto Biológico de Defesa Agricola e Animal".

"Partindo do ponto de cruzamento do córrego do Sapateiro do Matadouro com o alinhamento da rua França Pinto, devidamente retificada, de acordo com o projeto do Parque do Ibirapuera, e por esse córrego abaixo até encontrar uma viela ou rua projetada, e por esta até encontrar uma rua circular, e por esta até encontrar o prolongamento projetado da avenida Brasil e por esta até o ponto de partida, circunscrevendo uma área aproximada de 93.000 (noventa e três mil) metros quadrados, que se destina à Divisão Vegetal do referido Instituto Biológico de Defesa Agrícola e Animal".

No que tange à gleba destinada à Divisão Animal, temos que a "avenida projetada" é atualmente a avenida Dr. Dante Pazzanese; que a linha do "tramway para Santo Amaro" é a antiga linha do bonde para Santo Amaro, hoje trecho da avenida Ibirapuera; que "o prolongamento projetado na avenida Brasil" é a atual avenida Pedro Álvares Cabral; o terreno da "estação de bombas elevatórias da Repartição de Águas e Esgotos" é aquele pertencente ao DAEE. Portanto esta gleba corresponde exatamente ao que denominamos "primeiro quarteirão" acima e que continuou de domínio estadual, não se integrando ao Parque do Ibirapuera. Porém, nada justifica a má gestão que infelizmente sempre assolou aquela área.

Da questão do DETRAN já falamos acima. Em 1955 foram cedidos $22.500 \mathrm{~m}^{2}$, do lado do DETRAN, esquina da avenida Dante Pazzanese, ao Centro Acadêmico XI de Agosto (AUGUSTO, 2007), que instalou um clube para seus associados em parte da área, locando o restante para estacionamento e lanchonete. Junto a essa área, existe uma outra, com entrada pela avenida Dante Pazzanese utilizada como posto de atendimento da Companhia de Desenvolvimento Habitacional e Urbanístico - CDHU. Todas áreas originalmente integrantes do Instituto Biológico e não do Parque do Ibirapuera. Já a instalação do DAEE, como se pode verificar, é preexistente ao Instituto Biológico e ao Parque do Ibirapuera. 
No que diz respeito à gleba destinada à Divisão Animal temos que o "córrego do Sapateiro do Matadouro" está canalizado e segue por baixo do atual parque. Dentro da mesma área do parque estão "a viela ou rua projetada", hoje inexistente e também a "rua circular", projetada para receber o Monumento ao Soldado Constitucionalista, hoje englobada pela área em que se situa esse monumento. Conclui-se que toda esta gleba integra nos dias de hoje o Parque do Ibirapuera, contendo em seu perímetro, aproximadameṇte, o Pavilhão da Bienal, parte da marquise, e a Oca.

Já o que denominamos "segundo quarteirão" também sempre foi de domínio estadual, provavelmente remanescente da Invernada dos Bombeiros. $\mathrm{Na}$ esquina da avenida Dante Pazzanese e rua Dr. Amâncio de Carvalho, oposta ao quarteirão onde fica a sede do Instituto Biológico, existe uma área com bastante cobertura vegetal de porte arbóreo, sob gestão do Instituto Biológico, onde está situada a antiga residência do diretor, hoje sede do museu da instituição. Em 1958 foi cedida pelo Estado de São Paulo a área em que está instalado o Instituto Dante Pazzanese de Cardiologia (INSTITUTO DANTE PAZZANESE), esquina das avenidas Pedro Álvares Cabral e Dr. Dante Pazzanese. Ainda em janeiro de 1988 foi cedida uma área de $12.500 \mathrm{~m} 2$, com entrada pela avenida Dante Pazzanese, ao Instituto de Engenharia, permutada pelo Palácio Mauá, antiga sede desta associação, onde hoje funciona o Fórum Hely Lopes Meirelles (REVISTA ENGENHARIA).

Em 1993 uma área de $12.700 \mathrm{~m} 2$, situada entre o Instituto de Engenharia e o Instituto Pazzanese, foi cedida pelo Estado de São Paulo à União, para abrigar a Justiça do Trabalho. Como o projeto não foi implementado, esta área voltou a ser de posse estadual em março de 2007, sendo imediatamente cedida ao Instituto Dante Pazzanese para abrigar ampliação de suas instalações hospitalares. O Dante Pazzanese, no entanto, decidiu alugar o terreno para um estacionamento, por prazo indefinido, até que a ampliação seja factível. Como se não bastasse, trata-se de um estacionamento sem licença municipal, portanto clandestino (IZIDORO e CREDENCIO, 2008, p.C7). 
O "terceiro quarteirão", por sua vez, serve de longa data como sede do Departamento de Obras Públicas, tradicional repartição estadual e sua sucessora, Companhia Paulista de Obras e Serviços, em edifício antigo, provavelmente contemporâneo da edificação principal do Instituto Biológico. É bem pouco provável que aquela quadra tenha algum dia sido integrante do Parque do Ibirapuera.

Nos dias atuais a poluição do ar e da água dos lagos problemas graves. Especialmente a poluição do ar, considerando o grande número de pessoas que buscam o parque diariamente para se exercitar, cuja saúde corre constante perigo. A região do Ibirapuera tornou-se uma espécie de cruzamento de diversas vias de tráfego que ligam as diversas regiões da cidade. Estas vias, de grande trânsito de. veículos, envolvem inteiramente o parque e até passam por debaixo dele.

Embora seja de pouco conhecimento dos usuários, o Parque do Ibirapuera é uma das regiões da cidade com maior poluição por ozônio da cidade. O ozônio é responsável por uma enormidade de efeitos maléficos à saúde humana, tais como diminuição da resistência do organismo a infecções respiratórias, como gripes, asmas laringites, faringites, pneumonias; danos às mucosas do aparelho respiratório, causando prejuízos à função pulmonar; agravamento das doenças cardíacas; diminuição da capacidade de executar exercícios físicos; irritação nos olhos; envelhecimento precoce (RODRIGUES e BENNATI, 200்1, p.151).

Para sę ter uma idéia das condições de poluição do ar na região do Parque do Ibirapuera, medições efetuadas de concentração de ozônio no ar em 07/06/2000, em onze estações da CETESB, colocaram essa região em terceiro lugar, perdendo apenas para o bairro de Santana e para o centro de Cubatão (apud RODRIGUES e BENNATI, 2001, p.158). Em São Paulo, a região do Ibirapuera, nos anos de 2000, 2001 e 2002, foi a que mais dias ultrapassou o padrão aceitável de concentração de ozônio na atmosfera. Conforme a CETESB, a ultrapassagem do padrão ocorreu por, respectivamente, 42, 50 e 53 dias (apud SVMA e IPT, 2004, p.77).

No que tange aos lagos, ela decorre dos córregos que os abastecem e já existe pelo menos desde a inauguração do parque, agravando-se com o passar dos 
anos, pelo adensamento populacional da região. Pelo que consta, essa poluição das águas decorre de ligações clandestinas de esgoto que persistem, ano após ano, apesar das promessas dos administradores de plantão de que será encontrada finalmente a solução para o problema.

Tendo em vista a carência e má distribuição das áreas verdes da cidade, a facilidade de acesso, as grandes dimensões e mesmo o valor simbólico e afetivo do parque, torna-se outro sério problema o excesso de usuários, especialmente nos finais de semana e na realização de eventos, como shows e exposições. Basta verificar que em dias de semana, o Ibirapuera tem uma freqüência diária média de 20 mil usuários, aos sábados de 70 mil e aos domingos de 130 mil (SÃO PAULOb), o que equivale à população de uma cidade de médio porte. Esta sobrecarga resulta em danos à vegetação, excessiva geração de residuos sólidos, agravamento da poluição do ar em razão do tráfego e congestionamento de veículos.

Atualmente o parque tem $1.585 .000 \mathrm{~m} 2$ de área total, sendo $185.000 \mathrm{~m} 2$ externos (estacionamento do DETRAN, Obelisco, pista de aeromodelismo, recintos de nautimodelismo e ferromodelismo, praças) e $1.400 .000 \mathrm{~m} 2$ de área interna ao gradil. Nesta área temos $1.043 .000 \mathrm{~m} 2$ de áreas verdes e permeáveis, $150.000 \mathrm{~m} 2 \mathrm{de}$ lagos, $192.000 \mathrm{~m} 2$ de áreas impermeabilizadas (quadras, ciclovia, estacionamentos, vias, calçadas, pisos internos), $4.200 \mathrm{~m} 2$ de gradil, $27.300 \mathrm{~m} 2$ de grande marquise e $62.000 \mathrm{~m} 2$ de edificações (projeção) (SÃO PAULOb).

Tendo em vista que a área destinada ao parque tinha $1.500 .000 \mathrm{~m} 2 \mathrm{em}$ 1916 (TORRES, 1977, p.97); $2.000 .000 \mathrm{~m} 2$ em 1928 (RIO, 1928, p.32); 1.800 .000 m2 em 1954 (KLIASS, 1983, p.165) e atualmente tem $1.504 .000 \mathrm{~m} 2$, sendo $1.400 .000 \mathrm{~m} 2$ efetivamente cercados (SÂO PAULOb), é possível verificar-se uma perda em torno de trinta por cento de sua área programada, devida principalmente à administração municipal que nunca priorizou realmente a preservação das áreas verdes sob sua responsabilidade. Muitas áreas originais do lbirapuera estão hoje apropriadas pela União, Estado e particulares, devido à ação ou omissão do próprio poder público municipal. 


\subsubsection{Problemas observados}

O parque ressente-se até hoje pela ausência de um plano de manejo definido. Basta observar-se que até a década de 1920 pretendia-se loteá-lo para construir casas populares ou para servidores municipais. Houve através de sua história, a partir de 1929, pelo menos sete projetos urbanísticos para a área. E já se pretendeu implantar um hipódromo, um cassino e até um aeroporto no local.

O último dos projetos, de Niemeyer e equipe, foi parcialmente implantado, porém priorizou o aspecto arquitetônico em detrimento do paisagístico, para a instalação da Exposição do IV Centenário de São Paulo. Nele o verde serviria apenas de moldura para imensos espaços construídos, destinados a terem uso cultural após o final da exposição, sem que houvesse demanda para tanto na São Paulo da época. Ficou repleto de vias asfaltadas e áreas de estacionamento para atendimento dos visitantes da exposição. Como resultado posterior, o parque tornou-se um centro administrativo improvisado, com repartições públicas de todo o gênero, inclusive o gabinete do prefeito, cortado por trânsito intenso de veículos, intensamente impermeabilizado. Sem contar os usos indevidos de que foi vítima, como boate, parque de diversões privado, cemitério de animais, depósito de material escolar e até pocilga.

Desses equívocos de projeto e usos inadequados o parque ressente-se até hoje, apesar do cercamento por gradis, que suprimiu o trânsito interno de veículos, da retirada das repartições públicas de seu interior e da demolição de diversas edificações. Muitos dos antigos pavilhões de exposição ainda não têm usos culturais definidos. Mesmo assim, recentemente, foi construído mais um edificio, um auditório custeado por empresa de telefonia, sob a justificativa de que o projeto já estava previsto originalmente, sem levar em conta a mudança de usos e necessidades dos usuários do parque, passados quarenta e quatro anos da sua inauguração, o que resultou em remoção de árvores e aumento de impermeabilização do solo, apesar do Parque do Ibirapuera ser bem tombado. 
O gradeamento, por sua vez, não abrange toda a área do parque, que permanece cortado e envolvido por algumas vias de tráfego pesado que tornam o ar do local bastante poluído. Sem contar a poluição da água dos lagos, decorrente dos córregos que os abastecem e que data ainda da sua inauguração, agravando-se com o passar dos anos, sem solução à vista.

O Ibirapuera talvez seja a principal vítima da ausência de uma política pública e de governo realmente preocupada com a criação, conservação e utilização adequada de áreas verdes. A carência e má distribuição de áreas verdes pela cidade provoca a sobrecarga de usuários, cuja freqüência nos finais de semana chega a ser de 200 mil pessoas, com evidentes danos ambientais ao parque, entre os quais problemas sérios de tráfego e poluição. Sem contar que a grande maioria dessas pessoas espera usufruir do parque para respirar ar puro, inclusive para prática de exercícios físicos, sem ter a menor noção dos riscos à saúde que está correndo num dos locais mais poluídos por ozônio da cidade.

A tais fatos deve ser acrescido o excepcional prestígio e visibilidade adquiridos por tudo aquilo que ocorre no Ibirapuera. Assim todas as empresas de eventos e shows cobiçam o Ibirapuera para suas realizações, no que costumam contar com apoio da municipalidade, contribuindo para agravar ainda mais o excesso de utilização do parque.

As tentativas de acréscimo de áreas públicas estaduais e federais ao perímetro do parque, visando ampliá-lo, embora bem intencionadas, esbarram em erros graves cometidos pela própria administração municipal que cedeu áreas do parque para o Estado (Assembléia Legislativa, Ginásio Poliesportivo), União (quartéis do Exército) e particulares (Círculo Militar). Como também em erros cometidos pela administração estadual que pôs a perder terrenos de grande valor ambiental, alguns originalmente integrantes do Instituto Biológico, por cessões sem critério a órgãos institucionais e particulares, que em grande parte descaracterizaram a vegetação existente e criaram óbices jurídicos quase intransponíveis para sua recuperação. Mais uma vez a variável ambiental viu-se totalmente desprezada. 
Em síntese, o Parque do Ibirapuera foi vítima dos mesmos malefícios que atingiram os demais parques objeto de análise deste trabalho, porém num grau muito maior, haja vista suas dimensões, localização privilegiada e prestígio perante a população, como a área verde mais visitada de todas e um dos mais importantes símbolos da cidade.

4.7.5. Síntese dos problemas encontrados nos parques analisados

Foram os seguintes os problemas comuns identificados nos parques urbanos acima referidos:

(1) ausência de diretrizes de uso e gestão determinadas. Os objetivos do parque urbano variam de acordo com os interesses da administração municipal vigente, que, normalmente, não costuma dar prioridade às áreas verdes;

(2) descaracterização de suas finalidades (preservação ambiental, lazer, recreação, cultura), com implantação no interior de parques urbanos de usos incompativeis com a sua natureza, como utilização de suas áreas internas como avenidas, estacionamentos, boates, parques de diversão privados, repartições públicas;

(3) cessão de áreas para entidades públicas e privadas, que passam a ter finalidades alheias a um parque urbano, como obras viárias, quartéis, repartições públicas, clubes, associações. Deste fato resulta, geralmente, a destruição da cobertura vegetal dos espaços perdidos e a redução irrecuperável das dimensões do parque; 
(4) alternância entre períodos de boa administração e disponibilidade de . verbas $\mathrm{e}$ fases de abandono $\mathrm{e}$ indisponibilidade de recursos financeiros, ao talante do administrador público de plantão;

(5) descaso com o entorno dos parques, que se vêem cercados por edifícios excessivamente altos, frutos da especulação imobiliária, vias de trânsito pesado, que agravam os problemas de poluição do ar e sonora.

\subsection{PARQUE URBANO COMO UNIDADE DE CONSERVAÇÃO}

\subsubsection{Conceito}

Fazendo uma recapitulação, embora o rol do Sistema Nacional de Unidades de Conservação (SNUC) seja aparentemente exaustivo, é possivel aos Estados. Municípios e Distrito Federal criar categorias de unidades de conservação próprias, distintas, que podem ser sistematizadas ou não. Basta apenas que tais categorias possam ser enquadradas no conceito de unidade de conservação contido no art. $2^{\circ}$, inc. I, da Lei 9.985, de 18/07/2000 (Lei do SNUC). Os Estados, Municipios e Distrito Federal podem pleitear, caso desejem, o reconhecimento dessas categorias próprias junto ao CONAMA, com fulcro no art. $6^{\circ}$, $\S$ único da Lei do SNUC. Porém, mesmo que assim não façam, não estarão praticando nenhum ato ilegal ou inconstitucional. Inclusive, tais categorias próprias podem ser voltadas para o meio urbano, até porque os Estados, Municípios e Distrito Federal estarão exercendo sua competência constitucional supletiva, eis que o SNUC tratou apenas da preservação no âmbito rural (art. $24, \S \S 2^{\circ}$ e $3^{\circ}$; art. 30 , incs. I e II, da Constituição Federal). 
A partir deste fundamento, os parques urbanos podem ser tratados juridicamente como unidades de conservação. E deveriam, já que este regime jurídico, de acordo com nosso entendimento, pode ser de grande utilidade para frear as barbaridades que historicamente são praticadas contra as áreas verdes em nosso país.

Sendo assim, podemos esboçar e propor um conceito de parque urbano, como unidade de conservação:

\begin{abstract}
"O parque urbano é uma unidade de conservação situada em área urbana ou de expansão urbana, de posse e domínio público, dotada predominantemente de vegetação nativa e/ou exótica, devidamente cercada, que tem por objetivo básico a preservação ambiental em harmonia com a prática de atividades de lazer, educativas e culturais, para as quais deve dispor de equipamentos adequados."
\end{abstract}

Dado o conceito, passamos a justificar seus pontos fundamentais:

Unidade de conservação: aplica-se ao parque urbano o conceito genérico de unidade de conservação contido no inc. I do art. $2^{\circ}$ da Lei do SNUC. Segundo tal dispositivo, unidade de conservação é definida como espaço territorial e seus recursos ambientais, incluindo as águas jurisdicionais, com características naturais relevantes, legalmente instituído pelo poder público, com objetivos de conservação e limites definidos, sob regime especial de administração, ao qual se aplicam garantias adequadas de proteção.

Sua criação é efetuada por ato do poder público. Tal criação deve ser precedida de estudos técnicos e de consulta pública que permitam identificar a localização, a dimensão e os limites mais adequados para a unidade (art. 22 da Lei do SNUC).

Pode-se levantar algum óbice quanto à aplicação da expressão “características ambientais relevantes" a um parque como o do Ibirapuera, cuja cobertura arbórea é na maior parte formada de eucaliptos. Ora, tal conceito deve ser visto de um ponto de vista relativo. Realmente, se imaginarmos o Parque do Ibirapuera no contexto do Parque Estadual da Serra do Mar, por exemplo, com sua 
exuberante flora e fauna nativas, seu interesse ambiental seria praticamente irrelevante. Mas no contexto da selva de concreto paulistana em que realmente se situa, sua relevância ambiental, social e cultural é incontestável. Sem contar que o Ibirapuera, por exemplo, serve de habitat para pelo menos cento e doze espécies de aves (SÃO PAULOb).

Existem precedentes legais considerando parques urbanos como unidades de conservação, observáveis em normas das esferas estadual e municipal. Assim, o Sistema Estadual de Unidades de Conservação da Bahia, criado pela Lei 10.431 de 10/12/2006, reconhece o parque urbano como unidade de conservação de uso sustentável (SOCIEDADE MUNDIAL DE PROTEÇÃO ANIMAL, 2006). O Sistema Municipal de Unidades de Conservação de Curitiba, criado pela Lei 9.804 de 03/01/2000, considera o parque urbano como unidade de conservação, sem classificação específica, sob a denominação de parques e bosques de lazer, que diferem um do outro apenas por questão de dimensões (CURITIBA, 2000). Já o Sistema Municipal de Unidades de Conservação de Goiânia, ainda em projeto, cria um grupo específico de unidades de conservação, mesmo que não sejam oficialmente denominadas como tal, com o nome de parques urbanos (GOIÂNIA). A Lei Municipal de São Paulo 13.539, de 20/03/2003, ao criar os conselhos gestores dos parques urbanos municipais, em seu art. $8^{\circ}$, inc. II, declara como atribuição desses órgãos colegiados, entre outras, a de propor medidas visando "a consolidação de seu papel [do parque urbano] como centro de lazer e recreação e como unidade de conservação e educação ambiental" (SÃO PAULO, 2003) (grifos nossos)

O próprio Atlas Ambiental do Município de São Paulo reconhece que os parques urbanos cumprem as mais variadas funções "constituindo-se desde importantes áreas de lazer até significativas áreas de preservação de vegetação nativa, banco genético e refúgio para a fauna urbana, podendo ser considerados unidades de conservação" (SÃO PAULO, 2004, p.100) (grifos nossos).

O Plano Diretor Estratégico do Município de São Paulo (Lei 13.430 de 13/09/2002), embora não considere os parques urbanos como unidades de conservação, procura aproximá-los dos conceitos do SNUC, ao classificá-los, 
juntamente com as praças públicas, como áreas verdes de uso sustentável (art. 132, inc. II, letra f). Essa aproximação também ocorre pela criação de conselhos gestores para atuarem nos parques urbanos, por meio da Lei Municipal 13.539 de 20/03/2003.

Sendo o parque urbano uma unidade de conservação, deve ele ser considerado de proteção integral ou de uso sustentável? Seria melhor que ele pertencesse a uma categoria própria, tendo em vista suas características especificamente urbanas. Assim, tal categoria poderia denominar-se "unidade de . conservação do meio ambiente urbano". Ou na pior das hipóteses, poderia ser considerado como uma unidade de proteção integral, cujo objetivo básico é a preservação ambiental, onde só se admite o uso indireto de seus recursos naturais, isto é, aquele que não envolve consumo, coleta, dano ou destruição destes recursos (art. $7^{\circ}, \S 1^{\circ}$, c.c. art. $2^{\circ}$, inc. IX da Lei do SNUC).

Portanto, parecem-nos equivocadas as classificações do Sistema Estadual de Unidades de Conservação da Bahia e do Plano Diretor Estratégico do Município de São Paulo que consideram o parque urbano como de uso sustentável. Isto é, consideram possível o uso direto de seus recursos naturais, que envolve coleta e uso, comercial ou não de tais recursos (art. $2^{\circ}$, inc. $X$ da lei do SNUC). Este uso direto, em parque urbano, é inadmissível. Seria verdadeira aberração aceitar-se, por exemplo, o manejo, mesmo que sustentável, da madeira dos eucaliptais integrantes do Parque do Ibirapuera e do Parque da Aclimação para comercialização.

Em área urbana ou de expansão urbana: uma área passa a ter qualificação urbana quando ordenada para cumprir destino urbanístico, especialmente a edificabilidade (edificações públicas e privadas), a vialidade (de sistema viário) e as atividades de recreação (áreas verdes, praças de esporte, etc.), que não são, por natureza, qualidades do solo (SILVA, 2006, p.82, 180-181). Como complementa García de Enterría, o destino cria uma utilidade legal que pode aproveitar ao proprietário e que se contrapõe à utilidade natural dos terrenos rústicos (apud SILVA, 2006, p.82). Zona de expansão urbana, por sua vez, é aquela destinada ao crescimento ordenado das cidades, vilas e povoados, contígua ou não ao perímetro urbano, abrangendo as áreas previstas para ocupação humana num periodo 
determinado, com base nas taxas de crescimento populacional, nos programas de urbanificação, de investimentos ou ainda em projetos de natureza especial (SILVA, 2006, p.176).

A utilização simultânea das expressões “área urbana” e "área de expansão urbana", pressupõe que os parques urbanos venham a ser criados não apenas nas áreas de urbanização consolidada, com também naquelas para as quais se preveja a expansão urbana.. Aliás, a reserva de áreas periféricas para a implantação de parques urbanos, antes da chegada da urbanização propriamente dita, pode tornar-se um excelente instrumento para ampliação das áreas verdes, a custos bem mais reduzidos.

De posse e domínio público: é possível, em tese, a existência de parques urbanos privados. Porém não nos parece ser essa a solução mais adequada para a realidade urbana brasileira, onde prevalece a reserva de terrenos pelos seus proprietários para fins exclusivamente especulativos. São Paulo, por exemplo, já teve, entre outros parques particulares, o Parque Antártica, o Bosque da Saúde, a Granja Julieta, que por algum tempo foram espaços importantes de lazer para a população e que terminaram impiedosamente loteados, quando desapareceu o interesse dos proprietários privados em mantê-los. O interesse desses proprietários, no geral, era criar um atrativo que valorizasse a região. Obtida a valorização, estava na hora de efetuar o loteamento da área, incluindo o próprio parque.

- Caso os particulares desejem criar unidades de conservação particulares urbanas, talvez fosse o caso de implantarem Reservas Particulares do Patrimônio Natural, a exemplo do que ocorre em Curitiba.

Dotada predominantemente de vegetação nativa e/ou exótica: o verde, a vegetação constitui-se no aspecto básico do conceito. Caso contrário, teriamos apenas arborização, como em alamedas e avenidas, onde a vegetação é acessória, embora também muito importante (SILVA, 2006, p.278-279). Nesse sentido, o Plano Diretor Estratégico do Município de São Paulo é bem explícito quanto às áreas verdes, ao prever que no mínimo sessenta por cento de suas áreas totais deve ser livre e destinada à implantação e preservação de ajardinamento e arborização (art. 136, § 
$5^{\circ}$, da Lei 13.430/2002). Quanto à qualidade de vegetação, poderá ser ela nativa ou exótica, desde que seja em quantidade. Nas cimentadas e impermeabilizadas cidades brasileiras, cada árvore, cada arbusto, cada espaço gramado que se preserva, constitui-se em ganho ambiental respeitável.

Devidamente cercada: a experiência demonstra que sem o necessário cercamento, seja por gradil ou tela, o parque fica exposto a todo o tipo de dano decorrente de sua situação urbana. Assim, fica ele sujeito à depredação da fauna, flora e equipamentos, invasões, à freqüência indesejada de marginais, ao uso de sua área como depósito de lixo e entulho, ponto de uso de drogas e prostituição, desmanche clandestino de veículos, etc. Em suma, torna-se um local degradado, perigoso, inadequado à preservação ambiental, que afasta os freqüentadores, deixando assim de cumprir os objetivos que justificam sua criação. Em São Paulo temos os exemplos dos Parques da Luz e do Ibirapuera, cujo acelerado processo de degradação somente começou a ser freado a partir da colocação de grades em suas divisas. As áreas remanescentes do Ibirapuera, que ainda hoje não estão cercadas, são as mais deterioradas.

Tem como objetivo básico a preservação ambiental: como toda a unidade de conservação. Deve-se destacar que a vegetação tem funções essenciais dentro de uma cidade. E a sua preservação, na forma de parques urbanos, é fundamental para garantir a qualidade de vida da população urbana sob todos os aspectos, especialmente no que tange à sua saúde física, social e psíquica.

Em harmonia com a prática de atividades de lazer, educativas e culturais: segundo Dumazedier (apud LIMA, 2007, p.02), lazer é um conjunto de ocupações às quais o indivíduo pode entregar-se de livre vontade, seja para repousar, seja para divertir-se, recrear-se e entreter-se, ou ainda, para desenvolver sua informação ou formação desinteressada, sua participação voluntária ou sua livre capacidade criadora, após livrar-se ou desembaraçar-se das obrigações profissionais, familiares ou sociais. Já de acordo com CAMARGO (2003, p.97), lazer é um conjunto de atividades gratuitas, prazerosas, voluntárias e liberatórias, centradas em interesses culturais, físicos, manuais, intelectuais, artísticos e associativos, realizadas num 
tempo livre roubado ou conquistado historicamente sobre a jornada de trabalho profissional e doméstico e que interferem no desenvolvimento pessoal e social dos indivíduos.

Como expressa LIMA (2007, p.03), o conceito de lazer é muito amplo, pois qualquer atividade pode ser considerada lazer se proporcionar prazer, desenvolvimento a quem pratica. Pode até ser a não-atividade, o ócio, o descanso físico. Até uma atividade profissional ou uma obrigação torna-se lazer para quem gosta e faz apenas para se divertir e relaxar.

Destarte, a palavra lazer contida no conceito abrange toda a série de atividades recreativas, contemplativas, esportivas, sociais, de assistência de espetáculos e concertos, festejos, visitação a museus, entre outras que os usuários praticam ou podem praticar dentro de um parque urbano, dependendo da infraestrutura nele disponível.

Além do mais, o direito ao lazer é direito social reconhecido pela Constituição Federal (art. $6^{\circ}$ ). O lazer ainda é arrolado entre as necessidades vitais básicas do trabalhador e sua família (art. $7^{\circ}$, inc. IV da Constituição Federal) e deve ser incentivado pelo poder público, como forma de promoção social (art. $217, \S 3^{\circ}$, Idem).

Especificamos também as atividades educativas, porque estas poderão ser praticadas como dever escolar e profissional, e não apenas como lazer. Estas atividadẹs incluem não somente a educação ambiental, mas também a de eventuais cursos de extensão que venham a ser realizados, como ocorre, por exemplo, no caso do Prospect Park, no Brooklyn, Nova York (WALKER, p.03).

No que tange à educação ambiental, por sua natureza integradora, pois permeia inúmeras áreas do conhecimento, pode ser trabalhada dentro dos mais variados contextos. Entre eles, destacam-se as atividades realizadas em áreas que permitem um contato direto com a natureza, como o estudo do meio e trilhas interpretativas efetuadas em unidades de conservação. A realização dessas atividades como instrumento para o desenvolvimento da educação ambiental não deve ocorrer de 
forma pontual e caracterizada apenas pelos aspectos ecológicos. É necessário qué ocorram como atividades permanentes, que enfatizem também aspectos econômicos, sociais, políticos, culturais e éticos, abrindo um espaço para a geração de novos valores de respeito aos seres humanos e à vida (TOLEDO e PELICIONI, 2005, p.753).

A referência específica às atividades culturais, vem da ênfase que se deve dar à presença humana nesse tipo de unidade de conservação. $O$ que contrasta diretamente com as características das unidades de conservação do SNUC, especialmente as de proteção integral, onde a presença humana deve ser, na maior parte dos casos, restrita e controlada.

Quando falamos aqui em atividades culturais, estamos tratando daquelas tipicamente humanas em geral. Como expressa CRESPO (2000, p.176), a cultura é definida como o conjunto organizado dos vários modos de vida de uma sociedade; ela resultaria da forma de ser dos homens. Segundo Hegel, (apud CRESPO, Idem), a cultura estaria especificamente relacionada com as formas como os homens vão compreendendo, representando e se relacionando com os vários elementos componentes da sua existência: trabalho, religião, linguagem, ciências, artes, política.

Obviamente, para tais práticas, o parque urbano deve dispor de equipamentos adequados.

Quanto às dimensões de um parque urbano, preferimos não fazer menção no conceito, tendo em vista as divergências a respeito existentes entre os vários autores que tratam do tema. Essa verdadeira confusão conceitual é especialmente observada na realidade dos parques urbanos brasileiros. Em São Paulo, por exemplo, existem parques como o Anhangüera, de 950 hectares e o Ibirapuera, com 158,40 hectares ao lado de outros como o Buenos Aires, com 2,5 hectares e o Lina e Paulo Raia (antigo Conceição), com 1,5 hectare (BARTALINI, 1999, p.151). Recentemente, a prefeitura municipal anunciou a criação de um parque urbano num terreno da avenida Paulista, com remanescentes de vegetação nativa, cuja área é de apenas 0,54 hectare (GALVÃO, 2008, p.C8). Além disso, devido à subjetividade com que internacionalmente se quantifica o tamanho dos espaços livres, é que LIMA 
et al (1994, p.548) recomendaram a realização de estudos aprofundados para elucidar esta questão.

\subsubsection{Regime jurídico}

O mais importante não é conferir ao parque urbano o mero rótulo formal de unidade de conservação. O fundamental é a aplicação ao parque urbano do regime jurídico próprio das unidades de conservação, no que couber, com a finalidade de garantir a sua proteção e o exercício adequado de suas funções sócio-ambientais no meio artificial ou urbano.

São institutos jurídicos característicos das unidades de conservação aplicáveis aos parques urbanos: o conselho gestor, o plano de manejo, a zona de amortecimento, os corredores ecológicos, a gestão compartilhada com organização da sociedade civil de interesse público (OSCIP).

\subsubsection{Conselho gestor}

Nas palavras de MACHADO (2005, p.152), os colegiados visam, na pureza da sua conceituação, inventariar as opiniões dos setores que têm interesse na matéria a ser tratada. Colhem-se idéias e informações, confrontando-se as mesmas em busca da formação de uma posição comum, ou pelo menos, de uma posição majoritária. Shaefer, apud MACHADO (2005, p.152), salienta a vantagem de uma larga participação no organismo colegiado, afirmando que as pessoas se sentem mais incorporadas à decisão finalmente adotada, mesmo que a escolha realizada pela 
instância responsável não seja exatamente aquela da preferência da maioria dos participantes. A tomada de decisão participativa pode ser considerada como um verdadeiro antídoto contra a apatia dos agentes de participação.

A presença de órgãos colegiados atuando na gestão de unidades de conservação constitui-se em importante inovação da Lei do SNUC, perfeitamente aplicável ao parque urbano. Tal iniciativa garante maior transparência e fiscalização sobre a gestão das unidades de conservação, além de possibilitar a participação e o envolvimento responsável da sociedade civil (RODRIGUES, 2005b, p.110).

Tem-se aqui uma manifestação clara do princípio da participação, princípio geral do direito ambiental expresso no art. 10 da Declaração do Rio de Janeiro, da Conferência das Nações Unidas para o Meio Ambiente e o Desenvolvimento de 1992: o melhor modo de tratar as questões do meio ambiente é assegurando a participação de todos os cidadãos interessados no nível pertinente (MACHADO, 1994, p.39).

Apesar de ser compulsória, a atuação do Estado para a proteção do meio ambiente não é exclusiva, pois a participação popular é fundamental no processo de gestão urbano-ambiental. Esta participação pode efetivar-se de várias formas: iniciativa popular no processo de criação legislativa, participação em audiências públicas e referendos populares, participação em órgãos colegiados, etc. (SILVEIRA e SOUZA, 2007, p.168).

No confronto entre o desenvolvimento econômico e a preservação ambiental, assim como na incorporação de custos ambientais e na formulação de políticas públicas adequadas à conservação da natureza, a participação popular é indispensável. A sociedade moderna não mais admite a figura do Estado-pai, tutor de todos os interesses e capaz de dar respostas a todos os anseios da sociedade. Nos dias de hoje, são fundamentais a organização, a mobilização e a participação ativa da sociedade civil no debate dos grandes temas de interesse coletivo. A cidadania é fundamento do Estado democrático e de direito, representando a pedra angular de toda a construção da sociedade. A Constituição Federal destaca, já em seu artigo 
primeiro, o dever do Estado de assegurar o exercício dos direitos individuais e coletivos, entre outros (SOUZA, 2007, p.167).

$\mathrm{Na}$ democracia, quanto mais ampla e generalizada for a participação popular, mais legítima e democrática é a política pública adotada. A escolha e o procedimento da política pública é atribuição do governo, bem como a sua implementação e responsabilidade. Mas a sociedade civil deve participar efetivamente da construção do processo de políticas públicas. O verdadeiro sentimento da democracia alia-se à cidadania, que é a efetiva participação nos negócios do Estado. O cidadão pleno deve participar da seleção das políticas públicas e não simplesmente votar em eleições (SIQUEIRA JR. e OLIVEIRA, 2007, p.251).

Frydman e Haarscher (apud MACHADO, 2006, p.34-35) acentuam que a vida democrática não se limita às instituições representativas. A opinião pública deve dispor de um poder permanente de crítica, de influência e de controle dos governantes. Os atores da sociedade civil que animam o debate político, como as associações e os movimentos, assim também os intelectuais e os jornalistaș, cumprem, desse ponto de vista, uma missão importante, na medida em que contribuem para informar e mobilizar a opinião, estruturar as tomadas de posição e, finalmente, tornar audíveis as reivindicações dos cidadãos perante os governantes.

A abertura de espaços de participação pode, efetivamente, facilitar a obtenção de respostas para as demandas comunitárias, ampliar a comunicação entre governantes e governados, fornecer melhores parâmetros para a tomada de decisões e, nessa medida, fortalecer a gestão pública e promover a expansão da cidadania ativa (NOGUEIRA, 2005, p.142-143).

A noção de conselho gestor presente no ordenamento jurídico brasileiro busca torna-lo espaço público jurídico-institucional privilegiado de intervenção social planejada na formulação e implantação de políticas públicas. Neste, todas as demandas soam legítimas por princípio, prevendo-se canais de confronto e interpelação democráticos entre os projetos sociais, a fim de possibilitar a construção de alternativas viáveis (LOUREIRO, 2003, p.113). 
O fato de os conselhos gestores serem uma forma de participação e de democracia mais direta, reconhecida pela Constituição Federal, representa uma inequívoca vitória dos movimentos sociais, das forças populares e da sociedade civil organizada no processo de democratização do Estado brasileiro. A existência de desvios de propósito, de conselhos burocráticos e manipulados por determinado grupos ou esvaziados politicamente, não invalida a conquista e sim manifesta o modo como se formou o Estado e como o exercício da cidadania foi negado ao longo da história. Cumpre entender que a busca de canais democráticos de participação no país não significa substituição ou sobreposição em relação à democracia representativa e sua institucionalidade, mas ações complementares que reforçam, ampliam, reestruturam e consolidam esse regime político entre nós. Os conselhos não são uma espécie de panacéia política e cultural, mas uma possibilidade a ser considerada na promoção da cidadania (LOUREIRO, 2003, p.114).

Esse reconhecimento jurídico dos conselhos de unidades de conservação é essencial para tornar efetivas as suas decisões. É o oposto do que ocorre com outros institutos, como a Agenda 21. Como afirma MELLO (2006, p.76), os promotores da Agenda 21 crêem que ela seria capaz de atuar em áreas tais como planejamento dos serviços básicos, determinação de prioridades no orçamento, funções tradicionalmente exercidas pelos políticos eleitos e administração pública em geral. Não há, porém, mecanismos concretos através dos quais o governo eleito e a administração deverão incorporar as deliberações dos participantes do Fórum 21. Em outras palavras, dada a ausência de instrumentos que garantam a participação, contase apenas com a boa-fé dos governantes e com o seu interesse em, efetivamente, apoiar e implementar políticas participativas.

Merece destaque o esforço louvável do Município de São Paulo que criou os conselhos gestores dos seus parques urbanos, pela Lei Municipal 13.539 de 20/03/2003 (SÃO PAULO, 2003).

Feitas essas considerações preliminares, passamos a oferecer uma proposta de estruturação, composição e funcionamento de conselhos gestores de parques urbanos, tendo como subsídios as disposições a respeito da Lei 9.805 de 
18/07/2000 (Lei do SNUC), do Decreto 4.340, de 22/08/2002 (Regulamento da Lei do SNUC) e da citada Lei Municipal de São Paulo 13.539 de 20/03/2003.

Pelo que determina a Lei do SNUC, cada unidade de conservação de proteção integral deve ter um conselho consultivo, presidido pelo órgão responsável por sua administração e constituído por representantes de órgãos públicos, de organizações da sociedade civil, por proprietários de terras localizadas em refúgio de vida silvestre ou monumento natural, quando for o caso, e representantes das populações tradicionais que nela residam, até que ocorra o seu reassentamento (art. 29 c.c. o $\S 2^{\circ}$ do art. 42 da Lei do SNUC).

Uma vez que os parques urbanos têm características próximas às das unidades de conservação de proteção integral, embora não seja o caso de se falar em populações tradicionais nem em proprietários de terras em seu interior, parece-nos que o conselho gestor proposto deve ter composição e funções análogas ao conselho consultivo. Porém, entendemos que devem ser acrescidas também algumas funções deliberativas para permitir uma maior eficiência participativa, como abaixo se verá.

A composição dos conselhos gestores deve ser paritária, com metade de seus membros representando o pọder público e a outra metade representando a sociedade civil (elaboração a partir do $\S 3^{\circ}$ do art. 17 do Regulamento do SNUC). Esta representação paritária é essencial para que a participação da sociedade civil seja real. Como afirmam OLIVEIRA e GUIMARÃES (2004, p.107), se o governo é o detentor da maioria de votos, a participação do cidadão nos órgãos colegiados serve apenas para legitimar as decisões tomadas.

A representação do poder público no conselho gestor, presidido pelo responsável por sua administração, deve contemplar os órgãos ambientais, preferencialmente das três esferas da federação e órgãos de áreas afịns, tais como pesquisa científica, educação, cultura, turismo, paisagem, arquitetura. No caso do parque urbano ser tombado, representante do órgão de preservação responsável deve integrar necessariamente o conselho (elaboração a partir do $\S 1^{\circ}$ do art. 17 do 
Regulamento do SNUC e do art. $2^{\circ}, \S 2^{\circ}$ da Lei Municipal de São Paulo $13.539 / 2003)$.

A representação da sociedade civil deve contemplar a comunidade científica, organizações não-governamentais ambientalistas com atuação comprovada no Município onde se situa o parque urbano, representantes dos usuários, moradores e setor privado atuante na região. A OSCIP com representação no conselho gestor não pode se candidatar e exercer sua gestão compartilhada (elaboração a partir dos $\S \S 2^{\circ}$ e $4^{\circ}$ do art. 17 do Regulamento do SNUC).

Destarte, deve competir ao conselho gestor funções consultivas e deliberativas como segue: (1) acompanhar a elaboração, implementação e revisão do plano de manejo quando couber; (2) participar da elaboração e aprovar o planejamento das atividades desenvolvidas pelos parques urbanos; (3) propor medidas visando a organização e a manutenção dos parques urbanos, a melhoria do sistema de atendimento aos usuários e a consolidação de seu papel como centro de lazer e recreação, além de unidade de conservação e educação ambiental; (3) analisar e opinar sobre pedidos de autorização de uso dos espaços dos parques municipais, inclusive para realização de shows e eventos; (4) fiscalizar e opinar sobre o funcionamento dos parques municipais; (5) buscar a integração do parque urbano com as demais unidades de conservação e espaços territoriais especialmente protegidos e com o seu entorno; (6) esforçar-se para compatibilizar e articular os interesses dos diversos segmentos sociais relacionados com o parque urbano; (7) avaliar o orçamento do parque urbano e o relatório financeiro anual, em relação aos objetivos do parque urbano; (8) opinar quanto à contratação e os dispositivos do termo de parceria, no caso de gestão compartilhada com OSCIP, na hipótese de gestão compartilhada do parque urbano; (9) acompanhar a gestão por OSCIP e recomendar a rescisão do termo de parceria quando constatada alguma irregularidade; (10) manifestar-se sobre obra ou atividade potencialmente causadora de impacto no parque urbano, zona de amortecimento ou corredores ecológicos; (11) propor diretrizes e ações para compatibilizar, integrar e otimizar a relação com os seus freqüentadores e a população do entorno; (12) examinar propostas, denúncias e 
queixas encaminhadas por qualquer pessoa ou entidade e a elas responder (elaboração a partir do art. 20 e incisos. do Regulamento do SNUC e do art. $8^{\circ} \mathrm{e}$ incisos da Lei Municipal de São Paulo 13.539/2003 ).

O mandato dos conselheiros deve ser de dois anos, permitida recondução. A função de membro do conselho gestor não será remunerada e considerada atividade de relevante interesse público (elaboração a partir do $\S 5^{\circ}$ do art. 17 do Regulamento do SNUC).

As reuniões dos conselhos gestores devem ser efetuadas ordinariamente, uma vez por mês, podendo as reuniões ser convocadas extraordinariamente, por solicitação de no mínimo cinqüenta por cento de seus membros, ou por seu presidente (elaboração a partir do art. $7^{\circ}$ da Lei Municipal de São Paulo $13.539 / 2003)$.

Cada parque urbano deve ter o seu conselho gestor. Porém, no caso dos municipios menores que vinte mil habitantes, onde o plano diretor não é obrigatório (art. 182, $\S 1^{\circ}$ da Constituição Federal), o Conselho Municipal de Defesa do Meio Ambiente, ou órgão equivalente, cuja composição inclua representantes do poder público e da sociedade civil de forma paritária e com competências que incluam as acima referidas, pode ser designado como conselho gestor de parque urbano (elaboração a partir do $\S 6^{\circ}$ do art. 17 do Regulamento do SNUC).

As atividades do conselho gestor devem ser assessoradas por um órgão executor, ao qual cabe a convocação das reuniões com antecedência mínima de sete dias, de acordo com normas que podem constar de seu regimento interno, como também prestar apoio aos conselheiros nas reuniões (elaboração a partir do art. 19, incs. I e II do Regulamento do SNUC). O órgão executor deve dar especial atenção à pauta, a ser previamente informada aos conselheiros, bem como ao fornecimento das informações que se façam necessárias para bem esclarecer os membros do colegiado e embasar seus posicionamentos. Não se deve olvidar, como bem coloca LEITE (2000, p.40), que a participação sem informação adequada não é credível nem eficaz, mas um mero ritual. 
- As deliberações do colegiado devem ser públicas no decorrer da sessão; ou, após a manifestação consultiva ou deliberativa, os votos deverão ser tornados públicos. Disso depende a possibilidade dos administrados se inteirarem da maneira como as decisões foram tomadas e terem a oportunidade de elogiar ou criticar o posicionamento dos que devem zelar pelos seus interesses (MACHADO, 2005, p.151).

\subsubsection{Plano de manejo}

O plano de manejo é um documento técnico mediante o qual, com fundamento nos objetivos gerais de uma unidade de conservação, se estabelece o seu zoneamento e as normas que devem presidir o uso da área e o manejo dos recursos naturais, inclusive a implantação das estruturas físicas necessárias à gestão da unidade (ar. $2^{\circ}$, inc. XVII da lei do SNUC). Toda unidade de conservação deve ter seu plano de manejo (art. 27, caput, da mesma lei). Este plano de manejo deve abranger toda a área da unidade; regular sua zona de amortecimento quando existente; regular os corredores ecológicos, quando previstos; incluir medidas para promover a sua integração à vida econômica e social das comunidades vizinhas (art. $27, \S 1^{\circ}$ do mesmo diploma legal).

O plano de manejo de um parque urbano deve partir de premissas um pouco diferentes daquelas utilizadas nos casos das unidades de conservação de proteção integral do SNUC. Nestas, a preservação da natureza é o objetivo principal e a presença humana, senão completamente excluída, deve ser ao menos restringida e controlada. No caso dos parques urbanos, geralmente o meio natural foi recriado pela mão humana, ou apresenta um grau menor de preservação, pela forte influência antrópica típica do meio urbano. Neles a presença humana deve ser incentivada, em atividades de lazer, educação e cultura, em harmonia com a natureza. 
DUARTE (2002, p.08), ao tratar de parques urbanos lisboetas, traça algumas considerações que devem ser levadas em conta nos planos de manejo. Segundo esta autora, a criação de um parque urbano introduz um valor que se acrescenta à vida da comunidade e que este valor será tanto maior, quanto maior for a ênfase colocada na participação pública e na oferta de uma experiência cultural, didática e onírica, dirigida ao público em geral, para além de um cenário que recrie na cidade trechos da paisagem natural e que ofereça equipamento de recreio ativo e infantil.

Ainda segundo DUARTE (2002, p.08-09), a natureza é o aspecto do parque urbano que produz um maior fascínio e envolvimento afetivo do público. Mas contatar a natureza normalmente não é o principal motivo para a visita ao parque. $\mathrm{A}$ utilização do parque urbano deve-se à existência de características que são percebidas como positivas e valorizadas pela população: beleza, segurança e qualidade de manutenção. No parque urbano as zonas mais utilizadas são as que possuem equipamento de suporte de atividades recreativas e locais de estadia confortável. A vitalidade social do parque urbano é dada pelo uso e este depende da qualidade percebida no ambiente e do significado atribuído à experiência do lugar.

Como afirma JACOBS (2000, p.97), os parques urbanos, ou espaços similares, são comumente considerados uma dádiva conferida à população carente das cidades. Mas na verdade, deve-se imaginar que os parques urbanos é que são locais carentes que precisam da dádiva da vida e da aprovação conferida a eles. Isso está mais de acordo com a realidade, pois as pessoas dão utilidade aos parques e fazem deles um sucesso, ou então não usam e os condenam ao fracasso. Espera-se muito dos parques urbanos. Longe de transformar qualquer virtude inerente ao entorno, longe de promover as vizinhanças automaticamente, os próprios parques urbanos é que são direta e drasticamente afetados pela maneira com que a vizinhança neles interfere (JACOBS, 2000, p.104).

JACOBS (2000, p.112) enxerga quatro características nos projetos de parques que costumam ser bastante utilizados pela população: complexidade, centralidade, insolação e delimitação espacial. 
A complexidade diz respeito à multiplicidade de motivos que as pessoas têm para freqüentar os parques urbanos. Uma pessoa pode ir a um parque por motivos diferentes e em horários diferentes. Se o espaço puder ser apreendido num relance e se cada um de seus segmentos for igual aos outros e transmitir a mesma sensação em todos os lugares, o parque será pouco estimulante para usos e estados de espírito diversificados. Nem haverá motivos para freqüentá-lo várias vezes. A complexidade que está em jogo não é a do desenho, mas a complexidade visual, mudanças de nível no piso, agrupamento de árvores, espaços que abrem perspectivas variadas. Em resumo, diferenças sutis da paisagem, que são acentuadas pelos diferentes usos que nela proliferam. Os parques bem sucedidos sempre parecem mais complexos quando estão em uso do que quando estão vazios (JACOBS, 2000, p.112-113).

O elemento mais importante da complexidade, segundo JACOBS (2000, p.114), talvez seja a centralidade. Os parques pequenos e bons geralmente têm um lugar reconhecido por todos como sendo o centro, no mínimo um cruzamento principal e ponto de parada, num local de destaque. Certos parques e praças pequenas são quase que unicamente um centro; sua complexidade decorre de diferenças menores na periferia. As pessoas esforçam-se para criar um local de destaque nos parques. Mas às vezes é impossível, como em parques que são uma faixa longa e padronizada, cujo desenho parece ter saído de uma estamparia de tecidos. Ande de um lado ou do outro, nesse tipo de parque, o freqüentador tem a impressão de sempre estar monotonamente no mesmo lugar.

O sol faz parte do cenário de um parque para pessoas, obviamente que sob uma sombra no verão. Um edifício alto que corte a passagem da luz solar de um dos lados do parque pode comprometê-lo (JACOBS, 2000, p.115). A autora cita o exemplo de uma praça que tem muitas qualidades, mas que em determinada época do ano, fica com um terço de sua área vazia; o manto da sombra de um grande edifício funciona como um enorme apagador de seres humanos (JACOBS, Idem). Daí a importância de se zelar pelo entorno (zona de amortecimento) do parque urbano de modo a garantir a insolação e impedir a excessiva verticalização, que pode tornar regiões do parque sombrias e prejudicar também a vegetação, além dos visitantes. E 
essa missão torna-se especialmente árdua, na medida em que os parques urbanos costumam ser pólos atrativos para a especulação imobiliária.

Embora não devam tirar o sol dos parques, desde que a meta seja encorajar o seu uso, a existência de construções em volta deles é importante para os projetos. Elas os envolvem. Criam uma forma delimitada de espaço, de modo que ele se destaca como um elemento importante no cenário urbano, um elemento positivo e não um excedente supérfluo. Em vez de se sentirem atraídas por pedaços indefinidos de terreno que sobram à volta de edifícios, as pessoas agem como se fossem repelidas por eles. Os freqüentadores de parques urbanos não procuram um cenário feito para os edifícios; eles buscam um cenário feito para eles mesmos. Para eles, os parques devem constituir o primeiro plano e não apenas o pano de fundo (JACOBS, 2000, p.115-116). Como se vê, a autora apresenta uma crítica contundente, embora não explícita, ao urbanismo modernista e sua concepção de edificações envolvidas indistintamente por áreas verdes.

A partir dessas considerações que devem ser levadas em conta na elaboração do plano de manejo, passamos a sugerir o seu conteúdo mínimo, tendo em vista as características do parque urbano. Estas sugestões são inspiradas nas disposições a respeito da Lei do SNUC, seu Regulamento e nas exigências do plano de manejo da reserva do patrimônio particular natural municipal de Curitiba, tendo em vista o seu caráter eminentemente urbano, conforme RIBEIRO (2008, p.11-14).

O plano de manejo deve definir e caracterizar o seu entorno. Para tanto, esse entorno precisa ser delimitado e efetuado um levantamento das suas características ambientais, socioeconômicas e de infra-estrutura. A partir desses dados, deve-se levantar os impactos positivos e negativos que seriam causados pelo parque urbano na região em que está ou será implantado.

Esse levantamento é fundamental para definir a população usuária, efetiva e potencial do parque; para a definição da zona de amortecimento e sobre a possibilidade de implantação de corredores ecológicos; para a definição de ações mitigatórias dos impactos negativos porventura existentes. 
Deve ser caracterizada a área de inserção do parque urbano. Para tanto é preciso traçar o perfil socioeconômico dos freqüentadores e verificar suas opiniões, necessidades e anseios quanto ao parque. Há que se fazer o levantamento topográfico, hídrico, faunístico e florístico do local, além da caracterização dos seus aspectos históricos e culturais, bem como das construções e equipamentos existentes. Ainda devem ser especialmente caracterizadas as edificações de valor cultural, os acervos dos museus, monumentos, obras de arte e sítios arqueológicos eventualmente existentes na área. Todos estes levantamentos devem ser ilustrados com plantas, gráficos, mapas e fotos.

$\mathrm{Na}$ etapa de planejamento, deve ser realizado o zoneamento da área. Zoneamento é o resultado de um projeto dinâmico em que, utilizando-se técnicas de planejamento ecológico, é possível caracterizar zonas e propor seu desenvolvimento físico-territorial de acordo com certas finalidades previstas e diretrizes básicas para o manejo da unidade. $\mathrm{O}$ zoneamento inclui também restrições como estímulos locais para atividades capazes de influir sobre o meio ambiente (PHILIPPI JR. et al, 2005, p.646). Destarte, pode-se sugerir alguns tipos de zonas, embora sua denominação e utilização possa variar, de acordo com as características de cada parque urbano.

(I) Zona intangível: aquela onde a primitividade da natureza permanece intacta, ou tenha ocorrido pequena ou mínima interferência humana. É destinada à preservação, com visitação restrita apenas à pesquisa científica e manutenção do parque. É uma zona que raramente se encontrará num parque urbano, haja vista as atividades antrópicas que geralmente já alteraram as suas condições ambientais originais. Porém, pode-se imaginar este tipo de zona num parque ecológico. Este tipo de parque urbano, conforme MACEDO e SAKATA (2002, p.13), tem por objetivo prioritário a conservação desse ou daquele recurso ambiental, como um banhado ou bosque. E, paralelamente, possui áreas muito concentradas, voltadas para o lazer ativo (jogos e recreação infantil), ao lado de áreas voltadas para o lazer passivo (caminhadas por trilhas bucólicas e esparsas). 
(II) Zona de uso extensivo: é aquela constituída na maior parte por áreas naturais, embora apresente alguma alteração humana. Destina-se ao lazer passivo: atividades contemplativas, leitura, passeios em trilhas esparsas, educação ambiental, etc.

(III)Zona recreativo-esportiva: área com ạlgumas alterações antrópicas. Destina-se à prática de atividades recreativas e esportivas para todas as idades. Pode conter quadras, campos e pistas esportivas, pista para caminhada e jogging, aparelhos para exercícios físicos, mesas de jogos, ciclovia, equipamentos para recreação infantil, restaurantes, lanchonetes, etc.

(IV)Zona histórico-cultural: destina-se ao lazer cultural. Pode conter museu, teatro, planetário, recinto de exposição, biblioteca, jardim de esculturas, jardim para deficientes visuais, jardim de leitura, etc. Contém também os edificios de valor cultural, monumentos, esculturas e sítios de interesse arqueológico histórico e pré-histórico. O Parque da Luz, por exemplo, possui os remanescentes (alicerces) de uma torre que serviu de observatório no século XIX, que se constitui num sítio arqueológico histórico. Possui ainda diversas edificações de valor cultural, como um coreto de ferro, um antigo quiosque, a casa do administrador, uma gruta e vários lagos artificiais, uma antiga cobertura de bondes puxados a muar, etc.

(V) Zona de recuperação: é aquela que contém áreas consideravelmente alteradas pelo homem, cujo aspecto natural se pretenda recuperar, como lagos poluídos, vegetação degradada, terrenos erodidos, etc. Ou onde se pretenda implantar algum equipamento. Zona provisória, que uma vez recuperada, será incorporada a uma das zonas permanentes.

(VI) Zona de administração: área onde a natureza está bastante alterada. É aquela que contém centro de visitantes, local de estacionamento, 
loja de lembranças, viveiro de plantas, hospital de animais silvestres, áreas administrativas e de serviços necessários à conservação do parque, etc.

O plano de manejo deve ser efetuado por equipe multidisciplinar de profissionais habilitados. Sua elaboração deve contar com a participação do conselho gestor, a quem caberá ao final a aprovação do plano de manejo. Durante o processo de elaboração, devem ser abertos canais para a participação e colaboração da comunidade de moradores da região, de representantes de entidades governamentais, não-governamentais e científicas, bem como é de se realizar ao menos uma audiência pública, aberta a todos os interessados, que terão direito ao uso da palavra.

Não basta a mera elaboração do plano de manejo, é preciso fazer o monitoramento constante, através do tempo para verificar a sua eficácia. De acordo com Mesquita (apud RIBEIRO, 2008, p.17), a avaliação do manejo não deve ser vista como um fim em si mesma, mas como um importante passo para determinar suas forças e fraquezas, com vistas ao monitoramento contínuo e aprimoramento da gestão.

RIBEIRO (2008, p.17) sugere alguns critérios para avaliação periódica da área preservada:

(I) Análise da fauna e flora encontradas no local.

(II) Análise da qualidade dos recursos hídricos.

(III) Avaliação dos usos da área, mediante pesquisa dos índices de satisfação dos usuários.

(IV)Avaliação das atividades culturais, educativas e científicas efetuadas no parque.

(V) Análise dos índices de satisfação dos residentes e moradores do entorno. 
(VI)Avaliação da pressão que os freqüentadores exercem sobre o parque e os equipamentos urbanos locais, com proposição de medidas para mitigação ou compensação de possíveis impactos negativos.

Cabe ressaltar que a Lei do SNUC (art. 27, caput) proíbe enfaticamente todas as alterações, atividades ou modalidades de utilização em desacordo com os objetivos da unidade e seu plano de manejo. Como se trata de norma geral, as leis estaduais e municipais que venham a tratar do parque urbano como unidade de conservação não poderão ser menos restritivas e portanto terão que confirmar essa proibição, sob pena de inconstitucionalidade.

Destarte, aprovado o plano de manejo, este deve ser cumprido à risca pela administração pública, pelos usuários, moradores do entorno e população em geral, ó que reforça sobremaneira a proteção do parque urbano.

\subsubsection{Zona de amortecimento e corredores ecológicos}

Como visto no item anterior, o plano de manejo deve abranger a área da unidade de conservação (parque urbano), sua zona de amortecimento e os corredores ecológicos (art. $27, \S 1^{\circ}$ da Lei do SNUC).

A zona de amortecimento constitui-se no entorno de uma unidade de conservação, onde as atividades humanas estão sujeitas a normas e restrições específicas, com o propósito de minimizar os impactos negativos sobre a unidade (inc. XVIII, art. $2^{\circ}$ da Lei do SNUC). Entorno é a área contígua ao parque urbano, no caso, prevista no plano de manejo (KRIEGER et al, 1998, p.155). Cabe ao órgão responsável pela administração da unidade estabelecer normas específicas regulamentando a ocupação e o uso dos recursos da zona de amortecimento (art. 25, $\S 1^{\circ}$ da lei do SNUC), que devem estar de acordo com as diretrizes traçadas pelo plano de manejo (art. $27, \S 1^{\circ}$ ). 
No caso em tela, os problemas de entorno têm caráter eminentemente urbano. Entre estes, que justificam a criação da zona de amortecimento estão: a verticalização excessiva, a construção de avenidas movimentadas, a implantação de indústrias poluidoras, as ligações de esgoto que deságuam nos lagos dos parques, a implantação de bairros carentes e loteamentos clandestinos, entre outros.

Muitas vezes um parque urbano torna-se um pólo atrativo para as incorporadoras construírem edificios altos nas suas proximidades. A vista perpétua, a presença da paisagem verde, o ar puro, a proximidade de uma bela área de lazer, todos esses elementos são fatores de valorização fartamente explorados nos anúncios de venda. No entanto, o excesso de edifícios de grande porte cria pólos de tráfego intenso de veículos, com poluição sonora e do ar que comprometem a sobrevivência da vegetação e da fauna, além de prejudicarem a saúde dos usuários, em especial daqueles que praticam exercícios físicos, em contradição direta com a publicidade dos empreendimentos imobiliários. Além disso, a verticalização do entorno pode prejudicar a ventilação e a insolação do parque urbano.

A implantação de vias de trânsito pesado em volta do parque, ou até debaixo dele, como ocorre no Ibirapuera, geram poluição do ar, sonora, põem em perigo os freqüentadores que se dirigem a pé ou de bicicleta para o parque. Não é à toa que o Parque do Ibirapuera tem um dos índices mais altos de poluição de ozônio da cidade. Assim, quem vai a um parque em busca de ar puro, na verdade pode estar sendo enganado, haja vista a quantidade de substâncias tóxicas que estará inspirando. E se fizer exercícios físicos, os riscos á saúde serão maiores ainda.

Em matéria de indústrias poluentes, basta recordar os estragos causados pela Metalúrgica Aliperti que se situava bem ao lado do Jardim Botânico de São Paulo. Ela por décadas poluiu horrivelmente o ar da região, cobriu de fuligem as folhas das plantas e provocou a degradação de boa parte da vegetação do jardim botânico, além de prejudicar a saúde dos moradores próximos. Graças às deficiências da legislação primitiva da época, sua sanha destruidora somente desapareceu devido a uma falência oportuna. 
Em cidades de saneamento precário com são as brasileíras, é muito comum a transformação de córregos e rios em condutores de esgoto, às vezes por ligações clandestinas, outras vezes, o que é mais grave, por iniciativa do próprio poder público. Assim, de pouco adiantam as redes coletoras de esgoto tecnicamente bem concebidas, ligadas a estações de tratamento se os dejetos continuam correndo a céu aberto e emporcalhando os pobres riachos que ainda insistem em seguir seu rumo natural, sujos, assoreados, sem vida e malcheirosos. Para solucionar o problema, segundo alguns administradores públicos, basta seguir a fórmula tão utilizada até hoje: canalização, tamponamento e construção de avenida por cima. E depois suportar as enchentes decorrentes desse processo de impermeabilização.

Entre esses córregos, existem aqueles formadores de lagos no interior de parques urbanos. Basta recordar os casos dos lagos dos Parques do Ibirapuera e da Aclimação que são muito poluídos e há décadas aguardam as promessas de despoluição não cumpridas pelos prefeitos das várias administrações que se sucedem.

E tais ligações despejando esgotos nos córregos são agravadas quando se implantam, junto ao parque urbano, bairros carentes, muitas vezes oriundos de loteamentos clandestinos. Os outros problemas e carências desses bairros de baixa renda acabam por também desaguar no parque urbano vizinho. Depredações, criminalidade, destruição de cercas, invasões, utilização de áreas do parque para consumo de drogas, despejos de lixo e entulho, desmanche de veículos roubados, abandono de animais domésticos, todos esses problemas podem ser vistos, em grau maior ou menor, nos parques urbanos situados nos bairros carentes de São Paulo. Até para local de crimes e desova de cadáveres podem servir esses parques urbanos da periferia da metrópole. Ainda estão vivos na memória das pessoas os crimes do chamado "maníaco do parque", que atraía as suas vítimas mulheres para lugares ermos do Parque Estadual das Nascentes do Ipiranga, mais conhecido como Parque do Estado, no bairro da Água Funda em São Paulo, onde eram por ele estupradas, mortas e enterradas. Até hoje na região há quem chame essa área verde de "Parque do Maníaco". 
Obviamente, não será o controle da zona de amortecimento suficiente para solucịonar todos esses problemas resultantes de malformações estruturais históricas da sociedade brasileira e da crônica falta de planejamento urbano que assola em geral nossas cidades. Mas o simples fato dos usos e limitações do entorno constarem do plano diretor, sob controle do conselho gestor do parque, dá respaldo jurídico para evitar ou tomar medidas para a correção de muitos dos problemas acima mencionados.

Basta lembrar do empreendimento imobiliário de grande porte que planejava se instalar na divisa do Parque da Aclimação e que foi impedido por decisão do Conselho Municipal de Preservação do Patrimônio Histórico, Cultural e Ambiental. Este fato ocorreu em razão do projeto descumprir as normas de entorno criadas pelo órgão colegiado, em razão do parque ser bem tombado. Ora, nem todos os parques são tombados, mas ações semelhantes seriam possíveis, se cada um deles tivesse uma zona de amortecimento devidamente regulamentada.

Corredores ecológicos, por sua vez, são definidos como porções de ecossistemas naturais ou seminaturais, ligando unidades de conservação, que possibilitam entre elas o fluxo de genes e o movimento da biota, facilitando a dispersão de espécies e a recolonização de áreas degradadas, bem como a manutenção de populações que demandam para sua sobrevivência áreas com extensão maior do que aquela das unidades individuais (art. $2^{\circ}$, inc. XIX da Lei do SNUC).

Por meio deles o SNUC busca reunir unidades de conservação de menor porte, que contêm ecossistemas relevantes, as quais se encontram isoladas, principalmente por fatores antrópicos, para evitar a perda de biodiversidade decorrente da falta de intercâmbio genético, criando melhores possibilidades de sobrevivência para a biota (RODRIGUES, 2005b, p.108).

Em áreas urbanas, a conectividade entre áreas naturais é dificultada pela malha viária, ocupação humana, dentre outros aspectos (RIBEIRO, 2008, p.15). Destarte, embora desejável, fica bastante difícil implantar corredores ecológicos 
entre parques urbanos. Mas não impossível, dependendo das condições ambientais de cada município. O papel de corredor ecológico, inclusive, pode ser exercido pelo parque linear, conforme FALCÓN (2007, p.47).

\subsubsection{Gestão compartilhada}

$\mathrm{Na}$ prática, a participação da iniciativa privada na gestão dos parques urbanos costuma ser muito tímida. Não passa daqueles programas "adote um parque", onde uma determinada empresa privada conserva a vegetação em troca de publicidade.

A Lei do SNUC abre uma perspectiva mais ampla de gestão compartilhada. Ela autoriza que as unidades de conservação sejam geridas por organizações da sociedade civil de interesse público com objetivos afins às da unidade, mediante instrumento a ser firmado com o órgão responsável por sua gestão (art. 30).

Observe-se que não é qualquer tipo de organização não governamental que pode gerir uma unidade de conservação, mas tão somente aquele tipo de entidade qualificada como "organização da sociedade civil de interesse público" (OSCIP). Inclusive o instrumento a ser firmado entre as partes é o denominado "termo de parceria", referido nos arts. $9^{\circ}$ a 15 da Lei 9.790 de 23/03/1999.

Para tal gestão a OSCIP deve ter entre seus objetivos institucionais a proteção do meio ambiente ou a promoção do desenvolvimento sustentável e comprovar a realização de um desses tipos de atividade preferencialmente em unidades de conservação ou no mesmo bioma (incs. I e II do art. 22 do Dec. 4.340 de $22 / 08 / 2002$ ). 
A seleção de organizações sociais para efetuar gestão compartilhada deve ser precedida pela publicação de edital em jornal de grande circulação na região da unidade e no Diário Oficial, com no mínimo sessenta dias de antecedência, obedecidos os termos da Lei 8.666 de 21/06/1993 (Lei de Licitações e Contratos), de acordo com o art. 23 do Dec. 4.340/2002.

O termo de referência para apresentação de proposta pela OSCIP deve ser definido pelo órgão executor, ouvido o conselho da unidade de conservação (conselho gestor, no caso de parque urbano), conforme o citado art. 23 do Dec. 4.340/2002. A OSCIP que tenha representação no conselho da unidade de conservação não pode se candidatar a gestora partilhada (art. $17, \S 4^{\circ}$, do mesmo decreto).

Além dissó, cumpre à OSCIP encaminhar relatórios anuais de suas atividades a serem apreciadas pelo órgão executor e pelo conselho da unidade de conservação (art. 24 do referido decreto).

MERCADANTE (2001, p.557) posiciona-se no sentido de que as unidades de conservação podem ser geridas exclusivamente por organizações não governamentais, que seriam mais eficazes que o poder público na mediação e conciliação de conflitos de interesses, no estímulo à participação da população, como também na captação de recursos financeiros.

A gestão compartilhada pode vir a ser uma alternativa que garanta o processo de continuidade na administração de parques urbanos, na medida em que evite que estes alternem momentos de apogeu e decadência, ao gosto do administrador público do momento, como costuma acontecer historicamente. Esta continuidade seria bastante favorecida pela maior possibilidade de captação de recursos pela OSCIP, o que garantiria uma maior sustentabilidade econômica e reduziria a dependência de recursos orçamentários que tanto dificulta a boa gestão dos parques urbanos. 


\section{CONCLUSÕES}

Embora o rol do Sistema Nacional de Unidades de Conservação (SNUC) seja aparentemente exaustivo, na verdade não esgota as categorias existentes. É possivel observar-se outras categorias de unidades de conservação federais, inclusive de origem internacional, em diplomas legais esparsos. A própria Lei 9.985 de 18/07/2000 contém a reserva da biosfera (art. 41) que não se inclui nem no grupo de proteção integral, nem no de uso sustentável. Ou seja, está na Lei do SNUC, mas dele não faz parte.

Estados, Municípios e Distrito Federal têm competência constitucional para criar, mediante leis próprias, categorias de unidades de conservação em sentido amplo, distintas daquelas do SNUC, que podem ser sistematizadas ou não. Basta apenas que tais categorias possam ser enquadradas no conceito de unidade de conservação contido no art. $2^{\circ}$, inc. I da Lei do SNUC. Os Estados, Municípios e Distrito Federal podem pleitear, caso desejem, o reconhecimento dessas categorias próprias junto ao CONAMA, com fulcro no art. $6^{\circ}, \S$ único da Lei do SNUC. Porém, mesmo que assim não façam, não estarão praticando nenhum ato ilegal ou inconstitucional.

Inclusive, tais categorias próprias podem ser voltadas para o meio urbano, até porque os Estados, Municípios e Distrito Federal estarão exercendo sua competência constitucional supletiva, eis que o SNUC tratou apenas da preservação no âmbito rural (art. 24, $\S \S 2^{\circ}$ e $3^{\circ}$; art. 30, incs. I e II, da Constituição Federal). E os Estados, Municípios e Distrito Federal, apesar de certa timidez, vêm exercendo esta competência.

Existe uma grande divergência jurídica em torno dos conceitos de "urbano" e "rural". Não existe, porém, nenhum impedimento legal de se criar unidades de conservação integral em área urbana. Quando a Lei do SNUC informa que a área desse grupo de unidades deve ser considerada rural, não subordina a sua 
criação ao talante das leis municipais, mas tão somente proíbe a urbanização, ou seja, a edificabilidade e a vialidade da área, mesmo pelo Município. Podem ser citadas as reservas particulares do patrimônio natural municipais de Curitiba, como exemplo de unidades de conservação de proteção integral no meio urbano.

Existem precedentes legais considerando parques urbanos como unidades de conservação, observáveis em normas das esferas estadual e municipal. Assim, o Sistema Estadual de Unidades de Conservação da Bahia, criado pela Lei 10.431 de 10/12/2006, reconhece o parque urbano como unidade de conservação de uso sustentável. O Sistema Municipal de Unidades de Conservação de Curitiba, criado pela Lei 9.804 de 03/01/2000, considera o parque urbano como unidade de conservação, sem classificação específica, com a denominação de parques e bosques de lazer, que diferem um do outro apenas por questão de dimensões. Já o Sistema Municipal de Unidades de Conservação de Goiânia, ainda em projeto, cria um grupo específico de áreas verdes, tratadas juridicamente como unidades de conservação, com a denominação de parques urbanos.

A preservação do verde no meio urbano é essencial para a qualidade de vida das cidades. A vegetação resulta em benefícios à saúde, físicos, químicos, biológicos, sociais, psicológicos e econômicos para as populações residentes nas cidades. Esses benefícios, no Brasil, são especialmente reconhecidos pelo Estatuto da Cidade. E devem ser referidos em seu principal instrumento jurídico, o plano diretor de cada Município. O parque urbano exerce relevantes funções nesse contexto.

Não existe consenso científico quanto ao conceito de cidade, nem tampouco com relação ao de parque urbano. Mas, com amparo nos diversos conceitos internacionalmente aplicados e na legislação brasileira, é possível definir o parque urbano como uma modalidade de unidade de conservação, com o objetivo básico de preservar a natureza em harmonia com atividades de lazer, educativas e culturais no meio urbano.

O mais importante não é conferir ao parque urbano o mero rótulo formal de unidade de conservação. O fundamental é a aplicação ao parque urbano do regime 
jurídico próprio das unidades de conservação, no que couber, com a finalidade de garantir a sua proteção e o exercício adequado de suas funções sócio-ambientais no meio artificial ou urbano.

Assim, são institutos jurídicos característicos das unidades de conservação aplicáveis aos parques urbanos: o conselho gestor, o plano de manejo, a zona de amortecimento, os corredores ecológicos (mais raramente), a gestão compartilhada com organização da sociedade civil de interesse público (OSCIP).

Com a utilização eficaz desses instrumentos, que abrem espaços para o controle social e participação ativa da sociedade em defesa dos parques urbanos, entendemos que poderão ser evitados ou sensivelmente reduzidos problemas graves, do tipo daqueles historicamente sofridos pelos Parques da Luz, Tenente Siqueira' Campos, da Aclimação e do Ibirapuera, que foram acima estudados em maiores detalhes. São eles: a perda de áreas para uso particular e institucional; descaracterização de usos e desenho; períodos de decadência e apogeu alternados, na dependência da boa vontade do prefeito do momento; poluição do ar e da água (lagos); depredação por usos inadequados; ausência crônica de recursos financeiros; falta de controle do entorno, entre outros. 


\section{REFERÊNCIAS}

ACRE. Lei 1.426, de 27 de dezembro de 2001. Dispõe sobre a conservação das florestas do estado, institui o sistema estadual de áreas naturais protegidas, cria o conselho florestal estadual e o fundo estadual de florestas. Diário Oficial do Estado do Acre, Rio Branco, Acre, 03 jan. 2002, p.1-3.

AGUIAR, J. C. Direito da cidade. Rio de Janeiro: Renovar, 1996.

AGUIAR, R. R. de. O meio ambiente e a jurisprudência do Superior Tribunal de Justiça. Revista de Direito Ambiental. v.25, p.193-206, 2002.

ALAGOAS. Decreto 35.732 , de $1^{\circ}$ de abril de 1993. Institui a Reserva estadual de preservação ecológica. Disponível em: <http://www.ima.al.gov.br/legislacao/decretos-estaduais>. Acesso em: 15 mai. 2008.

ALAGOAS. Decreto 32.510, de 6 de julho de 1987. Dispõe sobre a implantação de Cinturão verde de proteção ambiental na restinga do Pontal da Barra. Disponível em:

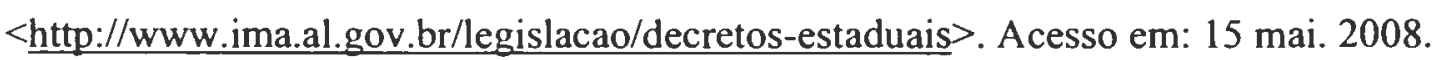

ALBUQUERQUE, M. Z. A. Espaços livres públicos inseridos na paisagem urbana: memórias, rugosidades e metamorfoses: estudo dos parques urbanos 13 de maio, Recife-Brasil e do Tiergarten, Berlim-Alemanha. 2006. 233p. Dissertação (Mestrado em Geografia) - Centro de Filosofia e Ciências Humanas, Universidade Federal de Pernambuco, Recife.

AMAPÁ. Lei Complementar 05, de 18 de agosto de 1994. Cria o código de proteção ao meio ambiente. Disponivel em: <http://www.al.ap.gpv.br/lei_comp005a.htm $>$. Acesso em: 10 mai. 2008. 
AMAZONAS. Lei Complementar 53, de 05 de junho de 2007. Regulamenta o inciso $\mathrm{V}$ e o $\S 1^{\circ}$ do artigo 231 da constituição estadual e instituí o sistema estadual de unidades de conservação - SEUC. Disponivel em:

http://www.sds.am.gov.br/dsu/download/imgdownload/20070808160635LEI\%20SE UC.pdf < Acesso em: 10 mai. 2008.

ANDRADE, M. M. O parque do Ibirapuera: 1890 a 1954. Disponível em: <http://www.vitruvius.com.br/arquitextos/arq051/aer051 01.asp $>$. Acesso em: 04 jul. 2008.

ANTUNES, P. de B. Direito ambiental. Rio de Janeiro: Lúmen Júris, 2007.

AUGUSTO, H. Parque Ibirapuera pode ganhar outras áreas, 23 ago. 2007. Disponivel em: $<$ http://wwwl.folha.uol.com.br/folha/dimenstein/notiias/gd230807.htm $>$.

Acesso em: 23 jun. 2008.

BAEYER, $\mathrm{E}$ von. Parcs urbains. Disponivel em: $<\underline{\text { http://www.thecanadianencyclopedia.com/index.cfm?PgNm=TCE\&Params=flART }}$ f00060.htm>. Acesso em: 13 jul. 2008.

BALZA, S. F. L. Conceptos sobre espacio público, gestión de proyectos y lógica social: reflexiones sobre la experiencia chilena. EURE (Santiago), vol.24, $\mathrm{n}^{\circ} 71$, p.27-36, 1998.

BARIDON, M. La revolution industrielle et les grands parcs urbains en France, en Angleterre et aux Etats-Unis. Disponivel em: $<$ http://patrimoine.saline.free.fr/baridon.htm $>$. Acesso em: 13 jul. 2008.

BARROS, M. Ibirapuera ganha biblioteca que abre só em dia de semana. Folha de S. Paulo, São Paulo, p.C4, 10 mai. 2008. 
BARROSO, L. R. Serviço de transporte ferroviário e federação: instituição de padrões ambientais de segurança. In: DAIBERT, A. (Org.). Direito ambiental comparado. Belo Horizonte: Fórum, 2008, p.103-146.

BARTALINI, V. Parques públicos municipais de São Paulo: a ação da municipalidade no provimento de áreas verdes de recreação. 1999. 354p. Tese (Doutorado em Arquitetura) - Faculdade de Arquitetura e Urbanismo, Universidade de São Paulo, São Paulo.

BENJAMIN, A. H. de V. e. O regime brasileiro das unidades de conservação. Revista de Direito Ambiental, v.21, p.27-56, 2001.

BENSUSAN, N. Conservação da biodiversidade em áreas protegidas. Rio de Janeiro: FGV, 2006.

BERJMAN, S. O espaço verde público: modelos materializados em Buenos Aires parte 1. Disponível em:.

$<$ http://www.vitruvius.com.br/arquitextos/arq000/esp046.asp >. Acesso em: 14 jul. 2008.

BILLAUDOT, F; BESSON-GUILLAUMOT, M. Environnement, urbanisme, cadre de vie: le droit et l'administration. Paris: Montchrestien, 1979.

BITTAR, E. C. B. Metodologia da pesquisa jurídica: teoria e prática da monografia para os cursos de direito. São Paulo: Saraiva, 2007.

BLACKMAR, E; ROSENZWEIG R. Central Park history. Disponível em:

<http://www.centralpark.com/pages/history_4.html>. Acesso em: 13 jul. 2008.

BONDUKI, N. Origens da habitação social no Brasil: arquitetura moderna, lei do inquilinato e difusão da casa própria. São Paulo: Estação Liberdade; FAPESP, 1998. 
BORJA, J. La ciudad y la nueva cidadania, 02 mai. 2002. Dispenível em:

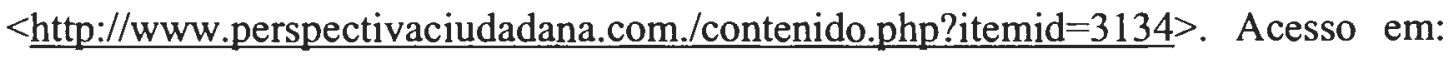
24 ago. 2008.

BRANCO, S. M. Ecossistêmica: uma abordagem integrada do s problemas do meio ambiente. São Paulo: Edgard Blücher, 1999.

BRANCO, S. M. Meio ambiente: uma questão moral. São Paulo: OAK, 2002.

BRASIL. Coletânea de legislação ambiental, Constituição Federal. MEDAUAR, O. (Org.). São Paulo: Revista dos Tribunais, 2008.

BRESCIANI, M. S. Cidade e história. In OLIVEIRA, L. L. (Org.). Cidade: história e desafios. Rio de Janeiro: FGV, 2002, p.16-35.

BRUNO, E. S. História e tradições da cidade de São Paulo. Rio de Janeiro: José Olympio, 1954. 3v.

BRUNO, E. S. Memória da cidade de São Paulo: depoimento de moradores e visitantes (1553-1958). São Paulo: Prefeitura Municipal; Secretaria Municipal de Cultura; Departamento do Patrimônio Histórico, 1981.

BUCCHERI FILHO, A. T.; NUCCI, J. C. Espaços livres, áreas verdes e cobertura vegetal no bairro Alto da XV, Curitiba-PR. Revista do Departamento de Geografia (USP), $\mathrm{n}^{\circ} 18, \mathrm{p} .48-59,2006$.

CAESB - Companhia de Saneamento Ambiental do Distrito Federal. Disponivel em: <http://www.caesb.df.gov.br/_conteudo/Legislacao/Decretos/Decreto18585.asp $>$. Acesso em: 15 mai. 2008.

CAFÉ já é ilegal no parque Ibirapuera. O Estado de S. Paulo, São Paulo, 23 jul. 1975. 
CAMARGO, L. O. L. O que é lazer. São Paulo: Brasiliense, 2003.

CAMPILONGO, C. F. O caso Finasa Seguradora (2001): ato de concentração ${ }^{\circ}$ 08012.006762/2000-09, requerentes: Banco Finasa de Investimentos S/A, Brasmetal Indústria S/A e Zurich Participações e Representações, conselheira -relatora :Hebe Teixeira Romano, voto de vista. In: CAMPILONGO, C. F. et al. (Coords.). Concorrência e regulação do sistema financeiro. São Paulo: Max Limonad, 2002, p.471-496.

CAMPOS, C. M. Os rumos da cidade: urbanismo e modernização em São Paulo. São Paulo: SENAC, 2002.

CANEPA, C. Cidades sustentáveis: o município como locus da sustentabilidade. São Paulo: RCS, 2007.

CASTELLS, M. A questão urbana. São Paulo: Paz e Terra, 2006.

CASTELNOU, A. M. N. Parques urbanos de Curitiba: de espaços de lazer a objetos de consumo. Cadernos de Arquitetura e Urbanismo, v.13, n.14, 2006, p.53-74.

CASTRO, M. L. de. O Parque da Aclimação será preservado. Jornal do Cambuci/Jornal da Aclimação, São Paulo, p.6-7, 9-23 mai. 1986.

CAVALCANTI, L. de S. Uma geografia da cidade: elementos da produção do espaço urbano. In: CAVALCANTI, L de S. (Org.). Geografia da cidade. Goiânia: Alternativa, 2001, p.11-32.

CEARÁ. Superintendência do meio ambiente. Disponivel em: $<\underline{\text { http://www.semace.ce.gov.br/> }}$. Acesso em: 15 mai. 2008.

CESUR: área científica de urbanismo, dinâmicas espaciais e ambiente. Proposta de plano de pormenor da zona de expansão norte de Sines. Disponível em: $<$ http://www.sines.pt/PT/VIVER?Urbanismo/pps/ppzonanorte/Documents/PP\%202E 
$\% 20$ NORTE $\% 20$ de $\% 2020$ Sines $\% 20-\% 20$ Proposta $\% 20$ de $\% 20$ relatorio.pdf $>$. Acesso em: 17 jul. 2008.

CETESB. Floresta será o maior atrativo do Parque Tizo, 09 jun. 2006. Disponível em: $<$ http://www.cetesb.sp.gov.br/noticentro/2006/06/09 projeto.htm $>$.

Acesso em: 31 ago. 2008.

CHAUÍ, M. Convite à filosofia. São Paulo: Ática, 2003.

COMPANHIA DO DESENVOLVIMENTO DOS VALES DO SÃO FRANCISCO E DO PARNAÍBA. Disponível em: $<$ http://www.codevasf.gov.br/programas_acoes/programa-florestal-1/acoesflorestais-na-bacia-do-parnaiba/unidade-de-conservacao-do-piaui>. Acesso em: 15 mai. 2008.

CONCEIÇAO, M. D. N. Conceitos indeterminados na constituição: requisitos da relevância e urgência (artigo 62 da CF). São Paulo: Celso Bastos, 1999.

CONPRESP. Legislação. Lei 14.719, de 25 de abril de 2008. Declara de utilidade pública área particular destinada à implementação do Parque da Aclimação. Disponível em: $<$ http://www.prefeitura.sp.gov.br/cidade/secretarias/cultura/cinpresp/legislacao/leis/i ndex.php?p=1133>. Acesso em: 21 mai. 2008.

CORONA, M. A. Los parques urbanos y su panorama em la zona metropolitana de Guadalajara. Revista de Vinculación y Ciencia, $\mathrm{n}^{\circ}$ 09, p.4-16, Universidad de Guadalajara, 2002.

CRESPO, R. A. Cultura e ideologia. In: TOMAZI, N. D. (Coord.). Iniciação à sociologia. São Paulo: Atual, 2000, p.173-220. 
CRUZ, A. P. F. N. da. A tutela ambiental do ar atmosférico. Rio de Janeiro: Esplanada, 2002.

CRUZ, E. P.; RODRIGUES, P. Em 2008, metade da população mundial estará vivendo em áreas urbanas, diz relatório da ONU, 27 jun. 2007. Disponível em: $<$ http://www.agenciabrasil.gov.br/noticias/2007/06/27/materia.2007-06-

27.3709223479/view>. Acesso em 24 ago. 2008.

CURITIBA. Lei 9.804 de 03 de janeiro de 2000. Cria o sistema de unidades de conservação do municipio de Curitiba e estabelece critérios e procedimentos para implantação de novas unidades de conservação. Disponível em: $<$ http://www.curitiba.pr.gov.br/pmc/servicos/legislacao/zoneamento/index.html $>$. Acesso em: 22 jul. 2008.

CURY, I (Organizadora). Cartas patrimoniais. Rio de Janeiro: IPHAN, 2000.

CUSTÓDIO, H. B. Direito ambiental e questões juridicas relevantes. Campinas: Millennium, 2005.

CUSTÓDIO, H. B. Responsabilidade civil por danos ao meio ambiente. Campinas: Millennium, 2006.

CYPRIANO, F. SP planeja museu de folclore. Folha de S. Paulo, São Paulo, p.E3, 14 jun. 2008.

DAEE. Parque ecológico do Tietê: centro de lazer eng. Goulart. Disponível em: $<$ http://www.daee.sp.gov.br/cgi-bin/carrega.exe?arg=/parques/clgoulart02.htm>. Acesso em: 31 ago. 2008.

DERANI, C. A estrutura do sistema nacional de unidades de conservação. Revista de Direitos Difusos, v.5, p.607-616, 2001.

DERANI; C. Direito ambiental econômico. São Paulo: Saraiva, 2008. 
DINIZ, F. de A. (Junius). Notas de viagem. São Paulo: Governo do Estado, 1978.

DOREA, A. G. R. Aclimação. São Paulo: Departamento do Patrimônio Histórico, 1982.

DREW, D. Processos interativos homem-meio ambiente. Rio de Janeiro: Bertrand Brasil, 1998.

DUARTE, A. C. P. B. Avaliação pós ocupação do parque urbano dos Moinhos de Sant'Ana em Lisboa., maio de 2002. Disponível em: $<$ http://www.eventos.uevora.pt/cpea/CristinaDuarte.pdf $>$. Acesso em: 18 set. 2008.

ETZEL, E. O verde na cidade de São Paulo. Revista do Arquivo Municipal, nº 195, p.51-76, 1982.

FALCÓN, A. Espacios verdes para una ciudad sustenible: planificación, proyecto, mantenimiento y gestión. Barcelona: Gustavo Gili, 2007.

FARIAS, P. J. L. Competência federativa e proteção ambiental. Porto Alegre: Sérgio Antonio Fabris, 1999.

FERREIRA, A. B. de H. Dicionário Aurélio básico da língua portuguesa. Rio de Janeiro: Nova Fronteira, 1988.

FIGUEIREDO, G. J. P. de. Curso de direito ambiental. Curitiba: Arte e Letra, 2008a.

FIGUEIREDO, G. J. P. de. A propriedade no direito ambiental. São Paulo: Revista dos Tribunais, 2008b.

FOLHA ON LINE. Áreas municipais cedidas a terceiros, 16 set. 2002. Disponível em: <http://wwwl.folha.uol.com.br/folha/cotidiano/lt95u59016.shtml $>$. Acesso em: 29 jun. 2008. 
FRANCO, M. de A. R. Desenho ambiental: uma introdução à arquitetura da paisagem com o paradigma ecológico. São Paulo: Annablume, 2000.

FREITAG, B. Cidade dos homens. Rio de Janeiro: Tempo Brasileiro, 2002.

FREITAS, J. C. de. Proteção jurídica do meio ambiente urbano. In: MARQUES, J. R. (Org). Leituras complementares de direito ambiental. Salvador: Podium, 2008, p.197-213.

FREITAS, W. P. de. A Constituição Federal e a efetividade das normas ambientais. São Paulo: Revista dos Tribunais, 2000.

FRIEDEL, H. As grandes leis da biosfera. In: CHARBONNEAU, J-P et al. Enciclopédia de ecologia. São Paulo: EPU; EDUSP, 1979, p.09-41.

FUNDAÇÃO PARQUE ZOOLÒGICO DE SÃO PAULO. História do zôo. Disponivel em: <http://www.zoologico.sp.gov.br/historiadozoo.htm $>$. Acesso em: 13 ago. 2008 .

FURLAN, S. A. Paisagens sustentáveis: São Paulo e sua cobertura vegetal. In: CARLOS, A. F. A. e OLIVEIRA A. U (Orgs.). Geografias de São Paulo: a metrópole do século XXI. São Paulo: Contexto, 2004, p.255-283.

GALVÃO, V. Q. Avenida Paulista ganhará parque com cara de praça. Folha de S. Paulo, São Paulo, p.C8, 25 abr. 2008.

GERALDO, J. C. A evolução dos espaços livres públicos de Barueri, Brotas e Dois Córregos-SP. 1997. 207p. Dissertação (Mestrado em Geografia Física) - Faculdade de Filosofia, Letras e Ciências Humanas. Universidade de São Paulo, São Paulo.

GIOIA, M. Museus no parque. Folha de S. Paulo, São Paulo, p.E1e E3, 02 jun. 2008.

GIST, N. P.; FAVA, S. F. La sociedad urbana. Barcelona: Omega, 1968. 
GOIÂNIA. Minuta de projeto de lei que institui o sistema municipal de unidades de conservação da natureza, parques urbanos e áreas verdes de complemento urbano. Disponível em: <http://www.goiania-go.gov.br/download/semma/smuyc.doc $>$. Acesso em: 31 mai. 2008.

GOIÁS. Lei 14.247 de 29 de julho de 2002. Institui o sistema estadual de unidades

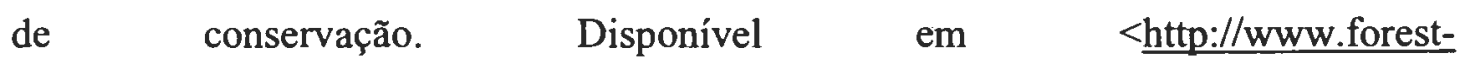
trends.org/biodiversityoffsetprogramBBop $\% 201$ ibrary $\% 202 /$ Brazil $\% 20$ \%20All\%20Not\%20Printed/Goias\%20LEI\%2014.247-02.doc >. Acesso em: 11 mai. 2008 .

GOITIA, F. C. Breve história do urbanismo. Lisboa: Presença,1996.

GOVERNO DO ESTADO DE SÃO PAULO. Parque Villa Lobos. Disponível em: $<$ http://www.saopaulo.sp.gov.br/saopaulo/turismo/cap parq villa.htm $>$. Acesso em 21 ago. 2008.

GUARALDO, E. Repertório e identidade: espaços públicos em São Paulo, 18901930. 2002. 153 p. Tese (Doutorado em Arquitetura) - Faculdade de Arquitetura e Urbanismo, Universidade de São Paulo, São Paulo.

HIERNAUX, D. Repensar a cidade: a dimensão ontológica do urbano. GEOUSP Espaço e Tempo, n 20, p.197-205, 2006.

HOMEM, M. C. N. Higienópolis: grandeza e decadência de um bairro paulistano. São Paulo: Secretaria Municipal de Cultura, 1980.

HOUGH, M. Naturaleza y ciudad: planificación urbana y procesos ecológicos. Barcelona: Gustavo Gili, 2004.

INSTITUTO BIOLÓGICO. Quem somos. Disponível em:

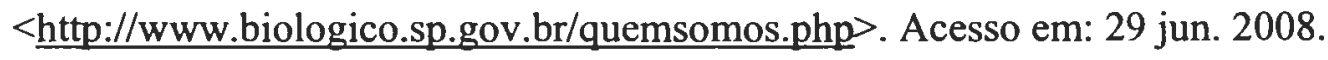


INSTITUTO DANTE PAZZANESE DE CARDIOLOGIA. Histórico. Disponível em: $<$ http://www.dantepazzanese.org.br/siteDante/hist idpc.htm>. Acesso em: 23 jun. 2008.

ISIDORO A.; CREDENCIO J. E. Área cobiçada pelo Ibirapuera vira estacionamento ilegal. Folha de S. Paulo, São Paulo, p.C7, 23 fev. 2008.

JACOBS, J. Morte e vida de grandes cidades. São Paulo: Martins Fontes, 2001.

JARDIN D'ACCLIMATATION. Disponível em:

$<$ http://www.jardindacclimatation.fr $>$. Acesso em: 8 mai. 2008.

JORGE, C. de A. Luz: notícias e reflexões. São Paulo: Departamento do Patrimônio Histórico, 1988.

KIDDER, D. P. Reminiscências de viagens e permanência no Brasil (Rio de Janeiro e província de São Paulo). São Paulo: Martins; Edusp, 1972.

KLIASS, R. G. Parques urbanos de São Paulo. São Paulo: Pini, 1993.

KLOETZEL, K. O que é meio ambiente. São Paulo: Brasiliense, 2002.

KOSERITZ, C. v. Imagens do Brasil. São Paulo: Martins; Edusp, 1972.

KRIEGER, M. da G.; MACIEL, A. M. B.; ROCHA, J. C. de C.; FINATTO, M. J. B.; BEVILACQUA, C. R. (Orgs.). Dicionário de direito ambiental: terminologia das leis do meio ambiente. Porto Alegre; Brasília: Universidade do Rio Grande do Sul; Ministério Público Federal.

KÜHL, B. M. Arquitetura de ferro e arquitetura ferroviária em São Paulo: reflexões sobre a sua preservação. São Paulo: Ateliê; Fapesp; Secretaria da Cultura, 1998. 
LANGLEY, S. The system of protected areas in the United States. In: BENJAMIN, A. H. (Coord.). Direito ambiental das áreas protegidas: o regime jurídico das unidades de conservação. Rio de Janeiro: Forense Universitária, 2001, p.116-163.

LE CORBUSIER. Urbanismo. São Paulo: Martins Fonte, 2000.

LEFEBVRE, H. O direito à cidade. São Paulo: Centauro, 2006

LEFĖVRE, J. E. de A. Marquise do Ibirapuera: onde está o equívoco? Desígnio: revista de história da arquitetura e urbanismo, $\mathrm{n}^{\circ} 04,2005, \mathrm{p} .165-171$.

LEITE, J. R. M. Dano ambiental: do individual ao coletivo extrapatrimonial. São Paulo: Revista dos Tribunais, 2000.

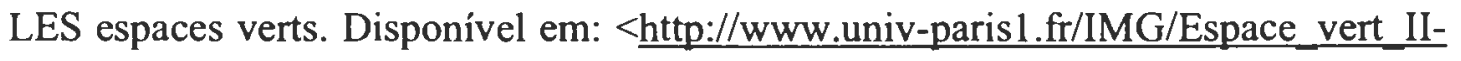
2.doc>. Acesso em: 07 ago. 2008.

LEUZINGER, M. D. Meio ambiente: propriedade e repartição constitucional de competências. Rio de Janeiro: Esplanada, 2002.

LIMA, A. M. L. P.; CAVAlhEIRO, F; NUCCI, J. C.; SOUSA, M. A. de L. B.; FIALHO, N. de O; DEL PICCHIA, P. C. D. Problemas de utilização na conceituação de termos como espaços livres, áreas verdes e correlatos. In: CONGRESSO BRASILEIRO DE ARBORIZAÇÃO URBANA, 2., 1994, São Luís. Anais... São Luís: Imprensa EMATER/MA, 1994, p.539-553.

LIMA, J. O de. Conceitos e diferenças entre recreação, lazer, jogo e brincadeira, 2007. Disponivel em: $<$ http://www.artigocientifico.com.br/uploads/artc 1206841970 97.doc $>$. Acesso em: $1^{\circ}$ set. 2008 .

LOBODA, C. L.; DE ANGELIS, B. L. D. Áreas verdes públicas urbanas: conceitos, usos e funções. Ambiência, v.01, p.125-139, 2005. 
LOFEGO, S. L. IV centenário da cidade de São Paulo: uma cidade entre o passado e o futuro. São Paulo: Annablume, 2004.

LOUREIRO, C. F. B. Gestão ambiental participativa em unidades de conservação. In: - Cidadania e meio ambiente. Salvador: Centro de Recursos Ambientais, 2003, p.111-122.

LOUREIRO, W. ICMS ecológico: a consolidação de uma experiência brasileira de incentivo à conservação da biodiversidade. Disponivel em:

<http://www.ambientebrasil.com.br/composer.php3?base=./snuc/index.html\&conteu do=./snuc/artigos/icms.html > . Acesso em: 28 mai. 2008.

MACEDO, S. S.; SAKATA, F. G. Parques urbanos no Brasil. São Paulo: Edusp; Imprensa Oficial, 2002.

MACHADO, P. A. L. Estudos de direito ambiental. São Paulo: Malheiros, 1994.

MACHADO, P. A. L. Direito ambiental brasileiro. São Paulo: Malheiros, 2005.

MACHADO, P. A. L. Direito à informação e meio ambiente. São Paulo: Malheiros, 2006.

MAGALHÃES, M. R. A arquitetura paisagística: morfologia e complexidade. Lisboa: Estampa, 2001.

MAIA, P. Os melhoramentos de São Paulo. São Paulo: Prefeitura Municipal de São Paulo, 1945.

MAM. Sobre o MAM: história. Disponível em: $<$ http://www.mam.org.br $>$. Acesso em: 28 mai. 2008. 
MANAUS. Lei 605, de 24 de julho de 2001. Institui o código ambiental do município de Manaus. Disponivel em: $<$ http://www.manaus.am.gov.br/servicos/biblioteca/lei605_codigo_ambiental.pdf $>$. Acesso em: 31 mai. 2008.

MANCUSO, R. de C. Ação civil pública em defesa do meio ambiente, do patrimônio cultural e dos consumidores: Lei $7.347 / 87$ e legislação complementar. São Paulo: Revista dos Tribunais, 2002.

MARANHÃO. Medida Provisória 12, de 14 de setembro de 2006. Dispõe sobre a política florestal e de proteção à biodiversidade. Disponível em:

$<$ http://www.age.ma.gov.br/index.php?catID=50\&ID=616>. Acesso em: 11 mai. 2008.

MARCONDES, M. J. de A. Cidade e natureza: proteção dos mananciais e exclusão social. São Paulo: Studio Nobel; Edusp, 1999.

MARIANO, C. R. Parques metropolitanos de São Paulo: subsídios para o desenho. 1992. 218p. Dissertação (Mestrado em Estruturas Ambientais Urbanas) - Faculdade de Arquitetura e Urbanismo, Universidade de São Paulo, São Paulo.

MARQUES, J. R. Meio ambiente urbano. Rio de Janeiro: Forense Universitária, 2005 .

MARQUES, M. E. de A. Apontamentos históricos, geográficos, biográficos, estatísticos e noticiosos da Província de São Paulo. Belo Horizonte: Itatiaia; São Paulo: Edusp, 1980. 2v.

MARQUES, M. I. M. O conceito do espaço rural em questão. Tema Livre. São Paulo: ano 18, n 19, p.95-112, 2002. 
MARTINS, A. E. São Paulo antigo (1554-1910). São Paulo: Conselho Estadual de Cultura, 1973.

MARTINS, C. MAC terá $30 \mathrm{mil} \mathrm{m} 2$ de área para expor seu acervo de 10 mil obras. Diário Oficial do Estado, São Paulo, Poder Executivo, seção II, p.I, 16 abr. 2008.

MASAROLO, P. D. O bairro da Vila Mariana. São Paulo: Secretaria de educação e Cultura, 1971.

MATO GROSSO. Decreto 1.795, de 04 de novembro de 1997. Regulamenta o sistema estadual de unidades de conservação. Diário Oficial do Estado do Mato Grosso, Cuiabá, Mato Grosso, 04 nov. 1997, p.1-3.

MATO GROSSO. Decreto 5.436, de 12 de novembro de 2002. Disponível em: $<\underline{\text { http://www.repams.org.br/legislacao.php? } \operatorname{cod}=20}>$. Acesso em: $11 \mathrm{mai} 2008$.

MATTOS NETO, A. J. de. Competência legislativa municipal sobre meio ambiente. Revista de Direito Ambiental, v.14, p.120-139, 1999.

MAYUMI, L; SANCHES, M. Histórico da obra de restauro e conservação da casa do administrador: Parque da Luz. In: GLUECK, S. C. A casa do administrador: parque jardim da Luz. São Paulo: Secretaria Municipal do Verde e do Meio Ambiente, 2008.

MAZZILLI, H. N. A defesa dos interesses difusos em juízo. São Paulo: Saraiva, 1997.

MEDAUAR, O. Comentários aos artigos $1^{\circ}$ a $3^{\circ}$. In: MEDAUAR , O.; ALMEIDA, F. D. M. de. (Coord.). Estatuto da cidade: Lei 10.257, de 10.07.2001: comentários. São Paulo: Revista dos Tribunais, 2002, p.11-27.

MEIRELLES, H. L. Direito municipal brasileiro. São Paulo: Malheiros, 1993. 
MELLO, C. C. do A. Agenda 21 local: um glossário analítico para o debate. In: ACSELRAD, H.; MELLO, C. C. do A. BEZERRA, G. das N. (Orgs). Cidade, ambiente e política: problematizando a Agenda 21 local. Rio de Janeiro: Garamond, 2006, p.33-87.

MERCADANTE, M. Democratizando a criação e a gestão de unidades de conservação da natureza: a Lei 9.985, de 18 de julho de 2000. Revista de direitos difusos, v.5, p.557-586, 2001.

MILARÉ, E. Sistema municipal do meio ambiente, Sismuma: instrumentos legais e econômicos. Revista de Direito Ambiental, v.14, p.38-47, 1999.

MILARÉ, E. Direito do ambiente: a gestão ambiental em foco: doutrina, jurisprudência, glossário. São Paulo: Revista dos Tribunais, 2007.

MINAS GERAIS. Lei 14.309 , de 19 de junho de 2002. Dispõe sobre a política florestal e de proteção à biodiversidade. Disponível em:

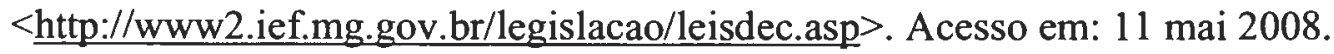

MIRANDA, M. P. de S. Áreas de proteção especial: valiosos e pouco conhecidos instrumentos de defesa do meio ambiente, do ordenamento urbano e do patrimônio cultural. Disponível em: <http://www.rkladvocacia.com/livros_artigos-htm\#>. Acesso em: 21 mai. 2008.

MORAES, L. C. S. Curso de direito ambiental. São Paulo: Atlas, 2006.

MOURA, P. C. de. São Paulo de outrora: evocações da metrópole. São Paulo: EDUSP, 1980.

MUKAI, T. Temas atuais de direito urbanístico e ambiental. Belo Horizonte: Fórum, 2004. 
MUMFORD, L. A cidade na história: suas origens, transformações e perspectivas. São Paulo: Martins Fontes, 1982.

MUSEU AFRO BRASIL. O pavilhão: história. Disponível em: <http://www.museuafrobrasil.com.br/pavilhao.asp $>$. Acesso em: 29 jun. 2008.

NOGUEIRA, M. A. Um Estado para a sociedade civil: temas éticos e políticos da gestão democrática. São Paulo: Cortez, 2005.

NOVAK, D. J.; DWYER, J. F.; CHILDS, G. Los beneficios y costos del enverdecimiento urbano. In: KRISHNAMURTHY, L.; NASCIMENTO,

J. R. (Editores). Áreas verdes urbanas em Latinoamérica y el Caribe: memoria del Seminario Internacional celebrado em la Ciudad de México, del 2 al 5 de diciembre de 1996. Chapingo, México: Universidad Autônoma Chapingo, 1998, p.17-38.

NUCCI, J. C. Qualidade ambiental e adensamento urbano: um estudo de ecologia e planejamento da paisagem aplicado ao distrito de Santa Cecília (MSP). Curitiba: O Autor, 2008.

NUEVAS tendências em parques urbanos. Plataforma Urbana, 13 abr. 2006. Disponivel em: $\quad$ http://www.plataformaurbana.cl/archive/2006/04/13/nuevastendencias-en-parques-urbanos/>. Acesso em: 07 ago. 2008.

OHLWEILER, L. Direito administrativo em perspectiva: os termos indeterminados à luz da hermenêutica. Porto Alegre: Livraria do Advogado, 2000.

OLIVA, J. T. A cidade como ator social: a força da urbanidade. In: CARLOS, A. F. A. e LEMOS, A. I. G. Dilemas urbanos: novas abordagens sobre a cidade. São Paulo: Contexto, 2005, p.73-78.

OLIVEIRA, F L de. Projetos para o parque do Ibirapuera: de Manequinho Lopes a Niemeyer (1926-1954). 2003. 370p. Dissertação (Mestrado em Arquitetura e 
Urbanismo) - Escola de Engenharia de São Carlos, Universidade de São Paulo, São Carlos.

OLIVEIRA, F. de P. M. de O.; GUIMARÃES, F. R. Direito, meio ambiente e cidadania: uma abordagem interdisciplinar. São Paulo: Madras, 2004.

OLIVEN, R. G. Urbanização e mudança social no Brasil. Petrópolis: Vozes, 1984.

OZEKI, J. H.; ESTEVAM, A. R. A fluvialidade em rios paulistas. In: COSTA, L. M. S. A. (Org.). Rios e paisagens urbanas em cidades brasileiras. Rio de Janeiro: Viana \& Mosley: PROURB, 2006, p.77-94.

PACHECO, J. A. de Assis. Perdizes: história de um bairro. São Paulo: Secretaria Municipal de Cultura, 2003.

PÁDUA, M. T. J. Análise crítica da nova lei do Sistema Nacional de Unidades de Conservação da natureza do Brasil. Revista de Direito Ambiental, v.22, p.55-61, 2001.

PAULINO, W. R. Ecologia atual. São Paulo: Ática, 1991.

PHILIPPI JR., A.; BRUNA, G. C.; SILVEIRA, V. F. Planejamento territorial: instrumentos de intervenção. In: PHILIPPI JR., A. (Editor). Saneamento, saúde e ambiente: fundamentos para um desenvolvimento sustentável. Barueri-SP: Manole, 2005 , p.623-662.

PHILIPPI JR., A.; MALHEIROS, T. F. Saneamento e saúde pública: integrando homem e ambiente. In: PHILIPPI JR., A (Editor). Saneamento, saúde e ambiente: fundamentos para um desenvolvimento sustentável. Barueri: Manole, 2005, p.03-32.

PIAUí. Governo do estado. Disponível em: $<$ http://www.pi.gov.br/materiaphp?id=10575>. Acesso em: 15 mai. 2008. 
PICO DO JARAGUÁ. Histórico. - Disponível em: $<$ http://www.picodojaragua.com.br/historico.html $>$. Acesso em 13 ago. 2008.

PINTO, A. C. B. Turismo e meio ambiente: aspectos jurídicos. Campinas, Papirus, 1998.

PINTO, A. M. A cidade de São Paulo em 1900. São Paulo: Governo do Estado, 1979.

PONCIANO, L. Bairros paulistanos de A a Z. São Paulo: SENAC, 2001.

PORTO, A. R. História da cidade de São Paulo através de suas ruas. São Paulo: Carthago, 1996.

PORTO ALEGRE. Projeto de lei complementar 005/2007. Institui o sistema municipal de conservação da natureza de Porto Alegre (SMUC-POA). Disponível em: <http://www.camarapoa-rs.gov.br/projeto/040792007PLCE.pdf>. Acesso em: 31 mai. 2008.

PRADO, F. A administração Fábio Prado na prefeitura de São Paulo: através de entrevista concedida a O Estado de S. Paulo. São Paulo: Departamento de Cultura, 1936.

PREFEITURA DA CIDADE DE SÃO PAULO. A bacia. Disponível em: $<$ http://www.prefeitura.sp.gov.br/guarapiranga/abacia_02.asp $>$. Acesso em 21 ago. 2008.

PREFEITURA MUNICIPAL DE SÃO PAULO. Ibirapuera ganha auditório 50 anos depois, 13 dez. 2004. Disponível em: $<$ http://www.prefeitura.sp.gov.br/portal/a_cidade/noticias/index.php? $\mathrm{p}=1062>$. Acesso em: 30 jun. 2008. 
RAMSAR CONVENTION ON WETLANDS. Disponível em: <http://www.ramsar.org/about brazil_p.htm>. Acesso em: 15 fev. 2008.

REALE, E. Brás, Pinheiros, Jardins: três bairros, três mundos. São Paulo: Pioneira; Edusp, 1982.

REIS FILHO, N. G. (Coord.). Guia dos bens tombados: São Paulo. Rio de Janeiro: Expressão e Cultura, 1982.

REVISTA CALOR. Disponível em: <www.revistacalor.com.br/verpiaui.php?id-72>. Acesso em: 15 mai. 2008.

REVISTA ENGENHARIA. Justiça e engenharia caminham juntas. Disponível em: $<\underline{\text { http: } / / \text { www.engenhoeditora.com.br/memoriaeng } 547 . \mathrm{htm}}>$. Acesso em: 23 jun. 2008.

REZEK, J. F. Direito internacional público: curso elementar. São Paulo: Saraiva, 1991.

RIBEIRO, M. A. Ecologizar: pensando a ambiente humane. Belo Horizonte: Rona, 2000 .

RIBEIRO, J. B. Proposta de um roteiro metodológico para criação de reservas particulares do patrimônio natural municipais e elaboração de plano de manejo e conservação em Curitiba, Paraná. 2008. 29p. Monografia (MBA em Gestão Ambiental) - Departamento de Economia Rural e Extensão, Setor de Ciências Agrárias, Universidade Federal do Paraná, Curitiba.

RICHTER, R. A. Meio ambiente cultural: omissão do Estado e tutela judicial. Curitiba: Juruá, 1999.

RIO, J. P. do. Relatório de 1927, apresentado pelo Dr. J. Pires do Rio, prefeito do município de São Paulo. São Paulo: Empresa Gráfica Limitada, 1928. 
RIO GRANDE DO NORTE. Lei Complementar 272, de 03 de março de 2004. Dispõe sobre a política e o sistema estadual do meio ambiente. Disponível em: <http://www.m.gov.br/secretaria/idema/272.html>. Acesso em: 11 mai 2008.

RIO GRANDE DO SUL. Lei 9.519, de 21 de janeiro de 1992. Institui o código florestal do Rio Grande do Sul. Disponível em: <http://www.sema.rs.gov.br/sema/htm/lei 9519.htm>. Acesso em: 11 mai 2008.

RIO GRANDE DO SUL. Decreto 34.256, de 02 de abril de 1992. Cria o sistema estadual de unidades de conservação. Disponível em: $<$ http://www.sema.rs.gov.br/sema/html/dec 34256.htm>. Acesso em: 11 mai. 2008.

RIO GRANDE DO SUL. Decreto 38.814, de 26 de agosto de 1998. Disponível em: $<$ http://www.sema.rs.gov.br/sema/html/dec 38814.htm>. Acesso em: 11 mai. 2008.

RIO GRANDE DO SUL. Decreto 39.414, de 15 de abril de 1999. Dá nova redação ao artigo 12 do Decreto 38.814, de 26 de agosto de 1998. Disponível em: $<$ http://www.sema.rs.gov.br/sema/html/dec 39414.htm>. Acesso em: 11 mai. 2008.

ROBBA, F.; MACEDO, S. S. Praças brasileiras. São Paulo: Edusp; Imprensa Oficial, 2002.

ROCCO, R. Estudo de impacto de vizinhança. Rio de Janeiro: Lumen Júris, 2006.

RODRIGUES, J. E. R. Aspectos jurídicos das unidades de conservação. Revista de Direito Ambiental, v.1, p.107-141, 1996.

RODRIGUES, J. E. R. A evolução da proteção do patrimônio cultural: crimes contra o ordenamento urbano e o patrimônio cultural. In: FIGUEIREDO, G. J. P. (Org.). Temas de direito ambiental e urbanístico. São Paulo: Max Limonad, 1998, p.199225. 
RODRIGUES, J. E. R. Sistema nacional de unidades de conservação (SNUC) (Lei 9.985 de 18 de julho de 2000). In: MORAES, R. J. et al. (Coords.). As leis federais mais importantes de proteção ao meio ambiente comentadas. Rio de Janeiro: Renovar, 2005a, p.333-346.

RODRIGUES, J. E. R. Sistema nacional de unidades de conservação. São Paulo: Revista dos Tribunais, $2005 b$.

RODRIGUES, J. E. R.; BENNATI, P.P.; O ozônio e a poluição do ar:aspectos técnicos, juridicos e políticos, Revista de Direito Ambiental, v.22, p.147-160, 2001.

RODRIGUES, M. A. Processo civil ambiental. São Paulo: Revista dos Tribunais, 2008.

ROLNIK, R. O que é cidade? São Paulo: Brasiliense, 2004.

RONDÔNIA. Lei 11.144, de 12 de dezembro de 2002. Dispõe sobre o sistema estadual de unidades de conservação da natureza - SEUC/RO. Disponível em: <http://www.sedam.ro.gov.br/web/guest/Instituicao/Legislacao/LeiEstadual>. Acesso em: 11 mai. 2008.

ROSS, D. La faune, la flore et les parcs sauvages em milieu urbain. Disponivel em: $<$ http://adp.lin.ca/resource//HTML/CPRA vol47no1 1989/vm133-f.pdf $>$. Acesso em: 12 jul. 2008.

SAINT-HILAIRE, A. de. Viagem à província de São Paulo. Belo Horizonte: Itatiaia; São Paulo: Edusp, 1976.

SANT'ANNA, N. São Paulo histórico. São Paulo, Departamento de Cultura de São Paulo, 1939.

SANTA CATARINA. Lei 11.986 , de 12 de novembro de 2001. Institui o sistema estadual de unidades de conservação da natureza. Disponivel em: 
$<$ http://www.mp.sc.gov.br/portal/site/portal/portal_lista.asp?secao id=811 $>$. Acesso em: 11 mai. 2008.

SANTOS, A. M..; MOTTA, A. Desafios para a sustentabilidade no espaço urbano brasileiro. In: GRAZIA, G de; QUEIROZ L. L.; MOTTA, A.; SANTOS, A. M. O desafio da sustentabilidade urbana. Rio de Janeiro: FASE/BASE, 2001, p. 83-111.

SANTOS, E. S. Reflexões sobre a utilização de espaços públicos para o lazer esportivo. Revista Ra'e'ga, n 11, p.25-33, Curitiba: 2006.

SANTOS, M. A urbanização brasileira. São Paulo: EDUSP, 2005.

SANTOS, S. H. Direito ambiental: unidades de conservação, limitações administrativas. Curitiba: Juruá, 2000.

SÃO PAUlO (Estado). Ginásio do Ibirapuera. Disponível em:

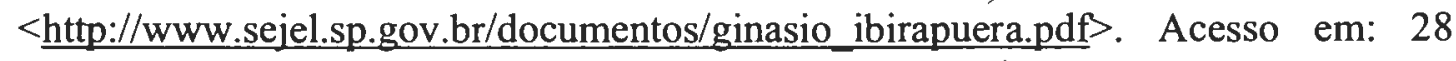
jun. 2008.

SÃO PAULO (Estado). Decreto 6.082 de 14 de setembro de 1933. Aprova a planta e discrimina os limites dos terrenos reservados ao Instituto Biológico de Defesa Agrícola e Animal, na área pertencente ao estado na invernada dos bombeiros, nesta Capital. Coleção das Leis e Decretos do Estado de S. Paulo, São Paulo, tomo XLIII, p.827-828, 1933.

SÃO PAULO (Estado). Secretaria do Meio Ambiente. Atlas das unidades de conservação do Estado de São Paulo. São Paulo: 2001.

SÃo PAULO (Município). Anais da Câmara Municipal de São Paulo: 1887. São Paulo: Espindola, 1907.

SÃO PAULO (Município). Anais da Câmara Municipal de São Paulo: 1919. São Paulo: Piratininga, 1919. 
SÃO PAULO (Município). Anais da Câmara Municipal de São Paulo: 1923. São Paulo: Piratininga, 1923.

SÃo PAUlO (Municipio). Anais da Câmara Municipal de São Paulo: 1924. São Paulo: Escolas Profissionais Salesianas, 1924.

SÃo PAUlO (Município). Anais da Câmara Municipal de São Paulo: 1925. São Paulo: Ferrari \& Losasso, 1925.

SÃo PAUlO (Município). Anais da Câmara Municipal de São Paulo: 1926. São Paulo: Ferrari \& Losasso, 1926.

SÃO PAULO (Município). Atlas ambiental do município de São Paulo: o verde, o território, o ser humano: diagnóstico e bases para a definição de políticas públicas para as áreas verdes no Município de São Paulo. São Paulo: SVMA, 2004.

SÃO PAULO (Município). Lei 10.430, de 13 de setembro de 2001. Plano diretor estratégico do Município de São Paulo. Diário Oficial do Município de São Paulo, São Paulo, São Paulo, 19 set. 2002, suplemento, p.01-104.

SÃO PAULO (Município) Lei 13.539, de 20 de março de 2003. Dispõe sobre a criação dos Conselhos Gestores dos Parques Municipais. Disponível em: $<$ http://portal.prefeitura.sp.gpv.br/secretarias/seguranca_urbana/guarda_civil/legislac ao/leis/0026>. Acesso em: 17 set. 2008.

SÃO PAULOa (Município). Secretaria do verde e do meio ambiente. Disponivel em: $<$ http://www.prodam.sp.gov.br/svma/parques/aclimação/index.htm $>$. Acesso em: 5 mai. 2008.

SÃO PAULOb (Município). Secretaria do verde e do meio ambiente. Disponível em:

$<$ http://www.prodam.sp.gov.br/svma/parques/ibirapuera/index.htm $>$. Acesso em: 5 mai. 2008. 
SÃO PAAULOc (Município). Secretaria do verde e do meio ambiente. Disponível em: $<$ http://www.prodam.sp.gov.br/svma/parques/luz/index.htm $>$. Acesso em: 5 mai. 2008.

SÃO PAULOd (Município). Secretaria do verde e do meio ambiente. Disponível em: $<$ http://www.prodam.sp.gov.br/svma/parques/siqueira campos/index.htm $>$. Acesso em: 5 mai. 2008.

SÃO PAULOe (Município). Aspectos históricos e culturais dos viveiros municipais. Disponível em:

$<$ http://portal.prefeitura.sp.gov.br/secretarias/meio ambiente/fauna flora/viveiros/00 02> Acesso em: 22 jun. 2008.

SÃO PAULOf (Município). Planetários de São Paulo. Disponível em:

$<$ http://www2.prefeitura.sp.gov.br/secretarias/meio_ambiente/planetarios/planetarios sao paulo/0003 >. Acesso em: 28 jun. 2008.

SARTI, A. C. Reflexões conceituais para a delimitação de um parque urbano para Rio Claro (SP). HOLOS Environment, v.2, nº 1, p.138-155, 2002.

SCALISE, W. Parques urbanos: evolução, projeto; funções e usos. Revista Assentamentos Humanos, v.4, nº 1, p.17-24, Marília: 2002.

SCARLATO, F. C. População e urbanização brasileira. In: ROSS, J. L. S. (Org.). Geografia do Brasil. São Paulo: Edusp, 2001, p.381-464.

SEBRAE.

$<$ http://www.df.sebrae.com.br/Downloads/ambiental/Questoes\%20Ambiental\%20DF .pdf $>$. Acesso em: 15 mai. 2008. 
SECRETARIA DA JUSTIÇA. Parque do Belém ganha espaço ecumênico.

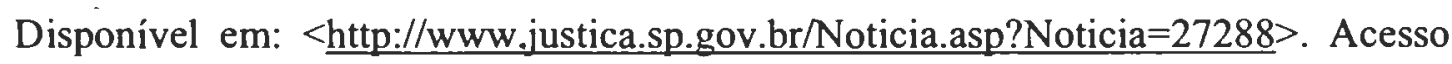
em: 31 ago. 2008.

SECRETARIA DA JUVENTUDE, ESPORTE E LAZER. Parque da Juventude. Disponível em: <http://www.sejl.sp.gov.br/parquedajuventude/>. Acesso em 31 ago. 2008.

SEGAWA, H. Ao amor ao público: jardins no Brasil. São Paulo: Nobel; Fapesp, 1996.

SEIXAL. Postura municipal sobre espaços verdes, parques urbanos e jardins. Disponível em: <http://www.cm.seixal.pt/NR/rdonlyres/2BBE4B42-D2B1-4A3F87FE-GE9765F80267/362/post verdes.pdf>. Acesso em: 12 jul. 2008.

SEMPLA (Org.). Plano diretor estratégico do Município de São Paulo. São Paulo: SENAC; Prefeitura Municipal de São Paulo, 2004.

SERGIPE. Lei 5.858, de 22 de março de 2006. Dispõe sobre a política estadual do meio ambiente e institui o sistema estadual de meio ambiente. Disponível em:

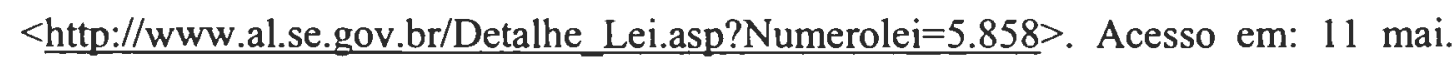
2008.

SERPA, A. O espaço público na cidade contemporânea. São Paulo: Contexto, 2007.

SESSO JÚNIOR. G. Retalhos da velha São Paulo. São Paulo: OESP; Maltese, 1986.

SILVA, C. H. D. da. Plano diretor: teoria e prática. São Paulo: Saraiva, 2008.

SILVA, J. A. da. Direito urbanístico brasileiro. São Paulo: Malheiros, 2006.

SILVA, J. A. da. Aplicabilidade das normas constitucionais. São Paulo: Malheiros, $2007 \mathrm{a}$. 
SILVA, J. A. da. Direito ambiental constitucional. São Paulo: Malheiros, 2007b.

SILVA, M. V. A idéia do meio ambiente urbano: a biologização das cidades. In: GITAHY, M. L. C.; LIRA, J. T. C. (Orgs.). Tempo, cidade e arquitetura. São Paulo: FAU; Annablume, 2007, p.64-71.

SILVEIRA, C. J. da; SOUZA, P. B. Exigências para uma gestão urbano-ambiental sustentável. In: COUTINHO, R.; BONIZZATO, L. (Coords.). Direito da cidade: novas concepções sobre as relações jurídicas no espaço social urbano. Rio de Janeiro: 2007, p.165-178.

SILVEIRA, R. da S. Cidade e lazer em São Paulo. 2003. 109p. Dissertação (Mestrado em Geografia) - Faculdade de Filosofia e Ciências Humanas, Universidade de São Paulo, São Paulo.

SIQUEIRA JR., P. H.; OLIVEIRA, M. A. M. Direitos humanos e cidadania. São Paulo: Revista dos Tribunais, 2007.

SIRVINSKAS, L. P., Manual de direito ambiental. São Paulo: Saraiva, 2008.

STTE, C. A construção das cidades segundo seus princípios artísticos. São Paulo: Ática, 1992.

SOARES, G. F. S. Direito internacional do meio ambiente: emergência, obrigações e responsabilidades. São Paulo: Atlas, 2001.

SOCIEDADE AMIGOS DA CIDADE. São Paulo: cidade sem parques e sem áreas livres. São Paulo: Sociedade Amigos da Cidade, n 08, mai. 1950.

SOCIEDADE MUNDIAL DE PROTEÇÃO ANIMAL. Lei 10.431, de 10 de dezembro de 2006. Dispõe sobre a política de meio ambiente e de proteção à biodiversidade do Estado da Bahia. Disponível em: 
$<$ http://www.bdlegislacao.com.br/banco/index.php?option=com content\&task=view $\underline{\& \mathrm{id}=117>}$. Acesso em: 11 mai. 2008.

SOUZA, M. L. O desafio metropolitano: um estudo sobre a problemática sócioespacial nas metrópoles brasileiras. Rio de Janeiro: Bertrand Brasil, 2000.

SOUZA, P. R. P. de. O direito ambiental e a construção do direito sustentável. In: PAULA, J. L. M. de. (Coord.). Direito ambiental e cidadania. Leme-SP: JH Mizuno, 2007, p.157-200.

SP desapropria terreno para o Parque da Aclimação. Economia: último minuto, 29 mai. 2008. Disponível em: $<$ http://ultimosegundo.ig.com.br/economia/2008/04/29/sp_desapropria_terreno para _o_parque_da_aclimacao_1291483html-16k > . Acesso em: 21 mai. 2008.

SVMA; IPT. GEO cidade de São Paulo: panorama do meio ambiente urbano. Brasília: PNUMA, 2004.

TAYLOR, B. Jardins urbanos da América. Disponivel em: <http://www.taps.org.br/Paginas/estiloartigo09.html>. Acesso em: 10 jul 2006.

TOCANTINS. Lei 1.560 , de 05 de abril de 2005. Institui o sistema estadual de unidades de conservação da natureza. Disponivel em: $<$ http://www.al.to.gov.br/legislacao.swd?op=vr\&codigo $=17326 \&$ numero $=1560 \&$ ano $\underline{=2005}>$. Acesso em: 11 mai 2008 .

TOLEDO, R. F. de; PELICIONI, M. C. F. Educação ambiental em unidades de conservação. In: PHILIPPI JR., A; PELICIONI, M. C. F. (Editores). Educação ambiental e sustentabilidade. Barueri-SP: Manole, 2005, p.749-770.

TORRES, M. C. T. M. Ibirapuera. São Paulo: Departamento do Patrimônio Histórico, 1977. 
UMA guerra pelos canais santistas. Disponível em: $<$ http://www.novomilenio.inf.br/santos/hoo76a.htm>. Acesso em: 8 mai. 2008.

UNESCO. Global network of national geoparks. Disponível em: <http://www.unesco.org/science/earth/geoparks.shtml $>$. Acesso em: 29 abr 2008.

UNESCO BRASIL. Chapada do Araripe torna-se o primeiro geoparque do hemisfério sul. Disponivel em: $<$ http://www.unesco.org.br/noticias/ultimas/araripe/oticias view $>$. Acesso em: 29 abr. 2008.

VARGAS, H. C.; RIBEIRO H. Qualidade ambiental urbana: ensaio de uma definição. In: VARGAS, H. C.; RIBEIRO, H. (Orgs.).Novos instrumentos de gestão ambiental urbana. São Paulo: EDUSP, 2001.

VERDE da cidade tem mais cem mil metros. O Estado de S. Paulo, São Paulo, 20 set. 1979.

VIAGEM no tempo. Disponivel em: $<$ http://playcenteruau.blogspot.com/2008/06/viagem-no-tempo.html $>$. Acesso em: 09 jul. 2008.

VIEIRA, J. de S. R. Cidades sustentáveis. In: MOTA, M. (Coord.). Fundamentos teóricos do direito ambiental. Rio de Janeiro: Elsevier, 2008, p.313-344

VIEIRA, P. B. de H. Uma visão geográfica das áreas verdes de Florianópolis, SC: estudo de caso do parque ecológico do Córrego Grande (PECG). 2004. 107p. Monografia de conclusão de Curso (Graduação em Geografia) - Centro de Filosofia e Ciências Humanas, Universidade Federal de Santa Catarina, Florianópolis.

VIZZOTTO, A. T. A privatização do espaço público. In: PRESTES, V. B. (Org.). Temas de direito urbano-ambiental. Belo Horizonte: Fórum, 2006, p.171-192. 
WALKER, C. The public value of urban parks. Disponível em: $<$ http://www.urban.org/publications/311011.html >. Acesso em 12 jul. 2008.

WALKER, J. R. (Coord.). O presépio napolitano em São Paulo. São Paulo: Retrato Publicitário, 2002.

WORLD WILDLIFE FUND. Disponível em: <http://www.wwf.org.br/natureza_brasileira/meio_ambiente_brasil/mata_atlantica/m ata_atlantica_acoes resultados/solucaomatal/programa_sitios_do patrimonio_mund ial natural/index.cfm>. Acesso em: 15 fev. 2008.

YOSHIDA, C. Y. M. Jurisdição e competênciá em matéria ambiental. In: MARQUES, J. R. (Org.). Leituras complementares de direito ambiental. Salvador: Podivm, 2008, p.29-55.

ZAMORA, E. C.; POMBO, E. S.; BRASSART, C. 'S.; MORENCOS, I, Z. Metodologia para el estudio de los parques urbanos: la Comunidad de Madrid. Revista Internacional de Ciencia y Tecnologia de la Información Geográfica, Madrid, n 03, p.160-185, 2003. 